\title{
Enantioselective Synthesis of Diaryl Sulfoxides Enabled by Molecular Recognition
}

Finn Burg, ${ }^{\dagger}$ Christoph Buchelt, ${ }^{\dagger}$ Nora M. Kreienborg, ${ }^{\ddagger}$ Christian Merten, ${ }^{\ddagger}$ and Thorsten Bach $^{*+}$

${ }^{\dagger}$ Department Chemie and Catalysis Research Center (CRC), Technische Universität München, 85747 Garching, Germany.

‡Fakultät für Chemie und Biochemie, Ruhr-Universität Bochum, Universitätsstraße 150, 44801 Bochum, Germany

Corresponding Author

*E-mail: thorsten.bach@ch.tum.de. 
2. Chemical syntheses $\quad 5$

2.1. General procedure 1 (GP1): synthesis of sulfides 7 from 2-quinolones 5

2.2. General procedure 2 (GP2): synthesis of sulfides 7 from 2-bromoquinolone SI-2 9

\begin{tabular}{lr} 
2.3. & Single procedures \\
\hline
\end{tabular}

2.4. Optimization of the enantioselective sulfoxidation with sulfide 7a 18

2.5. General procedure 3 (GP3): enantioselective sulfoxidation of sulfides $7 \quad 20$

2.6. Derivatization of the optically enriched sulfoxide $8 a$

3.
3. Analytical data

3.1. ${ }^{1} \mathrm{H}$ and ${ }^{13} \mathrm{C}$ spectra of new compounds $\quad 39$

$\begin{array}{lr}\text { 3.2. HPLC traces } & 90\end{array}$

$\begin{array}{lr}\text { 4. ECD spectroscopic analysis } & 115\end{array}$

4.1. Absolute configuration of compound 8I via ECD spectroscopy 115

\begin{tabular}{ll} 
4.2. & Cartesian coordinates of 8I-c1 and -c2 \\
\hline
\end{tabular}

$\begin{array}{lr}\text { 5. Abbreviations } & 117\end{array}$

\begin{tabular}{lr} 
6. & References \\
\hline
\end{tabular} 


\section{General experimental procedure}

All experiments were performed in flame-dried glassware under an argon atmosphere and under anhydrous conditions using Schlenk techniques.

Solvents and reagents: Dry dichloromethane $\left(\mathrm{CH}_{2} \mathrm{Cl}_{2}\right)$ and tetrahydrofuran (THF) were obtained from an MBraun MB-SPS 800 solvent purification system. Dry benzene (PhH), dimethylformamide (DMF), 1,4-dioxane and methanol (MeOH) were obtained from either Sigma-Aldrich or Acros in the highest available purity $(>99 \%$, extra dry over molecular sieves) and used without further purification. Technical solvents used for aqueous workup and purification by column chromatography [acetone, dichloromethane $\left(\mathrm{CH}_{2} \mathrm{Cl}_{2}\right)$, diethyl ether $\left(\mathrm{Et}_{2} \mathrm{O}\right)$, ethyl acetate (EtOAc), hexane, methanol $(\mathrm{MeOH})$, pentane] were distilled prior to use. Commercially available chemicals were obtained from Acros Organics, Ambeed, AlfaAesar, ABCR, Chemical Co., Chempur, Combi-Blocks, Sigma Aldrich, StremChemicals and TCl Europe and used as received unless otherwise stated. lodosobenzene (PhIO), ${ }^{1}$ as well as the chiral manganese porphyrin complex $5^{2}$ were synthesized according to procedures previously described in literature. PhIO was stored at $-20^{\circ} \mathrm{C}$ under argon. 6-Methylquinolone and 7methylquinolone were obtained following procedures previously disclosed by our group. ${ }^{3}$

Chromatography: Thin layer chromatography (TLC) was performed on pre-coated glass-backed Merck Kieselgel $60 \mathrm{~F}_{254}$ plates with visualization effected with ultra-violet irradiation $(\lambda=254,366 \mathrm{~nm})$ and/or staining using potassium permanganate $\left(\mathrm{KMnO}_{4}\right)$ solution prepared from potassium permanganate $(3.00 \mathrm{~g})$, potassium carbonate $(20.0 \mathrm{~g})$ and $5 \%$ aqueous sodium hydroxide solution $(5.00 \mathrm{~mL})$ in water $(300 \mathrm{~mL})$. Flash column chromatography was performed on silica 60 (Merck, 230-400 mesh) with the indicated eluent mixtures. Automated flash column chromatography was performed on a Büchi C-815 Flash chromatography instrument for purification of all products of the enantioselective sulfoxidation reaction. In all cases, Biotage ${ }^{\circledR}$ pre-packed silica cartridges (Biotage ${ }^{\circledR}$ Sfär Silica D Duo $60 \mu \mathrm{m} 10 \mathrm{~g}$, manufacturer number FSRD-0445-0010) were used in combination with the following method ( $\mathrm{CV}=$ column volumes): $\mathrm{EtOAC} / \mathrm{CH}_{2} \mathrm{Cl}_{2}$ solvent mixture, flow rate $30 \mathrm{~mL} / \mathrm{min}, 10 \%$ [3 CVs], $10 \% \rightarrow 20 \%$ [3 CVs], 20\% [4 CVs], 20\% $\rightarrow 30 \%$ [ $2 \mathrm{CVs}$ ], 30\% [5 CVs], 30\% $\rightarrow 50 \%$ [2 CVs], $50 \%$ [2 CVs], 100\% [3 CVs], UV detection at $280 \mathrm{~nm}$.

Melting points: Determined using a Kofler heating bar designed by L. Kofler (Reichert) without correction or using a Büchi M-510 melting point apparatus, with range quoted to the nearest whole number.

Infrared Spectroscopy: Spectra were recorded on a Perkin Elmer Frontier Optica+SP10 spectrometer by ATR technique. The signal intensity is assigned using the following abbreviations: vs (very strong), s (strong), $\mathrm{m}$ (medium), w (weak).

NMR spectroscopy: ${ }^{1} \mathrm{H}$ NMR spectra were recorded on Bruker AVHD-300, AVHD-400 or AVHD-500 spectrometers at $303 \mathrm{~K}$ operating at $300 \mathrm{MHz}, 400 \mathrm{MHz}$ and $500 \mathrm{MHz}$, respectively. Data is reported in the following manner: chemical shift [in parts per million (ppm) relative to residual $\mathrm{CHCl}_{3}\left(\delta_{H}=7.26 \mathrm{ppm}\right), \mathrm{MeOD}-d_{3}\left(\delta_{H}=3.31 \mathrm{ppm}\right)$ or DMSO- $\left.d_{5}\left(\delta_{\mathrm{H}}=2.50 \mathrm{ppm}\right)\right]$, number of protons, multiplicity and coupling constant $J$ (measured in $\mathrm{Hz}$ to the nearest $0.1 \mathrm{~Hz}$ ). The multiplicity of a signal is indicated as: s-singlet, bs-broad singlet, $d$-doublet, t-triplet, qquartet, hept-heptet, m-multiplet, or combinations of these. Apparent multiplets which occur as a result of 
coupling constant equality between magnetically non-equivalent protons are marked as virtual (virt). ${ }^{13} \mathrm{C} \mathrm{NMR}$ spectra were recorded on a AVHD-400 or AVHD-500 spectrometers at $303 \mathrm{~K}$ operating at $101 \mathrm{MHz}$ and $126 \mathrm{MHz}$ respectively with proton decoupling. The chemical shift [in parts per million (ppm)] is reported relative to residual $\mathrm{CHCl}_{3}\left(\delta_{\mathrm{C}}=77.16 \mathrm{ppm}\right), \mathrm{MeOD}-d_{3}\left(\delta_{\mathrm{C}}=49.00 \mathrm{ppm}\right)$ or DMSO- $d_{5}\left(\delta_{\mathrm{C}}=39.52 \mathrm{ppm}\right) .{ }^{19} \mathrm{~F} \mathrm{NMR}$ spectra were recorded on a Bruker AVHD-400 or AVHD-500 spectrometers at $303 \mathrm{~K}$ operating at $376 \mathrm{MHz}$ and $476 \mathrm{MHz}$ and are given without reference. Spectra are reported based on appearance, not on theoretical multiplicities derived from structural information.

Mass Spectroscopy (ESI): High-resolution mass spectra (HRMS) were recorded on a Thermo Finnigan LTQ FT (HRMS-ESI) with each value obtained within 5 ppm of the calculated mass.

Specific rotations: Optical rotations were determined using a Bellingham+Stanley ADP440+ polarimeter with a $0.5 \mathrm{~cm}$ cuvette at $\lambda=589 \mathrm{~nm}$ (Na-D-line) at $303 \mathrm{~K}$. Specific rotation is reported as followed: $[\alpha]_{\mathrm{D}}^{\top}$ in $10^{-1} \mathrm{grad} \mathrm{cm}^{2}$ $\mathrm{g}^{-1}$ (c was defined as g per $100 \mathrm{~mL}$ solvent).

Chiral HPLC: Analytical HPLC (Thermo Fisher, Dionex Ultimate 3000 pump, Dionex Ultimate 3000, LPG 3400SD Pump, WPS3000SL Autosampler, DAD 3000 photodiode array detector) was performed using different chiral stationary phases (Daicel ChiralCel, Chemical Industries, flow rate, type and eluent is given for the corresponding compounds) and UV detection ( $\lambda=210$ or $254 \mathrm{~nm}$ ) at $303 \mathrm{~K}$. Racemic samples rac-8 were prepared as following: $\mathrm{H}_{2} \mathrm{O}_{2}$ (30\% in $\mathrm{H}_{2} \mathrm{O}, 9.8 \mathrm{M}, 21.4 \mu \mathrm{mol}, 2.1$ equiv) was added to a vigorously stirring mixture of the corresponding sulfide 7 (100 $\mu \mathrm{mol}, 1.0$ equiv) in HFIP (500 $\mu \mathrm{L}, 0.2 \mathrm{M})$. The reaction mixture was stirred for $2 \mathrm{~h}$ at $23^{\circ} \mathrm{C}$ at which point the reaction progress was monitored by $\operatorname{TLC}\left(20 \%\right.$ acetone $/ \mathrm{CH}_{2} \mathrm{Cl}_{2}$, UV detection). Additional portions of $\mathrm{H}_{2} \mathrm{O}_{2}$ (30\% in $\mathrm{H}_{2} \mathrm{O}, 21.4 \mu \mathrm{mol}, 2.1$ equiv) were added every $2 \mathrm{~h}$ until the starting material was completely converted to a considerably more polar compound (typically $\Delta R_{f}>0.4$ ). The solvent was evaporated by a gentle pressurized stream of air and the crude material was subjected to automated FCC (vide supra) to yield the entitled sulfoxide rac-8. 


\section{Chemical syntheses}

\subsection{General procedure 1 (GP1): synthesis of sulfides 7 from 2-quinolones}

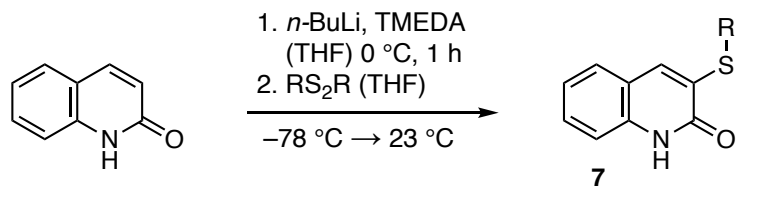

$n$-BuLi (2.5 $\mathrm{M}$ in hexanes, 2.4 equiv) was added dropwise to a suspension of 2-quinolone (1.0 equiv) and TMEDA (3.4 equiv) in THF ( $0.2 \mathrm{M}$ ) at $-78^{\circ} \mathrm{C}$ affording a black solution. The reaction mixture was allowed to warm to $0{ }^{\circ} \mathrm{C}$ and was stirred for $1 \mathrm{~h}$ with external ice bath cooling, before it was cooled to $-78{ }^{\circ} \mathrm{C}$ again. The corresponding disulfide (2.0 equiv) dissolved in THF (1.0 M) was slowly added and the reaction mixture was allowed to warm to ambient temperature over a period of $16 \mathrm{~h}$. The reaction was quenched by addition of sat. aq. $\mathrm{NH}_{4} \mathrm{Cl}$ solution and EtOAc. The organic layer was separated, and the aqueous layer was extracted twice with EtOAc. The combined organic layers were washed with sat. aq. $\mathrm{NaCl}$ solution, dried over $\mathrm{Na}_{2} \mathrm{SO}_{4}$ and the solvent was removed under reduced pressure. The residual crude material was purified by FCC $\left(10 \% \rightarrow 25 \% \mathrm{EtOAc} / \mathrm{CH}_{2} \mathrm{Cl}_{2}\right)$ to yield the entitled sulfide 7 .

\subsubsection{3-(p-Tolylthio)-2-quinolone (7b)}<smiles>Cc1ccc(Sc2cc3ccccc3[nH]c2=O)cc1</smiles>
Following GP1 the entitled sulfide 7b was obtained as an off-white solid (187 mg, $669 \mu \mathrm{mol}$, 47\%).

$\boldsymbol{R}_{\mathrm{f}}\left(30 \% \mathrm{EtOAC} / \mathrm{CH}_{2} \mathrm{Cl}_{2}\right): 0.69$.

${ }^{1} \mathbf{H}$ NMR $\left(500 \mathrm{MHz}, \mathrm{DMSO}-\mathrm{d}_{6}\right) \delta[\mathrm{ppm}]=12.1(\mathrm{bs}, 1 \mathrm{H}, \mathrm{NH}), 7.45\left(\right.$ virt d, $\left.{ }^{3} \mathrm{~J} \approx 8.1 \mathrm{~Hz}, 2 \mathrm{H}, \mathrm{H}-2^{\prime}\right)$, 7.43-7.39 (m, 2H, H-5, H-7), 7.34 (virt d, $\left.{ }^{3} \mathrm{~J} \approx 8.0 \mathrm{~Hz}, 2 \mathrm{H}, \mathrm{H}-3^{\prime}\right), 7.30\left(\mathrm{dd},{ }^{3} \mathrm{~J}=8.1 \mathrm{~Hz},{ }^{4} \mathrm{~J}=1.0 \mathrm{~Hz}, 1 \mathrm{H}, \mathrm{H}-8\right), 7.12-7.07$ (m, 2H, H-4, H-6), $2.38\left(\mathrm{~s}, 3 \mathrm{H}, \mathrm{CH}_{3}\right)$.

${ }^{13} \mathrm{C}$ NMR (126 MHz, DMSO-d $) \delta$ [ppm] = 159.0 (C-2), 139.1 (C-4'), 136.6 (C-8a), 134.5 (C-2'), 133.4 (C-3), 131.7 (C-4), 130.8 (C-3'), 129.2 (C-7), 126.6 (C-5), 126.5 (C-1'), 122.2 (C-6), 119.3 (C-4a), 115.0 (C-8), $20.9\left(\mathrm{CH}_{3}\right)$.

HRMS (+ESI): calc. for $\mathrm{C}_{16} \mathrm{H}_{14} \mathrm{ONS}[\mathrm{M}+\mathrm{H}]^{+}:$268.0791; found: 268.0792 .

IR (ATR) $\tilde{v}\left[\mathrm{~cm}^{-1}\right]=2925(w), 2850(w), 1645$ (vs, C=O), $1603(\mathrm{w}, \mathrm{C}=\mathrm{C}), 1555(\mathrm{w}, \mathrm{C}=\mathrm{C}), 1493(\mathrm{w}), 1261$ (w), 1032 (w), $829\left(w, s p^{2} \mathrm{C}-\mathrm{H}\right), 744\left(\mathrm{w}, \mathrm{sp}^{2} \mathrm{C}-\mathrm{H}\right)$.

m.p. $=256-259^{\circ} \mathrm{C}$. 


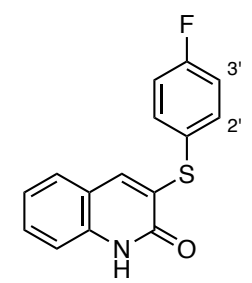

Following GP1 the entitled sulfide 7c was obtained as an off-white solid (178 mg, $656 \mu \mathrm{mol}$, $44 \%)$.

$\boldsymbol{R}_{\mathbf{f}}\left(30 \% \mathrm{EtOAC} / \mathrm{CH}_{2} \mathrm{Cl}_{2}\right): 0.69$.

${ }^{1} \mathrm{H}$ NMR $\left(500 \mathrm{MHz}, \mathrm{DMSO}-d_{6}\right) \delta[\mathrm{ppm}]=12.1$ (bs, $\left.1 \mathrm{H}, \mathrm{NH}\right), 7.62\left(\right.$ virt dd, ${ }^{3} \mathrm{~J} \approx 8.8 \mathrm{~Hz},{ }^{4} \mathrm{JFF}_{\mathrm{HF}} \approx 5.4 \mathrm{~Hz}$, $2 \mathrm{H}, \mathrm{H}-2^{\prime}$ ), $7.48\left(\mathrm{dd},{ }^{3} \mathrm{~J}=7.9 \mathrm{~Hz},{ }^{4} \mathrm{~J}=1.4 \mathrm{~Hz}, 1 \mathrm{H}, \mathrm{H}-5\right.$ ), 7.43 (ddd, ${ }^{3} \mathrm{~J}=8.4,7.1 \mathrm{~Hz},{ }^{4} \mathrm{~J}=1.4 \mathrm{~Hz}, 1 \mathrm{H}, \mathrm{H}-7$ ), 7.37 (virt t, $\left.{ }^{3} \mathrm{~J} \approx{ }^{3} \mathrm{~J}_{\mathrm{HF}}=8.8 \mathrm{~Hz}, 2 \mathrm{H}, \mathrm{H}-3^{\prime}\right), 7.31\left(\mathrm{dd},{ }^{3} \mathrm{~J}=8.3 \mathrm{~Hz},{ }^{4} \mathrm{~J}=1.0 \mathrm{~Hz}, 1 \mathrm{H}, \mathrm{H}-8\right), 7.14(\mathrm{~s}, 1 \mathrm{H}, \mathrm{H}-4), 7.11$ (ddd, ${ }^{3} \mathrm{~J}=8.1,7.1 \mathrm{~Hz}$, $\left.{ }^{4} J=1.2 \mathrm{~Hz}, 1 \mathrm{H}, \mathrm{H}-6\right)$.

${ }^{13} \mathrm{C}$ NMR $\left(126 \mathrm{MHz}, \mathrm{DMSO}-\mathrm{d}_{6}\right) \delta[\mathrm{ppm}]=162.7\left(\mathrm{~d},{ }^{1} \mathrm{~J}_{\mathrm{CF}}=247.0, \mathrm{C}-4^{\prime}\right), 159.0(\mathrm{C}-2), 136.8\left(\mathrm{~d},{ }^{3} J_{\mathrm{CF}}=8.6, \mathrm{C}-2^{\prime}\right), 136.7$ (C-8a), 132.9 (C-4), 132.4 (C-3), 129.4 (C-7), 126.8 (C-5), 125.9 (d, $\left.{ }^{4} J_{C F}=3.4, C-1^{\prime}\right), 122.2$ (C-6), 119.3 (C-4a), 117.3 $\left(d,{ }^{2} J_{C F}=21.8, C-3^{\prime}\right), 115.0(C-8)$.

${ }^{19} \mathrm{~F}$ NMR $\left(376 \mathrm{MHz}, \mathrm{DMSO}-d_{6}\right) \delta[\mathrm{ppm}]=-112.0\left(\mathrm{tt},{ }^{3} \mathrm{~J}=8.9 \mathrm{~Hz},{ }^{4} \mathrm{~J}=5.4 \mathrm{~Hz}, 1 \mathrm{~F}\right)$.

HRMS (+ESI): calc. for $\mathrm{C}_{15} \mathrm{H}_{11}$ OFNS [M+H] $]^{+}$:272.0540; found: 272.0541 .

IR (ATR) $\tilde{v}\left[\mathrm{~cm}^{-1}\right]=3150(\mathrm{w}, \mathrm{N}-\mathrm{H}), 2927(\mathrm{w}), 2886(\mathrm{w}), 2852(\mathrm{w}), 1642$ (vs, C=O), 1589 (s, C=C), 1555 (w, C=C), 1489 (s), 1222 (m, C-F), $1156(m), 1022$ (w), 835 (m, sp² C-H), 752 (s, sp² C-H).

m.p. $=215-218^{\circ} \mathrm{C}$.

\subsubsection{3-((4-Chlorophenyl)thio)-2-quinolone (7d)}

Following GP1 the entitled sulfide 7d was obtained as an off-white solid (197 mg, $685 \mu \mathrm{mol}$,<smiles>Cc1ccc(Sc2cc3ccccc3[nH]c2=O)cc1</smiles>
$46 \%)$.

$\boldsymbol{R}_{\mathbf{f}}\left(30 \% \mathrm{EtOAC} / \mathrm{CH}_{2} \mathrm{Cl}_{2}\right): 0.69$.

${ }^{1} \mathrm{H}$ NMR $\left(500 \mathrm{MHz}, \mathrm{DMSO}-d_{6}\right) \delta[\mathrm{ppm}]=12.1$ (bs, $\left.1 \mathrm{H}, \mathrm{NH}\right), 7.58-7.51\left(\mathrm{~m}, 5 \mathrm{H}, \mathrm{H}-5, \mathrm{H}-2^{\prime}, \mathrm{H}-3^{\prime}\right)$, 7.45 (ddd, ${ }^{3} J=8.5,7.2 \mathrm{~Hz},{ }^{4} J=1.4 \mathrm{~Hz}, 1 \mathrm{H}, \mathrm{H}-7$ ), 7.40 (s, $\left.1 \mathrm{H}, \mathrm{H}-4\right), 7.32\left(\mathrm{dd},{ }^{3} \mathrm{~J}=8.2 \mathrm{~Hz},{ }^{4} \mathrm{~J}=1.0 \mathrm{~Hz}, 1 \mathrm{H}, \mathrm{H}-8\right), 7.13$ (ddd, ${ }^{3} \mathrm{~J}=8.2 \mathrm{~Hz}, 7.2 \mathrm{~Hz},{ }^{4} \mathrm{~J}=1.1 \mathrm{~Hz}, 1 \mathrm{H}, \mathrm{H}-6$ ).

${ }^{13} \mathrm{C}$ NMR $\left(126 \mathrm{MHz}\right.$, DMSO-d $\left.d_{6}\right) \delta[\mathrm{ppm}]=159.1$ (C-2), 137.1 (C-8a), 135.0 (C-2'), 134.7 (C-4), 133.6 (C-3), 131.1 (C1'), 130.2 (C-7), 130.0 (C-3'), 129.7 (C-4'), 127.1 (C-5), 122.2 (C-6), 119.3 (C-4a), 115.1 (C-8).

HRMS (+ESI): calc. for $\mathrm{C}_{15} \mathrm{H}_{11} \mathrm{OCINS}[\mathrm{M}+\mathrm{H}]^{+}:$288.0244; found: 288.0246 .

IR (ATR) $\tilde{v}\left[\mathrm{~cm}^{-1}\right]=3152(\mathrm{w}, \mathrm{N}-\mathrm{H}), 2927$ (w), $2886(\mathrm{w}), 2852(\mathrm{w}), 1647$ (vs, C=O), 1555 (w, C=C), 1475 (m), 1093 (m, C-Cl), $1012(\mathrm{~m}), 831\left(\mathrm{~m}, \mathrm{sp}^{2} \mathrm{C}-\mathrm{H}\right), 751\left(\mathrm{~m}, \mathrm{sp}^{2} \mathrm{C}-\mathrm{H}\right)$

m.p. $=211-214^{\circ} \mathrm{C}$. 
2.1.4. 3-((4-Bromophenyl)thio)-2-quinolone (7e)

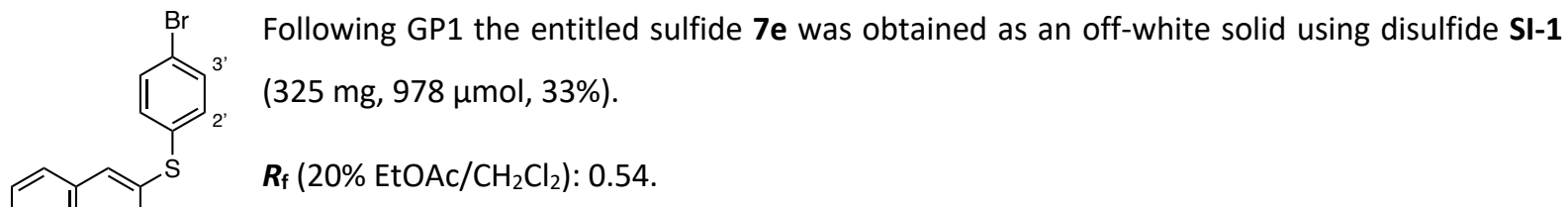

${ }^{1} \mathrm{H}$ NMR $\left(500 \mathrm{MHz}, \mathrm{DMSO}-\mathrm{d}_{6}\right) \delta[\mathrm{ppm}]=12.2$ (bs, 1H, NH), 7.70-7.64 (m, 2H, H-3'), 7.56 (dd, ${ }^{3} \mathrm{~J}$ $\left.=7.9,{ }^{4} \mathrm{~J}=1.4 \mathrm{~Hz}, 1 \mathrm{H}, \mathrm{H}-5\right), 7.49-7.43\left(\mathrm{~m}, 4 \mathrm{H}, \mathrm{H}-4, \mathrm{H}-7, \mathrm{H}-2^{\prime}\right), 7.32\left(\mathrm{~d},{ }^{3} \mathrm{~J}=8.2 \mathrm{~Hz}, 1 \mathrm{H}, \mathrm{H}-8\right), 7.17-7.11(\mathrm{~m}, 1 \mathrm{H}, \mathrm{H}-6)$.

${ }^{13} \mathrm{C}$ NMR (126 MHz, DMSO- $d_{6}$ ) $\delta$ [ppm] = 159.1 (C-2), 137.2 (C-8a), 135.1 (C-4), 135.0 (C-2'), 132.9 (C-3'), 130.9 $\left(C-3^{+}\right), 130.8\left(C^{-1}-^{\prime}\right), 129.8(C-7), 127.2(C-5), 122.2$ (2C, C-6 and C-4'), 119.3 (C-4a), 115.1 (C-8).

${ }^{\dagger}$ assignment is interconvertible

HRMS (+ESI): calc. for $\mathrm{C}_{15} \mathrm{H}_{11} \mathrm{OBrNS}[\mathrm{M}+\mathrm{H}]^{+}:$: 311.9739; found: 311.9754 .

IR (ATR) $\tilde{v}\left[\mathrm{~cm}^{-1}\right]=3136(\mathrm{w}, \mathrm{N}-\mathrm{H}), 2989$ (w), 2930 (w), 2843 (w), 1646 (vs, C=O), 1556 (w, C=C), 1472 (m), 1066 (m, C-Br), $1010(\mathrm{~m}), 831$ (w, sp $\left.{ }^{2} \mathrm{C}-\mathrm{H}\right), 750$ (s, sp $\left.\mathrm{sp}^{2} \mathrm{H}\right)$.

m.p. $=217-220^{\circ} \mathrm{C}$

\subsubsection{6-Methyl-3-phenylthio-2-quinolone (7g)}<smiles>Cc1ccc2[nH]c(=O)c(Sc3ccccc3)cc2c1</smiles>
Following GP1 the entitled sulfide $7 \mathrm{~g}$ was obtained as an off-white solid from 6-methyl quinolone $\mathrm{s}^{3}$ (186 mg, $\left.696 \mu \mathrm{mol}, 35 \%\right)$.

$\boldsymbol{R}_{\mathrm{f}}\left(20 \% \mathrm{EtOAc} / \mathrm{CH}_{2} \mathrm{Cl}_{2}\right): 0.47$.

${ }^{1} \mathrm{H}$ NMR $\left(400 \mathrm{MHz}, \mathrm{DMSO}-d_{6}\right) \delta[\mathrm{ppm}]=12.0$ (bs, $\left.1 \mathrm{H}, \mathrm{NH}\right), 7.55-7.46\left(\mathrm{~m}, 5 \mathrm{H}, \mathrm{H}-2^{\prime}, \mathrm{H}-3^{\prime}\right.$ and H-4') , 7.28-7.25 (m, 1H, H-7), 7.25-7.24 (m, 1H, H-5), 7.21 (d, $\left.{ }^{3} \mathrm{~J}=8.2 \mathrm{~Hz}, 1 \mathrm{H}, \mathrm{H}-8\right), 7.12$ (s, $\left.1 \mathrm{H}, \mathrm{H}-4\right), 2.27(\mathrm{~s}, 3 \mathrm{H}$, $\left.\mathrm{CH}_{3}\right)$.

${ }^{13} \mathrm{C}$ NMR $\left(126 \mathrm{MHz}\right.$, DMSO- $\left.d_{6}\right) \delta$ [ppm] = 159.0 (C-2), 134.8 (C-8a), 133.9 (C-2'), 133.0 (C-4), 132.3 (C-3), 131.2 (C6), 130.7 (2C, C-7 and C-1'), 130.1 (C-3'), 129.1 (C-4'), 126.3 (C-5), 119.2 (C-4a), 115.0 (C-8), $20.3\left(\mathrm{CH}_{3}\right)$.

HRMS (+ESI): calc. for $\mathrm{C}_{16} \mathrm{H}_{14} \mathrm{ONS}[\mathrm{M}+\mathrm{H}]^{+}:$268.0791; found: 268.0792 .

IR (ATR) $\tilde{v}\left[\mathrm{~cm}^{-1}\right]=3142(\mathrm{w}, \mathrm{N}-\mathrm{H}), 3018(\mathrm{w}), 2983(\mathrm{w}), 2916(\mathrm{w}), 2861(\mathrm{w}), 1641$ (vs, C=O), 1561 (w, C=C), 1472 (w), $1031(w), 896(m), 865\left(w, s^{2} C-H\right), 812\left(m, s p^{2} C-H\right), 754\left(m, s^{2} C-H\right)$.

m.p. $=229-232^{\circ} \mathrm{C}$. 
<smiles>Cc1ccc2cc(Sc3ccccc3)c(=O)[nH]c2c1</smiles>

Following GP1 the entitled sulfide $7 \mathrm{~h}$ was obtained as an off-white solid from 7-methyl quinolone ${ }^{3}$ (120 mg, $\left.449 \mu \mathrm{mol}, 22 \%\right)$.

$\boldsymbol{R}_{\mathbf{f}}\left(20 \% \mathrm{EtOAC} / \mathrm{CH}_{2} \mathrm{Cl}_{2}\right): 0.45$

${ }^{1} \mathrm{H}$ NMR $\left(400 \mathrm{MHz}, \mathrm{DMSO}-d_{6}\right) \delta[\mathrm{ppm}]=12.0$ (bs, $\left.1 \mathrm{H}, \mathrm{NH}\right), 7.53-7.44\left(\mathrm{~m}, 5 \mathrm{H}, \mathrm{H}-2^{\prime}, \mathrm{H}-3^{\prime}\right.$ and H-4'), $7.36\left(d,{ }^{3} J=8.1 \mathrm{~Hz}, 1 \mathrm{H}, \mathrm{H}-5\right), 7.25(\mathrm{~s}, 1 \mathrm{H}, \mathrm{H}-4), 7.11-7.09(\mathrm{~m}, 1 \mathrm{H}, \mathrm{H}-8), 6.96\left(\mathrm{dd},{ }^{3} \mathrm{~J}=8.2 \mathrm{~Hz},{ }^{3} \mathrm{~J}=1.6 \mathrm{~Hz}, 1 \mathrm{H}\right.$, $\mathrm{H}-6), 2.35\left(\mathrm{~s}, 3 \mathrm{H}, \mathrm{CH}_{3}\right)$.

${ }^{13} \mathrm{C}$ NMR $\left(126 \mathrm{MHz}, \mathrm{DMSO}-d_{6}\right) \delta[\mathrm{ppm}]=159.3$ (C-2), 139.7 (C-7), 137.2 (C-8a), 134.1 (C-4), 133.4 (C-2'), 131.2 (C1'), 130.5 (C-3), 130.0 (C-3'), 128.8 (C-4'), 126.8 (C-5), 123.6 (C-6), 117.2 (C-4a), 114.8 (C-8), $21.4\left(\mathrm{CH}_{3}\right)$.

HRMS (+ESI): calc. for $\mathrm{C}_{16} \mathrm{H}_{14} \mathrm{ONS}[\mathrm{M}+\mathrm{H}]^{+}:$: 268.0791; found: 268.0791.

IR (ATR) $\tilde{v}\left[\mathrm{~cm}^{-1}\right]=2957(\mathrm{~m}), 2924(\mathrm{~m}), 2856(\mathrm{~m}), 1640(\mathrm{~s}, \mathrm{C}=0), 1553(\mathrm{~m}, \mathrm{C}=\mathrm{C}), 1374(\mathrm{~m}), 1220(\mathrm{~s}), 1109(\mathrm{w})$, $1036(m), 1023(w), 895(m), 869\left(w, s^{2} C-H\right), 832\left(m, s p^{2} C-H\right), 801\left(m, s p^{2} C-H\right), 756\left(s, s p^{2} C-H\right)$.

m.p. $=250-253^{\circ} \mathrm{C}$.

\subsubsection{3-((3-Fluorophenyl)thio)-2-quinolone (7k)}<smiles>O=c1[nH]c2ccccc2cc1Sc1cccc(F)c1</smiles>

Following GP1 the entitled sulfide 7k was obtained as an off-white solid ( $282 \mathrm{mg}, 1.04 \mu \mathrm{mol}$, $52 \%)$.

$\boldsymbol{R}_{\mathrm{f}}\left(20 \% \mathrm{EtOAC} / \mathrm{CH}_{2} \mathrm{Cl}_{2}\right): 0.48$.

${ }^{1}$ H NMR $\left(400 \mathrm{MHz}, \mathrm{DMSO}-d_{6}\right) \delta[\mathrm{ppm}]=12.2(\mathrm{~s}, 1 \mathrm{H}, \mathrm{NH}), 7.60-7.43(\mathrm{~m}, 4 \mathrm{H}, \mathrm{H}-4, \mathrm{H}-5, \mathrm{H}-7, \mathrm{H}-$ $\left.5^{\prime}\right)$, 7.38-7.31 (m, 3H, H-8, H-4', H-6'), $7.28\left(\mathrm{td},{ }^{3} \mathrm{~J}=8.7 \mathrm{~Hz},{ }^{4} \mathrm{~J}=2.6 \mathrm{~Hz}, 1 \mathrm{H}, \mathrm{H}-2^{\prime}\right), 7.18-7.12(\mathrm{~m}, 1 \mathrm{H}, \mathrm{H}-6)$.

${ }^{13} \mathrm{C}$ NMR $\left(126 \mathrm{MHz}, \mathrm{DMSO}-d_{6}\right) \delta[\mathrm{ppm}]=162.5\left(\mathrm{~d},{ }^{1} \mathrm{~J}_{\mathrm{CF}}=246.8 \mathrm{~Hz}, \mathrm{C}-3^{\prime}\right), 159.1$ (C-2), 137.4 (C-8a), 136.2 (C-4), $134.1\left(\mathrm{~d},{ }^{3} \mathrm{~J}_{\mathrm{CF}}=7.9 \mathrm{~Hz}, \mathrm{C}-\mathrm{1}^{\prime}\right), 131.6\left(\mathrm{~d},{ }^{3} \mathrm{~J}_{\mathrm{CF}}=8.5 \mathrm{~Hz}, \mathrm{C}-5^{\prime}\right), 130.1(\mathrm{C}-3), 130.0(\mathrm{C}-7), 128.6\left(\mathrm{~d},{ }^{4} \mathrm{~J}_{\mathrm{CF}}=3.0 \mathrm{~Hz}, \mathrm{C}-6^{\prime}\right)$, 127.2 (C-5), 122.2 (C-6), 119.3 (C-4a), 119.1 (d, ${ }^{2} J_{\mathrm{CF}}=22.4 \mathrm{~Hz}, \mathrm{C}-4^{\prime}$ ), 115.5 (d, $\left.{ }^{2} J_{\mathrm{CF}}=21.0 \mathrm{~Hz}, \mathrm{C}-2^{\prime}\right), 115.1$ (C-8).

${ }^{19} \mathrm{~F}$ NMR $\left(376 \mathrm{MHz}, \mathrm{DMSO}-d_{6}\right) \delta[\mathrm{ppm}]=-111.4\left(\mathrm{td},{ }^{3} \mathrm{~J}=9.1 \mathrm{~Hz},{ }^{4} J=6.1 \mathrm{~Hz}, 1 \mathrm{~F}\right)$.

HRMS (+ESI): calc. for $\mathrm{C}_{15} \mathrm{H}_{11} \mathrm{OFNS}[\mathrm{M}+\mathrm{H}]^{+}$: 272.0540; found: 272. 0540.

IR (ATR) $\tilde{v}\left[\mathrm{~cm}^{-1}\right]=2994(w), 2932(\mathrm{w}), 2887$ (w), 1643 (vs, C=O), $1581(\mathrm{~m}), 1555$ (m, C=C), $1472(\mathrm{w}), 1429(\mathrm{w})$, 1262 (w), 1217 (s, C-F), 1022 (w), 882 (w), 869 (m, sp² C-H), 791 (w, sp² C-H), 746 (s, sp² C-H).

m.p. $=204-207^{\circ} \mathrm{C}$ 


\subsection{General procedure 2 (GP2): synthesis of sulfides 7 from 2-bromoquinolone $\mathbf{S I - 2}$}
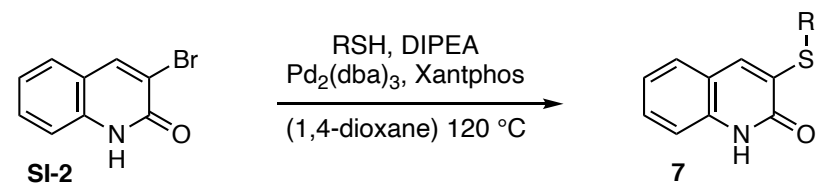

Following a procedure by Itoh et al., ${ }^{4}$ a suspension of 3-bromo-2-quinolone (SI-2) (1.0 equiv), DIPEA (2.0 equiv) in 1,4-dioxane $(0.3 \mathrm{M})$ was degassed by consecutive evacuation to vacuum and argon $(3 \mathrm{cycles}) . \mathrm{Pd}_{2}\left(\mathrm{dba}_{3}\right.$ (2.5 mol\%), Xantphos (5 mol\%) and the corresponding thiol (2.1 equiv) were added whereupon the mixture was repeatedly degassed ( 2 cycles). The reaction mixture was heated to $120^{\circ} \mathrm{C}$ for $16 \mathrm{~h}$ before it was cooled to ambient temperature. The suspension was filtered over a sintered glass funnel and the residual solids were washed with acetone and $\mathrm{MeOH}$. The filtrated was concentrated under reduced pressure and the crude material was purified by FCC $\left(10 \% \rightarrow 25 \% \mathrm{EtOAc} / \mathrm{CH}_{2} \mathrm{Cl}_{2}\right)$ to yield the entitled sulfide 7 .

\subsubsection{3-Phenylthio-2-quinolone (7a)}<smiles>O=c1[nH]c2ccccc2cc1Sc1ccccc1</smiles>

Following GP2 the entitled sulfide 7a was obtained as a white solid (972 mg, $3.84 \mathrm{mmol}, 96 \%$ ).

$\boldsymbol{R}_{\mathbf{f}}\left(20 \% \mathrm{EtOAc} / \mathrm{CH}_{2} \mathrm{Cl}_{2}\right): 0.70$.

${ }^{1} \mathrm{H}$ NMR $\left(500 \mathrm{MHz}, \mathrm{DMSO}-d_{6}\right) \delta[\mathrm{ppm}]=12.1(\mathrm{~s}, 1 \mathrm{H}), 7.57-7.41\left(\mathrm{~m}, 7 \mathrm{H}, \mathrm{H}-5, \mathrm{H}-7, \mathrm{H}-2^{\prime}, \mathrm{H}-3\right.$ ', H$\left.4^{\prime}\right), 7.31\left(\mathrm{dd},{ }^{3} \mathrm{~J}=8.3 \mathrm{~Hz},{ }^{4} \mathrm{~J}=1.0 \mathrm{~Hz}, 1 \mathrm{H}, \mathrm{H}-8\right), 7.22(\mathrm{~s}, 1 \mathrm{H}, \mathrm{H}-4), 7.12$ (virt td, ${ }^{3} \mathrm{~J}=7.5 \mathrm{~Hz},{ }^{4} \mathrm{~J}=$ $1.2 \mathrm{~Hz}, 1 \mathrm{H}, \mathrm{H}-6)$.

${ }^{13} \mathrm{C}$ NMR (126 MHz, DMSO-d $)_{6} \delta$ [ppm] = 159.1 (C-2), 136.9 (C-8a), $133.8\left(\mathrm{C}-2^{\prime \dagger}\right), 133.3$ (C-4), 132.3 (C-3), 130.7 $\left(C-1^{\prime}\right), 130.1\left(C^{\prime \prime} 3^{\prime}\right), 129.5$ (C-7), 129.1 (C-4'), 126.8 (C-5), 122.2 (C-6), 119.3 (C-4a), 115.0 (C-8).

${ }^{\dagger}$ assignment is interconvertible

HRMS (+ESI): calc. for $\mathrm{C}_{15} \mathrm{H}_{12} \mathrm{ONS}[\mathrm{M}+\mathrm{H}]^{+}:$254.0634; found: 254.0631.

IR (ATR) $\tilde{v}\left[\mathrm{~cm}^{-1}\right]=2843(\mathrm{w}), 1640(\mathrm{~s}), 1553(\mathrm{~m}), 1218(\mathrm{~m}), 1020(\mathrm{~m}), 891(\mathrm{~s}), 746$ (vs).

m.p. $=207-210^{\circ} \mathrm{C}$.

\subsubsection{3-((4-(Trifluoromethyl)phenyl)thio)-2-quinolone (7f)}

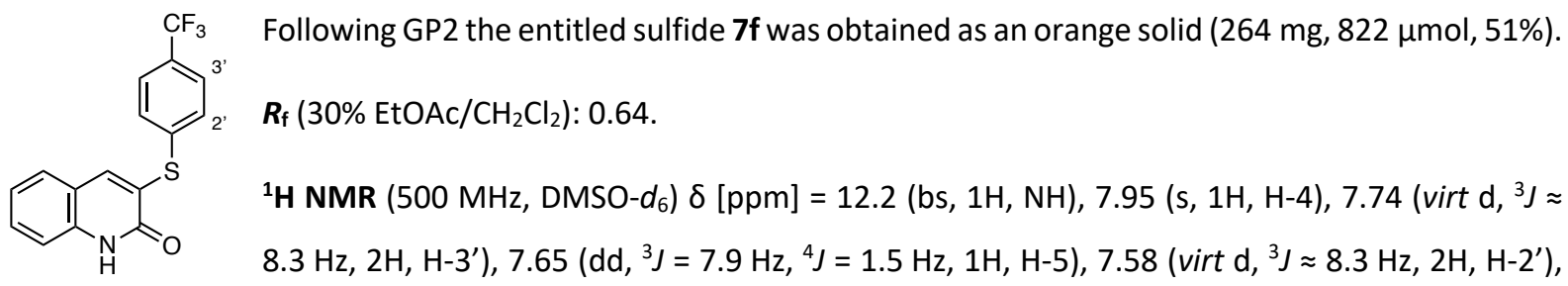


$7.52\left(\mathrm{ddd},{ }^{3} \mathrm{~J}=8.4,7.2 \mathrm{~Hz},{ }^{4} \mathrm{~J}=1.4 \mathrm{~Hz}, 1 \mathrm{H}, \mathrm{H}-7\right), 7.35$ (dd, $\left.{ }^{3} \mathrm{~J}=8.3 \mathrm{~Hz},{ }^{4} J=1.0 \mathrm{~Hz}, 1 \mathrm{H}, \mathrm{H}-8\right), 7.19$ (ddd, ${ }^{3} \mathrm{~J}=8.1$, $\left.7.2 \mathrm{~Hz},{ }^{4} J=1.1 \mathrm{~Hz}, 1 \mathrm{H}, \mathrm{H}-6\right)$.

${ }^{13} \mathrm{C}$ NMR $(126 \mathrm{MHz}$, DMSO-d 6 ) $\delta$ [ppm] = 159.2 (C-2), 140.5 (C-4), 139.2 (C-1'), 138.3 (C-8a), 130.7 (C-7), 130.6 (C$\left.2^{\prime}\right), 127.7(C-5), 127.5\left(q,{ }^{2} J_{C F}=32.1 \mathrm{~Hz}, C-4^{\prime}\right), 127.2(C-3), 126.2\left(q,{ }^{3} J_{C F}=4.2 \mathrm{~Hz}, C-3^{\prime}\right), 124.2\left(q,{ }^{1} J_{C F}=271.9 \mathrm{~Hz}\right.$, $\left.\mathrm{CF}_{3}\right), 122.2(\mathrm{C}-6), 119.2$ (C-4a), $115.2(\mathrm{C}-8)$.

${ }^{19}$ F NMR $\left(376 \mathrm{MHz}, \mathrm{DMSO}-d_{6}\right) \delta[\mathrm{ppm}]=-61.0(\mathrm{~s}, 3 \mathrm{~F})$.

HRMS (+ESI): calc. for $\mathrm{C}_{16} \mathrm{H}_{11} \mathrm{OF}_{3} \mathrm{NS}[\mathrm{M}+\mathrm{H}]^{+}:$322.0508; found: 322.0519 .

IR (ATR) $\tilde{v}\left[\mathrm{~cm}^{-1}\right]=2924(\mathrm{w}), 2853(\mathrm{w}), 1655$ (s, C=O), 1603 (m, C=C), 1402 (w), 1325 (vs, C-F), 1107 (s), 1093 (s), $1063(\mathrm{~s}), 830\left(\mathrm{~m}, \mathrm{sp}^{2} \mathrm{C}-\mathrm{H}\right), 753\left(\mathrm{~s}, \mathrm{sp}^{2} \mathrm{C}-\mathrm{H}\right)$.

m.p. $=237-240^{\circ} \mathrm{C}$.

\subsubsection{3-(Naphthalen-2-ylthio)-2-quinolone (7i)}<smiles>O=c1[nH]c2ccccc2cc1Sc1ccc2ccccc2c1</smiles>
Following GP2 the entitled sulfide $7 \mathbf{i}$ was obtained as a white solid (190 mg, $626 \mu \mathrm{mol}, 31 \%$ ). $\boldsymbol{R}_{\mathrm{f}}\left(30 \% \mathrm{EtOAC} / \mathrm{CH}_{2} \mathrm{Cl}_{2}\right): 0.68$ ${ }^{1} \mathrm{H}$ NMR $\left(500 \mathrm{MHz}, \mathrm{DMSO}-\mathrm{d}_{6}\right) \delta[\mathrm{ppm}]=12.2(\mathrm{bs}, 1 \mathrm{H}, \mathrm{NH}), 8.18\left(\mathrm{~d},{ }^{4} \mathrm{~J}=1.8 \mathrm{~Hz}, 1 \mathrm{H}, \mathrm{H}-1^{\prime}\right), 8.03$ $\left(\mathrm{d},{ }^{3} \mathrm{~J}=8.5 \mathrm{~Hz}, 1 \mathrm{H}, \mathrm{H}-4^{\prime}\right), 7.99\left(\mathrm{~m}, 2 \mathrm{H}, \mathrm{H}-6^{\prime}, \mathrm{H}-7^{\prime}\right), 7.64-7.55\left(\mathrm{~m}, 3 \mathrm{H}, \mathrm{H}-3^{\prime}, \mathrm{H}-5^{\prime}, \mathrm{H}-7^{\prime}\right), 7.47-7.40$ (m, 2H, H-5, H-7), 7.34-7.30 (m, 2H, H-4, H-8), 7.09 (ddd, $\left.{ }^{3} J=7.5,7.1 \mathrm{~Hz},{ }^{4} J=1.1 \mathrm{~Hz}, 1 \mathrm{H}, \mathrm{H}-6\right)$.

${ }^{13} \mathrm{C}$ NMR (126 MHz, DMSO-d $d_{6}$ ) [ppm] = 159.1 (C-2), 136.9 (C-8a), 133.7 (C-8a'), 133.6 (C-4), 133.1 (C-1'), 132.7 (C-4a'), 132.2 (C-3), 130.3 (C-3'), 129.6 (C-4'), 129.5 (C-7), 128.2 (C-2'), $127.8\left(\right.$ C-6 $\left.^{\prime \dagger}\right), 127.7\left(C-7^{\prime \dagger}\right), 127.1\left(C-8^{\prime}\right)$, 126.9 (2C, C-5, C-5'), 122.1 (C-6), 119.4 (C-4a), 115.0 (C-8).

${ }^{\dagger}$ assignment is interconvertible

HRMS (+ESI): calc. for $\mathrm{C}_{19} \mathrm{H}_{14} \mathrm{ONS}[\mathrm{M}+\mathrm{H}]^{+}$: 304.0791; found: 304.0791.

IR (ATR) $\tilde{v}\left[\mathrm{~cm}^{-1}\right]=2924(\mathrm{~m}), 2853(\mathrm{~m}), 1644$ (vs, C=O), 1602 (m, C=C), $1552(\mathrm{~m}, \mathrm{C}=\mathrm{C}), 1430(\mathrm{w}), 1261$ (w), 811 (w), $750\left(\mathrm{~m}, \mathrm{sp}^{2} \mathrm{C}-\mathrm{H}\right), 730\left(\mathrm{~m}, \mathrm{sp}^{2} \mathrm{C}-\mathrm{H}\right)$.

m.p. $=220-223^{\circ} \mathrm{C}$.

\subsubsection{3-(m-Tolylthio)-2-quinolone (7j)}<smiles>Cc1cccc(Sc2cc3ccccc3[nH]c2=O)c1</smiles>
Following GP2 the entitled sulfide $7 \mathbf{j}$ was obtained as a white solid (520 mg, $1.95 \mathrm{mmol}, 97 \%$ ). $\boldsymbol{R}_{\mathbf{f}}\left(30 \% \mathrm{EtOAc} / \mathrm{CH}_{2} \mathrm{Cl}_{2}\right): 0.68$.

${ }^{1} \mathrm{H}$ NMR $\left(500 \mathrm{MHz}\right.$, DMSO- $\left.d_{6}\right) \delta[\mathrm{ppm}]=12.1$ (bs, 1H, NH), 7.48-7.35 (m, 4H, H-5, H-7, H-2', H$\left.5^{\prime}\right)$, 7.35-7.27 (m, 3H, H-8, H-4', H-6'), $7.21(\mathrm{~s}, 1 \mathrm{H}, \mathrm{H}-4), 7.11$ (ddd, ${ }^{3} \mathrm{~J}=8.0,7.3 \mathrm{~Hz},{ }^{4} \mathrm{~J}=1.2 \mathrm{~Hz}$, $1 \mathrm{H}, \mathrm{H}-6), 2.35\left(\mathrm{~s}, 3 \mathrm{H}, \mathrm{CH}_{3}\right)$. 
${ }^{13} \mathrm{C}$ NMR (126 MHz, DMSO-d $) \delta$ [ppm] = 159.1 (C-2), 139.6 (C-3'), 136.8 (C-8a), 134.3 (C-2'), 133.0 (C-4), 132.5 (C-3), $131.0\left({\mathrm{C}-5^{\prime}}^{\dagger}\right), 130.3\left(\mathrm{C}-1^{\prime}\right), 129.9\left(\mathrm{C}-6^{\prime \dagger}\right), 129.8$ (C-4'), 129.4 (C-7), 126.8 (C-5), 122.2 (C-6), 119.3 (C-4a), 115.0 (C-8), $20.9\left(\mathrm{CH}_{3}\right)$.

${ }^{\dagger}$ assignment is interconvertible

HRMS (+ESI): calc. for $\mathrm{C}_{16} \mathrm{H}_{14} \mathrm{ONS}[\mathrm{M}+\mathrm{H}]^{+}:$268.0791; found: 268.0791.

IR (ATR) $\tilde{v}\left[\mathrm{~cm}^{-1}\right]=2937\left(\mathrm{~m}, \mathrm{sp}^{3} \mathrm{C}-\mathrm{H}\right), 2872\left(\mathrm{~m}, \mathrm{sp}^{3} \mathrm{C}-\mathrm{H}\right), 1644$ (vs, C=O), 1603 (m, C=C), 1555 (s, C=C), 1435 (m), $1212(\mathrm{~m}), 1031(\mathrm{~m}), 884(\mathrm{~m}), 742\left(\mathrm{~s}, \mathrm{sp}^{2} \mathrm{C}-\mathrm{H}\right)$.

m.p. $=189-192^{\circ} \mathrm{C}$.

2.2.5. 3-(o-Tolylthio)-2-quinolone (기)<smiles>Cc1ccccc1Sc1cc2ccccc2[nH]c1=O</smiles>

Following GP2 the entitled sulfide 7 I was obtained as a white solid ( $246 \mathrm{mg}, 920 \mu \mathrm{mol}, 46 \%$ ). $\boldsymbol{R}_{\mathrm{f}}\left(30 \% \mathrm{EtOAc} / \mathrm{CH}_{2} \mathrm{Cl}_{2}\right): 0.62$.

${ }^{1} \mathrm{H}$ NMR $\left(500 \mathrm{MHz}, \mathrm{DMSO}-\mathrm{d}_{6}\right) \delta[\mathrm{ppm}]=12.1$ (bs, $\left.1 \mathrm{H}, \mathrm{NH}\right), 7.52\left(\mathrm{dd},{ }^{3} \mathrm{~J}=7.7 \mathrm{~Hz},{ }^{4} \mathrm{~J}=1.3 \mathrm{~Hz}, 1 \mathrm{H}\right.$, H-6'), 7.49-7.38 (m, 4H, H-5, H-7, H-3', H-4'), 7.09 (ddd, $\left.{ }^{3} J=8.0,7.3 \mathrm{~Hz},{ }^{4} J=1.0 \mathrm{~Hz}, 1 \mathrm{H}, \mathrm{H}-6\right), 6.87(\mathrm{~s}, 1 \mathrm{H}, \mathrm{H}-4)$, $2.35\left(\mathrm{~s}, 3 \mathrm{H}, \mathrm{CH}_{3}\right)$.

${ }^{13} \mathrm{C}$ NMR (126 MHz, DMSO-d $)_{6} \delta$ [ppm] = 159.1 (C-2), 141.7 (C-2'), 136.6 (C-8a), 135.6 (C-6'), 131.9 (C-3), 131.3 (C-4), 131.3 (C-2'), 130.0 (C-4'), 129.2 (C-1'), 129.1 (C-7), 127.6 (C-5'), 126.6 (C-5), 122.2 (C-6), 119.4 (C-4a), 115.1 (C-8), $20.0\left(\mathrm{CH}_{3}\right)$.

HRMS (+ESI): calc. for $\mathrm{C}_{16} \mathrm{H}_{14} \mathrm{ONS}[\mathrm{M}+\mathrm{H}]^{+}:$: 268.0791; found: 268.0791.

IR (ATR) $\tilde{v}\left[\mathrm{~cm}^{-1}\right]=2926\left(\mathrm{~m}, \mathrm{sp}^{3} \mathrm{C}-\mathrm{H}\right), 2852\left(\mathrm{~m}, \mathrm{sp}^{3} \mathrm{C}-\mathrm{H}\right), 1651$ (vs, C=O), $1603(\mathrm{~m}, \mathrm{C}=\mathrm{C}), 1552(\mathrm{~m}, \mathrm{C}=\mathrm{C}), 1429(\mathrm{~m})$, $1211(w), 900(w), 827(w), 751\left(m, s p^{2} C-H\right), 732\left(m, s p^{2} C-H\right)$

m.p. $=232-235^{\circ} \mathrm{C}$.

\subsubsection{3-((2-Ethylphenyl)thio)-2-quinolone (7m)}

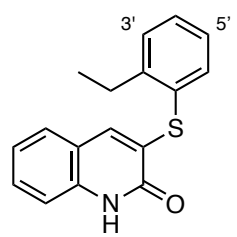

Following GP2 the entitled sulfide $7 \mathrm{~m}$ was obtained as a white solid (550 mg, $1.95 \mathrm{mmol}, 98 \%$ ). $\boldsymbol{R}_{\mathbf{f}}\left(20 \% \mathrm{EtOAc} / \mathrm{CH}_{2} \mathrm{Cl}_{2}\right): 0.56$.

${ }^{1} \mathbf{H}$ NMR $\left(500 \mathrm{MHz}, \mathrm{DMSO}-d_{6}\right) \delta[\mathrm{ppm}]=12.1$ (bs, 1H, NH), 7.55-7.46 (m, 3H, H-3', H-4', H-6'), 7.43-7.32 (m, 3H, H-5, H-7, H-5'), 7.31 (dd, $\left.{ }^{3} J=8.2 \mathrm{~Hz},{ }^{4} J=1.1 \mathrm{~Hz}, 1 \mathrm{H}, \mathrm{H}-8\right), 7.09$ (ddd, ${ }^{3} J=8.2,7.2 \mathrm{~Hz},{ }^{4} \mathrm{~J}=1.2 \mathrm{~Hz}$, $1 \mathrm{H}, \mathrm{H}-6), 6.86(\mathrm{~s}, 1 \mathrm{H}, \mathrm{H}-4), 2.73\left(\mathrm{q},{ }^{3} \mathrm{~J}=7.5 \mathrm{~Hz}, 2 \mathrm{H}, \mathrm{CH}_{2}\right), 1.14\left(\mathrm{t}, 3 \mathrm{~J}=7.5 \mathrm{~Hz}, 3 \mathrm{H}, \mathrm{CH}_{3}\right)$.

${ }^{13} \mathrm{C}$ NMR (126 MHz, DMSO-d (1) $\delta$ [ppm] = 159.1 (C-2), 147.6 (C-2'), 136.5 (C-8a), 136.0 (C-6'), 133.0 (C-3), 131.3, (C-4), $130.2\left({\mathrm{C}-3^{\prime+}}^{+}\right), 129.9\left(\mathrm{C}-4^{\prime \dagger}\right), 129.2(\mathrm{C}-7), 128.4\left(\mathrm{C}-1^{\prime}\right), 127.7$ (C-5'), 126.6 (C-5), 122.2 (C-6), 119.3 (C-4a), $115.1(\mathrm{C}-8), 26.7\left(\mathrm{CH}_{2}\right), 15.5\left(\mathrm{CH}_{2}\right)$. 
${ }^{\dagger}$ assignment is interconvertible

HRMS (+ESI): calc. for $\mathrm{C}_{17} \mathrm{H}_{16} \mathrm{ONS}[\mathrm{M}+\mathrm{H}]^{+}:$282.0947; found: 282.0947.

IR (ATR) $\tilde{v}\left[\mathrm{~cm}^{-1}\right]=2964\left(\mathrm{~m}, \mathrm{sp}^{3} \mathrm{C}-\mathrm{H}\right), 2929\left(\mathrm{~m}, \mathrm{sp}^{3} \mathrm{C}-\mathrm{H}\right), 2871\left(\mathrm{~m}, \mathrm{sp}^{3} \mathrm{C}-\mathrm{H}\right), 1638$ (vs, C=O), $1602(\mathrm{~m}, \mathrm{C}=\mathrm{C}), 1553$ $(\mathrm{m}, \mathrm{C}=\mathrm{C}), 1428(\mathrm{~m}), 1261(\mathrm{~m}), 1213(\mathrm{~m}), 1030(\mathrm{~m}), 827(\mathrm{w}), 751\left(\mathrm{~m}, \mathrm{sp}^{2} \mathrm{C}-\mathrm{H}\right), 733\left(\mathrm{~m}, \mathrm{sp}^{2} \mathrm{C}-\mathrm{H}\right)$

m.p. $=184-187^{\circ} \mathrm{C}$.

\subsubsection{3-((2-Methoxyphenyl)thio)-2-quinolone (7n)}

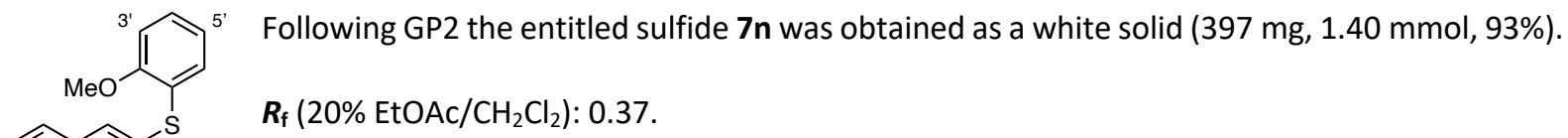

${ }^{1} \mathrm{H}$ NMR $\left(500 \mathrm{MHz}, \mathrm{DMSO}-d_{6}\right) \delta[\mathrm{ppm}]=12.1$ (bs, $\left.1 \mathrm{H}, \mathrm{NH}\right), 7.51\left(\mathrm{ddd},{ }^{3} \mathrm{~J}=8.2,7.4 \mathrm{~Hz},{ }^{4} \mathrm{~J}=1.7 \mathrm{~Hz}\right.$, $\left.1 \mathrm{H}, \mathrm{H}-4^{\prime}\right), 7.46-7.42\left(\mathrm{~m}, 2 \mathrm{H}, \mathrm{H}-5, \mathrm{H}-6^{\prime}\right), 7.42-7.39(\mathrm{~m}, 1 \mathrm{H}, \mathrm{H}-7), 7.31$ (dd, $\left.{ }^{3} \mathrm{~J}=8.2 \mathrm{~Hz},{ }^{4} \mathrm{~J}=1.1 \mathrm{~Hz}, 1 \mathrm{H}, \mathrm{H}-8\right), 7.21$ (dd, $\left.{ }^{3} J=8.4 \mathrm{~Hz},{ }^{4} \mathrm{~J}=1.2 \mathrm{~Hz}, 1 \mathrm{H}, \mathrm{H}-3^{\prime}\right), 7.11\left(\mathrm{ddd},{ }^{3} \mathrm{~J}=8.1,7.2 \mathrm{~Hz},{ }^{4} \mathrm{~J}=1.2 \mathrm{~Hz}, 1 \mathrm{H}, \mathrm{H}-6\right), 7.06\left(\mathrm{td},{ }^{3} \mathrm{~J}=7.5 \mathrm{~Hz},{ }^{4} \mathrm{~J}=1.2 \mathrm{~Hz}\right.$, $\left.1 \mathrm{H}, \mathrm{H}-5^{\prime}\right), 7.01(\mathrm{~s}, 1 \mathrm{H}, \mathrm{H}-4), 3.80\left(\mathrm{~s}, 3 \mathrm{H}, \mathrm{OCH}_{3}\right)$.

${ }^{13} \mathrm{C}$ NMR (126 MHz, DMSO- $\left.d_{6}\right) \delta[\mathrm{ppm}]=159.3$ (C-2), 159.2 (C-2'), 136.6 (C-8a), 135.5 (C-6'), 132.0 (C-4), 131.4 (C-4'), 131.0 (C-3), 129.1 (C-7), 126.6 (C-5), 122.1 (C-6), 121.6 (C-5'), 119.4 (C-4a), 117.5 (C-1'), 115.0 (C-8), 112.3 $\left(\mathrm{C}-3^{\prime}\right), 55.9\left(\mathrm{OCH}_{3}\right)$.

HRMS (+ESI): calc. for $\mathrm{C}_{16} \mathrm{H}_{14} \mathrm{O}_{2} \mathrm{NS}[\mathrm{M}+\mathrm{H}]^{+}:$: 284.0740; found: 284.0740 .

IR (ATR) $\tilde{v}\left[\mathrm{~cm}^{-1}\right]=2997\left(\mathrm{~m}, \mathrm{sp}^{3} \mathrm{C}-\mathrm{H}\right), 2875\left(\mathrm{~m}, \mathrm{sp}^{3} \mathrm{C}-\mathrm{H}\right), 2839\left(\mathrm{O}-\mathrm{CH}_{3}\right), 1636(\mathrm{vs}, \mathrm{C}=\mathrm{O}), 1603(\mathrm{~m}, \mathrm{C}=\mathrm{C}), 1552(\mathrm{~m}$, $C=C), 1429(m), 1248(w), 1022(m), 823(w), 751\left(s, s^{2} C-H\right), 733\left(m, s p^{2} C-H\right)$

m.p. $=215-218^{\circ} \mathrm{C}$.

\subsubsection{3-((2,6-Dimethylphenyl)thio)-2-quinolone (7o)}

Following GP2 the entitled sulfide 70 was obtained as a white solid ( $282 \mathrm{mg}, 1.00 \mathrm{mmol}, 67 \%$ ).<smiles>Cc1ccccc1Sc1cc2ccccc2[nH]c1=O</smiles>

$\boldsymbol{R}_{\mathbf{f}}\left(20 \%\right.$ EtOAc/ $\left.\mathrm{CH}_{2} \mathrm{Cl}_{2}\right): 0.45$.

${ }^{1} \mathrm{H}$ NMR $\left(500 \mathrm{MHz}, \mathrm{DMSO}-d_{6}\right) \delta[\mathrm{ppm}]=12.1$ (bs, $\left.1 \mathrm{H}, \mathrm{NH}\right), 7.42-7.36$ (m, 2H, H-4', H-7), 7.35$7.28\left(\mathrm{~m}, 4 \mathrm{H}, \mathrm{H}-5, \mathrm{H}-8, \mathrm{H}-3^{\prime}\right), 7.07$ (ddd, $\left.{ }^{3} \mathrm{~J}=8.1,7.1 \mathrm{~Hz},{ }^{4} \mathrm{~J}=1.2 \mathrm{~Hz}, 1 \mathrm{H}, \mathrm{H}-6\right), 6.52(\mathrm{~s}, 1 \mathrm{H}, \mathrm{H}-4)$, $2.37\left(\mathrm{~s}, 6 \mathrm{H}, \mathrm{CH}_{3}\right)$.

${ }^{13} \mathrm{C}$ NMR (126 MHz, DMSO-d $\left.d_{6}\right) \delta$ [ppm] = 159.3 (C-2), 143.4 (C-2'), 136.2 (C-8a), 131.8 (C-3), 130.1 (C-4'), 128.9 (C-7), $128.8\left(\mathrm{C}-3^{\prime}\right), 128.1$ (C-4), 127.7 (C-1'), 126.3 (C-5), 122.2 (C-6), 119.4 (C-4a), 115.0 (C-8), $21.0\left(\mathrm{CH}_{3}\right)$.

HRMS (+ESI): calc. for $\mathrm{C}_{17} \mathrm{H}_{16} \mathrm{ONS}[\mathrm{M}+\mathrm{H}]^{+}:$: 282.0947; found: 282.0947.

IR (ATR) $\tilde{v}\left[\mathrm{~cm}^{-1}\right]=2925\left(\mathrm{~m}, \mathrm{sp}^{3} \mathrm{C}-\mathrm{H}\right), 2848\left(\mathrm{~m}, \mathrm{sp}^{3} \mathrm{C}-\mathrm{H}\right), 1650$ (vs, C=O), $1602(\mathrm{~m}, \mathrm{C}=\mathrm{C}), 1552$ (m, C=C), 1430 (m), $1212(w), 944(w), 827(w), 752\left(s, s p^{2} C-H\right), 734\left(w, s p^{2} C-H\right)$ 
m.p. $=309-312^{\circ} \mathrm{C}$

2.2.9. 3-((2,3,5,6-Tetrafluorophenyl)thio)-2-quinolone (7p)<smiles>O=c1[nH]c2ccccc2cc1Sc1c(F)c(F)cc(F)c1F</smiles>

Following GP2 the entitled sulfide 7p was obtained as a white solid (63 mg, $194 \mu \mathrm{mol}, 13 \%$ ). $\boldsymbol{R}_{\mathbf{f}}\left(30 \% \mathrm{EtOAC} / \mathrm{CH}_{2} \mathrm{Cl}_{2}\right): 0.59$.

${ }^{1} \mathbf{H}$ NMR $\left(500 \mathrm{MHz}^{\mathrm{CDCl}}{ }_{3}\right) \delta[\mathrm{ppm}]=12.2(\mathrm{bs}, 1 \mathrm{H}, \mathrm{NH}), 7.54(\mathrm{~s}, 1 \mathrm{H}, \mathrm{H}-4), 7.52\left(\mathrm{ddd},{ }^{3} \mathrm{~J}=8.4\right.$, $\left.7.2 \mathrm{~Hz},{ }^{4} J=1.4 \mathrm{~Hz}, 1 \mathrm{H}, \mathrm{H}-7\right), 7.46\left(\mathrm{dd},{ }^{3} \mathrm{~J}=8.0 \mathrm{~Hz},{ }^{4} \mathrm{~J}=1.3 \mathrm{~Hz}, 1 \mathrm{H}, \mathrm{H}-5\right), 7.36\left(\mathrm{dd},{ }^{3} \mathrm{~J}=8.1 \mathrm{~Hz},{ }^{4} \mathrm{~J}\right.$ $=0.9 \mathrm{~Hz}, 1 \mathrm{H}, \mathrm{H}-8), 7.23\left(\mathrm{ddd},{ }^{3} \mathrm{~J}=8.1,7.2 \mathrm{~Hz},{ }^{4} \mathrm{~J}=1.1 \mathrm{~Hz}, 1 \mathrm{H}, \mathrm{C}-6\right), 7.19\left(\mathrm{tt},{ }^{3} J_{\mathrm{HF}}=9.5 \mathrm{~Hz},{ }^{4} J_{\mathrm{HF}}=7.2 \mathrm{~Hz}, 1 \mathrm{H}, \mathrm{H}-4^{\prime}\right)$.

${ }^{13} \mathrm{C} \mathrm{NMR}\left(126 \mathrm{MHz}, \mathrm{CDCl}_{3}\right) \delta[\mathrm{ppm}]=161.4(\mathrm{C}-2), 147.3\left(\mathrm{dd},{ }^{1} J_{\mathrm{CF}}=248.3 \mathrm{~Hz},{ }^{3} J_{\mathrm{CF}}=13.5 \mathrm{~Hz}, \mathrm{C}-2^{\prime \dagger}\right), 146.2\left(\mathrm{~m}, \mathrm{C}-3^{\prime \dagger}\right)$, 137.4 (C-8a), 137.2 (C-4), 130.7 (C-7), 127.3 (C-5), 127.0 (C-3), 123.4 (C-6), 119.9 (C-4a), 116.2 (C-8), 112.1 (t, ${ }^{3} J_{C F}$ $\left.=20.2 \mathrm{~Hz}, \mathrm{C}-1^{\prime}\right), 107.9\left(\mathrm{t},{ }^{3} \mathrm{~J}_{\mathrm{CF}}=22.6 \mathrm{~Hz}, \mathrm{C}-4^{\prime}\right)$.

${ }^{\dagger}$ assignment is interconvertible

${ }^{19} \mathrm{~F}$ NMR $\left(376 \mathrm{MHz}, \mathrm{CDCl}_{3}\right) \delta[\mathrm{ppm}]=-131.8(\mathrm{~m}, 2 \mathrm{~F}),-137.2(\mathrm{~m}, 2 \mathrm{~F})$.

HRMS (+ESI): calc. for $\mathrm{C}_{15} \mathrm{H}_{8} \mathrm{OF}_{4} \mathrm{NS}[\mathrm{M}+\mathrm{H}]^{+}:$326.0257; found: 326.0254 .

IR (ATR) $\tilde{v}\left[\mathrm{~cm}^{-1}\right]=2994(w), 2930$ (w), 2889 (w), 2853 (w), 1651 (vs, C=O), 1559 (w, C=C), 1490 (vs), 1432 (m), 1235 (m, C-F), 1177 (w), $1033(w), 917(s), 894(w), 827$ (w, sp $\left.p^{2}-H\right), 750\left(m, s p^{2}\right.$ C-H), $713(w)$.

m.p. $=148-151^{\circ} \mathrm{C}$. 


\subsection{Single procedures}

2.3.1. Bis-(4-bromophenyl)-disulfide (SI-1)
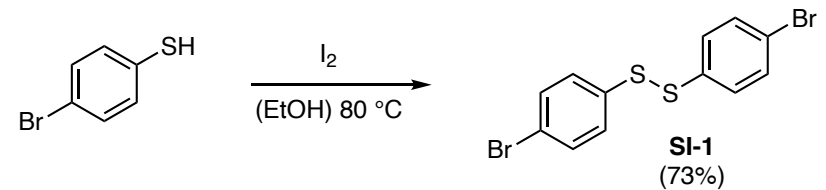

4-Bromothiophenol ( $3.53 \mathrm{~g}, 18.7 \mathrm{mmol}, 2.0$ equiv) was added to a solution of $\mathrm{I}_{2}$ ( $2.72 \mathrm{~g}, 10.7 \mathrm{mmol}, 1.15 \mathrm{equiv}$ ) in EtOH $(12 \mathrm{~mL})$ and the brown reaction mixture was heated to reflux for $1 \mathrm{~h}$. After cooling to ambient temperature, an aqueous solution of $\mathrm{Na}_{2} \mathrm{SO}_{3}(1 \mathrm{M}, 20 \mathrm{~mL})$, was added until the brown color has fainted entirely. The resulting white suspension was filtered over a sintered glass funnel and the residual solids were washed with $\mathrm{H}_{2} \mathrm{O}$. Drying under high vacuum afford the entitled disulfide $\mathbf{S I - 1}$ as a white crystalline solid $(2.56 \mathrm{~g}, 6.81 \mathrm{mmol}$, $73 \%)$.

${ }^{1} \mathrm{H}$ NMR $\left(500 \mathrm{MHz}, \mathrm{CDCl}_{3}\right) \delta[\mathrm{ppm}]=7.43\left(\right.$ virt d, $\left.{ }^{3} \mathrm{~J} \approx 8.6 \mathrm{~Hz}, 4 \mathrm{H}, \mathrm{H}-3\right), 7.33\left(\right.$ virt d, $\left.{ }^{3} \mathrm{~J} \approx 8.6 \mathrm{~Hz}, 4 \mathrm{H}, \mathrm{H}-2\right)$.

${ }^{13} \mathrm{C}$ NMR $\left(126 \mathrm{MHz}, \mathrm{CDCl}_{3}\right) \delta[\mathrm{ppm}]=136.1$ (C-1), 132.7 (C-3), 129.8 (C-2), 122.0 (C-4).

m.p. $=81-88^{\circ} \mathrm{C}$.

Spectral data matched those reported in the literature. ${ }^{5}$ 


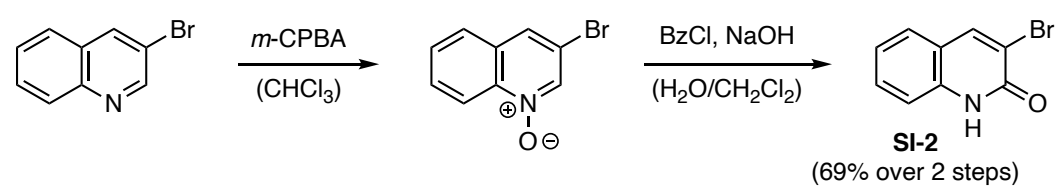

Following a procedure by Sabol et al., ${ }^{6} \mathrm{~m}$-CPBA ( $\geq 77 \%, 11.2 \mathrm{~g}, 49.9 \mathrm{mmol}, 1.15$ equiv) was added to a solution of 3-bromoquinoline (9.03 g, $43.4 \mathrm{mmol}, 1.0$ equiv) in $\mathrm{CH}_{2} \mathrm{Cl}_{2}(175 \mathrm{~mL}, 0.25 \mathrm{M})$ at $0{ }^{\circ} \mathrm{C}$. The reaction mixture was stirred for $5 \mathrm{~h}$ at $23^{\circ} \mathrm{C}$ before the reaction was quenched by careful addition of sat. aq. $\mathrm{NaHCO}_{3}$ solution (200 mL). The organic layer was separated, and the organic layer was extracted twice with $\mathrm{CH}_{2} \mathrm{Cl}_{2}(100 \mathrm{~mL})$. The combined organic layers were washed with brine, dried over $\mathrm{Na}_{2} \mathrm{SO}_{4}$ and the solvent removed in vacuo. The crude $\mathrm{N}$-oxide was dissolved in $\mathrm{CH}_{2} \mathrm{Cl}_{2}\left(65 \mathrm{~mL}\right.$ ) and solid $\mathrm{NaOH}$ (3.99 g, $99.7 \mathrm{mmol}, 2.3$ equiv) and $\mathrm{H}_{2} \mathrm{O}(130 \mathrm{~mL}$ ) were added sequentially at $0{ }^{\circ} \mathrm{C}$ whereupon a white solid precipitated. The reaction mixture was stirred vigorously for $5 \mathrm{~h}$ at $0{ }^{\circ} \mathrm{C}$ before it was filtered over a sintered glass funnel. The residual solids were washed with $\mathrm{H}_{2} \mathrm{O}(30 \mathrm{~mL}), \mathrm{CH}_{2} \mathrm{Cl}_{2}$ $(30 \mathrm{~mL})$ and eventually dried in vacuo to yield the entitled 3-bromoquinolone (SI-2) as an off-white powder (6.66 g, $29.7 \mathrm{mmol}, 69 \%)$.

${ }^{1} \mathbf{H}$ NMR $\left(500 \mathrm{MHz}, \mathrm{DMSO}-d_{6}\right) \delta[\mathrm{ppm}]=12.3$ (bs, $\left.1 \mathrm{H}, \mathrm{NH}\right), 8.50(\mathrm{~s}, 1 \mathrm{H}, \mathrm{H}-4), 7.67\left(\mathrm{dd},{ }^{3} \mathrm{~J}=7.9 \mathrm{~Hz},{ }^{4} \mathrm{~J}=1.4 \mathrm{~Hz}, 1 \mathrm{H}\right.$, $\mathrm{H}-5$ ), $7.54\left(\mathrm{ddd},{ }^{3} \mathrm{~J}=8.5 \mathrm{~Hz},{ }^{4} \mathrm{~J}=7.2,1.5 \mathrm{~Hz}, 1 \mathrm{H}, \mathrm{H}-7\right), 7.33\left(\mathrm{~d},{ }^{3} \mathrm{~J}=8.2 \mathrm{~Hz}, 1 \mathrm{H}, \mathrm{H}-8\right), 7.21\left(\mathrm{ddd},{ }^{3} \mathrm{~J}=8.0,7.2 \mathrm{~Hz},{ }^{4} \mathrm{~J}=\right.$ $1.1 \mathrm{~Hz}, 1 \mathrm{H}, \mathrm{H}-6)$.

${ }^{13} \mathrm{C}$ NMR $\left(126 \mathrm{MHz}\right.$, DMSO - $\left.d_{6}\right) \delta[\mathrm{ppm}]=157.7$ (C-2), 141.7 (C-4), 138.2 (C-8a), 130.8 (C-7), 127.4 (C-5), 122.4 (C6), 119.4 (C-4a), 117.1 (C-3), 115.2 (C-8).

m.p. $=242-250^{\circ} \mathrm{C}$.

Spectral data matched those reported in the literature. ${ }^{7}$ 
<smiles>O=c1[nH]c2ccccc2cc1Sc1ccccc1</smiles>

$7 a$

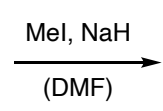

(DMF)

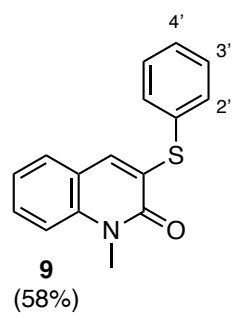

Mel (118 $\mu \mathrm{mol}, 1.89 \mathrm{mmol}, 2.0$ equiv) was added to a suspension of sulfide $7 \mathrm{a}$ ( $240 \mathrm{mg}, 947 \mu \mathrm{mol}, 1.0$ equiv) and $\mathrm{NaH}$ (60\% mineral oil, $56.8 \mathrm{mg}, 1.42 \mathrm{mmol}, 1.5$ equiv) in DMF (1.9 mL) and the reaction mixture was stirred for $24 \mathrm{~h}$ at ambient temperature. The reaction was quenched by addition of sat. aq. $\mathrm{NH}_{4} \mathrm{Cl}(20 \mathrm{~mL})$ and the aqueous layer was extracted thrice with EtOAc $(3 \times 15 \mathrm{~mL})$. The combined organic layers were washed with sat. aq. $\mathrm{NH}_{4} \mathrm{Cl}$ $(2 \times 50 \mathrm{~mL})$, brine $(2 \times 50 \mathrm{~mL})$ and dried over $\mathrm{Na}_{2} \mathrm{SO}_{4}$. The solvent was removed in vacuo and the crude material was subjected to FCC ( $20 \% \rightarrow 50 \% \mathrm{Et}_{2} \mathrm{O} / n$-pentane) to yield the entitled $\mathrm{N}$-methylated substrate 9 as a pale yellow solid (147 mg, $551 \mu \mathrm{mol}, 58 \%$ ).

$\boldsymbol{R}_{\mathbf{f}}(20 \%$ EtOAc/hexane): 0.26 .

${ }^{1} \mathrm{H}$ NMR $\left(500 \mathrm{MHz}, \mathrm{DMSO}-\mathrm{d}_{6}\right) \delta[\mathrm{ppm}]=7.58-7.48\left(\mathrm{~m}, 8 \mathrm{H}, \mathrm{H}-5, \mathrm{H}-7, \mathrm{H}-8, \mathrm{H}-\mathrm{2}^{\prime}, \mathrm{H}-3^{\prime}\right.$ and $\left.\mathrm{H}-4^{\prime}\right), 7.21\left(\mathrm{ddd},{ }^{3} \mathrm{~J}=8.0\right.$, $\left.6.2 \mathrm{~Hz},{ }^{4} J=2.0 \mathrm{~Hz}, 1 \mathrm{H}, \mathrm{H}-6\right), 7.17(\mathrm{~s}, 1 \mathrm{H}, \mathrm{H}-4), 3.70\left(\mathrm{~s}, 3 \mathrm{H}, \mathrm{CH}_{3}\right)$.

${ }^{13} \mathrm{C}$ NMR $\left(126 \mathrm{MHz}\right.$, DMSO-d $_{6} \delta$ [ppm] = 158.5 (C-2), 137.6 (C-8a), 134.2 (C-2'), 132.1 (C-4), 131.9 (C-3), 130.5 (C$\left.1^{\prime}\right), 130.1\left(\mathrm{C}-3^{\prime}\right), 129.8\left(\mathrm{C}-7^{\dagger}\right), 129.3\left(\mathrm{C}-4^{\prime+}\right), 127.6$ (C-5), 122.4 (C-6), 119.9 (C-4a), 114.7 (C-8), $29.9\left(\mathrm{CH}_{3}\right)$.

${ }^{+}$assignment is interconvertible

HRMS (+ESI): calc. for $\mathrm{C}_{16} \mathrm{H}_{14} \mathrm{ONS}$ [M+H]+: 268.0791; found: 268.0792 .

IR (ATR) $\tilde{v}\left[\mathrm{~cm}^{-1}\right]=3054$ (w), 2938 (w), 1626 (vs, C=0), 1589 (vs, C=C), 1456 (s), 1296 (m), 1220 (s), 1070 (s), 952 $(m), 829\left(m, s^{2} C-H\right), 749$ (vs, sp $\left.{ }^{2} C-H\right)$.

m.p. $=131-134^{\circ} \mathrm{C}$. 

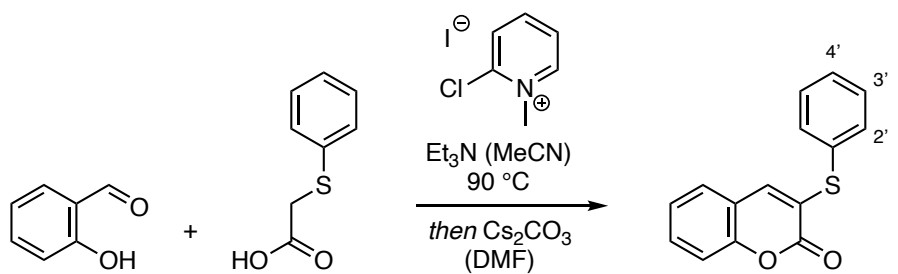

10

(30\%)

In a modified procedure by Mashraqui et al., ${ }^{8}$ (phenylthio)acetic acid (740 mg, $4.40 \mathrm{mmol}, 1.1$ equiv), salicylaldehyde (488 mg, $4.00 \mathrm{mmol}, 1.0$ equiv) and $\mathrm{Et}_{3} \mathrm{~N}$ (1.39 mL, $10.0 \mathrm{mmol}, 2.5$ equiv) were added sequentially to a suspension of 2-chloro- $N$-methylpyridinium iodide ( $2.04 \mathrm{mg}, 8.00 \mathrm{mmol}, 2.0$ equiv) in MeCN $(40 \mathrm{~mL}, 0.1 \mathrm{M})$. The reaction mixture was heated to reflux for $2 \mathrm{~h}$ before the solvent was removed in vacuo. Diluted aqueous $\mathrm{HCl}(1 \mathrm{M}, 15 \mathrm{~mL})$ was added and the aqueous layer was extracted thrice with $\mathrm{CH}_{2} \mathrm{Cl}_{2}(3 \times 20 \mathrm{~mL})$. The combined organic layers were washed with brine $(50 \mathrm{~mL})$ and dried over $\mathrm{Na}_{2} \mathrm{SO}_{4}$. The solvent was removed in vacuo and the residual brown oil was dissolved in DMF (40 mL, $0.1 \mathrm{M}) . \mathrm{Cs}_{2} \mathrm{CO}_{3}(6.52 \mathrm{~g}, 20.0 \mathrm{mmol}, 5.0$ equiv) was added in one portion and the reaction mixture was stirred for $16 \mathrm{~h}$ at $23^{\circ} \mathrm{C}$. The reaction was quenched by addition of sat. aq. $\mathrm{NH}_{4} \mathrm{Cl}$ solution $(100 \mathrm{~mL})$. The aqueous layer was extracted thrice with EtOAc $(3 \times 50 \mathrm{~mL})$ and the combined organic layers were washed with sat. aq. $\mathrm{NH}_{4} \mathrm{Cl}(2 \times 100 \mathrm{~mL})$, brine $(2 \times 100 \mathrm{~mL})$ and dried over $\mathrm{Na}_{2} \mathrm{SO}_{4}$. After removal of all volatiles in vacuo the crude material was subjected to $\mathrm{FCC}\left(30 \% \rightarrow 50 \% \mathrm{CH}_{2} \mathrm{Cl}_{2} / n\right.$ pentane) to yield the entitled coumarin 10 as a light yellow solid (301 mg, $1.18 \mathrm{mmol}, 30 \%$ ).

$\boldsymbol{R}_{\mathbf{f}}(20 \%$ EtOAc/hexanes): 0.50 .

${ }^{1} \mathrm{H}$ NMR $\left(500 \mathrm{MHz}, \mathrm{DMSO}-d_{6}\right) \delta[\mathrm{ppm}]=7.57\left(\mathrm{~m}, 4 \mathrm{H}, \mathrm{H}-5, \mathrm{H}-7, \mathrm{H}-2^{\prime \dagger}\right), 7.54-7.48\left(\mathrm{~m}, 4 \mathrm{H}, \mathrm{H}-3, \mathrm{H}-3^{\prime \dagger}, \mathrm{H}-4^{\prime}\right), 7.44-$ $7.40(\mathrm{~m}, 1 \mathrm{H}, \mathrm{H}-8), 7.31\left(\mathrm{td},{ }^{3} \mathrm{~J}=7.5 \mathrm{~Hz},{ }^{4} \mathrm{~J}=1.1 \mathrm{~Hz}, 1 \mathrm{H}, \mathrm{H}-6\right)$.

${ }^{13} \mathrm{C}$ NMR $\left(126 \mathrm{MHz}, \mathrm{DMSO}-d_{6}\right) \delta[\mathrm{ppm}]=158.2$ (C-2), 151.9 (C-8a), 138.1 (C-4), $133.3\left(\mathrm{C}-3^{\prime \dagger}\right), 131.3$ (C-7), 130.2 $\left(C-2^{\prime \dagger}\right), 129.9\left(C-3^{\ddagger}\right), 129.3\left(C-4^{\prime}\right), 127.6(C-5), 126.7\left(C-1^{\prime \ddagger}\right), 124.9$ (C-6), 119.2 (C-4a), 116.1 (C-8).

${ }^{+} \ddagger$ assignment is interconvertible

HRMS (+ESI): calc. for $\mathrm{C}_{15} \mathrm{H}_{10} \mathrm{O}_{2} \mathrm{NaS}[\mathrm{M}+\mathrm{Na}]^{+}$: 277.0294; found: 277.0284 .

IR (ATR) $\tilde{v}\left[\mathrm{~cm}^{-1}\right]=3060$ (w), 1718, (vs, C=O), 1701 (vs, C=O), 1608 (s), 1557 (w, C=C), 1474 (w), 1440 (m), 1276 (m), 1249 (w), 1164 (s, C-O), 1120 (m), 978 (s), 920 (w), 828 (w, sp ${ }^{2}$ C-H), 750 (vs, sp² C-H), 728 (s, sp C $^{2}$ ).

m.p. $=121-124^{\circ} \mathrm{C}$ 


\subsection{Optimization of the enantioselective sulfoxidation with sulfide 7a}
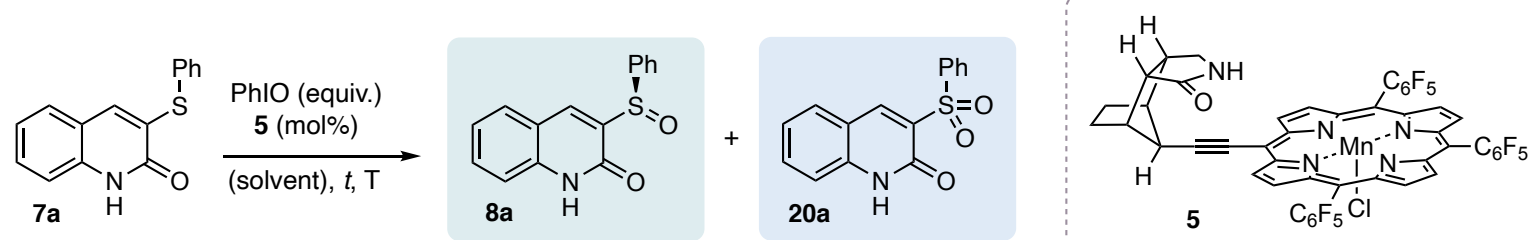

Table S1: Reaction was performed under the indicated conditions at $\mathrm{T}=0{ }^{\circ} \mathrm{C}$ and initiated by addition of the catalyst to a precooled suspension of the oxidant iodosobenene $(\mathrm{PhIO})$ and $7 \mathrm{a}(100 \mu \mathrm{mol})$ in the indicated solvent. The reaction was terminated by removal of all volatiles under reduced pressure after $t=4 \mathrm{~h}$. All yields refer to isolated material. ${ }^{a}$ Equivalents of PhIO relative to quinolone 7a. ${ }^{b}$ Enantiomeric excess of the sulfoxide 8 a as determined by HPLC analysis on a chiral stationary phase. ${ }^{c}$ Conversion as well as the yield of sulfone 20a was determined by re-isolation of a mixture of 7a and $\mathbf{2 0 a}$. Relative abundance is based on ${ }^{1} \mathrm{H}$ NMR spectroscopic analysis (relative integration of the $\mathrm{H}-4$ proton, $\delta[\mathrm{ppm}]=8.97 \mathrm{ppm}$ [sulfone], $7.22 \mathrm{ppm}$ [sulfide]). ${ }^{d}$ Reaction time was $t=15 \mathrm{~h} .{ }^{e}$ Reaction time was $t=1 \mathrm{~h} .{ }^{f}$ Reaction was run at $\mathrm{T}=-15^{\circ} \mathrm{C} .{ }^{g}$ In preliminary experiments, the sulfoxidation of related substrates was investigated using conditions indicated in entry \#2.

\begin{tabular}{|c|c|c|c|c|c|c|c|c|c|}
\hline$\#$ & $\begin{array}{c}\mathrm{PhIO}^{a} \\
\text { [equiv] }\end{array}$ & $\begin{array}{c}\mathbf{5} \\
{[\mathrm{mol} \%]}\end{array}$ & solv. & $\begin{array}{l}\text { conc. } \\
{[\mathrm{mM}]}\end{array}$ & $8 a[\%]$ & $\% e e^{b}$ & $20 \mathrm{a}[\%]^{c}$ & $\begin{array}{c}\text { conv.c }^{c} \\
{[\%]}\end{array}$ & related substrates $g$ \\
\hline 1 & 1.5 & 0.5 & $\mathrm{CH}_{2} \mathrm{Cl}_{2}$ & 10 & 64 & 79 & 26 & 95 & \\
\hline 2 & 1.1 & 0.5 & $\mathrm{CH}_{2} \mathrm{Cl}_{2}$ & 10 & 62 & 85 & 16 & 87 & \\
\hline 3 & 1.1 & 1.0 & $\mathrm{CH}_{2} \mathrm{Cl}_{2}$ & 10 & 60 & 85 & 16 & 79 & \\
\hline 4 & 1.1 & 0.25 & $\mathrm{CH}_{2} \mathrm{Cl}_{2}$ & 10 & 57 & 86 & 6 & 63 & \\
\hline 5 & 1.5 & 0.25 & $\mathrm{CH}_{2} \mathrm{Cl}_{2}$ & 10 & 61 & 72 & 10 & 88 & $\begin{array}{c}(42 \%) \\
40 \% \text { ee }\end{array}$ \\
\hline $6^{d}$ & 1.1 & 0.5 & $\mathrm{CH}_{2} \mathrm{Cl}_{2}$ & 10 & 59 & 79 & 15 & 82 & \\
\hline $7^{e}$ & 1.1 & 0.5 & $\mathrm{CH}_{2} \mathrm{Cl}_{2}$ & 10 & 45 & 62 & 10 & 55 & \\
\hline 8 & 1.1 & 0.5 & $\mathrm{CH}_{2} \mathrm{Cl}_{2}$ & 7 & 61 & 82 & 9 & 75 & \\
\hline 9 & 1.1 & 0.5 & $\mathrm{CH}_{2} \mathrm{Cl}_{2}$ & 20 & 60 & 78 & 14 & 75 & \\
\hline $10^{f}$ & 1.1 & 0.5 & $\mathrm{CH}_{2} \mathrm{Cl}_{2}$ & 10 & 48 & 56 & 8 & 64 & $21 \%)$ \\
\hline 11 & 1.1 & 0.5 & $\mathrm{CHCl}_{3}$ & 10 & 63 & 84 & 10 & 77 & \\
\hline 12 & 1.1 & 0.5 & DCE & 10 & 37 & 62 & 19 & 62 & \\
\hline 13 & 1.1 & 0.5 & PhMe & 10 & 29 & 65 & 5 & 40 & \\
\hline 14 & 1.1 & 0.5 & $\mathrm{PhF}$ & 10 & 38 & 68 & 8 & 61 & \\
\hline 15 & 1.1 & 0.5 & $\mathrm{MeCN}$ & 10 & 24 & 7 & 32 & 60 & $6 \%$ \\
\hline 16 & 1.3 & 0.5 & $\mathrm{CHCl}_{3}$ & 10 & 71 & 81 & 13 & 85 & \\
\hline 17 & $2 \times 0.65$ & 0.25 & $\mathrm{CHCl}_{3}$ & 10 & 68 & 83 & 15 & 86 & \\
\hline 18 & $2 \times 0.65$ & 0.5 & $\mathrm{CHCl}_{3}$ & 10 & 67 & 90 & 19 & 79 & \\
\hline 19 & $2 \times 0.65$ & 1.0 & $\mathrm{CHCl}_{3}$ & 10 & 75 & 92 & 16 & 91 & \\
\hline 20 & $2 \times 0.75$ & 0.5 & $\mathrm{CHCl}_{3}$ & 10 & 75 & 90 & 16 & 91 & H \\
\hline 21 & $2 \times 0.75$ & 1.0 & $\mathrm{CHCl}_{3}$ & 10 & 68 & 90 & 24 & 97 & $\begin{array}{c}(50 \%) \\
53 \% \text { ee }\end{array}$ \\
\hline 22 & $3 \times 0.50$ & 1.0 & $\mathrm{CHCl}_{3}$ & 10 & 72 & 93 & 24 & 96 & \\
\hline
\end{tabular}


Several trends during the optimization study might seem surprising at a first glance and perhaps require an elaborate explanation. The presented study commenced with substrate $7 \mathrm{a}$ and manganese complex $\mathbf{5}$ (0.5 mol\%) using previously reported conditions. ${ }^{9}$ lodosobenzene (PhIO) was used as a stoichiometric oxidant and the reaction was run for 4 hat $0{ }^{\circ} \mathrm{C}$ in $\mathrm{CH}_{2} \mathrm{Cl}_{2}$. Sulfoxide 8 a was isolated in reasonable yield (64\%) as well as encouraging enantioselectivity $(79 \%$ ee) (Table S1, entry 1$)$. Lowering the amount of oxidant slightly increased the enantiomeric ratio of $\mathbf{8 a}(85 \%$ ee), while concomitantly avoiding excessive over-oxidation to sulfone 20 a (entry 2). Increasing or reducing the catalyst loading had almost no effect on the product formation (entry 3 and 4), but it was notable that the turnover number peaked to up to 275 turnovers. It was envisioned, that using more oxidant could potentially increase the yield at a lower catalyst loading (entry 5), however, a significantly diminished enantioselectivity was observed ( $72 \%$ ee). At this stage, control experiments were run with sulfide 7 a and sulfoxide rac-8a under identical conditions ( 1.5 equiv of PhIO), but in the absence of catalyst 5 . No oxidation from sulfide $7 \mathbf{7}$ to sulfoxide $\mathbf{8 a}$, nor oxidation from sulfoxide $\mathbf{8 a}$ to sulfone $\mathbf{2 0 a}$ was observed, clearly suggesting that the oxidation is exclusively catalyzed by the manganese porphyrin $\mathbf{5}$. We continued by altering the reaction time at a catalyst loading of 0.5 mol\% (entry 6 and 7), but no progress in terms of yield or enantioselectivity was observed, nor did variation of the reaction concentration help to improve the reaction (entry 8 and 9). Surprisingly, lowering the temperature to $-15{ }^{\circ} \mathrm{C}$ (entry 10$)$ significantly deteriorated the selectivity $(56 \%$ ee), which could potentially be rationalized by a distorted binding mode of the substrate 7 a to catalyst $\mathbf{5}$. Upon screening of numerous aprotic, chlorinated and aromatic solvents (entry 10-15), it was discovered that only $\mathrm{CHCl}_{3}$ performed equally well and most importantly even improved the chemoselectivity. In particular, the sulfoxide to sulfone ratio 8a:20a increased from less than 4:1 (entry 2) to more than 6:1 (entry 11), while maintaining high yield and satisfying enantioselectivity. It was a crucial observation and prompted us to increase the amount of oxidant to confirm that this high chemoselectivity could be warranted with an enhanced substrate turnover. As anticipated, using 1.3 equivalents of PhIO improved the yield to $71 \%$ yield, while the selectivity of the sulfoxidation was barely affected (entry 16).

Careful analysis of the entire set of conditions led to two fundamental consideration. Firstly, a high concentration of the oxidant led to a diminished enantioselectivity ( $c f$. entry 1 and 2). Secondly, increasing the catalyst loading caused a retarded conversion (cf. entry 2 and 3 ) and reduce catalytic turnovers (compared to entry 4) most likely due to oxidative degradation of the catalyst 5. With this in mind, it was envisioned that keeping the oxidant concentration low by a portion wise addition could possibly increase the lifetime of the catalyst and moreover improve the selectivity. When the oxidant was added in two portions ( $2 \times 0.65$ equiv) at a varying catalyst loading (entry 17 and 18), 8a was finally isolated with notably higher selectivity (90\% ee) and a promising yield of $67 \%$ (entry 18 ). Given that only $79 \%$ of the substrate 7 a was converted, the catalyst loading was increased to 1.0 mol\% whereupon the yield improved to $75 \%$ (91\% conversion) with excellent enantioselectivity (92\% ee) (entry 19). Adding the oxidant in two portions of 0.75 equiv did not improve the reaction (entry 20 and 21). Finally, the conversion was almost pushed to completion when three portions of the oxidant were added ( $3 \times 0.5$ equiv), however, under these conditions significant over-oxidation to the sulfone 9a became evident (entry 22). Ultimately, the conditions indicated in entry 19 were identified as a best compromise in terms of yield, chemoselectivity and most importantly enantioselectivity. 


\subsection{General procedure 3 (GP3): enantioselective sulfoxidation of sulfides 7}<smiles>O=c1[nH]c2ccccc2cc1SP</smiles>

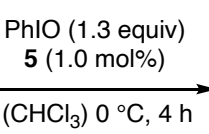

$\left(\mathrm{CHCl}_{3}\right) 0^{\circ} \mathrm{C}, 4 \mathrm{~h}$

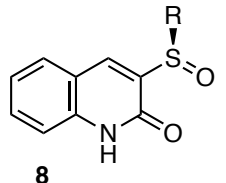

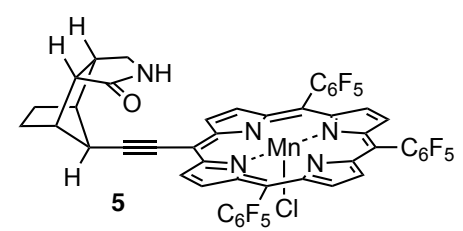

5

PhIO (14.3 mg, $0.65 \mu \mathrm{mol}, 0.65$ equiv) was added to a solution of the chiral manganese porphyrin catalyst 5 (5.0 mM in $\mathrm{CHCl}_{3}, 200 \mu \mathrm{L}, 1.00 \mu \mathrm{mol} 1.00$ mol\%) and the corresponding sulfide 7 (100 $\mu \mathrm{mol}, 1.0$ equiv) in $\mathrm{CHCl}_{3}$ $(10 \mathrm{~mL}, 10 \mathrm{~mm})$ at $0{ }^{\circ} \mathrm{C}$ affording a green suspension. After $1 \mathrm{~h}$ a second portion of PhIO (14.3 $\mathrm{mg}, 0.65 \mu \mathrm{mol}$, 0.65 equiv) was added and the reaction was stirred for further $3 \mathrm{~h}$ at $0{ }^{\circ} \mathrm{C}$ (cumulative reaction time: $4 \mathrm{~h}$ ) at which point the solvent was removed in vacuo. The crude material was purified by automated FCC (cf. general experimental procedure) to yield the entitled enantiomerically enriched sulfoxide 8.

\subsection{1. (R)-3-(phenylsulfinyl)-2-quinolone (8a)}<smiles>O=c1[nH]c2ccccc2cc1S(=O)c1ccccc1</smiles>

Following GP3 the entitled sulfoxide 8a was obtained as an off-white solid $(20.2 \mathrm{mg}$, $75.0 \mu \mathrm{mol}, 75 \%)$ accompanied by a mixture of sulfone $20 \mathrm{a}(4.53 \mathrm{mg}, 15.9 \mu \mathrm{mol}, 16 \%)$ and recovered starting material $7 \mathrm{a}(2.17 \mathrm{mg}, 8.57 \mu \mathrm{mol}, 9 \%, 92 \%$ ee $)$.

Scale up experiment: The chiral manganese porphyrin complex $5\left(5.0 \mathrm{mM}\right.$ in $\mathrm{CHCl}_{3}, 2.00 \mathrm{~mL}$, $10.0 \mu \mathrm{mol}, 1.0 \mathrm{~mol} \%)$ was added to a solution substrate $7 \mathrm{a}\left(253 \mathrm{mg}, 1.00 \mathrm{mmol}, 1.0\right.$ equiv) in $\mathrm{CHCl}_{3}(100 \mathrm{~mL})$ and the reaction was stirred for $20 \mathrm{~min}$ at $0{ }^{\circ} \mathrm{C}$. PhlO (143 mg, $0.65 \mathrm{mmol}, 0.65$ equiv) was added in one portion and after $1 \mathrm{~h}$ the second portion of $\mathrm{PhIO}(143 \mathrm{mg}, 0.65 \mathrm{mmol}, 0.65$ equiv) was added. After a total reaction time of 6 $h$, the reaction was quenched by addition of $1.0 \mathrm{M} \mathrm{Na}_{2} \mathrm{SO}_{3}$ solution $(50 \mathrm{~mL})$ and the organic layer was separated. The aqueous layer was extracted twice with $\mathrm{CH}_{2} \mathrm{Cl}_{2}(2 \times 50 \mathrm{~mL})$ and the combined organic layers were washed with brine and dried over $\mathrm{Na}_{2} \mathrm{SO}_{4}$. After removal of all volatiles in vacuo, the crude material was purified by automated flash chromatography under standard conditions ( $c f$. general experimental procedure) in combination with a Biotage ${ }^{\circledR}$ pre-packed silica cartridge (Biotage ${ }^{\circledR}$ Sfär Silica D Duo $60 \mu \mathrm{m} 50$ g, manufacturer number FSRD-0445-0050) to yield the entitled sulfoxide 8 a as an off-white solid (189 mg, $0.70 \mathrm{mmol}, 70 \%, 96 \%$ ee).

Kinetic resolution experiment: $\mathrm{PhlO}(14.3 \mathrm{mg}, 0.65 \mu \mathrm{mol}, 0.65$ equiv) was added to a solution of the chiral manganese porphyrin catalyst $5\left(5.0 \mathrm{mM}\right.$ in $\left.\mathrm{CHCl}_{3}, 200 \mu \mathrm{L}, 1.00 \mu \mathrm{mol} 1.00 \mathrm{~mol} \%\right)$ and sulfoxide rac-8a (26.9 mg, $100 \mu \mathrm{mol}, 1.0$ equiv) in $\mathrm{CHCl}_{3}(10 \mathrm{~mL}, 10 \mathrm{~mm})$ at $0{ }^{\circ} \mathrm{C}$ affording a green suspension. The reaction was stirred for $4 \mathrm{~h}$, at $0^{\circ}$ at which point the solvent was removed in vacuo. The crude material was purified by automated FCC (cf. general experimental procedure) to yield sulfoxide ent-8 (19.6 mg, $72.8 \mu \mathrm{mol}, 73 \%,-11 \%$ ee) and sulfoxide 20a (6.00 mg, $21.0 \mu \mathrm{mol}, 21 \%)$ both as off-white solids. 
$\boldsymbol{R}_{\mathbf{f}}\left(30 \%\right.$ EtOAc $\left./ \mathrm{CH}_{2} \mathrm{Cl}_{2}\right): 0.31$.

${ }^{1} \mathrm{H}$ NMR $\left(500 \mathrm{MHz}, \mathrm{MeOD}-d_{4}\right) \delta[\mathrm{ppm}]=8.51(\mathrm{~s}, 1 \mathrm{H}, \mathrm{H}-4), 7.91-7.80\left(\mathrm{~m}, 3 \mathrm{H}, \mathrm{H}-5, \mathrm{H}-2^{\prime}\right), 7.63$ (ddd, ${ }^{3} \mathrm{~J}=8.5,7.2 \mathrm{~Hz}$, $\left.{ }^{4} J=1.4 \mathrm{~Hz}, 1 \mathrm{H}\right), 7.58-7.49\left(\mathrm{~m}, 3 \mathrm{H}, \mathrm{H}-3^{\prime}, \mathrm{H}-4^{\prime}\right), 7.42-7.29(\mathrm{~m}, 2 \mathrm{H}, \mathrm{H}-6, \mathrm{H}-8)$.

${ }^{13} \mathrm{C}$ NMR $\left(126 \mathrm{MHz}, \mathrm{MeOD}-d_{4}\right) \delta[\mathrm{ppm}]=160.1$ (C-2), 144.3 (C-1'), 140.5 (C-8a), 138.7 (C-4), 137.3 (C-3), 133.6 (C7), 133.1 (C-4'), 130.5 (C-3'), 130.3 (C-5), 127.1 (C-2'), 124.5 (C-6), 120.4 (C-4a), 116.8 (C-8).

HRMS (+ESI): calc. for $\mathrm{C}_{15} \mathrm{H}_{12} \mathrm{O}_{2} \mathrm{NS}[\mathrm{M}+\mathrm{H}]^{+}:$:270.0583; found: 270.0584 .

IR (ATR) $\tilde{v}\left[\mathrm{~cm}^{-1}\right]=3186(\mathrm{w}, \mathrm{N}-\mathrm{H}), 2981$ (w), 2923 (w), 1646 (vs, C=O), 1556 (w, C=C), 1468 (w), 1428 (w), 1377 (w), $1251(w), 1204(w), 1154(w), 1077(m), 1041$ (s, S=O), $957(w), 756$ (s, sp² C-H), 732 (m, sp² C-H), $687(m)$.

m.p. $=273-276^{\circ} \mathrm{C}$

Specific rotation: $[a]_{D}^{25}=+82.0\left(c=1.0\right.$, DMSO- $d_{6}, 96 \%$ ee $)$.

Chiral HPLC: $96 \%$ ee $\left[{ }^{\circ} \mathrm{CHIRALPAK} \mathrm{AD-H}, 20{ }^{\circ} \mathrm{C}, 20 \%{ }^{i} \mathrm{PrOH} / \mathrm{n}\right.$-heptane, $1 \mathrm{~mL} / \mathrm{min}, 210 \mathrm{~nm}, \mathrm{t}_{\mathrm{R}}=15.7 \mathrm{~min}$ (major), $18.0 \mathrm{~min}$ (minor)].

\subsubsection{3-(Phenylsulfonyl)-2-quinolone (20a)}

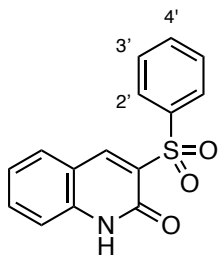

$\boldsymbol{R}_{\mathbf{f}}\left(20 \% \mathrm{EtOAc} / \mathrm{CH}_{2} \mathrm{Cl}_{2}\right): 0.68$.

${ }^{1} \mathrm{H}$ NMR $\left(500 \mathrm{MHz}, \mathrm{DMSO}-d_{6}\right) \delta[\mathrm{ppm}]=12.2(\mathrm{bs}, 1 \mathrm{H}, \mathrm{NH}), 8.97(\mathrm{~s}, 1 \mathrm{H}, \mathrm{H}-4), 8.04-7.99(\mathrm{~m}, 3 \mathrm{H}$, $\left.\mathrm{H}-5, \mathrm{H}-2^{\prime}\right), 7.73-7.65\left(\mathrm{~m}, 2 \mathrm{H}, \mathrm{H}-7, \mathrm{H}-4^{\prime}\right), 7.61\left(\mathrm{t},{ }^{3} \mathrm{~J}=7.7 \mathrm{~Hz}, 2 \mathrm{H}, \mathrm{H}-3^{\prime}\right), 7.35\left(\mathrm{dd},{ }^{3} \mathrm{~J}=8.4 \mathrm{~Hz},{ }^{4} \mathrm{~J}=\right.$ $0.9 \mathrm{~Hz}, 1 \mathrm{H}, \mathrm{H}-8$ ), 7.30 (ddd, $\left.{ }^{3} J=8.1,7.1 \mathrm{~Hz},{ }^{4} J=1.1 \mathrm{~Hz}, 1 \mathrm{H}, \mathrm{H}-6\right)$.

${ }^{13} \mathrm{C}$ NMR (126 MHz, DMSO-d (1) $\delta$ [ppm] = 156.4 (C-2), 144.7 (C-4), 141.1 (C-8a), $139.6\left(\mathrm{C}-1^{\prime}\right), 134.1\left(\mathrm{C}-7^{\dagger}\right), 133.7$ $\left(C^{\prime}-4^{\prime \dagger}\right), 130.7$ (C-5), 130.6 (C-3), 129.0 (C.3'), 128.4 (C-2'), 122.8 (C-6), 117.2 (C-4a), 115.4 (C-8).

${ }^{\dagger}$ assignment is interconvertible

m.p. $\geq 297-300^{\circ} \mathrm{C}$

Spectral data matched those reported in the literature. ${ }^{10}$

2.5.3. (R)-3-(p-Tolylsulfinyl)-2-quinolone (8b)<smiles>Cc1ccc(S(=O)c2cc3ccccc3[nH]c2=O)cc1</smiles>

Following GP3 the entitled sulfoxide $\mathbf{8 b}$ was obtained as an off-white solid $(19.0 \mathrm{mg}$, $67.1 \mu \mathrm{mol}, 67 \%)$

$\boldsymbol{R}_{\mathbf{f}}\left(30 \% \mathrm{EtOAc} / \mathrm{CH}_{2} \mathrm{Cl}_{2}\right): 0.28$.

${ }^{1} \mathrm{H}$ NMR $\left(500 \mathrm{MHz}, \mathrm{MeOD}-d_{4}\right) \delta[\mathrm{ppm}]=8.50(\mathrm{~s}, 1 \mathrm{H}, \mathrm{H}-4)$, 7.90-7.86 (m, 1H, H-5), 7.74-7.69 (m, $\left.2 \mathrm{H}, \mathrm{H}-2^{\prime}\right), 7.63\left(\mathrm{ddd},{ }^{3} \mathrm{~J}=8.5,7.2 \mathrm{~Hz},{ }^{4} \mathrm{~J}=1.4 \mathrm{~Hz}, 1 \mathrm{H}, \mathrm{H}-7\right), 7.39-7.31\left(\mathrm{~m}, 4 \mathrm{H}, \mathrm{H}-6, \mathrm{H}-8\right.$ and $\left.\mathrm{H}-3^{\prime}\right), 2.38\left(\mathrm{~s}, 3 \mathrm{H}, \mathrm{CH}_{3}\right)$.

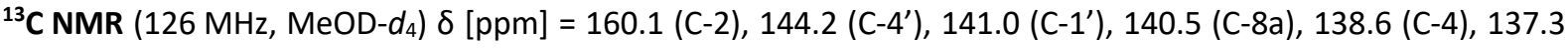
(C-3), 133.6 (C-7), 131.1 (C-3'), 130.2 (C-5), 127.3 (C-2'), 124.5 (C-6), 120.4 (C-4a), 116.8 (C-8), $21.4\left(\mathrm{CH}_{3}\right)$. 
HRMS (+ESI): calc. for $\mathrm{C}_{16} \mathrm{H}_{14} \mathrm{O}_{2} \mathrm{NS}[\mathrm{M}+\mathrm{H}]^{+}:$284.0740; found: 284.0748 .

IR (ATR) $\tilde{v}\left[\mathrm{~cm}^{-1}\right]=3186(\mathrm{w}, \mathrm{N}-\mathrm{H}), 2981\left(\mathrm{w}, \mathrm{sp}^{3} \mathrm{C}-\mathrm{H}\right), 2925\left(\mathrm{w}, \mathrm{sp}^{3} \mathrm{C}-\mathrm{H}\right), 1648$ (vs, C=O), $1558(\mathrm{w}, \mathrm{C}=\mathrm{C}), 1492(\mathrm{w})$, $1429(w), 1377(w), 1251(w), 1204(w), 1079(w), 1044(m, S=0), 956(w), 807$ (w, sp $\left.p^{2} C-H\right), 753\left(m, s p^{2} C-H\right)$

m.p. $=234-237^{\circ} \mathrm{C}$.

Specific rotation: $[a]_{D}^{25}=+46.0\left(\mathrm{c}=1.0, \mathrm{DMSO}-d_{6}, 92 \% e e\right)$.

Chiral HPLC: $92 \%$ ee $\left[{ }^{\circ} \mathrm{CHIRALPAK} \mathrm{AD-H}, 20{ }^{\circ} \mathrm{C}, 30 \%{ }^{i} \mathrm{PrOH} / n\right.$-heptane, $1 \mathrm{~mL} / \mathrm{min}, 210 \mathrm{~nm}, \mathrm{t}_{\mathrm{R}}=10.4 \mathrm{~min}$ (major), $12.0 \mathrm{~min}$ (minor)].

2.5.4. (R)-3-((4-Fluorophenyl)sulfinyl)-2-quinolone (8c)

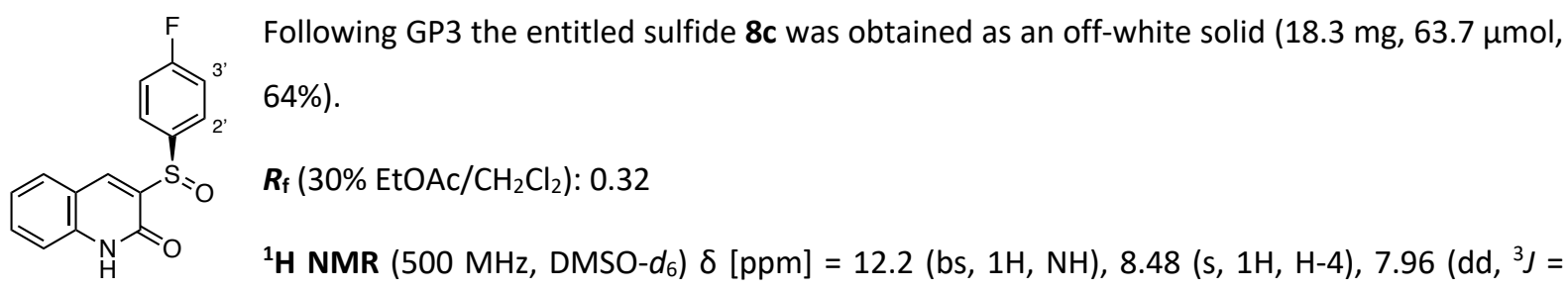
$\left.7.9 \mathrm{~Hz},{ }^{4} J=1.4 \mathrm{~Hz}, 1 \mathrm{H}, \mathrm{H}-5\right), 7.89-7.83\left(\mathrm{~m}, 2 \mathrm{H}, \mathrm{H}-2^{\prime}\right), 7.61$ (ddd, $\left.{ }^{3} J=8.5,7.1 \mathrm{~Hz},{ }^{4} J=1.5 \mathrm{~Hz}, 1 \mathrm{H}, \mathrm{H}-7\right), 7.39-7.34(\mathrm{~m}$, $\left.3 \mathrm{H}, \mathrm{H}-8, \mathrm{H}-3^{\prime}\right), 7.28\left(\mathrm{ddd},{ }^{3} \mathrm{~J}=8.1,7.2 \mathrm{~Hz},{ }^{4} \mathrm{~J}=1.1 \mathrm{~Hz}, 1 \mathrm{H}, \mathrm{H}-6\right)$.

${ }^{13} \mathrm{C}$ NMR $(126 \mathrm{MHz} \text {, DMSO-d })_{6} \delta[\mathrm{ppm}]=163.7$ (d, $\left.{ }^{1} J_{\mathrm{CF}}=248.9 \mathrm{~Hz}, \mathrm{C}-4^{\prime}\right), 157.9$ (C-2), 139.9 (C-1'), 139.2 (C-8a), 136.9 (C-3), 136.6 (C-4), 132.1 (C-7), 129.2 (C-5), 128.3 (d, ${ }^{3} \mathrm{~J}_{\mathrm{CF}}=9.1 \mathrm{~Hz}, \mathrm{C}-2^{\prime}$ ), 122.7 (C-6), 118.4 (C-4a), 116.4 (d, $\left.{ }^{2} J_{C F}=22.6 \mathrm{~Hz}, \mathrm{C}-3^{\prime}\right), 115.6(\mathrm{C}-8)$.

${ }^{19} \mathrm{~F} \mathrm{NMR}\left(376 \mathrm{MHz}, \mathrm{DMSO}-d_{6}\right) \delta[\mathrm{ppm}]=-108.6\left(\mathrm{tt},{ }^{3} \mathrm{~J}=9.6 \mathrm{~Hz},{ }^{4} \mathrm{~J}=5.2 \mathrm{~Hz}, 1 \mathrm{~F}\right)$.

HRMS (+ESI): calc. for $\mathrm{C}_{15} \mathrm{H}_{10} \mathrm{O}_{2} \mathrm{FNaNS}[\mathrm{M}+\mathrm{Na}]^{+}$: 310.0308 ; found: 310.0303 .

IR (ATR) $\tilde{v}\left[\mathrm{~cm}^{-1}\right]=3184(\mathrm{w}, \mathrm{N}-\mathrm{H}), 3065$ (w), $2926(\mathrm{w}), 2889(\mathrm{w}), 2852(\mathrm{w}), 1647$ (vs, C=O), $1588(\mathrm{~m}, \mathrm{C}=\mathrm{C}), 1490$ (s), $1429(w), 1228(m, C-F), 1153(m), 1079(m), 1047(m, S=O), 955(w), 831\left(m, s p^{2} C-H\right), 753\left(m, s p^{2}\right.$ C-H), 736 (w, sp $\left.{ }^{2} \mathrm{C}-\mathrm{H}\right)$.

m.p. $=247-250^{\circ} \mathrm{C}$.

Specific rotation: $[a]_{D}^{25}=+56.0\left(\mathrm{c}=1.0, \mathrm{DMSO}-d_{6}, 92 \%\right.$ ee $)$.

Chiral HPLC: $92 \%$ ee $\left[{ }^{\odot} \mathrm{CHIRALPAK} A D-\mathrm{H}, 20{ }^{\circ} \mathrm{C}, 10 \%{ }^{i} \mathrm{PrOH} / \mathrm{n}\right.$-heptane, $1 \mathrm{~mL} / \mathrm{min}, 210 \mathrm{~nm}, \mathrm{t}_{\mathrm{R}}=37.2 \mathrm{~min}$ (major), $40.2 \min (\operatorname{minor})]$. 
Cl Following GP3 the entitled sulfoxide $8 \mathrm{~d}$ was obtained as an off-white solid $(20.0 \mathrm{mg}$, $65.8 \mu \mathrm{mol}, 66 \%)$.

$\boldsymbol{R}_{\mathbf{f}}\left(30 \% \mathrm{EtOAC} / \mathrm{CH}_{2} \mathrm{Cl}_{2}\right): 0.35$.

${ }^{1} \mathbf{H}$ NMR $\left(500 \mathrm{MHz}, \mathrm{DMSO}-\mathrm{d}_{6}\right) \delta[\mathrm{ppm}]=12.22(\mathrm{bs}, 1 \mathrm{H}, \mathrm{NH}), 8.47(\mathrm{~s}, 1 \mathrm{H}, \mathrm{H}-4), 7.96\left(\mathrm{dd},{ }^{3} \mathrm{~J}=\right.$ $\left.8.0 \mathrm{~Hz},{ }^{4} \mathrm{~J}=1.4 \mathrm{~Hz}, 1 \mathrm{H}, \mathrm{H}-5\right), 7.85-7.79\left(\mathrm{~m}, 2 \mathrm{H}, \mathrm{H}-2^{\prime}\right), 7.66-7.56\left(\mathrm{~m}, 3 \mathrm{H}, \mathrm{H}-7, \mathrm{H}-3^{\prime}\right), 7.36\left(\mathrm{~d}, 3^{3} \mathrm{~J}=8.3 \mathrm{~Hz}, 1 \mathrm{H}, \mathrm{H}-8\right)$, 7.30-7.26 (m, $1 \mathrm{H}, \mathrm{H}-6)$.

${ }^{13} \mathrm{C}$ NMR $\left(126 \mathrm{MHz}\right.$, DMSO- $\left.d_{6}\right) \delta$ [ppm] = 157.9 (C-2), 142.9 (C-1'), 139.2 (C-8a), 136.8 (C-4), 136.7 (C-3), 136.2 (C4'), 132.2 (C-7), 129.4 (C-3'), 129.2 (C-5), 127.4 (C-2'), 122.7 (C-6), 118.4 (C-4a), 115.6 (C-8).

HRMS (+ESI): calc. for $\mathrm{C}_{15} \mathrm{H}_{11} \mathrm{O}_{2} \mathrm{CINS}[\mathrm{M}+\mathrm{H}]^{+}:$304.0194; found: 304.0202 .

IR (ATR) $\tilde{v}\left[\mathrm{~cm}^{-1}\right]=3190(\mathrm{w}, \mathrm{N}-\mathrm{H}), 3061(\mathrm{w}), 2925(\mathrm{w}), 2851(\mathrm{w}), 1645$ (vs, C=O), 1554 (w, C=C), 1472 (m), 1390 (w), $1250(w), 2271(w), 1087(m, C-C l), 1071(m), 1046(m, S=O), 1012(m), 956(w), 819\left(m, s p^{2}\right.$ C-H), $754\left(m, s p^{2}\right.$ $\mathrm{C}-\mathrm{H}), 739\left(\mathrm{~m}, \mathrm{sp}^{2} \mathrm{C}-\mathrm{H}\right)$.

m.p. $=259-262^{\circ} \mathrm{C}$.

Specific rotation: $[a]_{D}^{25}=+46.0\left(c=1.0\right.$, DMSO $-d_{6}, 86 \%$ ee) .

Chiral HPLC: $86 \%$ ee $\left[{ }^{\odot} \mathrm{CHIRALCEL}\right.$ OJ-RH, $20{ }^{\circ} \mathrm{C}, 20 \rightarrow 100 \%$ (30 min) ${ }^{i} \mathrm{PrOH} / \mathrm{n}$-heptane, $1 \mathrm{~mL} / \mathrm{min}, 210 \mathrm{~nm}, \mathrm{t}_{\mathrm{R}}=$ $9.73 \mathrm{~min}$ (minor), $10.4 \mathrm{~min}$ (major)].

\subsection{6. (R)-3-((4-Bromophenyl)sulfinyl)-2-quinolone (8e)}<smiles>O=c1[nH]c2ccccc2cc1S(=O)c1ccc(Br)cc1</smiles>
Following GP3 the entitled sulfoxide $8 \mathbf{e}$ was obtained as an off-white solid $(22.9 \mathrm{mg}$, $65.8 \mu \mathrm{mol}, 66 \%)$.

$\boldsymbol{R}_{\mathrm{f}}\left(30 \% \mathrm{EtOAc} / \mathrm{CH}_{2} \mathrm{Cl}_{2}\right): 0.35$

${ }^{1} \mathrm{H}$ NMR $\left(500 \mathrm{MHz}, \mathrm{DMSO}-d_{6}\right) \delta[\mathrm{ppm}]=12.22(\mathrm{bs}, 1 \mathrm{H}, \mathrm{NH}), 8.47(\mathrm{~s}, 1 \mathrm{H}, \mathrm{H}-4), 7.97-7.94(\mathrm{~m}, 1 \mathrm{H}$, $\mathrm{H}-5), 7.75\left(\mathrm{~m}, 4 \mathrm{H}, \mathrm{H}-2^{\prime}\right.$ and $\left.\mathrm{H}-3^{\prime}\right), 7.63-7.59(\mathrm{~m}, 1 \mathrm{H}, \mathrm{H}-7), 7.36\left(\mathrm{~d},{ }^{3} \mathrm{~J}=8.3 \mathrm{~Hz}, 1 \mathrm{H}, \mathrm{H}-8\right), 7.28\left(\right.$ virt t ${ }^{3} \mathrm{~J}=7.5 \mathrm{~Hz}, 1 \mathrm{H}$, H-6).

${ }^{13} \mathrm{C}$ NMR $\left(126 \mathrm{MHz}\right.$, DMSO- $\left.d_{6}\right) \delta[\mathrm{ppm}]=157.9$ (C-2), 143.4 (C-1'), 139.2 (C-8a), 136.8 (C-3), 136.6 (C-4), 132.3 (C$\left.2^{\prime \dagger}\right), 132.2$ (C-7), 129.2 (C-5), $127.6\left({\mathrm{C}-3^{\prime+}}^{+}\right), 125.1$ (C-4'), 122.8 (C-6), 118.4 (C-4a), 115.6 (C-8)

${ }^{\dagger}$ assignment is interconvertible

HRMS (+ESI): calc. for $\mathrm{C}_{15} \mathrm{H}_{11} \mathrm{O}_{2} \mathrm{BrNS}[\mathrm{M}+\mathrm{H}]^{+}:$347.9688; found: 347.9693 .

IR (ATR) $\tilde{v}\left[\mathrm{~cm}^{-1}\right]=2981(\mathrm{~m}), 2924(\mathrm{~m}), 1648$ (vs, C=O), 1469 (w), 1385 (w), 1261 (w), 1151 (w), 1079 (m, C-Br), $1048(\mathrm{~m}, \mathrm{~S}=\mathrm{O}), 1008(\mathrm{~m}), 947(\mathrm{w}), 814\left(\mathrm{~m}, \mathrm{sp}^{2} \mathrm{C}-\mathrm{H}\right), 753$ (s, sp $\left.\mathrm{sp}^{2} \mathrm{C}-\mathrm{H}\right), 720(\mathrm{w})$.

m.p. $=275-278^{\circ} \mathrm{C}$. 
Specific rotation: $[a]_{D}^{25}=+36.0\left(c=1.0\right.$, DMSO- $\left.d_{6}, 88 \% e e\right)$.

Chiral HPLC: $88 \%$ ee $\left[{ }^{\circ} \mathrm{CHIRALPAK} \mathrm{AD-H}, 20{ }^{\circ} \mathrm{C}, 30 \%{ }^{\mathrm{P}} \mathrm{PrOH} / \mathrm{n}\right.$-heptane, $1 \mathrm{~mL} / \mathrm{min}, 210 \mathrm{~nm}, \mathrm{t}_{\mathrm{R}}=11.1 \mathrm{~min}$ (major), $12.7 \min (\operatorname{minor})]$.

2.5.7. (R)-3-((4-(Trifluoromethyl)phenyl)sulfinyl)-2-quinolone (8f)

$\begin{array}{ll}\mathrm{S}^{\prime}= & \boldsymbol{R}_{\mathrm{f}}\left(30 \% \mathrm{EtOAc} / \mathrm{CH}_{2} \mathrm{Cl}_{2}\right): 0.43 \text {. }\end{array}$

${ }^{1} \mathrm{H}$ NMR $\left(500 \mathrm{MHz}, \mathrm{DMSO}-d_{6}\right) \delta[\mathrm{ppm}]=12.3(\mathrm{bs}, 1 \mathrm{H}, \mathrm{NH}), 8.50(\mathrm{~s}, 1 \mathrm{H}, \mathrm{H}-4), 8.05\left(\right.$ virt d, ${ }^{3} \mathrm{~J} \approx$ $\left.8.2 \mathrm{~Hz}, 2 \mathrm{H}, \mathrm{H}-2^{\prime}\right), 7.96\left(\mathrm{dd},{ }^{3} \mathrm{~J}=7.9,{ }^{4} \mathrm{~J}=1.4 \mathrm{~Hz}, 1 \mathrm{H}, \mathrm{H}-5\right.$ ), 7.91 (virt d, ${ }^{3}$ J $\left.\approx 8.3 \mathrm{~Hz}, 2 \mathrm{H}, \mathrm{H}-3^{\prime}\right), 7.61$ (ddd, ${ }^{3} \mathrm{~J}=8.5$, $7.1 \mathrm{~Hz},{ }^{4} J=1.5 \mathrm{~Hz}, 1 \mathrm{H}, \mathrm{H}-7$ ), $7.37\left(\mathrm{dd},{ }^{3} J=8.2,{ }^{4} J=1.0 \mathrm{~Hz}, 1 \mathrm{H}, \mathrm{H}-8\right), 7.28\left(\mathrm{ddd},{ }^{3} J=8.2,7.2 \mathrm{~Hz},{ }^{4} J=1.1 \mathrm{~Hz}, 1 \mathrm{H}, \mathrm{H}-\right.$ $6)$.

${ }^{13} \mathrm{C}$ NMR $\left(126 \mathrm{MHz}\right.$, DMSO-d $_{6}$ ) $[\mathrm{ppm}]=158.0$ (C-2), 148.8 (C-1'), 139.2 (C-8a), 137.0 (C-4), 136.4 (C-3), 132.3 (C7), $131.4\left(q,{ }^{3} J_{\mathrm{CF}}=31.7 \mathrm{~Hz}, \mathrm{C}-4^{\prime}\right.$ ), $129.3(\mathrm{C}-5), 126.3$ (q, $\left.{ }^{4} J_{\mathrm{CF}}=3.8 \mathrm{~Hz}, \mathrm{C}-3^{\prime}\right), 126.2\left(\mathrm{C}-2^{\prime}\right), 123.7$ (q, ${ }^{2} J_{\mathrm{CF}}=272.7 \mathrm{~Hz}$, $\left.\mathrm{CF}_{3}\right), 122.8(\mathrm{C}-6), 118.4(\mathrm{C}-4 \mathrm{a}), 115.6(\mathrm{C}-8)$.

${ }^{19} \mathrm{~F}$ NMR $\left(376 \mathrm{MHz}, \mathrm{DMSO}-d_{6}\right) \delta[\mathrm{ppm}]=-61.4(\mathrm{~s}, 3 \mathrm{~F})$.

HRMS (+ESI): calc. for $\mathrm{C}_{16} \mathrm{H}_{11} \mathrm{O}_{2} \mathrm{~F}_{3} \mathrm{NS}[\mathrm{M}+\mathrm{H}]^{+}: 338.0457$; found: 338.0464 .

IR (ATR) $\tilde{v}\left[\mathrm{~cm}^{-1}\right]=3194(\mathrm{w}, \mathrm{N}-\mathrm{H}), 2924(\mathrm{w}), 2854$ (w), 1646 (vs, C=O), 1555 (w, C=C), 1467 (w), 1401 (w), 1327 (s,

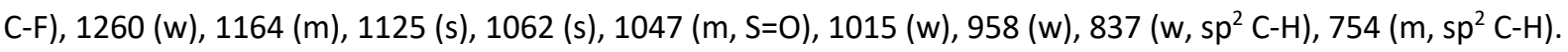
m.p. $=284-287^{\circ} \mathrm{C}$.

Specific rotation: $[a]_{D}^{25}=+56.0\left(\mathrm{c}=1.0\right.$, DMSO- $\left.d_{6}, 86 \% e e\right)$.

Chiral HPLC: $86 \%$ ee $\left[{ }^{\circ} \mathrm{CHIRALPAK}\right.$ AD-H, $20{ }^{\circ} \mathrm{C}, 10 \%{ }^{i} \mathrm{PrOH} / \mathrm{n}$-heptane, $1 \mathrm{~mL} / \mathrm{min}, 210 \mathrm{~nm}, \mathrm{t}_{\mathrm{R}}=19.1 \mathrm{~min}$ (major), $22.9 \min (\operatorname{minor})]$.

2.5.8. (R)-6-Methyl-3-(phenylsulfinyl)-2-quinolone (8g)

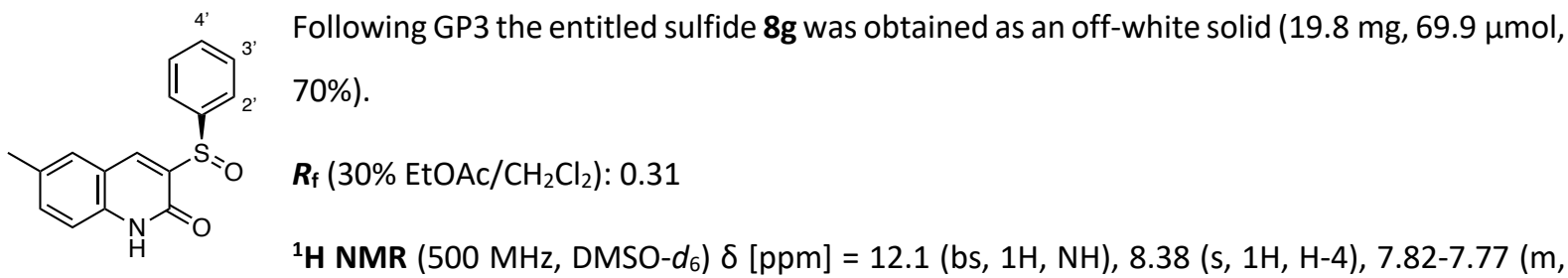
$\left.2 \mathrm{H}, \mathrm{H}-2^{\prime}\right), 7.74-7.71(\mathrm{~m}, 1 \mathrm{H}, \mathrm{H}-5), 7.55-7.50\left(\mathrm{~m}, 3 \mathrm{H}, \mathrm{H}-3^{\prime}\right.$ and $\left.\mathrm{H}-4^{\prime}\right), 7.43\left(\mathrm{dd},{ }^{3} \mathrm{~J}=8.4 \mathrm{~Hz},{ }^{4} \mathrm{~J}=2.0 \mathrm{~Hz}, 1 \mathrm{H}, \mathrm{H}-7\right), 7.26$ $\left(\mathrm{d},{ }^{3} \mathrm{~J}=8.4 \mathrm{~Hz}, 1 \mathrm{H}, \mathrm{H}-8\right), 2.36\left(\mathrm{~s}, 3 \mathrm{H}, \mathrm{CH}_{3}\right)$.

${ }^{13} \mathrm{C}$ NMR (126 MHz, DMSO-d $\left.d_{6}\right) \delta$ [ppm] = 157.9 (C-2), 144.1 (C-1'), 137.2 (C-8a), 137.0 (C-3), 136.2 (C-4), 133.4 (C7), 131.8 (C-6), 131.5 (C-4'), 129.3 (C-3'), 128.5 (C-5), 125.5 (C-2'), 118.4 (C-4a), 115.4 (C-8), $20.4\left(\mathrm{CH}_{3}\right.$ ). 
HRMS (+ESI): calc. for $\mathrm{C}_{16} \mathrm{H}_{14} \mathrm{O}_{2} \mathrm{NS}[\mathrm{M}+\mathrm{H}]^{+}:$284.0740; found: 284.0745 .

IR (ATR) $\tilde{v}\left[\mathrm{~cm}^{-1}\right]=3191(\mathrm{w}, \mathrm{N}-\mathrm{H}), 3053(\mathrm{w}), 2981(\mathrm{w}), 2920\left(\mathrm{w}, \mathrm{sp}^{3} \mathrm{C}-\mathrm{H}\right), 1646(\mathrm{vs}, \mathrm{C}=\mathrm{O}), 1568(\mathrm{w}, \mathrm{C}=\mathrm{C}), 1444(\mathrm{w})$, $1361(w), 1244(w), 1169(w), 1079(m), 1044(s, S=O), 816\left(s, s p^{2} C-H\right), 783\left(m, s p^{2} C-H\right), 748\left(s, s p^{2} C-H\right)$.

m.p. $=304-307^{\circ} \mathrm{C}$.

Specific rotation: $[a]_{D}^{25}=-14.0\left(\mathrm{c}=1.0, \mathrm{DMSO}-d_{6}, 88 \%\right.$ ee) .

Chiral HPLC: $88 \%$ ee $\left[{ }^{\odot} \mathrm{CHIRALPAK} \mathrm{AD-H}, 20{ }^{\circ} \mathrm{C}, 30 \%{ }^{i} \mathrm{PrOH} / n\right.$-heptane, $1 \mathrm{~mL} / \mathrm{min}, 210 \mathrm{~nm}, \mathrm{t}_{\mathrm{R}}=9.66 \mathrm{~min}$ (minor), $11.9 \min$ (major)].

2.5.9. (R)-7-Methyl-3-(phenylsulfinyl)-2-quinolone (8h)<smiles>Cc1ccc2cc(S(=O)(=O)c3ccccc3)c(=O)[nH]c2c1</smiles>

Following GP3 the entitled sulfide $\mathbf{8 h}$ was obtained as an off-white solid $(17.4 \mathrm{mg}$, $61.4 \mu \mathrm{mol}, 61 \%)$.

$\boldsymbol{R}_{\mathbf{f}}\left(30 \% \mathrm{EtOAc} / \mathrm{CH}_{2} \mathrm{Cl}_{2}\right): 0.32$.

${ }^{1} \mathbf{H}$ NMR $(500 \mathrm{MHz}$, DMSO-d $) \delta[\mathrm{ppm}]=12.1(\mathrm{bs}, 1 \mathrm{H}, \mathrm{NH}), 8.42(\mathrm{~s}, 1 \mathrm{H}, \mathrm{H}-4), 7.83\left(\mathrm{~d},{ }^{3} \mathrm{~J}=\right.$ $8.1 \mathrm{~Hz}, 1 \mathrm{H}, \mathrm{H}-5)$, 7.81-7.78 (m, 2H, H-2'), 7.55-7.50 (m, 3H, H-3' and H-4'), $7.14(\mathrm{~s}, 1 \mathrm{H}, \mathrm{H}-8), 7.11\left(\mathrm{dd}, 3^{3} \mathrm{~J}=8.1 \mathrm{~Hz}\right.$, $\left.{ }^{4} J=1.5 \mathrm{~Hz}, 1 \mathrm{H}, \mathrm{H}-6\right), 2.39\left(\mathrm{~s}, 3 \mathrm{H}, \mathrm{CH}_{3}\right)$.

${ }^{13} \mathrm{C}$ NMR $\left(126 \mathrm{MHz}, \mathrm{DMSO}-d_{6}\right) \delta[\mathrm{ppm}]=158.1$ (C-2), 144.2 (C-1'), 142.6 (C-7), 139.3 (C-8a), 136.4 (C-4), 135.7 (C3), 131.5 (C-4'), 129.2 (C-3'), 129.0 (C-5), 125.4 (C-2'), 124.2 (C-6), 116.4 (C-4a), 115.2 (C-8), $21.6\left(\mathrm{CH}_{3}\right)$.

HRMS (+ESI): calc. for $\mathrm{C}_{16} \mathrm{H}_{14} \mathrm{O}_{2} \mathrm{NS}[\mathrm{M}+\mathrm{H}]^{+}:$:284.0740; found: 284.0745 .

IR (ATR) $\tilde{v}\left[\mathrm{~cm}^{-1}\right]=3181(\mathrm{w}, \mathrm{N}-\mathrm{H}), 2981(\mathrm{w}), 2917\left(\mathrm{w}, \mathrm{sp}^{3} \mathrm{C}-\mathrm{H}\right), 1644$ (vs, C=O), $1554(\mathrm{w}, \mathrm{C}=\mathrm{C}), 1442(\mathrm{w}), 1382(\mathrm{w})$, $1255(w), 1207(w), 1143(w), 1079(s), 1053$ (s, S=O), 809 (w, sp $\left.{ }^{2} C-H\right), 747$ (m, sp $\left.{ }^{2} C-H\right), 733\left(m, s p^{2} C-H\right)$.

m.p. $=274-277^{\circ} \mathrm{C}$

Specific rotation: $[a]_{D}^{25}=+96.0\left(\mathrm{c}=1.0, \mathrm{DMSO}-d_{6}, 92 \%\right.$ ee) .

Chiral HPLC: $92 \%$ ee $\left[{ }^{\odot} \mathrm{CHIRALPAK} \mathrm{AD-H}, 20{ }^{\circ} \mathrm{C}, 30 \%{ }^{i} \mathrm{PrOH} / n\right.$-heptane, $1 \mathrm{~mL} / \mathrm{min}, 210 \mathrm{~nm}, \mathrm{t}_{\mathrm{R}}=9.62 \mathrm{~min}$ (major), $12.3 \mathrm{~min}$ (minor)].

\subsubsection{0. (R)-3-((Naphthalen-2-ylsulfinyl)-2-quinolone (8i)}

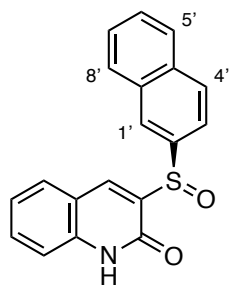

Following GP3 the entitled sulfoxide $8 \mathbf{i}$ was obtained as an off-white solid $(20.7 \mathrm{mg}$, $64.8 \mu \mathrm{mol}, 65 \%)$.

$\boldsymbol{R}_{\mathbf{f}}\left(30 \% \mathrm{EtOAc} / \mathrm{CH}_{2} \mathrm{Cl}_{2}\right): 0.36$.

${ }^{1} \mathrm{H}$ NMR $\left(500 \mathrm{MHz}, \mathrm{DMSO}-\mathrm{d}_{6}\right) \delta[\mathrm{ppm}]=12.2(\mathrm{bs}, 1 \mathrm{H}, \mathrm{NH}), 8.55(\mathrm{~s}, 1 \mathrm{H}, \mathrm{H}-4), 8.46\left(\mathrm{~d},{ }^{4} \mathrm{~J}=1.8 \mathrm{~Hz}\right.$, $\left.1 \mathrm{H}, \mathrm{H}-1^{\prime}\right), 8.14-8.07\left(\mathrm{~m}, 1 \mathrm{H}, \mathrm{H}-8^{\prime}\right), 8.04\left(\mathrm{~d}, 3^{3} \mathrm{~J}=8.7 \mathrm{~Hz}, 1 \mathrm{H}, \mathrm{H}-4^{\prime}\right), 7.97\left(\mathrm{~m}, 2 \mathrm{H}, \mathrm{H}-5, \mathrm{H}-6^{\prime}\right), 7.78\left(\mathrm{dd}, 3^{3} \mathrm{~J}=8.7 \mathrm{~Hz}\right.$, 
$\left.{ }^{4} J=1.8 \mathrm{~Hz}, 1 \mathrm{H}, \mathrm{H}-3^{\prime}\right), 7.63\left(\mathrm{~m}, 2 \mathrm{H}, \mathrm{H}-5^{\prime}, \mathrm{H}-7^{\prime}\right), 7.60\left(\mathrm{ddd},{ }^{3} \mathrm{~J}=8.5,7.2 \mathrm{~Hz},{ }^{4} \mathrm{~J}=1.5 \mathrm{~Hz}, 1 \mathrm{H}, \mathrm{H}-7\right), 7.35\left(\mathrm{~d},{ }^{3} \mathrm{~J}=8.3 \mathrm{~Hz}\right.$, $1 \mathrm{H}, \mathrm{H}-8), 7.32-7.25(\mathrm{~m}, 1 \mathrm{H}, \mathrm{H}-6)$.

${ }^{13} \mathrm{C}$ NMR $\left(126 \mathrm{MHz}\right.$, DMSO- $\left.d_{6}\right) \delta[\mathrm{ppm}]=158.0$ (C-2), $140.9\left(\mathrm{C}-2^{\prime+}\right), 139.2$ (C-8a), 136.9 (C-4), 136.8 (C-3), 134.1 (C-4a'), $132.2\left(\mathrm{C}-8 \mathrm{a}^{\prime \dagger}\right), 132.1$ (C-7), 129.4 (C-4'), 129.2 (C-5), 128.8 (C-8'), 128.2 (C-5'), 128.0 (C-6'), 127.4 (C-7'), $126.8\left(C-1^{\prime}\right), 122.7$ (C-6), 121.1 (C-3'), 118.5 (C-4a), 115.6 (C-8).

${ }^{\dagger}$ assignment is interconvertible

HRMS (+ESI): calc. for $\mathrm{C}_{19} \mathrm{H}_{14} \mathrm{O}_{2} \mathrm{NS}$ [M+H]+: 320.0740; found: 320.0748 .

$\operatorname{IR}\left(\right.$ ATR) $\tilde{v}\left[\mathrm{~cm}^{-1}\right]=2981(\mathrm{~m}), 1650$ (vs, C=0), $1558(\mathrm{w}, \mathrm{C}=\mathrm{C}), 1500(\mathrm{w}), 1469(\mathrm{w}), 1430(\mathrm{w}), 1380(\mathrm{w}), 1253(\mathrm{w})$, $1202(w), 1155(w), 1067(m), 1045(m, S=0), 955(w), 859(w), 814\left(w, s p^{2} C-H\right), 751\left(w, s p^{2} C-H\right)$.

m.p. $=299-302^{\circ} \mathrm{C}$.

Specific rotation: $[a]_{D}^{25}=16.0\left(\mathrm{c}=1.0, \mathrm{DMSO}-d_{6}, 89 \% e e\right)$.

Chiral HPLC: $89 \%$ ee $\left[{ }^{\circ} \mathrm{CHIRALPAK}\right.$ AD-H, $20{ }^{\circ} \mathrm{C}, 30 \%{ }^{\mathrm{P} P \mathrm{POH}} / n$-heptane, $1 \mathrm{~mL} / \mathrm{min}, 210 \mathrm{~nm}, \mathrm{t}_{\mathrm{R}}=13.7 \mathrm{~min}$ (major), $23.1 \mathrm{~min}$ (minor)].

\subsubsection{1. (R)-3-(m-Tolylsulfinyl)-2-quinolone (8j)}<smiles>Cc1cccc(S(=O)c2cc3ccccc3[nH]c2=O)c1</smiles>
Following GP3 the entitled sulfoxide $8 \mathbf{j}$ was obtained as an off-white solid $(22.5 \mathrm{mg}, 80 \mu \mathrm{mol}$, $80 \%)$.

$\boldsymbol{R}_{\mathrm{f}}\left(30 \% \mathrm{EtOAc} / \mathrm{CH}_{2} \mathrm{Cl}_{2}\right): 0.34$.

${ }^{1} \mathrm{H}$ NMR $\left(500 \mathrm{MHz}, \mathrm{DMSO}-\mathrm{d}_{6}\right) \delta[\mathrm{ppm}]=12.2(\mathrm{bs}, 1 \mathrm{H}, \mathrm{NH}), 8.46(\mathrm{~s}, 1 \mathrm{H}, \mathrm{H}-4), 7.95\left(\mathrm{dd},{ }^{3} \mathrm{~J}=\right.$ $\left.7.9 \mathrm{~Hz},{ }^{4} J=1.4 \mathrm{~Hz}, 1 \mathrm{H}, \mathrm{H}-5\right), 7.63-7.56\left(\mathrm{~m}, 3 \mathrm{H}, \mathrm{H}-7, \mathrm{H}-2^{\prime}, \mathrm{H}-6^{\prime}\right), 7.41$ (virt td, $\left.{ }^{3} \mathrm{~J}=7.4 \mathrm{~Hz},{ }^{4} J=1.2 \mathrm{~Hz}, 1 \mathrm{H}, \mathrm{H}-5^{\prime}\right), 7.36$ $\left(d^{3}{ }^{3}=7.9 \mathrm{~Hz}, 1 \mathrm{H}, \mathrm{H}-8\right), 7.33\left(\mathrm{~m}, 1 \mathrm{H}, \mathrm{H}-4^{\prime}\right), 7.28$ (ddd, $\left.{ }^{3} J=8.1,7.2 \mathrm{~Hz},{ }^{4} J=1.1 \mathrm{~Hz}, 1 \mathrm{H}, \mathrm{H}-6\right), 2.34\left(\mathrm{~s}, 3 \mathrm{H}, \mathrm{CH}_{3}\right)$.

${ }^{13} \mathrm{C}$ NMR (126 MHz, DMSO- $d_{6}$ ) $\delta$ [ppm] = 158.0 (C-2), 143.9 (C-1'), 139.2 (C-8a), 138.9 (C-3'), 137.1 (C-3), 136.5 (C-4), 132.2 (C-4'), 132.1 (C-7), 129.2 (C-5), 129.1 (C-5'), 125.5 (C-2'), 122.8 (C-6'), 122.7 (C-6), 118.5 (C-4a), 115.5 (C-8), $21.0\left(\mathrm{CH}_{3}\right)$.

HRMS (+ESI): calc. for $\mathrm{C}_{16} \mathrm{H}_{14} \mathrm{O}_{2} \mathrm{NS}[\mathrm{M}+\mathrm{H}]^{+}$: 284.0740; found: 284.0743 .

IR (ATR) $\tilde{v}\left[\mathrm{~cm}^{-1}\right]=3172(\mathrm{w}, \mathrm{N}-\mathrm{H}), 3051(\mathrm{w}), 2923\left(\mathrm{w}, \mathrm{sp}^{3} \mathrm{C}-\mathrm{H}\right), 2888\left(\mathrm{w}, \mathrm{sp}^{3} \mathrm{C}-\mathrm{H}\right), 2850\left(\mathrm{w}, \mathrm{sp} \mathrm{p}^{3} \mathrm{C}-\mathrm{H}\right), 1647$ (vs, $C=O), 1557(w, C=C), 1475(m), 1430(m), 1252(w), 1079(m), 1048$ (s, S=O), 780 (m, sp $\left.p^{2}-H\right), 755$ (s, sp $\left.p^{2} C-H\right)$, $735\left(\mathrm{~s}, \mathrm{sp} \mathrm{p}^{2} \mathrm{C}-\mathrm{H}\right)$.

m.p. $=272-275^{\circ} \mathrm{C}$.

Specific rotation: $[a]_{D}^{25}=+80.0\left(c=1.0\right.$, DMSO $\left.-d_{6}, 89 \% e e\right)$.

Chiral HPLC: $89 \%$ ee $\left[{ }^{\circ} \mathrm{CHIRALPAK}\right.$ AD-H, $20{ }^{\circ} \mathrm{C}, 30 \%{ }^{\mathrm{P}} \mathrm{PrOH} / \mathrm{n}$-heptane, $1 \mathrm{~mL} / \mathrm{min}, 210 \mathrm{~nm}, \mathrm{t}_{\mathrm{R}}=8.11 \mathrm{~min}$ (major), $10.9 \min ($ minor)]. 
2.5.12. (R)-3-((3-Fluorophenyl)sulfinyl)-2-quinolone (8k)<smiles>O=c1[nH]c2ccccc2cc1S(=O)c1cccc(F)c1</smiles>

Following GP3 the entitled sulfide 8k was obtained as an off-white solid (20.5 mg, $71.4 \mu \mathrm{mol}$, $71 \%)$.

$\boldsymbol{R}_{\mathbf{f}}\left(30 \% \mathrm{EtOAc} / \mathrm{CH}_{2} \mathrm{Cl}_{2}\right): 0.38$.

${ }^{1} \mathbf{H}$ NMR $\left(400 \mathrm{MHz}\right.$, DMSO- $\left.d_{6}\right) \delta[\mathrm{ppm}]=12.3(\mathrm{bs}, 1 \mathrm{H}, \mathrm{NH}), 8.48(\mathrm{~s}, 1 \mathrm{H}, \mathrm{H}-4), 7.95\left(\mathrm{dd},{ }^{3} \mathrm{~J}=\right.$ $\left.7.8 \mathrm{~Hz},{ }^{4} \mathrm{~J}=1.3 \mathrm{~Hz}, 1 \mathrm{H}, \mathrm{H}-5\right), 7.68\left(\mathrm{dt},{ }^{3} \mathrm{~J}=7.8 \mathrm{~Hz},{ }^{4} \mathrm{~J}=1.3 \mathrm{~Hz}, 1 \mathrm{H}, \mathrm{H}-6^{\prime}\right), 7.65-7.54\left(\mathrm{~m}, 3 \mathrm{H}, \mathrm{H}-7, \mathrm{H}-2^{\prime \dagger}, \mathrm{H}^{\prime} 5^{\prime}\right), 7.43-$ $7.33\left(\mathrm{~m}, 2 \mathrm{H}, \mathrm{H}-8, \mathrm{H}-4^{\prime+}\right), 7.28\left(\mathrm{t},{ }^{3} \mathrm{~J}=7.6 \mathrm{~Hz}, 1 \mathrm{H}, \mathrm{H}-6\right)$.

${ }^{13} \mathrm{C}$ NMR $\left(126 \mathrm{MHz}, \mathrm{DMSO}-\mathrm{d}_{6}\right) \delta[\mathrm{ppm}]=162.0\left(\mathrm{~d},{ }^{1} \mathrm{~J}_{\mathrm{CF}}=248.4 \mathrm{~Hz}, \mathrm{C}-3^{\prime}\right), 158.0(\mathrm{C}-2), 146.6\left(\mathrm{~d},{ }^{3} J_{\mathrm{CF}}=5.6 \mathrm{~Hz}, \mathrm{C}-1^{\prime}\right)$, 139.2 (C-8a), 136.9 (C-4), 136.5 (C-3), 132.3 (C-7), 131.5 (d, ${ }^{3} \mathrm{JFF}_{\mathrm{CF}}=7.7 \mathrm{~Hz}, \mathrm{C}-5^{\prime}$ ), 129.3 (C-5), 122.7 (C-6), 121.5 (C$\left.6^{\prime}\right), 118.6\left(d,{ }^{2} J_{C F}=21.5 \mathrm{~Hz}, C-2^{\prime \dagger}\right), 118.4(C-4 a), 115.6(C-8), 112.2\left(d,{ }^{2} J_{C F}=23.9 \mathrm{~Hz}, C-4^{\prime \dagger}\right)$.

${ }^{\dagger}$ assignment is interconvertible

${ }^{19}$ F NMR $\left(376 \mathrm{MHz}, \mathrm{DMSO}-d_{6}\right) \delta[\mathrm{ppm}]=-110.7\left(\mathrm{td},{ }^{3} \mathrm{~J}=8.7 \mathrm{~Hz},{ }^{4} \mathrm{~J}=5.5 \mathrm{~Hz}, 1 \mathrm{~F}\right)$.

HRMS (+ESI): calc. for $\mathrm{C}_{15} \mathrm{H}_{11} \mathrm{O}_{2} \mathrm{FNS}[\mathrm{M}+\mathrm{H}]^{+}:$:288.0489; found: 288.0492 .

IR (ATR) $\tilde{v}\left[\mathrm{~cm}^{-1}\right]=2963(\mathrm{w}), 1645(\mathrm{~m}, \mathrm{C}=0), 1587(\mathrm{w}, \mathrm{C}=\mathrm{C}), 1473(\mathrm{w}), 1423(\mathrm{w}), 1260(\mathrm{~s}, \mathrm{C}-\mathrm{F}), 1214(\mathrm{w}), 1077(\mathrm{~s})$, 1017 (vs, S=O), 864 (w, sp $p^{2}$ C-H), 796 (vs, sp² C-H), 755 (m, sp $p^{2}$ C-H).

m.p. $=316-319^{\circ} \mathrm{C}$.

Specific rotation: $[a]_{D}^{25}=+84.0\left(c=1.0\right.$, DMSO- $d_{6,}, 84 \%$ ee $)$.

Chiral HPLC: $93 \%$ ee $\left[{ }^{\odot} \mathrm{CHIRALPAK}\right.$ AD-H, $5{ }^{\circ} \mathrm{C}, 20 \%{ }^{i} \mathrm{PrOH} / n$-heptane, $1 \mathrm{~mL} / \mathrm{min}, 210 \mathrm{~nm}, \mathrm{t}_{\mathrm{R}}=15.9 \mathrm{~min}$ (major), $18.4 \min (\operatorname{minor})]$.

\subsubsection{3. (R)-3-(o-Tolylsulfinyl)-2-quinolone (8I)}<smiles>Cc1ccccc1S(=O)c1cc2ccccc2[nH]c1=O</smiles>

Following GP3 the entitled sulfoxide 81 was obtained as an off-white solid $(22.9 \mathrm{mg}, 80.8 \mu \mathrm{mol}$, $81 \%)$.

$\boldsymbol{R}_{\mathbf{f}}\left(30 \% \mathrm{EtOAc} / \mathrm{CH}_{2} \mathrm{Cl}_{2}\right): 0.28$.

${ }^{1} \mathrm{H}$ NMR $\left(500 \mathrm{MHz}, \mathrm{DMSO}-d_{6}\right) \delta[\mathrm{ppm}]=12.0(\mathrm{bs}, 1 \mathrm{H}, \mathrm{NH}), 8.52(\mathrm{~s}, 1 \mathrm{H}, \mathrm{H}-4), 7.98\left(\mathrm{dd},{ }^{3} \mathrm{~J}=7.9 \mathrm{~Hz}\right.$, $1.4 \mathrm{~Hz}, 1 \mathrm{H}, \mathrm{H}-5), 7.61\left(\mathrm{ddd},{ }^{3} \mathrm{~J}=8.5,7.1 \mathrm{~Hz},{ }^{4} \mathrm{~J}=1.5 \mathrm{~Hz}, 1 \mathrm{H}, \mathrm{H}-7\right.$ ), 7.50 (dd, $\left.{ }^{3} \mathrm{~J}=8.3 \mathrm{~Hz},{ }^{4} \mathrm{~J}=1.4 \mathrm{~Hz}, 1 \mathrm{H}, \mathrm{H}-6^{\prime}\right), 7.40$ (virt td, $\left.{ }^{3} \mathrm{~J}=7.5 \mathrm{~Hz},{ }^{4} \mathrm{~J}=1.4 \mathrm{~Hz}, 1 \mathrm{H}, \mathrm{H}-5^{\prime}\right), 7.37\left(\mathrm{~d},{ }^{3} \mathrm{~J}=8.3 \mathrm{~Hz}, 1 \mathrm{H}, \mathrm{H}-8\right), 7.32-7.27\left(\mathrm{~m}, 3 \mathrm{H}, \mathrm{H}-6, \mathrm{H}-3^{\prime}, \mathrm{H}^{\prime} 4^{\prime}\right), 2.69$ (s, $\left.3 \mathrm{H}, \mathrm{CH}_{3}\right)$.

${ }^{13} \mathrm{C}$ NMR (126 MHz, DMSO-d 6 ) $\delta$ [ppm] = 157.8 (C-2), 142.6 (C-2'), 139.1 (C-8a), 138.0 (C-1'), 137.3 (2C, C-3, C-4), 132.0 (C-7), 131.5 (C-5'), 130.7 (C-3'), 129.1 (C-5), 127.2 (C-4'), 125.5 (C-6'), 122.7 (C-6), 118.5 (C-4a), 115.5 (C-8), $18.6\left(\mathrm{CH}_{3}\right)$.

HRMS (+ESI): calc. for $\mathrm{C}_{16} \mathrm{H}_{14} \mathrm{O}_{2} \mathrm{NS}[\mathrm{M}+\mathrm{H}]^{+}$: 284.0740; found: 284.0746 . 
IR (ATR) $\tilde{v}\left[\mathrm{~cm}^{-1}\right]=3124(\mathrm{w}, \mathrm{N}-\mathrm{H}), 3048(\mathrm{w}), 3013(\mathrm{w}), 2926\left(\mathrm{w}, \mathrm{sp}^{3} \mathrm{C}-\mathrm{H}\right), 2889\left(\mathrm{w}, \mathrm{sp}^{3} \mathrm{C}-\mathrm{H}\right), 1654$ (vs, C=O), 1557 $(w, C=C), 1468(w), 1430(w), 1256(w), 1201(w), 1063(w), 1036(w, S=0), 753\left(m, s p^{2} C-H\right)$.

m.p. $=285-288^{\circ} \mathrm{C}$.

Specific rotation: $[a]_{D}^{25}=-90.0\left(\mathrm{c}=1.0, \mathrm{DMSO}-d_{6}, 96 \%\right.$ ee $)$.

Chiral HPLC: $96 \%$ ee $\left[{ }^{\odot} \mathrm{CHIRALPAK} \mathrm{AD-H}, 20{ }^{\circ} \mathrm{C}, 30 \%{ }^{i} \mathrm{PrOH} / n\right.$-heptane, $1 \mathrm{~mL} / \mathrm{min}, 210 \mathrm{~nm}, \mathrm{t}_{\mathrm{R}}=10.8 \mathrm{~min}$ (major), $16.2 \min (\operatorname{minor})]$.

\subsubsection{4. (R)-3-((2-Ethylphenyl)sulfinyl)-2-quinolone (8m)}

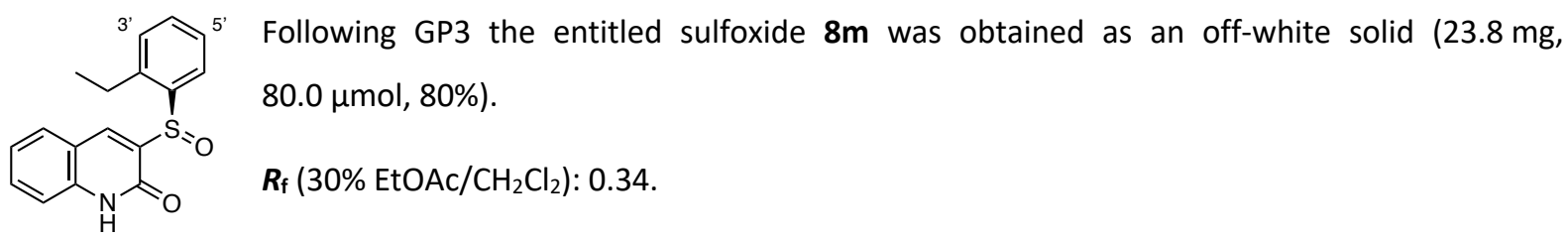
${ }^{1} \mathrm{H}$ NMR $\left(500 \mathrm{MHz}, \mathrm{DMSO}-d_{6}\right) \delta[\mathrm{ppm}]=12.1$ (bs, $\left.1 \mathrm{H}, \mathrm{NH}\right), 8.54(\mathrm{~s}, 1 \mathrm{H}, \mathrm{H}-4), 7.99\left(\mathrm{dd},{ }^{3} \mathrm{~J}=8.0 \mathrm{~Hz},{ }^{4} \mathrm{~J}=1.4 \mathrm{~Hz}, 1 \mathrm{H}\right.$, $\mathrm{H}-5$ ), $7.61\left(\mathrm{ddd},{ }^{3} \mathrm{~J}=8.5,7.2 \mathrm{~Hz},{ }^{4} \mathrm{~J}=1.5 \mathrm{~Hz}, 1 \mathrm{H}, \mathrm{H}-7\right.$ ), 7.47 (d, $\left.{ }^{3} \mathrm{~J}=7.4 \mathrm{~Hz}, 1 \mathrm{H}, \mathrm{H}-6^{\prime}\right), 7.44\left(\mathrm{td},{ }^{3} \mathrm{~J}=7.4 \mathrm{~Hz},{ }^{4} \mathrm{~J}=1.4 \mathrm{~Hz}\right.$, $\left.1 \mathrm{H}, \mathrm{H}-4^{\prime}\right), 7.39-7.34\left(\mathrm{~m}, 2 \mathrm{H}, \mathrm{H}-8, \mathrm{H}-3^{\prime}\right), 7.34-7.26\left(\mathrm{~m}, 2 \mathrm{H}, \mathrm{H}-6, \mathrm{H}-5^{\prime}\right), 3.24\left(\mathrm{dq},{ }^{2} \mathrm{~J}=15.0 \mathrm{~Hz}, 3^{3} \mathrm{~J}=7.5 \mathrm{~Hz}, 1 \mathrm{H}, \mathrm{CH}_{2}\right)$, $2.98\left(\mathrm{dq},{ }^{2} \mathrm{~J}=14.9 \mathrm{~Hz},{ }^{3} \mathrm{~J}=7.5 \mathrm{~Hz}, 1 \mathrm{H}, \mathrm{CH}_{2}\right), 1.32\left(\mathrm{t},{ }^{3} \mathrm{~J}=7.5 \mathrm{~Hz}, 3 \mathrm{H}, \mathrm{CH}_{3}\right)$.

${ }^{13} \mathrm{C}$ NMR (126 MHz, DMSO-d $\left.d_{6}\right) \delta[\mathrm{ppm}]=157.7$ (C-2), 144.0 (C-2'), 142.2 (C-1'), 139.2 (C-8a), 137.5 (C-4), 137.2 (C-3), 132.0 (C-7), 131.7 (C-4'), 129.2 (C-3'), 129.1 (C-5), 127.4 (C-5'), 125.6 (C-6'), 122.7 (C-6), 118.5 (C-4a), 115.5 (C-8), $25.0\left(\mathrm{CH}_{2}\right), 16.0\left(\mathrm{CH}_{3}\right)$.

HRMS (+ESI): calc. for $\mathrm{C}_{17} \mathrm{H}_{16} \mathrm{O}_{2} \mathrm{NS}[\mathrm{M}+\mathrm{H}]^{+}$: 298.0896; found: 298.0901.

IR (ATR) $\tilde{v}\left[\mathrm{~cm}^{-1}\right]=3012(\mathrm{w}), 2964\left(\mathrm{w}, \mathrm{sp}^{3} \mathrm{C}-\mathrm{H}\right), 2878\left(\mathrm{w}, \mathrm{sp}^{3} \mathrm{C}-\mathrm{H}\right), 1653(\mathrm{vs}, \mathrm{C}=\mathrm{O}), 1557(\mathrm{w}, \mathrm{C}=\mathrm{C}), 1468(\mathrm{~m}), 1428$ (w), $1385(w), 1255(w), 1202(w), 1060(m), 1042$ (m, S=O), 790 (w, sp $\left.{ }^{2} C-H\right), 754\left(s, s p^{2} C-H\right), 736\left(m, s p^{2} C-H\right)$.

m.p. $=288-291^{\circ} \mathrm{C}$.

Specific rotation: $[a]_{D}^{25}=-102.0\left(\mathrm{c}=1.0, \mathrm{DMSO}-d_{6}, 92 \%\right.$ ee) .

Chiral HPLC: $92 \%$ ee $\left[{ }^{\circ} \mathrm{CHIRALPAK} \mathrm{AD-H}, 20{ }^{\circ} \mathrm{C}, 50 \%{ }^{i} \mathrm{PrOH} / \mathrm{n}\right.$-heptane, $1 \mathrm{~mL} / \mathrm{min}, 210 \mathrm{~nm}, \mathrm{t}_{\mathrm{R}}=6.97 \mathrm{~min}$ (major), $9.44 \min (\operatorname{minor})]$.

2.5.15. (R)-3-((2-Methoxyphenyl)sulfinyl)-2-quinolone (8n)

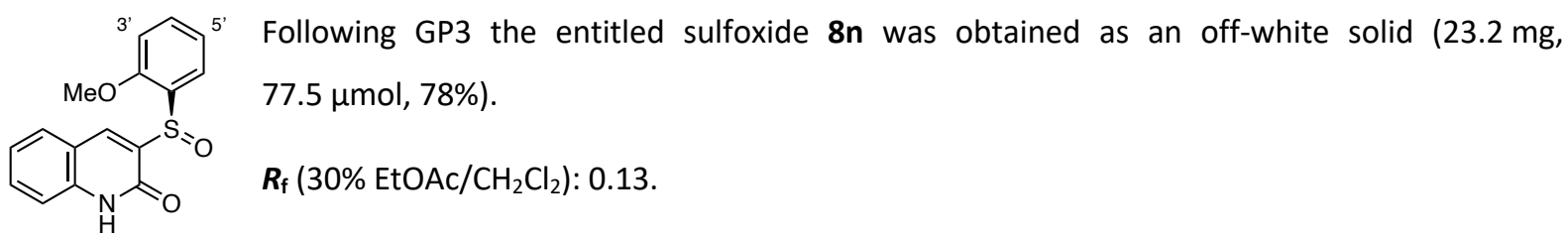
${ }^{1} \mathrm{H}$ NMR $\left(500 \mathrm{MHz}, \mathrm{DMSO}-d_{6}\right) \delta[\mathrm{ppm}]=12.1$ (bs, $\left.1 \mathrm{H}, \mathrm{NH}\right), 8.40(\mathrm{~s}, 1 \mathrm{H}, \mathrm{H}-4), 7.94\left(\mathrm{dd},{ }^{3} \mathrm{~J}=7.9 \mathrm{~Hz},{ }^{4} \mathrm{~J}=1.4 \mathrm{~Hz}, 1 \mathrm{H}\right.$, H-5), 7.62 (ddd, ${ }^{3} J=8.5,7.2 \mathrm{~Hz},{ }^{4} J=1.5 \mathrm{~Hz}, 1 \mathrm{H}, \mathrm{H}-7$ ), $7.52\left(\mathrm{ddd},{ }^{3} \mathrm{~J}=8.7,7.3 \mathrm{~Hz},{ }^{4} J=1.7 \mathrm{~Hz}, 1 \mathrm{H}, \mathrm{H}-4^{\prime}\right), 7.41-7.33$ 
$\left(\mathrm{m}, 2 \mathrm{H}, \mathrm{H}-8, \mathrm{H}-6^{\prime}\right), 7.28\left(\mathrm{ddd},{ }^{3} \mathrm{~J}=8.2,7.3 \mathrm{~Hz},{ }^{4} \mathrm{~J}=1.1 \mathrm{~Hz}, 1 \mathrm{H}, \mathrm{H}-6\right), 7.19\left(\mathrm{dd},{ }^{3} \mathrm{~J}=8.5 \mathrm{~Hz},{ }^{4} \mathrm{~J}=1.1 \mathrm{~Hz}, 1 \mathrm{H}, \mathrm{H}-3^{\prime}\right), 7.04$ $\left(\mathrm{td},{ }^{3} \mathrm{~J}=7.6 \mathrm{~Hz},{ }^{4} \mathrm{~J}=1.0 \mathrm{~Hz}, 1 \mathrm{H}, \mathrm{H}-5^{\prime}\right), 3.89\left(\mathrm{~s}, 3 \mathrm{H}, \mathrm{OCH}_{3}\right)$.

${ }^{13} \mathrm{C}$ NMR $(126 \mathrm{MHz}$, DMSO-d 6 ) $\delta$ [ppm] = 157.9 (C-2), 157.7 (C-2'), 139.4 (C-8a), 139.0 (C-4), 135.7 (C-3), 133.6 (C4'), 132.1 (C-7), 131.1 (C-1'), 129.1 (C-5), 127.0 (C-6'), 122.6 (C-6), 121.4 (C-5'), 118.5 (C-4a), 115.5 (C-8), 112.6 $\left(\mathrm{C}-3^{\prime}\right), 56.3\left(\mathrm{OCH}_{3}\right)$.

HRMS (+ESI): calc. for $\mathrm{C}_{16} \mathrm{H}_{14} \mathrm{O}_{3} \mathrm{NS}[\mathrm{M}+\mathrm{H}]^{+}:$300.0689; found: 300.0693 .

IR (ATR) $\tilde{v}\left[\mathrm{~cm}^{-1}\right]=3154(\mathrm{w}, \mathrm{N}-\mathrm{H}), 2924\left(\mathrm{~m}, \mathrm{sp}^{3} \mathrm{C}-\mathrm{H}\right), 2852\left(\mathrm{w}, \mathrm{O}-\mathrm{CH}_{3}\right), 1654(\mathrm{vs}, \mathrm{C}=\mathrm{O}), 1587(\mathrm{w}, \mathrm{C}=\mathrm{C}), 1479(\mathrm{~s})$, $1433(\mathrm{~m}), 1277$ (s), 1249 (m), 1201 (w), 1022 (s, S=O), 795 (w, sp ${ }^{2}$ C-H), 754 (s, sp $p^{2}$ C-H), 736 (m, sp² C-H).

m.p. $=232-235^{\circ} \mathrm{C}$.

Specific rotation: $[a]_{D}^{25}=-64.0\left(c=1.0, \mathrm{DMSO}-d_{6}, 95 \%\right.$ ee $)$.

Chiral HPLC: $95 \%$ ee $\left[{ }^{\circ} \mathrm{CHIRALPAK} \mathrm{AD-H}, 20{ }^{\circ} \mathrm{C}, 30 \%{ }^{i} \mathrm{PrOH} / n\right.$-heptane, $1 \mathrm{~mL} / \mathrm{min}, 210 \mathrm{~nm}, \mathrm{t}_{\mathrm{R}}=11.0 \mathrm{~min}$ (major), $18.4 \mathrm{~min}$ (minor)].

2.5.16. (R)-3-((2,6-Dimethylphenyl)sulfinyl)-2-quinolone (80)<smiles>Cc1ccccc1CS(=O)c1cc2ccccc2[nH]c1=O</smiles>

Following GP3 the entitled sulfoxide 80 was obtained as an off-white solid (12.5 mg, $42.0 \mu \mathrm{mol}, 42 \%)$.

$\boldsymbol{R}_{\mathbf{f}}\left(30 \% \mathrm{EtOAC} / \mathrm{CH}_{2} \mathrm{Cl}_{2}\right): 0.31$.

${ }^{1} \mathbf{H}$ NMR $\left(500 \mathrm{MHz}, \mathrm{DMSO}-d_{6}\right) \delta[\mathrm{ppm}]=12.1$ (bs, $\left.1 \mathrm{H} . \mathrm{NH}\right), 8.49(\mathrm{~s}, 1 \mathrm{H}, \mathrm{H}-4), 7.98\left(\mathrm{dd},{ }^{3} \mathrm{~J}=\right.$ $\left.7.9 \mathrm{~Hz},{ }^{4} J=1.4 \mathrm{~Hz}, 1 \mathrm{H}, \mathrm{H}-5\right), 7.61\left(\mathrm{ddd},{ }^{3} J=8.5,7.2 \mathrm{~Hz},{ }^{4} J=1.5 \mathrm{~Hz}, 1 \mathrm{H}, \mathrm{H}-7\right), 7.39\left(\mathrm{dd},{ }^{3} J=8.4 \mathrm{~Hz},{ }^{4} J=1.0 \mathrm{~Hz}, 1 \mathrm{H}\right.$, $\mathrm{H}-8), 7.34-7.24\left(\mathrm{~m}, 2 \mathrm{H}, \mathrm{H}-6, \mathrm{H}-4^{\prime}\right), 7.08\left(\mathrm{~d},{ }^{3} \mathrm{~J}=7.6 \mathrm{~Hz}, 2 \mathrm{H}, \mathrm{H}-3^{\prime}\right), 2.53\left(\mathrm{~s}, 6 \mathrm{H}, \mathrm{CH}_{3}\right)$.

${ }^{13} \mathrm{C}$ NMR (126 MHz, DMSO-d $) \delta$ [ppm] = 157.8 (C-2), 139.9 (C-2'), 139.1 (C-8a), 138.9 (C-4), 136.9 (C-1'), 134.2 (C-3), 131.9 (C-7), 131.5 (C-4'), 129.9 (C-3'), 129.0 (C-5), 122.6 (C-6), 118.1 (C-4a), 115.5 (C-8), $18.7\left(\mathrm{CH}_{3}\right)$.

HRMS (+ESI): calc. for $\mathrm{C}_{17} \mathrm{H}_{16} \mathrm{O}_{2} \mathrm{NS}[\mathrm{M}+\mathrm{H}]^{+}$: 298.0896; found: 298.0898 .

IR (ATR) $\tilde{v}\left[\mathrm{~cm}^{-1}\right]=2925$ (s, sp $\mathrm{sp}^{3}$-H), 2852 (m, sp $\left.\mathrm{s}^{3} \mathrm{C}-\mathrm{H}\right), 1649$ (vs, C=O), 1557 (w, C=C), 1462 (m), 1434 (m), 1377 (w), $1255(w), 1200(m), 1059(s, S=O), 889(w), 818\left(w, s p^{2} C-H\right), 753\left(s, s p^{2} C-H\right), 736\left(m, s p^{2} C-H\right)$.

m.p. $=286-289^{\circ} \mathrm{C}$.

Specific rotation: $[a]_{D}^{25}=-126.0\left(c=1.0\right.$, DMSO- $\left.d_{6}, 99 \% e e\right)$.

Chiral HPLC: $99 \%$ ee $\left[{ }^{\circ} \mathrm{CHIRALPAK} \mathrm{AD-H}, 20{ }^{\circ} \mathrm{C}, 30 \%{ }^{i} \mathrm{PrOH} / \mathrm{n}\right.$-heptane, $1 \mathrm{~mL} / \mathrm{min}, 210 \mathrm{~nm}, \mathrm{t}_{\mathrm{R}}=12.0 \mathrm{~min}$ (minor), $13.7 \mathrm{~min}$ (major)]. 
2.5.17. (R)-3-((2,3,5,6-Tetrafluorophenyl)sulfinyl)-2-quinolone (8p)

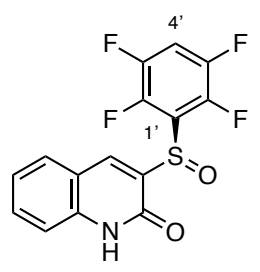

Following GP3 the entitled sulfoxide $\mathbf{8 p}$ was obtained as an off-white solid $(16.9 \mathrm{mg}$, $49.5 \mu \mathrm{mol}, 50 \%)$.

$\boldsymbol{R}_{\mathrm{f}}\left(30 \%\right.$ EtOAc $\left./ \mathrm{CH}_{2} \mathrm{Cl}_{2}\right): 0.47$.

${ }^{1} \mathrm{H}$ NMR $\left(500 \mathrm{MHz}, \mathrm{DMSO}-d_{6}\right) \delta[\mathrm{ppm}]=12.3$ (bs, $\left.1 \mathrm{H}\right), 8.59$ (bs, $\left.1 \mathrm{H}, \mathrm{H}-4\right), 8.16\left(\mathrm{tt},{ }^{2} J_{\mathrm{HF}}=\right.$ $\left.13.1 \mathrm{~Hz},{ }^{3} \mathrm{JHF}_{\mathrm{HF}}=5.2 \mathrm{~Hz}, 1 \mathrm{H}, \mathrm{H}-4^{\prime}\right), 8.04\left(\mathrm{~d},{ }^{3} \mathrm{~J}=7.8 \mathrm{~Hz}, 1 \mathrm{H}, \mathrm{H}-5\right), 7.66\left(\mathrm{t},{ }^{3} \mathrm{~J}=7.5 \mathrm{~Hz}, 1 \mathrm{H}, \mathrm{H}-7\right), 7.42\left(\mathrm{~d},{ }^{3} \mathrm{~J}=8.3 \mathrm{~Hz}, 1 \mathrm{H}\right.$, $\mathrm{H}-8), 7.33\left(\mathrm{t},{ }^{3} \mathrm{~J}=7.5 \mathrm{~Hz}, 1 \mathrm{H}, \mathrm{H}-6\right)$.

${ }^{13} \mathrm{C}$ NMR $\left(126 \mathrm{MHz}, \mathrm{DMSO}-\mathrm{d}_{6}\right) \delta[\mathrm{ppm}]=157.6(\mathrm{C}-2), 145.3\left(\mathrm{~d},{ }^{1} J_{\mathrm{CF}}=247.0 \mathrm{~Hz}, \mathrm{C}-2^{\prime}\right), 144.8\left(\mathrm{~d},{ }^{1} J_{\mathrm{CF}}=241.4 \mathrm{~Hz}, \mathrm{C}-\right.$ 3'), 139.4 (C-8a), 139.2 (C-4), 132.8 (C-3), 132.5 (C-7), 129.3 (C-5), 122.9 (C-6), 122.8 (t, $\left.{ }^{2} J_{\mathrm{CF}}=16.6 \mathrm{~Hz}, \mathrm{C}-1^{\prime}\right) 118.4$ (C-4a), $115.8(\mathrm{C}-8), 110.9\left(\mathrm{t},{ }^{2} \mathrm{~J}_{\mathrm{CF}}=23.2 \mathrm{~Hz}, \mathrm{C}-4^{\prime}\right)$.

${ }^{19} \mathrm{~F}$ NMR $\left(471 \mathrm{MHz}, \mathrm{DMSO}-d_{6}\right) \delta[\mathrm{ppm}]=-137.4(\mathrm{~m}, 2 \mathrm{~F}),-140.2(\mathrm{~m}, 2 \mathrm{~F})$.

HRMS (+ESI): calc. for $\mathrm{C}_{15} \mathrm{H}_{7} \mathrm{O}_{2} \mathrm{~F}_{4} \mathrm{NaNS}[\mathrm{M}+\mathrm{Na}]^{+}:$364.0026; found: 364.0012

IR (ATR) $\tilde{v}\left[\mathrm{~cm}^{-1}\right]=3053(\mathrm{w}), 2921$ (w), 2921 (w), 1636 (s, C=O), 1590 (s, C=C), 1496 (vs), 1433 (m), 1374 (m), 1227 (s, C-F), 1189 (m), 1071 (vs, S=O), 922 (s), 773 (s), 752 (vs, sp² C-H), 736 (s), 706 (s).

m.p. $=253-256^{\circ} \mathrm{C}$

Specific rotation: $[a]_{D}^{25}=-36.0\left(\mathrm{c}=1.0, \mathrm{DMSO}-d_{6}, 97 \%\right.$ ee) .

Chiral HPLC: $97 \%$ ee $\left[{ }^{\circ} \mathrm{CHIRALPAK} \mathrm{IA,} 20^{\circ} \mathrm{C}, 30 \%{ }^{i} \mathrm{PrOH} / n\right.$-heptane, $1 \mathrm{~mL} / \mathrm{min}, 210 \mathrm{~nm}, \mathrm{t}_{\mathrm{R}}=6.57 \mathrm{~min}$ (major), $12.3 \mathrm{~min}$ (minor)].

2.5.18. N-Methyl-3-(phenylsulfinyl)-2-quinolone (11)<smiles>Cn1c(=O)c(S(=O)c2ccccc2)cc2ccccc21</smiles>

Following GP3 the entitled sulfoxide 11 was obtained as a white solid $(21.0 \mathrm{mg}, 74.1 \mu \mathrm{mol}$, $74 \%)$.

$\boldsymbol{R}_{\mathbf{f}}\left(30 \% \mathrm{EtOAc} / \mathrm{CH}_{2} \mathrm{Cl}_{2}\right): 0.56$.

${ }^{1} \mathrm{H}$ NMR $\left(500 \mathrm{MHz}, \mathrm{DMSO}-d_{6}\right) \delta[\mathrm{ppm}]=8.51(\mathrm{~s}, 1 \mathrm{H}, \mathrm{H}-4), 8.04\left(\mathrm{dd},{ }^{3} \mathrm{~J}=7.8 \mathrm{~Hz},{ }^{4} \mathrm{~J}=1.6 \mathrm{~Hz}, 1 \mathrm{H}\right.$, H-5), 7.83-7.79 (m, 2H, H-2'), $7.73\left(\mathrm{ddd}^{3}{ }^{3} \mathrm{~J}=8.7,7.1 \mathrm{~Hz},{ }^{4} \mathrm{~J}=1.6 \mathrm{~Hz}, 1 \mathrm{H}, \mathrm{H}-7\right.$ ), 7.59 (d, $\left.{ }^{3} \mathrm{~J}=8.6 \mathrm{~Hz}, 1 \mathrm{H}, \mathrm{H}-8\right), 7.54-$ $7.49\left(\mathrm{~m}, 3 \mathrm{H}, \mathrm{H}-3^{\prime}\right.$ and $\left.\mathrm{H}-4^{\prime}\right), 7.38\left(\right.$ virt $\left.\mathrm{t},{ }^{3} \mathrm{~J}=7.5 \mathrm{~Hz}, 1 \mathrm{H}, \mathrm{H}-6\right), 3.59\left(\mathrm{~s}, 3 \mathrm{H}, \mathrm{CH}_{3}\right)$

${ }^{13} \mathrm{C}$ NMR (126 MHz, DMSO-d (1) $\delta$ [ppm] = 157.3 (C-2), 144.0 (C-1'), 139.9 (C-8a), 136.5 (C-3), 135.7 (C-4), 132.4 (C7), 131.6 (C-4'), 130.1 (C-5), 129.3 (C-3'), 125.7 (C-2'), 122.9 (C-6), 119.2 (C-4a), 115.2 (C-8), $29.1\left(\mathrm{CH}_{3}\right)$.

HRMS (+ESI): calc. for $\mathrm{C}_{16} \mathrm{H}_{14} \mathrm{O}_{2} \mathrm{NS}[\mathrm{M}+\mathrm{H}]^{+}$: 284.0740; found: 284.0744 .

IR (ATR) $\tilde{v}\left[\mathrm{~cm}^{-1}\right]=3055$ (w), 2942 (w), 1639 (vs, C=O), 1590 (s, C=C), 1561 (m, C=C), 1444 (m), 1418 (w), 1371 (w), $1294(w), 1208(m), 1148(w), 1123(w), 1079(m), 1047$ (s, S=O), $952(w), 752$ (s, sp² C-H), 735 (w, sp² C-H).

m.p. $=203-206^{\circ} \mathrm{C}$. 
Chiral HPLC: $0 \%$ ee $\left[{ }^{\circ} \mathrm{CHIRALPAK} \mathrm{AD-H}, 20{ }^{\circ} \mathrm{C}, 20 \%{ }^{i} \mathrm{PrOH} / \mathrm{n}\right.$-heptane, $\left.1 \mathrm{~mL} / \mathrm{min}, 210 \mathrm{~nm}, \mathrm{t}_{\mathrm{R}}=9.79 \mathrm{~min}, 11.3 \mathrm{~min}\right]$.

2.5.19. 3-(Phenylsulfinyl)-2-coumarin (12)

$\begin{array}{ll}3^{\prime} & \text { Following } \mathrm{GP3} \text { the entitled sulfoxide } 12 \text { was obtained as an off-white solid }(24.5 \mathrm{mg} \text {, } \\ 90.6 \mu \mathrm{mol}, 91 \%) \text {. }\end{array}$ ${ }^{1} \mathrm{H}$ NMR $\left(500 \mathrm{MHz}, \mathrm{DMSO}-d_{6}\right) \delta[\mathrm{ppm}]=8.68(\mathrm{~s}, 1 \mathrm{H}, \mathrm{H}-4), 8.04\left(\mathrm{dd},{ }^{3} \mathrm{~J}=7.8 \mathrm{~Hz},{ }^{4} \mathrm{~J}=1.7 \mathrm{~Hz}, 1 \mathrm{H}\right.$, $\mathrm{H}-5)$, 7.83-7.79 (m, 2H, H-2'), $7.72\left(\mathrm{ddd},{ }^{3} \mathrm{~J}=8.8,7.3 \mathrm{~Hz},{ }^{4} \mathrm{~J}=1.6 \mathrm{~Hz}, 1 \mathrm{H}, \mathrm{H}-7\right), 7.59-7.54\left(\mathrm{~m}, 3 \mathrm{H}, \mathrm{H}-3^{\prime}\right.$ and H-4'), 7.49-7.43 (m, 2H, H-6 and H-8).

${ }^{13} \mathrm{C}$ NMR $\left(126 \mathrm{MHz}\right.$, DMSO- $\left.d_{6}\right) \delta$ [ppm] = 156.4 (C-2), 153.5 (C-8a), 142.8 (C-1'), 140.9 (C-4), 133.7 (C-7), 132.9 (C3), 132.1 (C-4'), 129.8 (C-5), 129.5 (C-3'), 125.9 (C-2'), 125.2 (C-6), 118.4 (C-4a), 116.4 (C-8).

HRMS (+ESI): calc. for $\mathrm{C}_{15} \mathrm{H}_{10} \mathrm{O}_{3} \mathrm{NaS}[\mathrm{M}+\mathrm{Na}]^{+}$: 293.0243; found: 293.0212.

IR (ATR) $\tilde{v}\left[\mathrm{~cm}^{-1}\right]=3061$ (w), 3033 (w), 1719 (vs, C=0), 1605 (s), 1560 (m, C=C), 1445 (m), 1356 (w), 1281 (w), $1160(w), 1127(m), 1078(m), 1052$ (s, S=O), $963(m), 919(w), 762$ (s, sp ${ }^{2}$ C-H), 750 (s, sp² C-H), $731\left(m, s p^{2}\right.$ C-H). m.p. $=187-190^{\circ} \mathrm{C}$

Chiral HPLC: $2 \%$ ee $\left[{ }^{\odot} \mathrm{CHIRALPAK} \mathrm{AD-H}, 20{ }^{\circ} \mathrm{C}, 30 \%{ }^{i} \mathrm{PrOH} / \mathrm{n}\right.$-heptane, $\left.1 \mathrm{~mL} / \mathrm{min}, 210 \mathrm{~nm}, \mathrm{t}_{\mathrm{R}}=12.3 \mathrm{~min}, 13.6 \mathrm{~min}\right]$. 


\subsection{Derivatization of the optically enriched sulfoxide 8a}

2.6.1. O-(4-Nitrobenzoyl)hydroxylammonium trifluoromethanesulfonate (14)
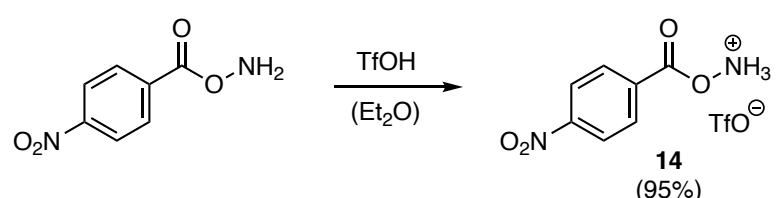

Following a procedure by Wu et al., ${ }^{11} \mathrm{TfOH}(1.73 \mathrm{~mL}, 19.5 \mathrm{mmol}, 1.3$ equiv) was added to a stirring solution of $O$ (4-nitrobenzoyl)hydroxylamine $\left(2.73 \mathrm{~g}, 15.0 \mathrm{mmol}, 1.0\right.$ equiv) in $\mathrm{Et}_{2} \mathrm{O}(30 \mathrm{~mL}, 0.5 \mathrm{M})$ at $0{ }^{\circ} \mathrm{C}$. The external cooling bath was removed, and the reaction mixture was stirred for $5 \mathrm{~h}$ at ambient temperature. The resulting thick white suspension was filtered over a sintered glass funnel and the residual solids were washed with cold $\mathrm{Et}_{2} \mathrm{O}$. Drying under high vacuum afforded the entitled ammonium triflate 14 as an off-white solid (4.75 g, $4.30 \mathrm{mmol}$, 95\%).

${ }^{1} \mathbf{H}$ NMR $\left(400 \mathrm{MHz}\right.$, DMSO- $\left.d_{6}\right) \delta[p p m]=8.32\left(\right.$ virt $\left.\mathrm{d},{ }^{3} \mathrm{~J} \approx 8.8 \mathrm{~Hz}, 2 \mathrm{H}, \mathrm{H}-3\right), 8.17\left(\right.$ virt $\left.\mathrm{d},{ }^{3} \mathrm{~J} \approx 8.8 \mathrm{~Hz}, 2 \mathrm{H}, \mathrm{H}-2\right)$.

${ }^{13} \mathrm{C}$ NMR $\left(126 \mathrm{MHz}, \mathrm{DMSO}-d_{6}\right) \delta[\mathrm{ppm}]=165.9\left(\mathrm{COONH}_{3}\right), 150.1$ (C-4), $136.4(\mathrm{C}-1), 130.8(\mathrm{C}-2), 123.8(\mathrm{C}-3), 120.7$ $\left(q,{ }^{1} J_{C F}=322.3 \mathrm{~Hz}, \mathrm{CF}_{3}\right)$.

${ }^{19} \mathrm{~F}$ NMR $\left(376 \mathrm{MHz}, \mathrm{DMSO}-d_{6}\right) \delta[\mathrm{ppm}]=-77.8(\mathrm{~s}, 3 \mathrm{~F})$.

m.p. $\geq 217-220^{\circ} \mathrm{C}$ (decomposition)

Spectral data matched those reported in the literature. ${ }^{11}$ 

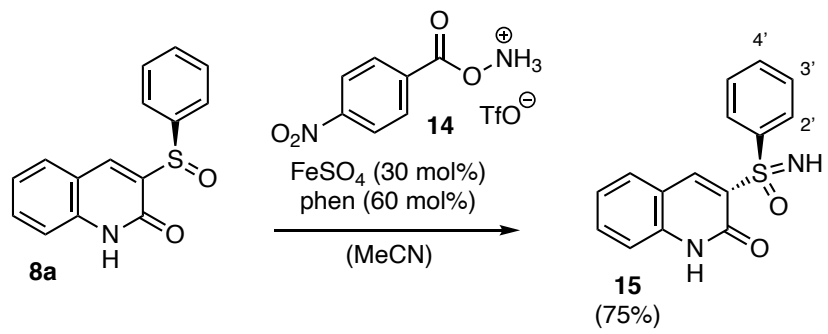

MeCN (710 $\mu \mathrm{L}, 0.2 \mathrm{M}$ ) was added to sulfoxide $8 \mathrm{a}\left(38.3 \mathrm{mg}, 142 \mu \mathrm{mol}, 1.0\right.$ equiv, $86 \%$ ee), $\mathrm{FeSO}_{4} \cdot 5 \mathrm{H}_{2} \mathrm{O}(10.3 \mathrm{mg}$, $42.7 \mu \mathrm{mol}, 0.3$ equiv), phenanthroline ( $15.4 \mathrm{mg}, 85.3 \mu \mathrm{mol}, 0.6$ equiv), and ammonium triflate 14 (142 mg, $427 \mu \mathrm{mo}, 3.0$ equiv) and the resulting white suspension was stirred for $18 \mathrm{~h}$ at $23^{\circ} \mathrm{C}$. The reaction was quenched by addition of sat. aq. $\mathrm{NaHCO}_{3}$ solution $(5 \mathrm{~mL})$ and extracted thrice with $\mathrm{CH}_{2} \mathrm{Cl}_{2}(3 \times 10 \mathrm{~mL})$. The combined organic layers were washed with brine, dried over $\mathrm{Na}_{2} \mathrm{SO}_{4}$ and the solvent was removed in vacuo. The crude material was purified by FCC $\left(20 \% \rightarrow 50 \%\right.$ acetone $\left./ \mathrm{CH}_{2} \mathrm{Cl}_{2}+0.1 \% \mathrm{Et}_{3} \mathrm{~N}\right)$ to yield the entitled $\mathrm{NH}$-sulfoximine 15 as a yellowish solid (30.4 mg, $106 \mu \mathrm{mol}, 75 \%)$.

$\boldsymbol{R}_{\mathrm{f}}\left(30 \%\right.$ acetone $\left./ \mathrm{CH}_{2} \mathrm{Cl}_{2}\right): 0.31$.

${ }^{1} \mathrm{H}$ NMR $\left(500 \mathrm{MHz}, \mathrm{DMSO}-\mathrm{d}_{6}\right) \delta[\mathrm{ppm}]=12.0(\mathrm{bs}, 1 \mathrm{H}, \mathrm{H}-1), 8.85(\mathrm{~s}, 1 \mathrm{H}, \mathrm{H}-4), 8.04-8.00\left(\mathrm{~m}, 2 \mathrm{H}, \mathrm{H}-\mathrm{2}^{\prime}\right), 7.95$ (dd, ${ }^{3}$ J $\left.=7.9 \mathrm{~Hz},{ }^{4} \mathrm{~J}=1.5 \mathrm{~Hz}, 1 \mathrm{H}, \mathrm{H}-5\right), 7.66-7.59\left(\mathrm{~m}, 2 \mathrm{H}, \mathrm{H}-3^{\prime}\right), 7.57-7.52\left(\mathrm{~m}, 2 \mathrm{H}, \mathrm{H}-7\right.$ and $\left.\mathrm{H}-4^{\prime}\right), 7.33\left(\mathrm{dd},{ }^{3} \mathrm{~J}=8.3 \mathrm{~Hz},{ }^{4} \mathrm{~J}=\right.$ $0.9 \mathrm{~Hz}, 1 \mathrm{H}, \mathrm{H}-8), 7.27$ (ddd, $\left.{ }^{3} J=8.1,7.2 \mathrm{~Hz},{ }^{4} J=1.1 \mathrm{~Hz}, 1 \mathrm{H}, \mathrm{H}-6\right), 4.89(\mathrm{~s}, 1 \mathrm{H}, \mathrm{SNH})$.

${ }^{13} \mathrm{C}$ NMR $\left(126 \mathrm{MHz}, \mathrm{DMSO}-d_{6}\right) \delta$ [ppm] = 156.8 (C-2), 142.7 (C-4), 141.6 (C-1'), 140.6 (C-8a), 133.8 (C-3), 133.2 (C7), 132.5 (C-4'), 130.2 (C-5), 128.6 (C-2'), 128.5 (C-3'), 122.6 (C-6), 117.4 (C-4a), 115.2 (C-8).

HRMS (+ESI): calc. for $\mathrm{C}_{15} \mathrm{H}_{13} \mathrm{O}_{2} \mathrm{~N}_{2} \mathrm{~S}[\mathrm{M}+\mathrm{H}]^{+}:$285.0692; found: 285.0692 .

IR (ATR) $\tilde{v}\left[\mathrm{~cm}^{-1}\right]=3241(w), 2924(w), 2853(w), 1655(v s, C=0), 1557(w, C=C), 1447(w), 1224(m), 1141(w)$, $1031(w), 981(w), 959(m), 915(w), 758\left(m, s p^{2} C-H\right), 740\left(w, s p^{2} C-H\right), 683(w)$.

m.p. $=274-277^{\circ} \mathrm{C}$.

Specific rotation: $[a]_{D}^{25}=-48.0\left(\mathrm{c}=1.0, \mathrm{DMSO}-d_{6}, 86 \% e e\right)$.

Chiral HPLC: $86 \%$ ee $\left[{ }^{\circ} \mathrm{CHIRALPAK}\right.$ AS-RH, $20{ }^{\circ} \mathrm{C}, 20 \% \rightarrow 100$ (30 min), ${ }^{i} \mathrm{PrOH} / n$-heptane, $1 \mathrm{~mL} / \mathrm{min}, 210 \mathrm{~nm}, \mathrm{t}_{\mathrm{R}}=$ $8.96 \mathrm{~min}$ (minor), $10.6 \mathrm{~min}$ (major)]. 


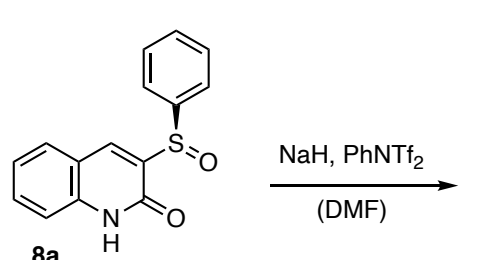

$8 a$

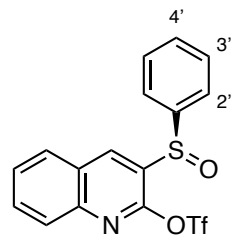

16

$(84 \%)$

Following a procedure by Cacchi et al., ${ }^{12} \mathrm{NaH}$ ( $60 \%$ on mineral oil, $48.2 \mathrm{mg}, 1.20 \mathrm{mmol}, 1.1$ equiv), was added to a stirring suspension of sulfoxide 8 a $(295 \mathrm{mg}, 1.10 \mathrm{mmol}, 1.0$ equiv, $86 \%$ ee) in DMF (3.3 mL). The reaction mixture was stirred for $1 \mathrm{~h}$ at $23{ }^{\circ} \mathrm{C}$ affording an orange solution, whereupon $\mathrm{PhNTf}_{2}(587 \mathrm{mg}, 1.64 \mathrm{mmol}$, 1.5 equiv) was added in one portion and the mixture was stirred for $13 \mathrm{~h}$ at $23^{\circ} \mathrm{C}$. The reaction was quenched by addition of sat. aq. $\mathrm{NH}_{4} \mathrm{Cl}$ solution $(10 \mathrm{~mL})$, diluted with $\mathrm{H}_{2} \mathrm{O}(10 \mathrm{~mL})$ and the aqueous layer was extracted thrice with EtOAc $(3 \times 20 \mathrm{~mL})$. The combined organic layers were washed with brine $(50 \mathrm{~mL})$, dried over $\mathrm{Na}_{2} \mathrm{SO}_{4}$ and the solvent removed under reduced pressure. The crude material was subjected to FCC ( $5 \% \rightarrow 20 \%$ EtOAc/n-hexane) to obtain the entitled triflate 16 as a white crystalline solid (367 mg, $914 \mu \mathrm{mol}, 84 \%$ ).

$\boldsymbol{R}_{\mathrm{f}}(30 \% \mathrm{EtOAc} / n$-hexane): 0.42 .

${ }^{1} \mathbf{H}$ NMR $\left(500 \mathrm{MHz}, \mathrm{CDCl}_{3}\right) \delta[\mathrm{ppm}]=9.01\left(\mathrm{~d},{ }^{4} \mathrm{~J}=0.8 \mathrm{~Hz}, 1 \mathrm{H}, \mathrm{H}-4\right), 8.07\left(\mathrm{dd},{ }^{3} \mathrm{~J}=8.2 \mathrm{~Hz},{ }^{4} \mathrm{~J}=1.4 \mathrm{~Hz}, 1 \mathrm{H}, \mathrm{H}-5\right), 8.03$ $\left(\mathrm{dd},{ }^{3} \mathrm{~J}=8.5 \mathrm{~Hz},{ }^{4} \mathrm{~J}=1.2 \mathrm{~Hz}, 1 \mathrm{H}, \mathrm{H}-8\right), 7.87\left(\mathrm{ddd},{ }^{3} \mathrm{~J}=8.5,7.0 \mathrm{~Hz},{ }^{4} \mathrm{~J}=1.4 \mathrm{~Hz}, 1 \mathrm{H}, \mathrm{H}-7\right), 7.79-7.75\left(\mathrm{~m}, 2 \mathrm{H}, \mathrm{H}-2^{\prime}\right), 7.72$ (ddd, $\left.{ }^{3} J=8.2,7.0 \mathrm{~Hz},{ }^{4} J=1.2 \mathrm{~Hz}, 1 \mathrm{H}, \mathrm{H}-6\right), 7.56-7.45\left(\mathrm{~m}, 3 \mathrm{H}, \mathrm{H}-3^{\prime}, \mathrm{H}-4^{\prime}\right.$ ).

${ }^{13} \mathrm{C}$ NMR $\left(126 \mathrm{MHz}_{\mathrm{C}} \mathrm{CDCl}_{3}\right) \delta[\mathrm{ppm}]=148.6(\mathrm{C}-2), 146.3(\mathrm{C}-8 \mathrm{a}), 142.8\left(\mathrm{C}-1^{\prime}\right), 138.2(\mathrm{C}-4), 132.8\left(\mathrm{C}-7^{\dagger}\right), 132.8(\mathrm{C}-$ $\left.4^{\prime \dagger}\right), 130.8$ (C-3), 129.9 (C-3'), 128.8 (2C, C-6, C-8), 128.6 (C-5), 127.9 (C-4a), $126.2\left(\mathrm{C}-2^{\prime}\right), 118.6\left(\mathrm{~d},{ }^{1} J_{\mathrm{CF}}=321.6 \mathrm{~Hz}\right.$, $\left.\mathrm{CF}_{3}\right)$.

${ }^{\dagger}$ assignment is interconvertible

${ }^{19} \mathrm{~F}$ NMR $\left(376 \mathrm{MHz}, \mathrm{CDCl}_{3}\right) \delta[\mathrm{ppm}]=-72.0(\mathrm{~s}, 3 \mathrm{~F})$.

HRMS (+ESI): calc. for $\mathrm{C}_{16} \mathrm{H}_{11} \mathrm{O}_{4} \mathrm{~F}_{3} \mathrm{NS}_{2}[\mathrm{M}+\mathrm{H}]^{+}:$402.0076; found: 402.0079 .

IR (ATR) $\tilde{v}\left[\mathrm{~cm}^{-1}\right]=3062(\mathrm{w}), 3044(\mathrm{w}), 1589(\mathrm{~m}, \mathrm{C}=\mathrm{C}), 1575(\mathrm{w}, \mathrm{C}=\mathrm{C}), 1499(\mathrm{~m}), 1427$ (vs), 1395 (s), 1342 (m), 1222 (vs, C-F), 1170 (s), 1118 (s), 1057 (s, S=O), 1008 (s), 919 (m), 843 (s), 801 (s), 755 (s, sp² C-H), 734 (s, sp CH). 689 (s).

m.p. $=147-150^{\circ} \mathrm{C}$.

Specific rotation: $[a]_{D}^{25}=-228.0\left(\mathrm{c}=1.0, \mathrm{CDCl}_{3}, 86 \%\right.$ ee $)$.

Chiral HPLC: $86 \%$ ee $\left[{ }^{\odot} \mathrm{CHIRALPAK}\right.$ AS-H, $20{ }^{\circ} \mathrm{C}, 30 \%{ }^{i} \mathrm{PrOH} / \mathrm{n}$-heptane, $1 \mathrm{~mL} / \mathrm{min}, 210 \mathrm{~nm}, \mathrm{t}_{\mathrm{R}}=8.57 \mathrm{~min}$ (major), $12.8 \mathrm{~min}$ (minor)]. 


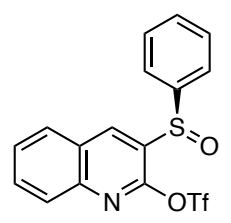

16

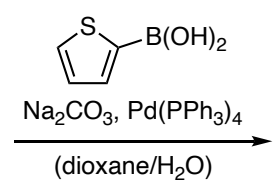

(dioxane/ $\mathrm{H}_{2} \mathrm{O}$ )

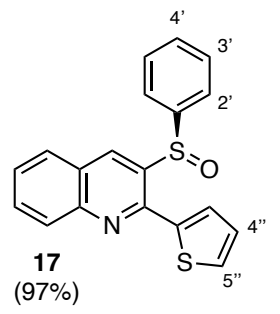

A white suspension of triflate 16 ( $40.1 \mathrm{mg}, 100 \mu \mathrm{mol}, 1.0$ equiv, $86 \%$ ee), 2-thienylboronic acid (16.6 mg, $130 \mu \mathrm{mol}, 1.3$ equiv) and $\mathrm{Na}_{2} \mathrm{CO}_{3}(53.0 \mathrm{mg}, 500 \mu \mathrm{mol}, 5.0$ equiv) in a mixture of 1,4-dioxane (800 $\mu \mathrm{L})$ and $\mathrm{H}_{2} \mathrm{O}$ $(200 \mu \mathrm{L})$ was degassed by consecutive evacuation to vacuum and argon (5 cycles). $\mathrm{Pd}\left(\mathrm{PPh}_{3}\right)_{4}(2.62 \mathrm{mg}, 4.00 \mu \mathrm{mol}$, $4 \mathrm{~mol} \%$ ) was added whereupon the reaction mixture was again degassed by consecutive evacuation to vacuum and argon ( 5 cycles) and the reaction mixture was heated to $110^{\circ} \mathrm{C}$ for $4 \mathrm{~h}$. After cooling to ambient temperature and removal of all volatiles in vacuo the crude material was subjected to FCC ( $20 \% \rightarrow 50 \%$ EtOAc/hexanes) to yield the entitled quinoline 17 as thick yellow oil (32.6 mg, $97.2 \mu \mathrm{mol}, 97 \%$ )

$\boldsymbol{R}_{\mathrm{f}}$ (30\% EtOAc/n-hexane): 0.37 .

${ }^{1} \mathrm{H}$ NMR $\left(500 \mathrm{MHz}, \mathrm{CDCl}_{3}\right) \delta[\mathrm{ppm}]=9.03\left(\mathrm{~d},{ }^{4} J=0.9 \mathrm{~Hz}, 1 \mathrm{H}, \mathrm{H}-4\right), 8.14\left(\mathrm{dd},{ }^{3} J=8.4 \mathrm{~Hz},{ }^{4} J=1.1 \mathrm{~Hz}, 1 \mathrm{H}, \mathrm{H}-8\right), 8.00$ $\left(\mathrm{dd},{ }^{3} J=8.1 \mathrm{~Hz},{ }^{4} \mathrm{~J}=1.4 \mathrm{~Hz}, 1 \mathrm{H}, \mathrm{H}-5\right), 7.80\left(\mathrm{ddd},{ }^{3} J=8.5,6.9 \mathrm{~Hz},{ }^{4} J=1.4 \mathrm{~Hz}, 1 \mathrm{H}, \mathrm{H}-7\right), 7.72\left(\mathrm{dd},{ }^{3} J=3.7 \mathrm{~Hz},{ }^{4} J=1.1 \mathrm{~Hz}\right.$, $\left.1 \mathrm{H}, \mathrm{H}-3^{\prime \prime}\right), 7.63$ (ddd, $\left.{ }^{3} J=8.1,6.9 \mathrm{~Hz},{ }^{4} J=1.2 \mathrm{~Hz}, 1 \mathrm{H}, \mathrm{H}-6\right), 7.51\left(\mathrm{dd},{ }^{3} J=5.1 \mathrm{~Hz},{ }^{4} J=1.1 \mathrm{~Hz}, 1 \mathrm{H}, \mathrm{H}-5^{\prime \prime}\right), 7.37-7.30(\mathrm{~m}$, $\left.1 \mathrm{H}, \mathrm{H}-4^{\prime}\right), 7.27-7.25\left(\mathrm{~m}, 4 \mathrm{H}, \mathrm{H}-2^{\prime}, \mathrm{H}-3^{\prime}\right), 7.18\left(\mathrm{dd},{ }^{3} J=5.1 \mathrm{~Hz},{ }^{4} J=3.7 \mathrm{~Hz}, 1 \mathrm{H}, \mathrm{H}-4^{\prime \prime}\right)$.

${ }^{13} \mathrm{C}$ NMR (126 MHz, CDCl $)_{3}$ ) [ppm] = 149.2 (C-2), 148.2 (C-8a), 144.1 (C-1'), 141.2 (C-2“), 138.3 (C-3), 134.1 (C-4), 131.9 (C-7), 131.6 (C-4'), 129.8 (C-5“), 129.5 (C-3“'), 129.4 (C-2'), 129.2 (C-8), 128.5 (C-5), 127.9 (2C, C-6, C-4“), $127.1(\mathrm{C}-4 \mathrm{a}), 125.8\left(\mathrm{C}-3^{\prime}\right)$.

HRMS (+ESI): calc. for $\mathrm{C}_{19} \mathrm{H}_{14} \mathrm{ONS}_{2}[\mathrm{M}+\mathrm{H}]^{+}: 336.0511$ found: 336.0515.

IR (ATR) $\tilde{v}\left[\mathrm{~cm}^{-1}\right]=3057(\mathrm{w}), 2925(\mathrm{~s}), 2854(\mathrm{~m}), 1615(\mathrm{w}), 1575(\mathrm{~m}, \mathrm{C}=\mathrm{C}), 1548(\mathrm{~m}, \mathrm{C}=\mathrm{C}), 1487(\mathrm{~m}), 1444$ (s), 1426 (s), $1395(\mathrm{~m}), 1371(\mathrm{~m}), 1243$ (w), 1080 (s), 1053 (vs, S=O), $943(\mathrm{~m}), 851$ (m), 750 (s, sp² C-H), 720 (sp² C-H).

Specific rotation: $[a]_{D}^{25}=-24.0\left(\mathrm{c}=1.0, \mathrm{CDCl}_{3}, 86 \% e e\right)$.

Chiral HPLC: $86 \%$ ee $\left[{ }^{\circ} \mathrm{CHIRALPAK}\right.$ AD-H, $20{ }^{\circ} \mathrm{C}, 30 \%{ }^{\mathrm{P}} \mathrm{PrOH} / \mathrm{n}$-heptane, $1 \mathrm{~mL} / \mathrm{min}, 210 \mathrm{~nm}, \mathrm{t}_{\mathrm{R}}=12.1 \mathrm{~min}$ (major), $15.1 \mathrm{~min}$ (minor)]. 
<smiles>CCOc1nc2ccccc2cc1S(=O)c1ccccc1</smiles>

16

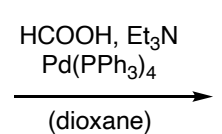

(dioxane)

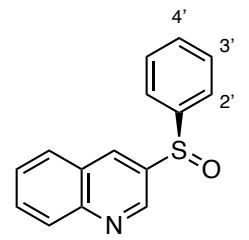

18 $(99 \%)$

$\mathrm{Et}_{3} \mathrm{~N}(27.9 \mu \mathrm{L}, 200 \mu \mathrm{mol}, 4.0$ equiv) was added to a solution of triflate 16 (20.1 mg, $50 \mu \mathrm{mol}, 1.0$ equiv, 86\% ee) in 1,4-dioxane $(1.0 \mathrm{~mL})$ and the solution was degassed by consecutive evacuation to vacuum and argon (5 cycles). $\mathrm{Pd}\left(\mathrm{PPh}_{3}\right)_{4}(2.31 \mathrm{mg}, 2.00 \mu \mathrm{mol}, 4 \mathrm{~mol} \%)$ was added whereupon the reaction mixture was again degassed by consecutive evacuation to vacuum and argon ( 5 cycles). Formic acid ( $4.90 \mu \mathrm{L}, 130 \mu \mathrm{mol}, 2.6$ equiv) was added and the reaction mixture was heated to $110{ }^{\circ} \mathrm{C}$ for $20 \mathrm{~min}$. After cooling to ambient temperature and removal of all volatiles in vacuo, the crude material was subjected to FCC (20\% $\rightarrow 50 \%$ EtOAc/hexanes) to yield the entitled quinoline 18 as thick orange oil (12.6 mg, $49.7 \mu \mathrm{mol}, 99 \%)$

$\boldsymbol{R}_{\mathrm{f}}(20 \%$ EtOAc/hexanes): 0.10.

${ }^{1} \mathrm{H}$ NMR $\left(500 \mathrm{MHz}, \mathrm{CDCl}_{3}\right) \delta[\mathrm{ppm}]=8.88\left(\mathrm{~d},{ }^{4} \mathrm{~J}=2.3 \mathrm{~Hz}, 1 \mathrm{H}, \mathrm{H}-2\right), 8.61\left(\mathrm{dd},{ }^{4} \mathrm{~J}=2.3,0.8 \mathrm{~Hz}, 1 \mathrm{H}, \mathrm{H}-4\right), 8.13\left(\mathrm{dd},{ }^{3} \mathrm{~J}\right.$ $\left.=8.5 \mathrm{~Hz},{ }^{4} \mathrm{~J}=1.1 \mathrm{~Hz}, 1 \mathrm{H}, \mathrm{H}-8\right), 7.94\left(\mathrm{dd},{ }^{3} \mathrm{~J}=8.2 \mathrm{~Hz},{ }^{4} \mathrm{~J}=1.4 \mathrm{~Hz}, 1 \mathrm{H}, \mathrm{H}-5\right), 7.81\left(\mathrm{ddd},{ }^{3} \mathrm{~J}=8.4,6.9 \mathrm{~Hz},{ }^{4} \mathrm{~J}=1.5 \mathrm{~Hz}, 1 \mathrm{H}\right.$, $\mathrm{H}-7), 7.73\left(\mathrm{dd},{ }^{3} \mathrm{~J}=7.7 \mathrm{~Hz},{ }^{4} \mathrm{~J}=1.9 \mathrm{~Hz}, 2 \mathrm{H}, \mathrm{H}-2^{\prime}\right), 7.65\left(\mathrm{ddd},{ }^{3} \mathrm{~J}=8.1,6.9 \mathrm{~Hz},{ }^{4} \mathrm{~J}=1.2 \mathrm{~Hz}, 1 \mathrm{H}, \mathrm{H}-6\right), 7.54-7.45(\mathrm{~m}, 3 \mathrm{H}$, $\left.\mathrm{H}-3^{\prime}, \mathrm{H}-4^{\prime}\right)$.

${ }^{13} \mathrm{C} \mathrm{NMR}\left(126 \mathrm{MHz}, \mathrm{CDCl}_{3}\right) \delta[\mathrm{ppm}]=148.9$ (C-8a), 146.0 (C-2), 144.6 (C-1'), 139.0 (C-3), 133.2 (C-4), 131.9 (C-4'), 131.6 (C-7), 129.9 (C-3'), 129.7 (C-8), 128.6 (C-5), 128.1 (C-6), 127.5 (C-4a), 125.1 (C-2').

HRMS (+ESI): calc. for $\mathrm{C}_{15} \mathrm{H}_{12} \mathrm{ONS}[\mathrm{M}+\mathrm{H}]^{+}:$254.0634; found: 254.0634 .

IR (ATR) $\tilde{v}\left[\mathrm{~cm}^{-1}\right]=3058(w), 2926(w), 1617(w), 1582(w, C=C), 1566(w, C=C), 1495(s), 1444(m), 1358(w), 1086$ (vs), 1048 (vs, S=O), 956 (w), 910 (w), 786 (s, sp² C-H), 750 (vs, sp² C-H), 690 (s).

Specific rotation: $[a]_{D}^{25}=-138.0\left(\mathrm{c}=1.0, \mathrm{CDCl}_{3}, 86 \%\right.$ ee $)$.

Chiral HPLC: $86 \%$ ee $\left[{ }^{\odot} \mathrm{CHIRALPAK}\right.$ AS-H, $20{ }^{\circ} \mathrm{C}, 30 \%{ }^{i} \mathrm{PrOH} / \mathrm{n}$-heptane, $1 \mathrm{~mL} / \mathrm{min}, 210 \mathrm{~nm}, \mathrm{t}_{\mathrm{R}}=15.7 \mathrm{~min}$ (major), $21.2 \min (\operatorname{minor})]$. 
<smiles>O=S(c1ccccc1)c1cc2ccccc2nc1O</smiles>

16

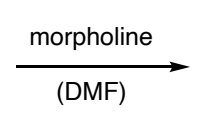

(DMF)

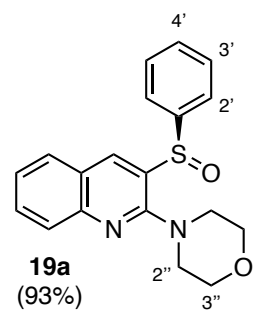

Morpholine (19.0 $\mu \mathrm{L}, 220 \mu \mathrm{mol}, 2.2$ equiv) was added to a suspension of triflate 16 (40.1 mg, $100 \mu \mathrm{mol}, 1.0$ equiv, $88 \%$ ee $)$ in DMF $(250 \mu \mathrm{L})$ affording a yellow solution. The reaction was stirred for $2 \mathrm{~h}$ at $23^{\circ} \mathrm{C}$ before the reaction was quenched by addition of sat. aq. $\mathrm{NH}_{4} \mathrm{Cl}$ solution $(2 \mathrm{~mL})$. The aqueous layer was extracted thrice with EtOAc $(3 \times 5 \mathrm{~mL})$ and the combined organic layers were washed with brine $(20 \mathrm{~mL})$ and dried over $\mathrm{Na}_{2} \mathrm{SO}_{4}$. After removal of all volatiles in vacuo, the crude material was purified by FCC ( $20 \% \rightarrow 50 \%$ EtOAc/ $n$-hexane $)$ to yield the entitled quinoline $19 \mathrm{a}$ as an orange solid (31.5 mg, $93.1 \mu \mathrm{mol}, 93 \%)$.

${ }^{1} \mathrm{H}$ NMR $\left(500 \mathrm{MHz}, \mathrm{CDCl}_{3}\right) \delta 7.96(\mathrm{~d}, J=8.6 \mathrm{~Hz}, 1 \mathrm{H}), 7.90(\mathrm{dd}, J=8.1,1.4 \mathrm{~Hz}, 1 \mathrm{H})$.

$\boldsymbol{R}_{\mathrm{f}}(20 \%$ EtOAc/hexanes $): 0.12$.

${ }^{1} \mathrm{H}$ NMR $\left(500 \mathrm{MHz}, \mathrm{CDCl}_{3}\right) \delta[\mathrm{ppm}]=8.84(\mathrm{~s}, 1 \mathrm{H}, \mathrm{H}-4), 7.96\left(\mathrm{~d},{ }^{3} \mathrm{~J}=8.6 \mathrm{~Hz}, 1 \mathrm{H}, \mathrm{H}-5^{\dagger}\right), 7.90\left(\mathrm{dd},{ }^{3} \mathrm{~J}=8.1 \mathrm{~Hz},{ }^{4} \mathrm{~J}=1.4\right.$ $\mathrm{Hz}, 1 \mathrm{H}, \mathrm{H}-8^{\dagger}$ ), $7.70\left(\mathrm{ddd},{ }^{3} \mathrm{~J}=8.4,6.9 \mathrm{~Hz},{ }^{4} \mathrm{~J}=1.5 \mathrm{~Hz}, 1 \mathrm{H}, \mathrm{H}-7\right), 7.67\left(\mathrm{td},{ }^{3} \mathrm{~J}=8.0 \mathrm{~Hz},{ }^{4} \mathrm{~J}=1.7 \mathrm{~Hz}, 2 \mathrm{H}, \mathrm{H}-2^{\prime}\right), 7.49$ (ddd, $\left.{ }^{3} \mathrm{~J}=8.2,6.9 \mathrm{~Hz},{ }^{4} \mathrm{~J}=1.2 \mathrm{~Hz}, 1 \mathrm{H}, \mathrm{H}-6\right), 7.44-7.36\left(\mathrm{~m}, 3 \mathrm{H}, \mathrm{H}-3^{\prime}, \mathrm{H}-4^{\prime}\right.$ ), 3.87 (ddd, ${ }^{2} \mathrm{~J}=11.3 \mathrm{~Hz},{ }^{3} \mathrm{~J}=6.5 \mathrm{~Hz},{ }^{4} \mathrm{~J}=2.9 \mathrm{~Hz}$, $2 \mathrm{H}, \mathrm{H}-3^{\prime \prime}$ ), 3.73 (ddd, ${ }^{2} \mathrm{~J}=11.3 \mathrm{~Hz},{ }^{3} \mathrm{~J}=6.7 \mathrm{~Hz},{ }^{4} \mathrm{~J}=2.7 \mathrm{~Hz}, 2 \mathrm{H}, \mathrm{H}-3^{\prime \prime}$ ), 3.62 (ddd, ${ }^{2} \mathrm{~J}=11.7 \mathrm{~Hz},{ }^{3} \mathrm{~J}=6.8 \mathrm{~Hz},{ }^{4} \mathrm{~J}=2.8 \mathrm{~Hz}$, $2 \mathrm{H}, \mathrm{m} \mathrm{H}-2^{\prime \prime}$ ), 3.07 (ddd, ${ }^{2} \mathrm{~J}=12.9 \mathrm{~Hz},{ }^{3} \mathrm{~J}=6.6 \mathrm{~Hz},{ }^{4} \mathrm{~J}=2.6 \mathrm{~Hz}, 2 \mathrm{H}, \mathrm{H}-2^{\prime \prime}$ ).

${ }^{13} \mathrm{C}$ NMR $\left(126 \mathrm{MHz}, \mathrm{CDCl}_{3}\right) \delta$ [ppm] = 157.0 (C-2), 148.1 (C-8a), 144.7 (C-1'), 135.5 (C-4), 133.7 (C-3), 131.8 (C-4'), 131.4 (C-7), 129.3 (C-3'), 128.4 (C-5), 127.9 (C-8), 126.0 (C-2'), 125.9 (C-6), 125.8 (C-4a), 66.7 (C-2“'), 50.9 (C-3“).

${ }^{\dagger}$ assignment is interconvertible

HRMS (+ESI): calc. for $\mathrm{C}_{19} \mathrm{H}_{19} \mathrm{O}_{2} \mathrm{~N}_{2} \mathrm{~S}[\mathrm{M}+\mathrm{H}]^{+}$: 339.1162; found: 339.1168.

IR (ATR) $\tilde{v}\left[\mathrm{~cm}^{-1}\right]=3057(\mathrm{w}), 2960\left(\mathrm{~m}, \mathrm{sp}^{3} \mathrm{C}-\mathrm{H}\right), 2918\left(\mathrm{~m}, \mathrm{sp}^{3} \mathrm{C}-\mathrm{H}\right), 2853\left(\mathrm{~m}, \mathrm{sp}^{3} \mathrm{C}-\mathrm{H}\right), 1615(\mathrm{~m}), 1584(\mathrm{~s}, \mathrm{C}=\mathrm{C})$, 1555 (s, C=C), 1493 (w), 1449 (s), 1408 (vs), 1366 (s), 1308 (w), 1259 (m), 1232 (vs, C-N), 1116 (vs, C-O-C), 1081 (s), 1050 (vs, S=O), 1000 (s), $941(\mathrm{~m}), 878(\mathrm{~m}), 784\left(\mathrm{w}, \mathrm{sp}^{2} \mathrm{C}-\mathrm{H}\right), 753\left(\mathrm{~s}, \mathrm{sp} \mathrm{p}^{2} \mathrm{C}-\mathrm{H}\right), 736\left(\mathrm{~m}, \mathrm{sp} \mathrm{p}^{2} \mathrm{C}-\mathrm{H}\right), 689$ (m, sp $\mathrm{p}^{2} \mathrm{C}$ H).

m.p. $=166-169^{\circ} \mathrm{C}$.

Specific rotation: $[a]_{D}^{25}=-58.0\left(\mathrm{c}=1.0, \mathrm{CDCl}_{3}, 89 \%\right.$ ee $)$.

Chiral HPLC: $89 \%$ ee $\left[{ }^{\odot} \mathrm{CHIRALPAK}\right.$ AS- $\mathrm{H}, 20{ }^{\circ} \mathrm{C}, 30 \%{ }^{i} \mathrm{PrOH} / \mathrm{n}$-heptane, $1 \mathrm{~mL} / \mathrm{min}, 210 \mathrm{~nm}, \mathrm{t}_{\mathrm{R}}=11.4 \mathrm{~min}$ (major), $12.7 \mathrm{~min}$ (minor)]. 


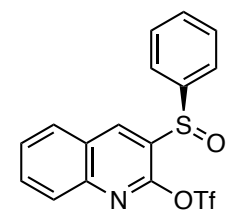

16

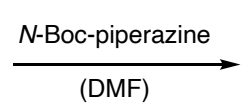

(DMF)<smiles>CC(C)(C)OC(=O)N1CCN(c2nc3ccccc3cc2S(=O)c2ccccc2)CC1</smiles>

$N$-Boc piperazine $(41.0 \mathrm{mg}, 220 \mu \mathrm{mol}, 2.2$ equiv) was added to a suspension of triflate 16 (40.1 mg, $100 \mu \mathrm{mol}$, 1.0 equiv, $86 \%$ ee) in DMF $(250 \mu \mathrm{L})$ affording a yellow solution. The reaction was stirred for $5 \mathrm{~h}$ at $23^{\circ} \mathrm{C}$ before the reaction was quenched by addition of sat. aq. $\mathrm{NH}_{4} \mathrm{Cl}$ solution $(2 \mathrm{~mL})$. The aqueous layer was extracted thrice with EtOAc $(3 \times 5 \mathrm{~mL})$ and the combined organic layers were washed with brine $(20 \mathrm{~mL})$ and dried over $\mathrm{Na}_{2} \mathrm{SO}_{4}$. After removal of all volatiles in vacuo the crude material was purified by FCC ( $20 \% \rightarrow 50 \%$ EtOAc/n-hexane) to yield the entitled quinoline $19 \mathrm{~b}$ as a colorless oil $(40.8 \mathrm{mg}, 93.2 \mathrm{mmol}, 93 \%)$.

$\boldsymbol{R}_{\mathrm{f}}$ (20\% EtOAc/hexanes): 0.13.

${ }^{1} \mathrm{H}$ NMR $\left(500 \mathrm{MHz}, \mathrm{CDCl}_{3}\right) \delta[\mathrm{ppm}]=8.88(\mathrm{~s}, 1 \mathrm{H}, \mathrm{H}-4), 8.03(\mathrm{br} \mathrm{m}, 1 \mathrm{H}, \mathrm{H}-8), 7.94-7.89(\mathrm{~m}, 1 \mathrm{H}, \mathrm{H}-5), 7.73\left(\mathrm{ddd},{ }^{3} \mathrm{~J}=\right.$ 8.5, 7.1 Hz, ${ }^{4} J=1.5 \mathrm{~Hz}, 1 \mathrm{H}, \mathrm{H}-7$ ), 7.64 (dd, $\left.{ }^{3} \mathrm{~J}=6.8 \mathrm{~Hz},{ }^{4} \mathrm{~J}=1.5 \mathrm{~Hz}, 2 \mathrm{H}, \mathrm{H}-2^{\prime}\right), 7.51$ (ddd, ${ }^{3} \mathrm{~J}=8.1,7.0 \mathrm{~Hz},{ }^{4} \mathrm{~J}=1.2 \mathrm{~Hz}$, $1 \mathrm{H}, \mathrm{H}-6), 7.46-7.36\left(\mathrm{~m}, 3 \mathrm{H}, \mathrm{H}-3^{\prime}, \mathrm{H}-4^{\prime}\right), 3.69-3.62\left(\mathrm{~m}, 2 \mathrm{H}, \mathrm{H}-2^{\prime \prime+}\right), 3.58\left(\mathrm{~d},{ }^{2} \mathrm{~J}=11.9 \mathrm{~Hz}, 2 \mathrm{H}, \mathrm{H}-3^{\prime \prime+}{ }^{+}\right), 3.45\left(\mathrm{ddd},{ }^{2} \mathrm{~J}=\right.$ $\left.12.9 \mathrm{~Hz},{ }^{3} \mathrm{~J}=7.1,3.1 \mathrm{~Hz}, 2 \mathrm{H}, \mathrm{H}-2^{\prime \prime \dagger}\right), 3.08\left(\mathrm{~s}, 2 \mathrm{H}, \mathrm{H}-3^{\prime \prime}{ }^{\dagger}\right), 1.49\left(\mathrm{~s}, 9 \mathrm{H}, \mathrm{H}-8^{\prime \prime}\right)$.

${ }^{13} \mathrm{C} \mathrm{NMR}\left(126 \mathrm{MHz}, \mathrm{CDCl}_{3}\right) \delta$ [ppm] = 156.9 (C-2), 154.9 (C-5“), 147.7 (C-8a), 144.6 (C-1'), 135.8 (C-4), 133.9 (C-3), 131.9 (C-4'), 131.6 (C-7), 129.3 (C-3'), 128.4 (C-5), 127.6 (C-8), 126.1 (2C, C-6, C-2'), 125.7 (C-4a), 80.2 (C-7') , 50.5 $\left(\mathrm{C}-2^{\prime \prime+}\right), 28.5\left(\mathrm{C}-8^{\prime \prime}\right)$.

${ }^{\dagger}$ assignment is interconvertible

HRMS (+ESI): calc. for $\mathrm{C}_{24} \mathrm{H}_{28} \mathrm{O}_{3} \mathrm{~N}_{3} \mathrm{~S}[\mathrm{M}+\mathrm{H}]^{+}: 438.1846$ found: 438.1850 .

IR (ATR) $\tilde{v}\left[\mathrm{~cm}^{-1}\right]=2978(\mathrm{w}), 2929\left(\mathrm{w}, \mathrm{sp}^{3} \mathrm{C}-\mathrm{H}\right), 1694$ (vs, C=O), $1582(\mathrm{w}, \mathrm{C}=\mathrm{C}), 1555$ (w, C=C), 1408 (vs), 1366 (m, $\left.\mathrm{C}\left(\mathrm{CH}_{3}\right)_{3}\right), 1232$ (s, C-N), $1169(\mathrm{~s}), 1125(\mathrm{~m}), 1081(\mathrm{~m}), 1050$ (m, S=O), $997(\mathrm{~s}), 873(\mathrm{w}), 754$ (m, sp² C-H), $688(\mathrm{w})$.

Specific rotation: $[a]_{D}^{25}=+30.0\left(c=1.0, \mathrm{CDCl}_{3}, 85 \%\right.$ ee $)$.

Chiral HPLC: $85 \%$ ee $\left[{ }^{\odot} \mathrm{CHIRALPAK} A D-\mathrm{H}, 20{ }^{\circ} \mathrm{C}, 30 \%{ }^{i} \mathrm{PrOH} / \mathrm{n}\right.$-heptane, $1 \mathrm{~mL} / \mathrm{min}, 210 \mathrm{~nm}, \mathrm{t}_{\mathrm{R}}=10.2 \mathrm{~min}$ (major), $12.0 \mathrm{~min}$ (minor)]. 


\section{Analytical data}

\section{1. ${ }^{1} \mathrm{H}$ and ${ }^{13} \mathrm{C}$ spectra of new compounds}

3.1.1. 3-Phenylthio-2-quinolone (7a)

${ }^{1} \mathrm{H}$ NMR $\left(500 \mathrm{MHz}\right.$, DMSO- $\left.d_{6}\right)$

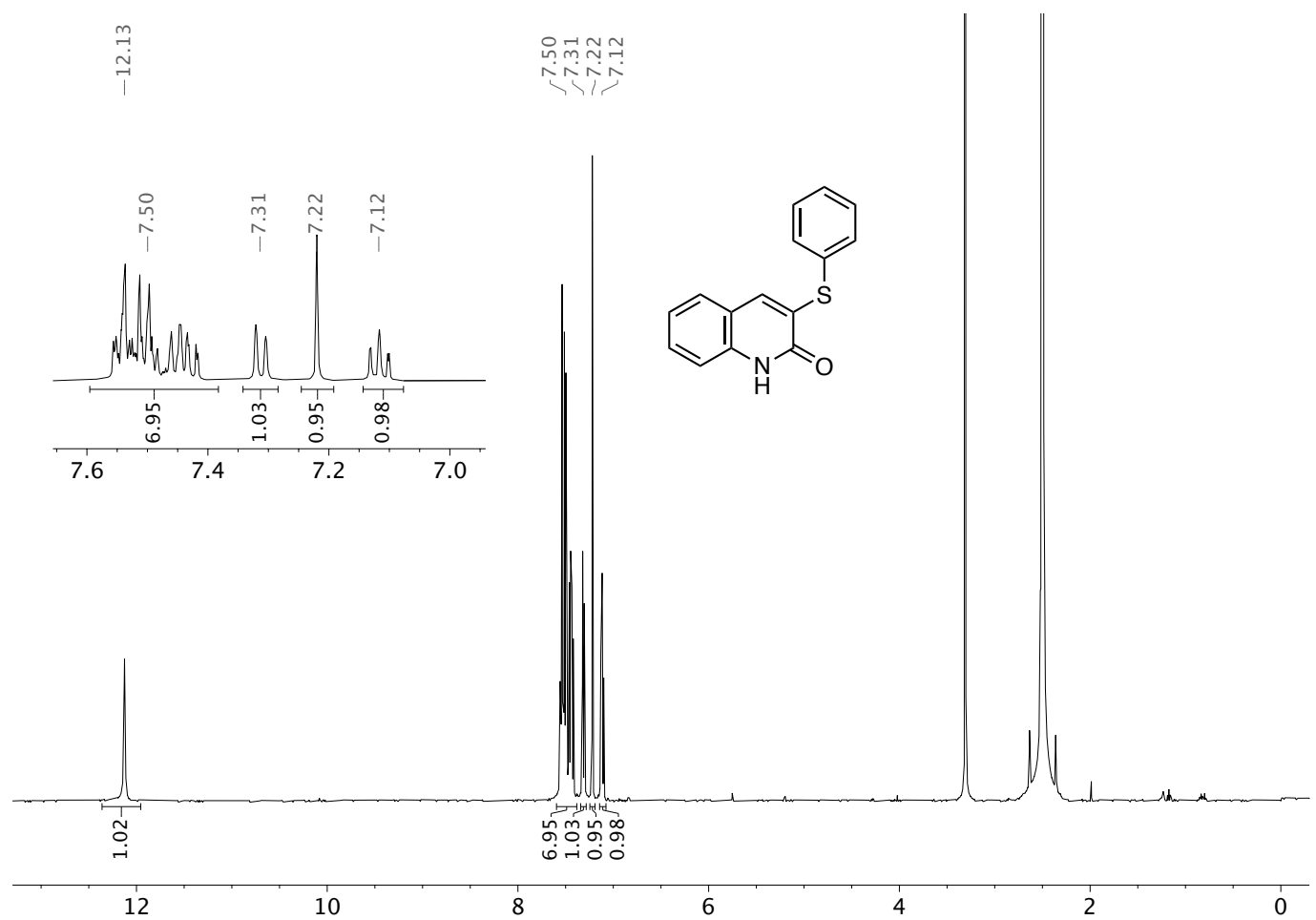

${ }^{13} \mathrm{C}$ NMR $(126 \mathrm{MHz}$, DMSO-d6)
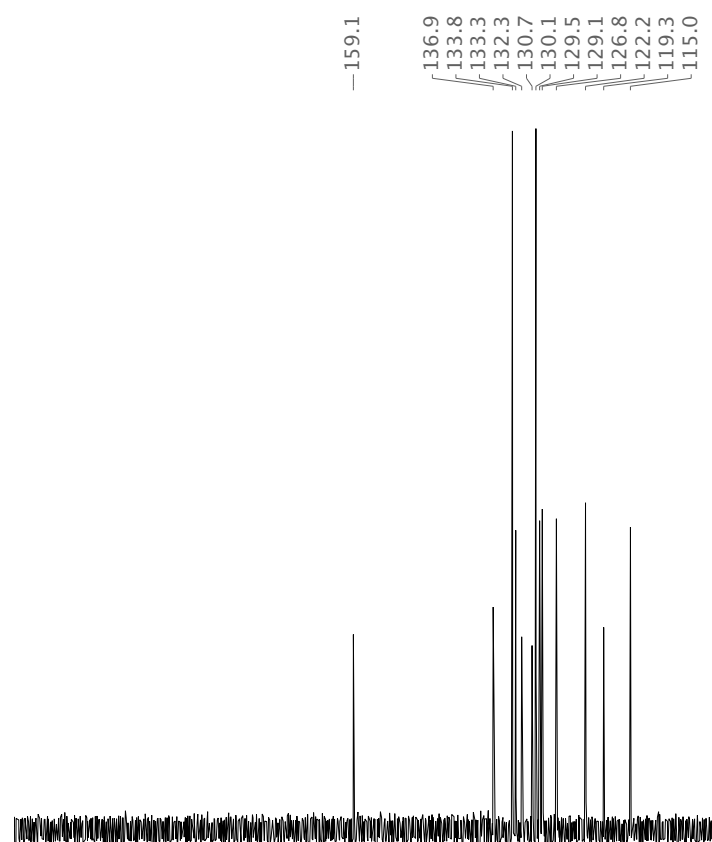

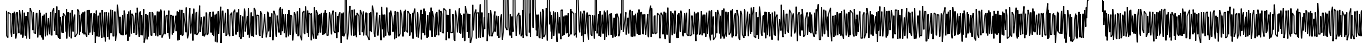

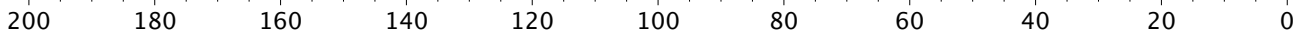


3.1.2. 3-(p-Tolylthio)-2-quinolone (7b)

${ }^{1} \mathrm{H}$ NMR (500 MHz, DMSO- $d_{6}$ )

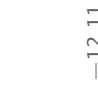

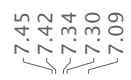
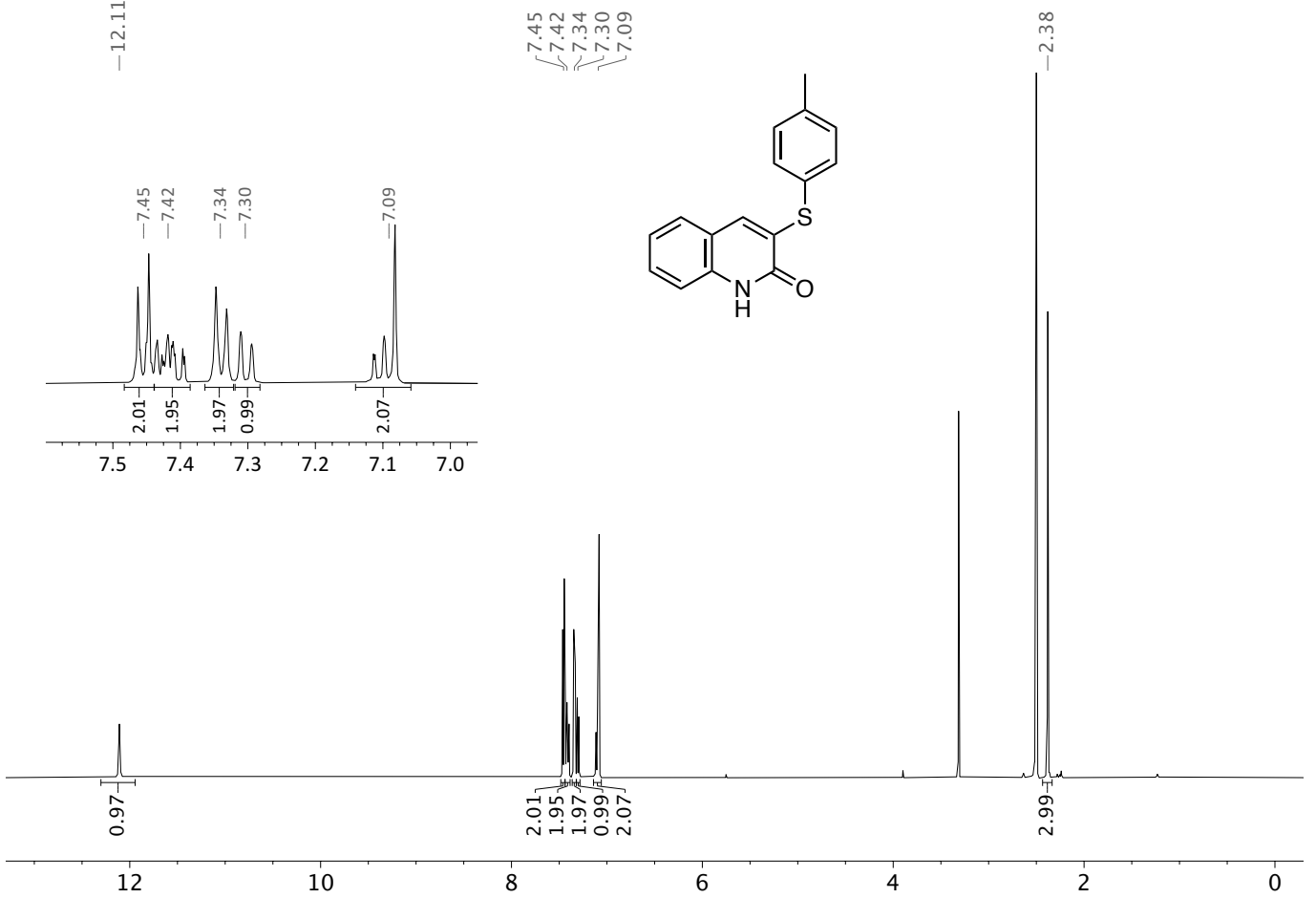

${ }^{13} \mathrm{C}$ NMR (126 MHz, DMSO- $d_{6}$ )

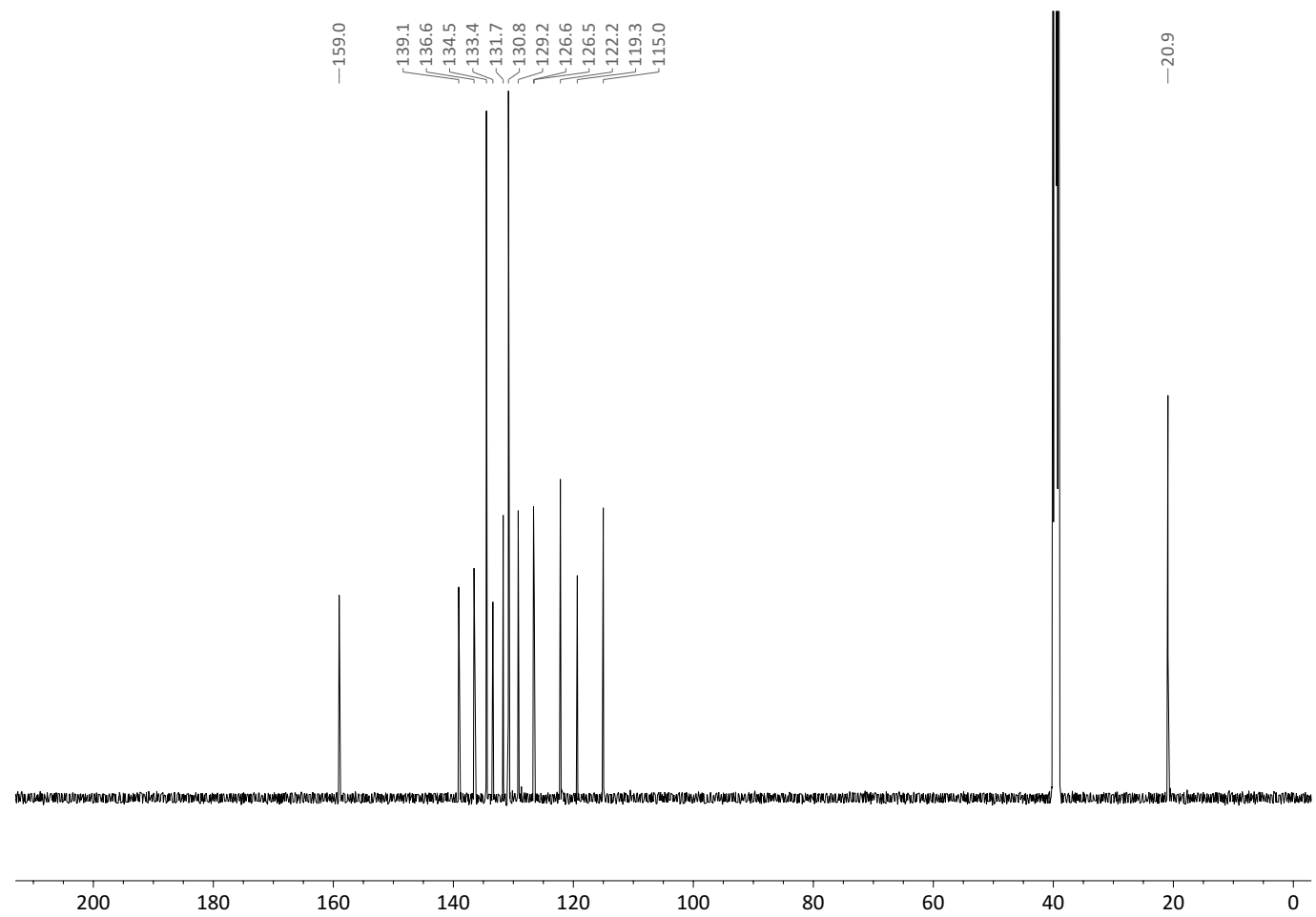


3.1.3. 3-((4-Fluorophenyl)thio)-2-quinolone (7c)

${ }^{1} \mathrm{H}$ NMR (500 MHz, DMSO- $\left.d_{6}\right)$

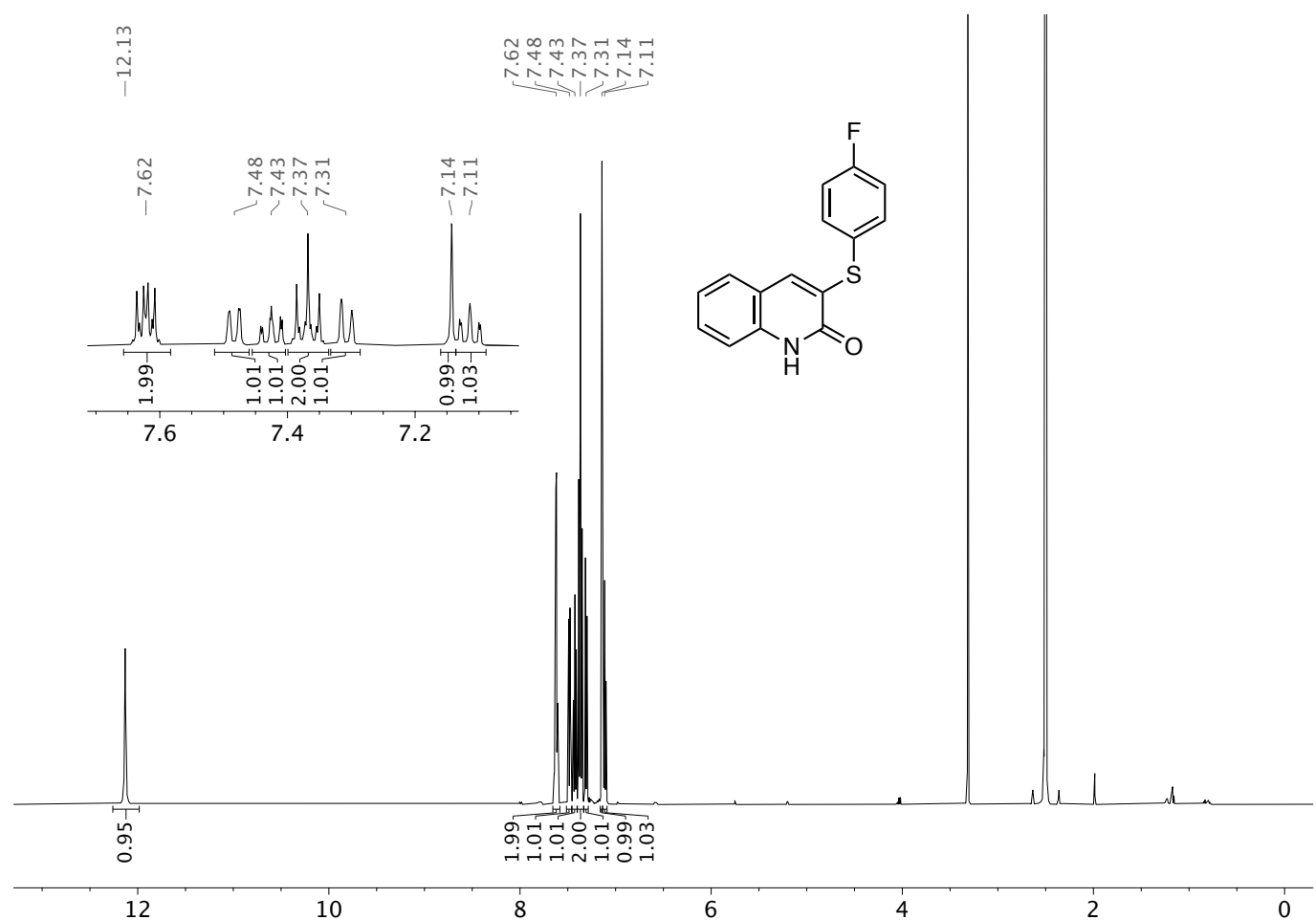

${ }^{13} \mathrm{C}$ NMR (126 MHz, DMSO- $\left.d_{6}\right)$
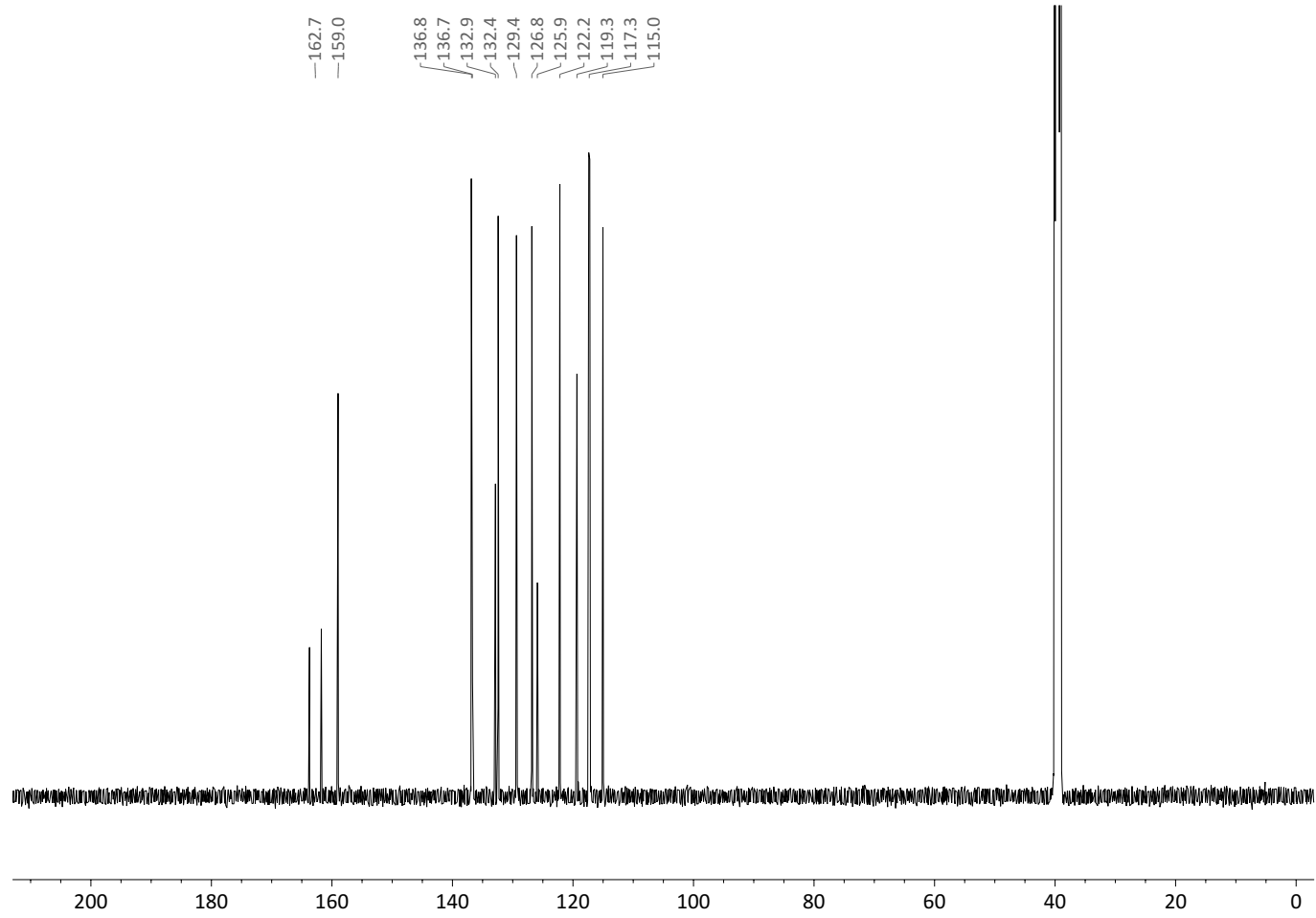
${ }^{19}$ F NMR (376 MHz, DMSO- $d_{6}$ )

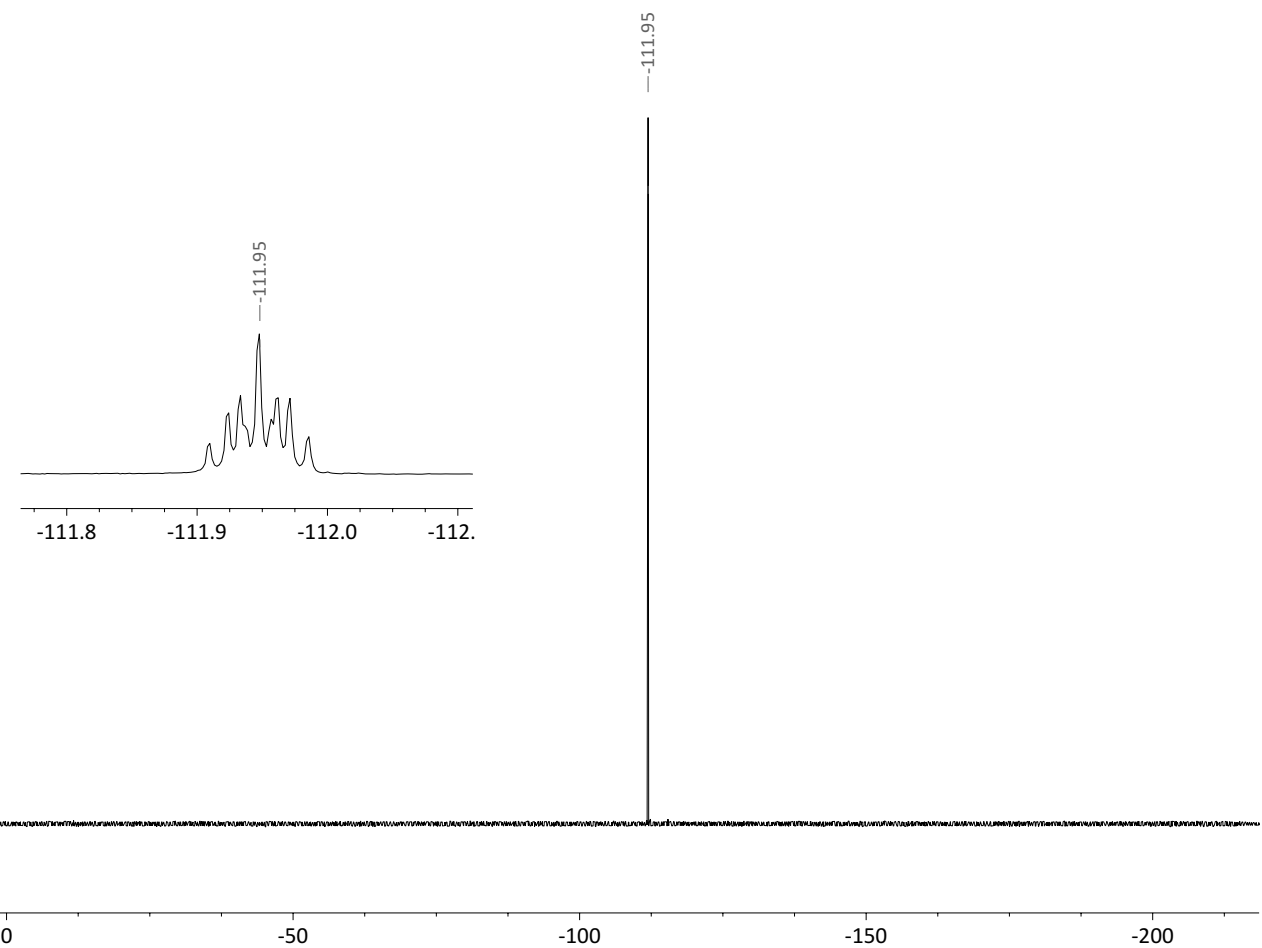


3.1.4. 3-((4-Chlorophenyl)thio-2-quinolone (7d)

${ }^{1} \mathrm{H}$ NMR (500 MHz, DMSO- $\left.d_{6}\right)$

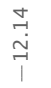

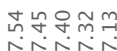
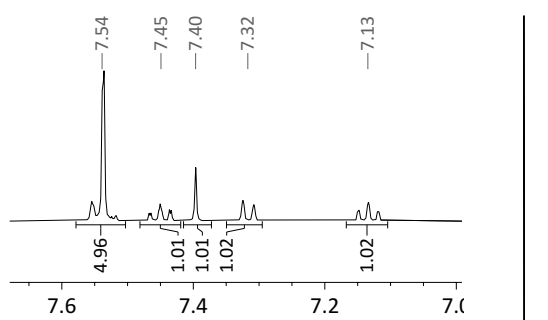<smiles>O=c1[nH]c2ccccc2cc1Sc1ccc(Cl)cc1</smiles>

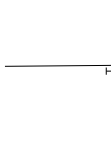

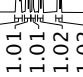

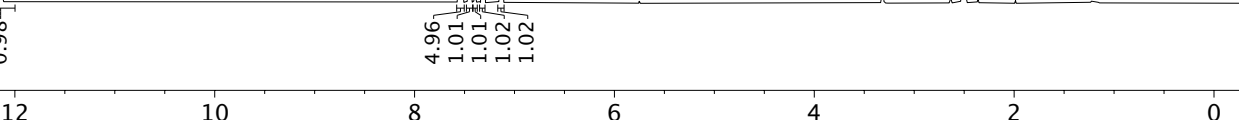

${ }^{13} \mathrm{C}$ NMR (126 MHz, DMSO- $\left.d_{6}\right)$
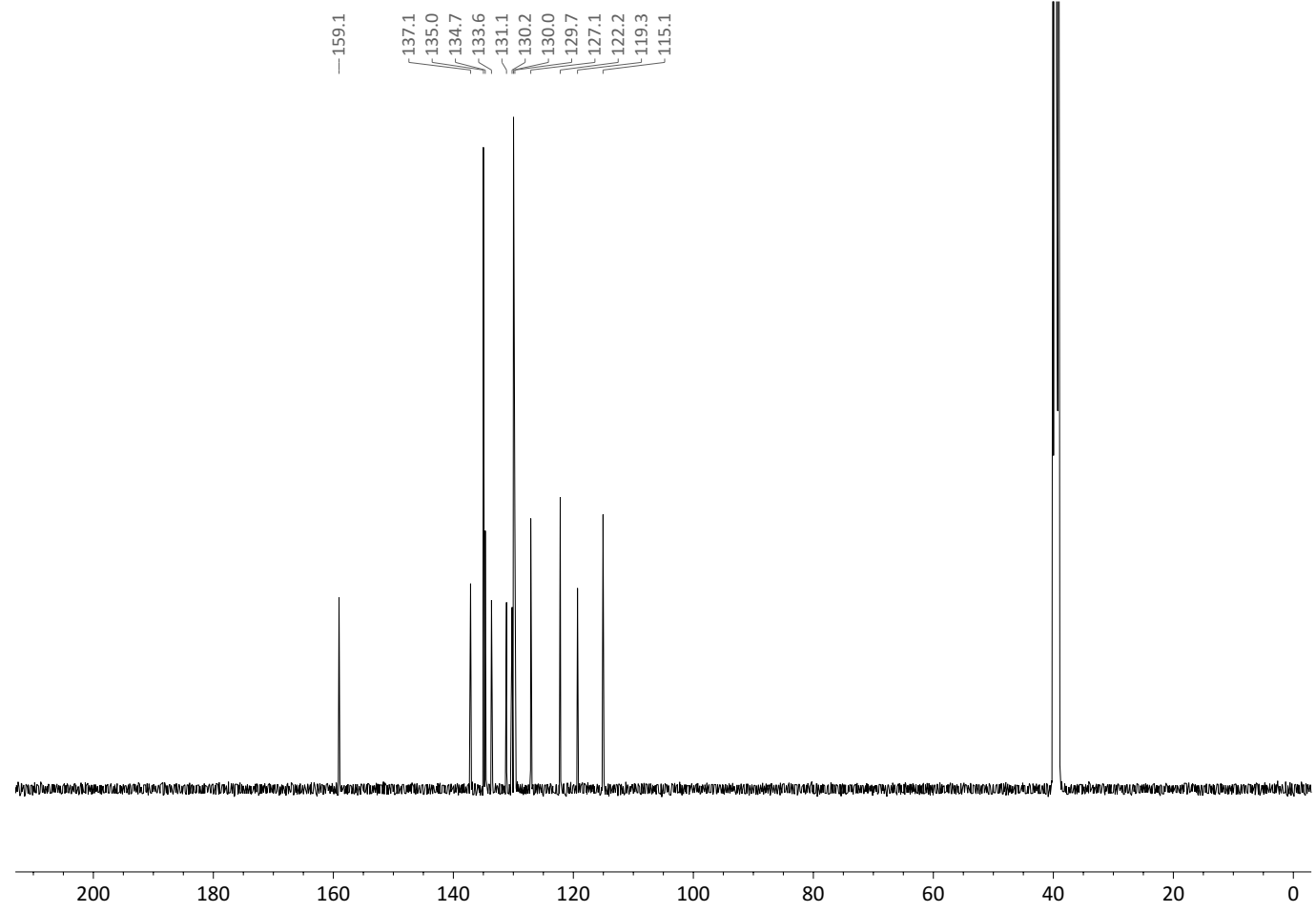
3.1.5. 3-((4-Bromophenyl)thio-2-quinolone (7e)

${ }^{1} \mathrm{H}$ NMR (500 MHz, DMSO- $\left.d_{6}\right)$

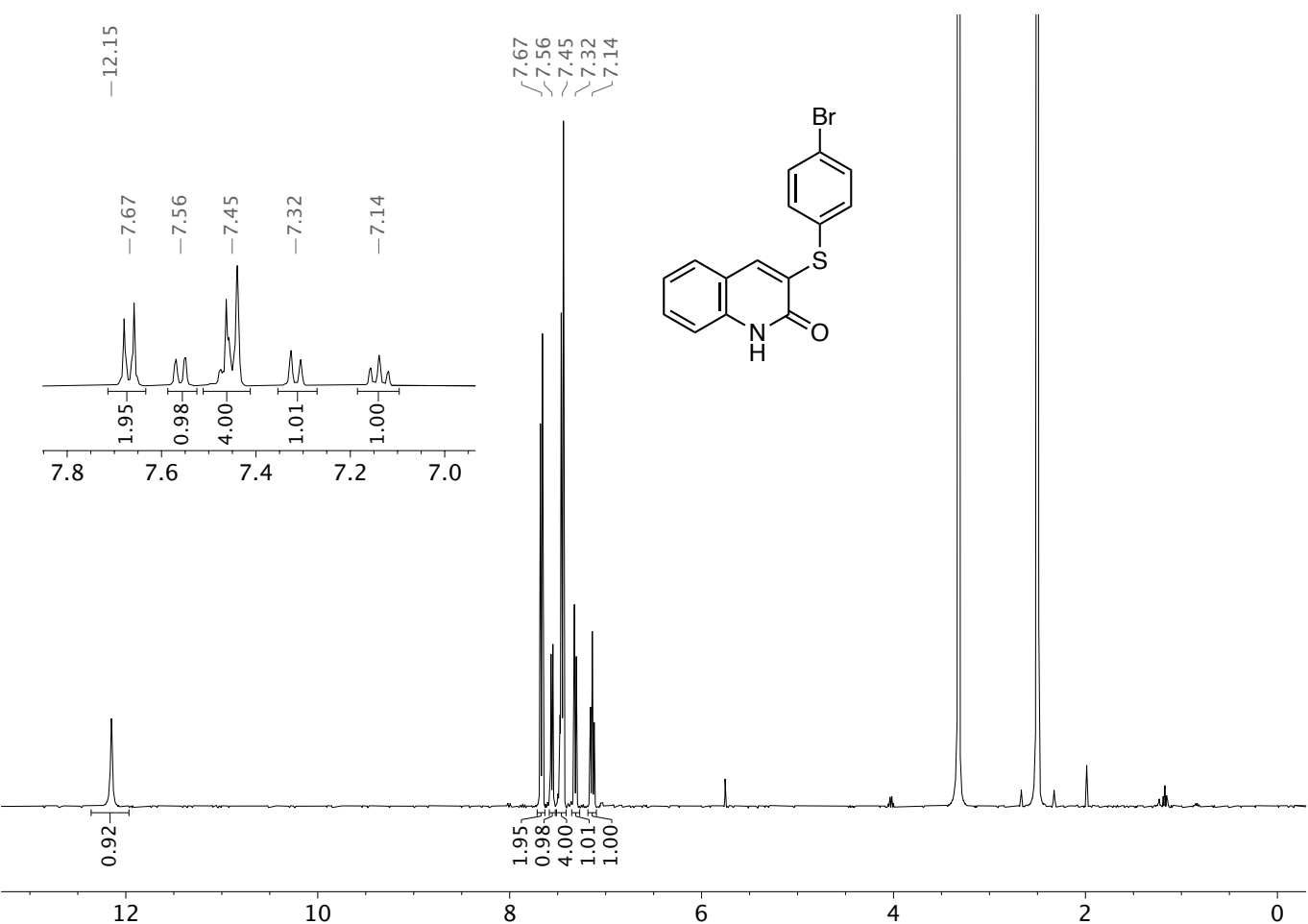

${ }^{13} \mathrm{C}$ NMR (126 MHz, DMSO- $\left.d_{6}\right)$

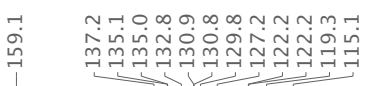

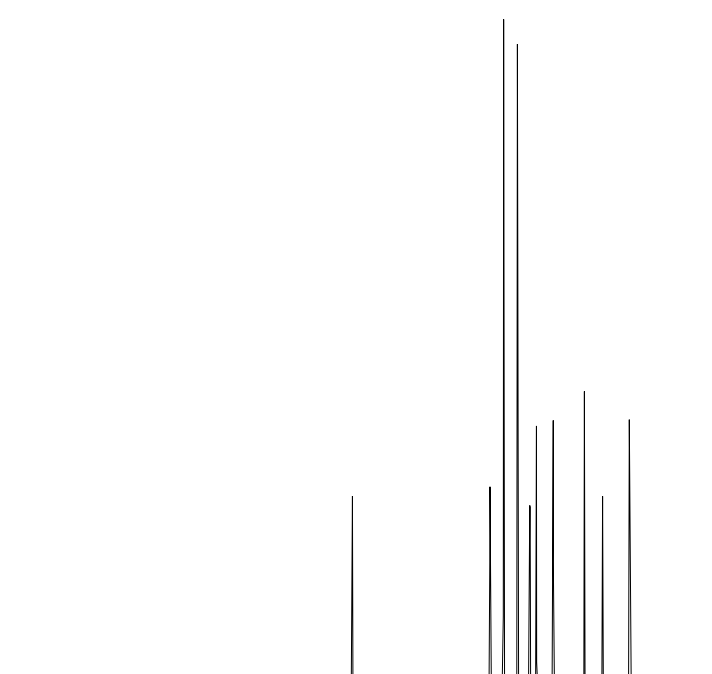

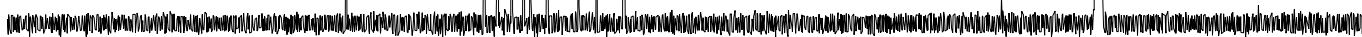


3.1.6. 3-((4-(Trifluoromethyl)phenyl)thio)-2-quinolone (7f)

${ }^{1} \mathrm{H}$ NMR (500 MHz, DMSO- $\left.d_{6}\right)$

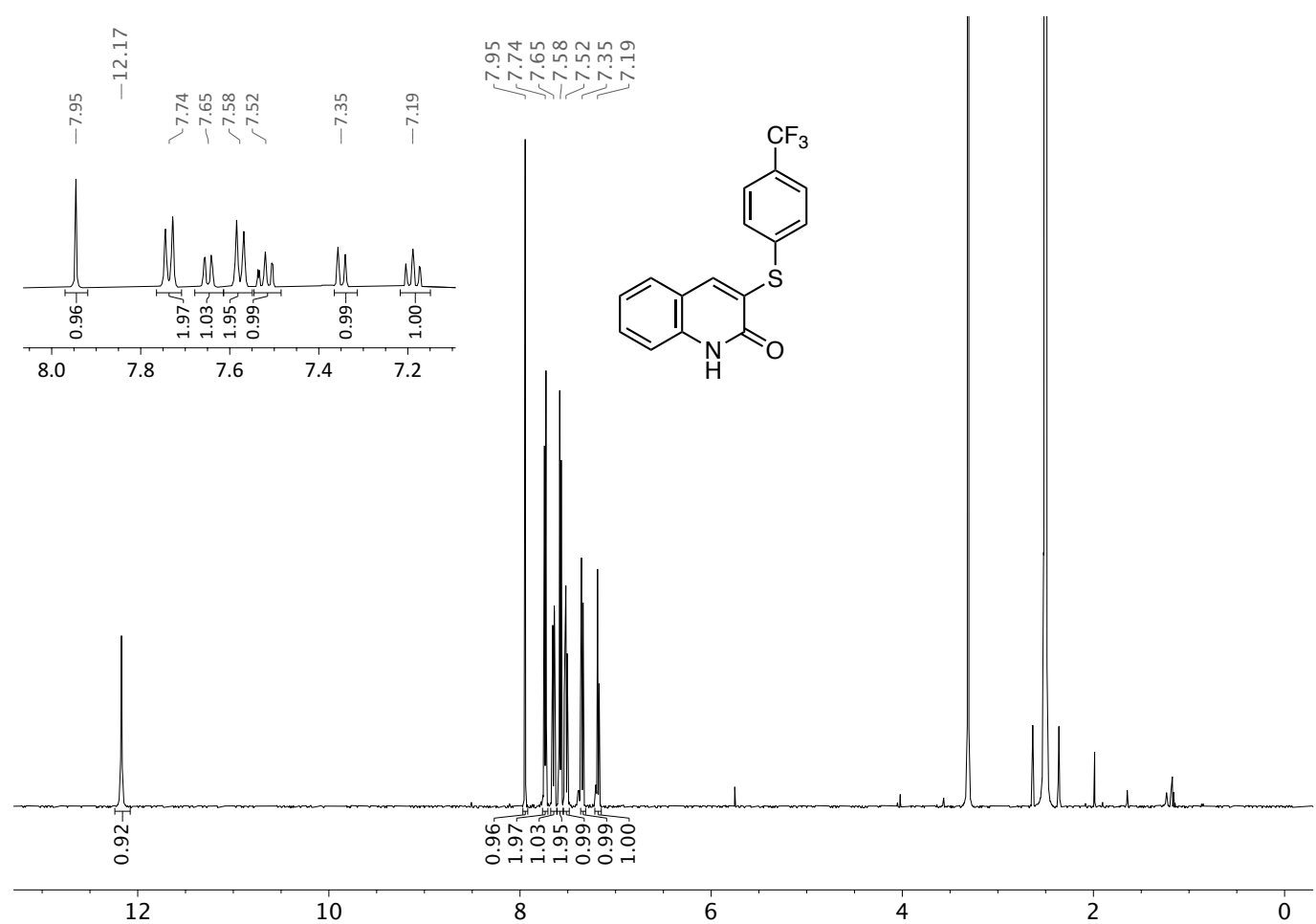

${ }^{13} \mathrm{C}$ NMR $\left(126 \mathrm{MHz}, \mathrm{DMSO}-d_{6}\right)$

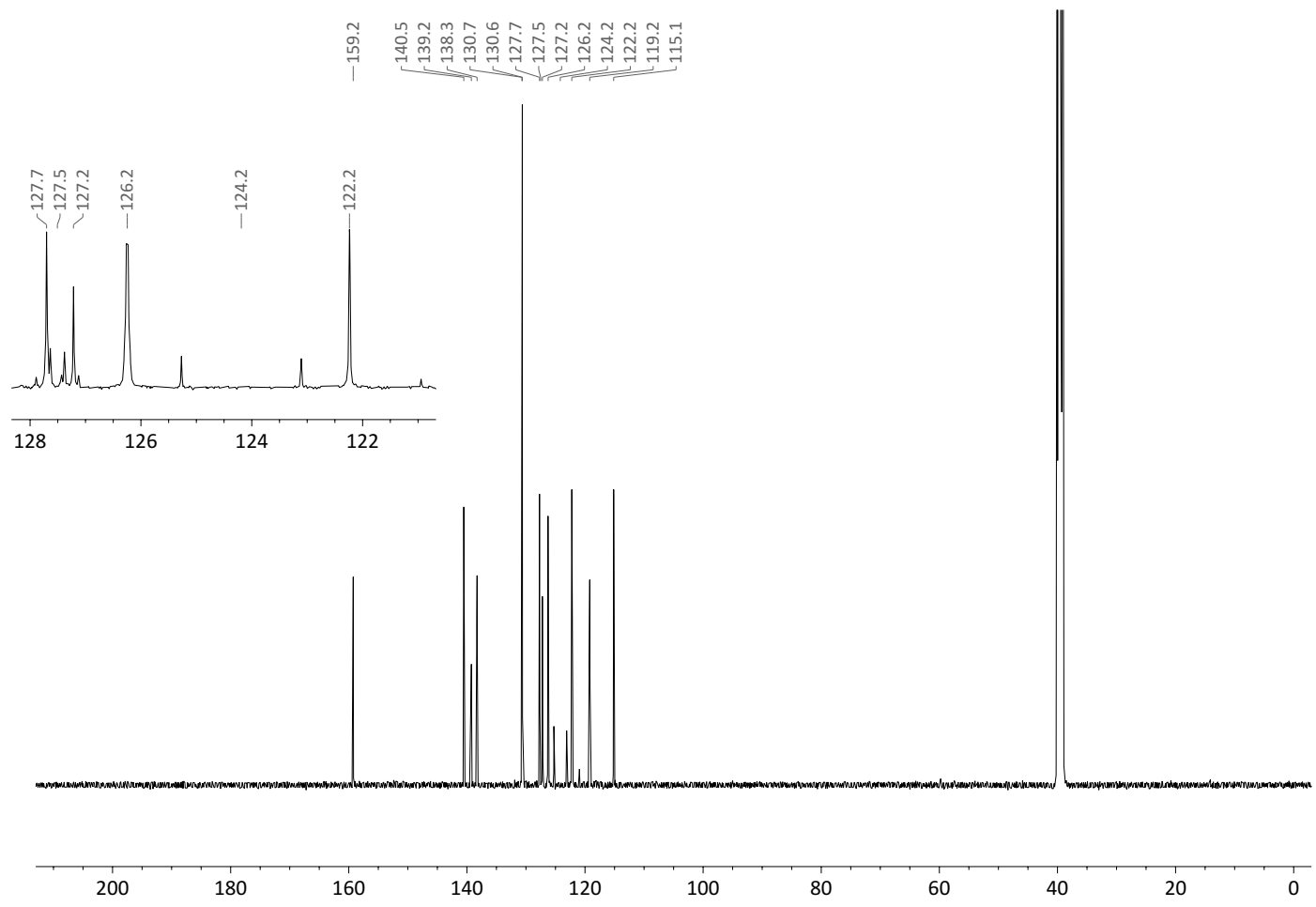


${ }^{19}$ F NMR (376 MHz, DMSO- $d_{6}$ )

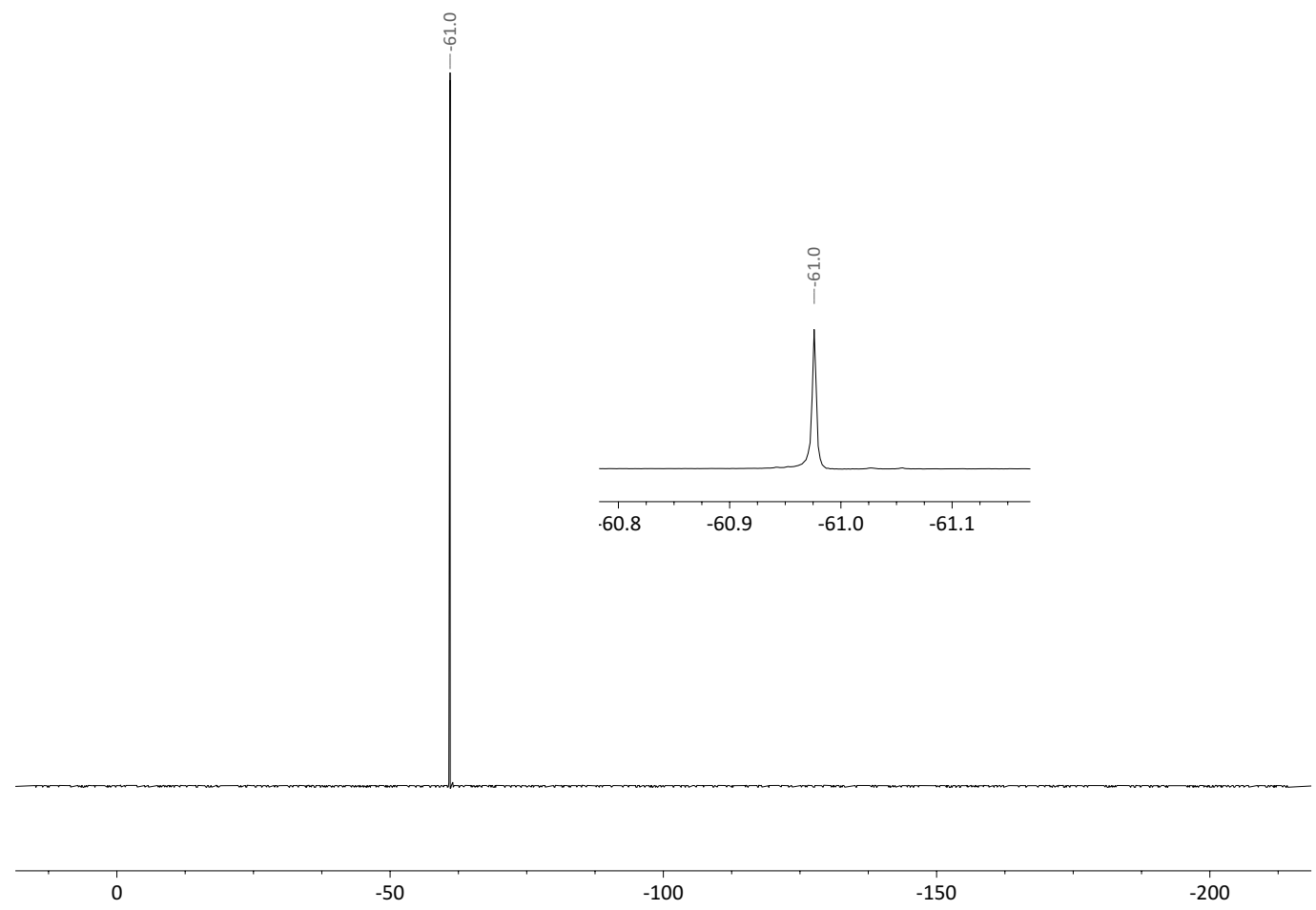


3.1.7. 6-Methyl-3-phenylthio-2-quinolone (7g)

${ }^{1} \mathrm{H}$ NMR (500 MHz, DMSO- $\left.d_{6}\right)$

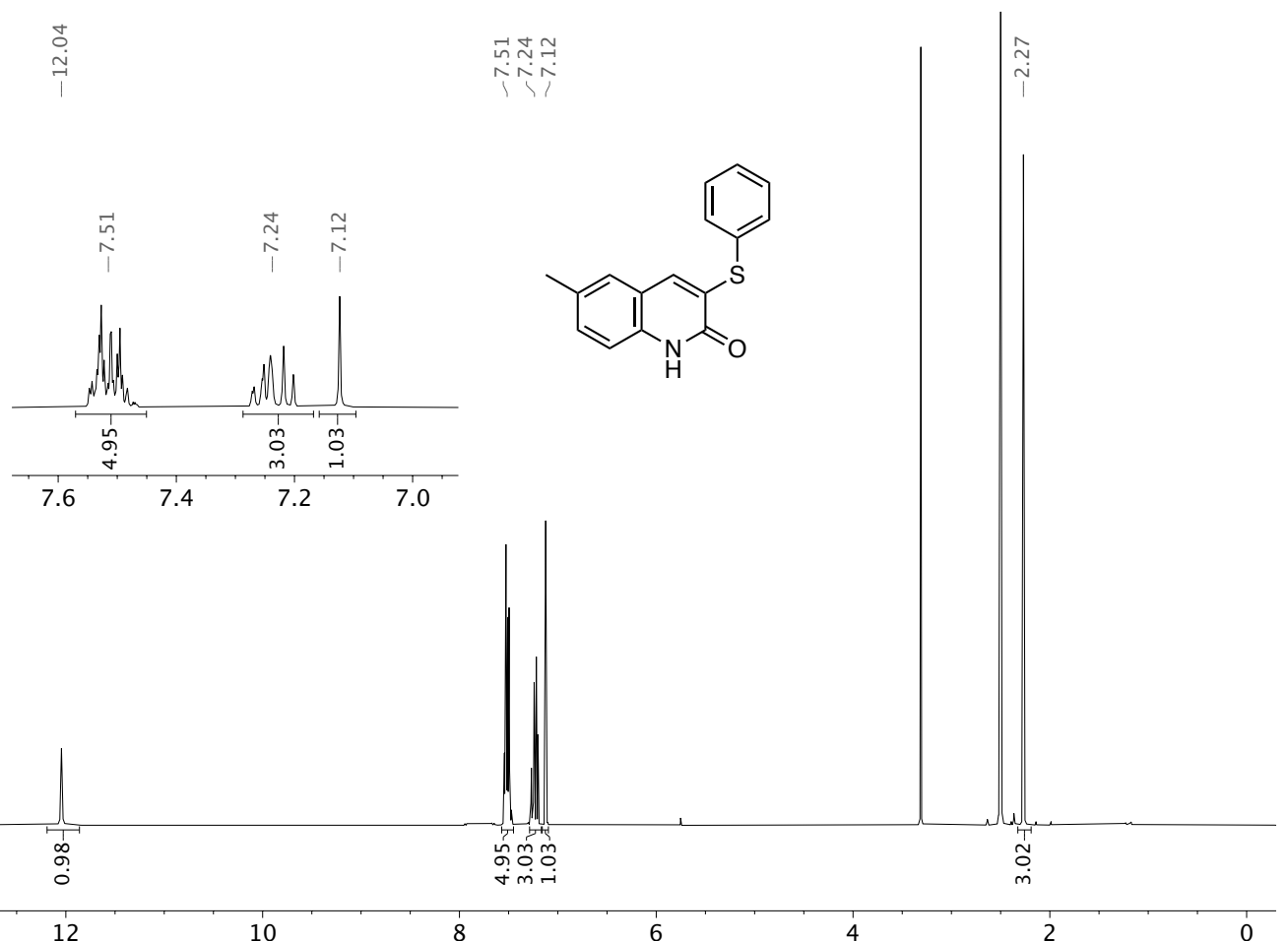

${ }^{13} \mathrm{C}$ NMR (126 MHz, DMSO- $\left.d_{6}\right)$

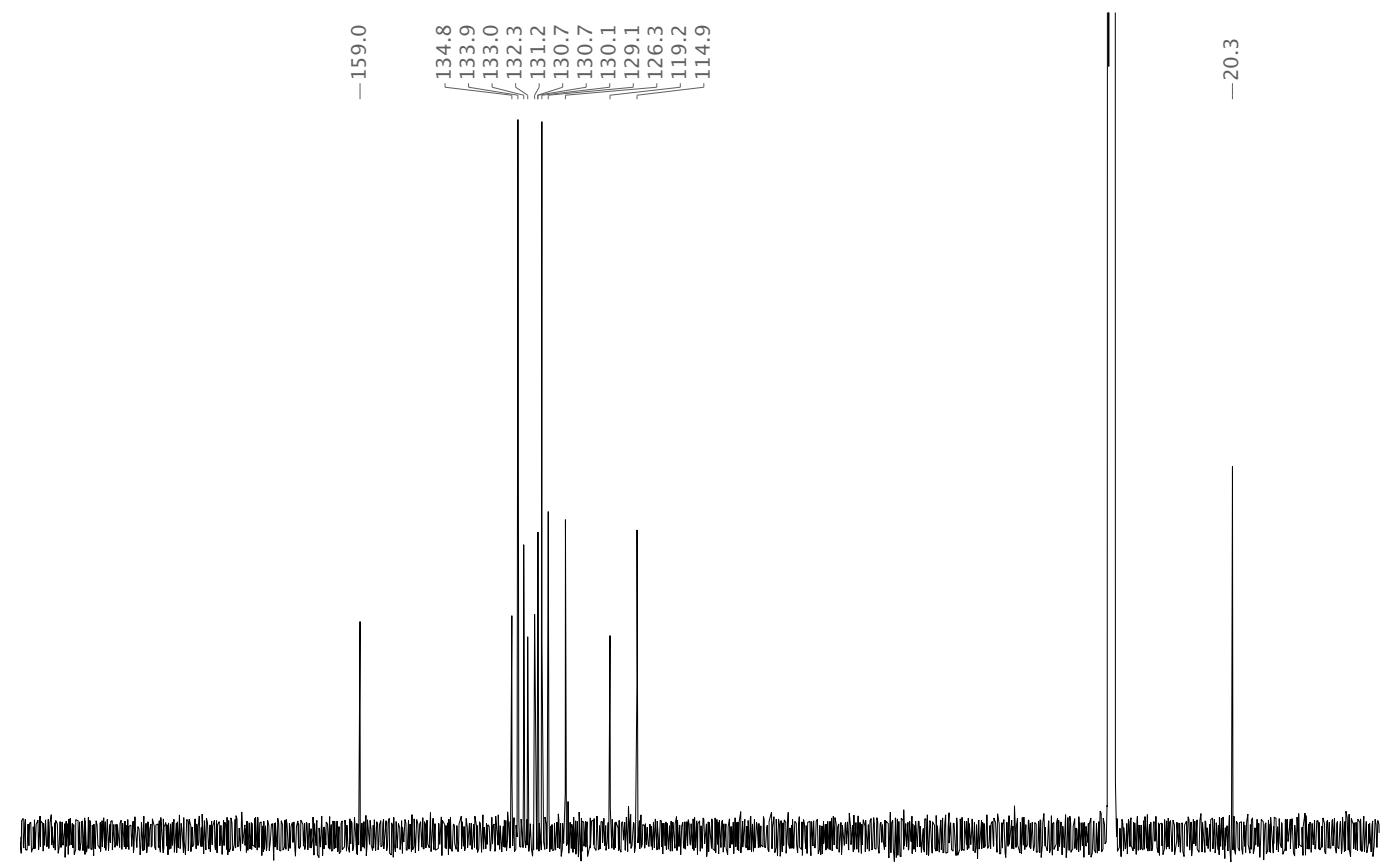

$\begin{array}{llll}200 & 180 & 160 & 140\end{array}$

120

100

80

60

40

$20 \quad 0$ 
3.1.8. 7-Methyl-3-phenylthio-2-quinolone (7h)

${ }^{1} \mathrm{H}$ NMR (500 MHz, DMSO- $\left.d_{6}\right)$
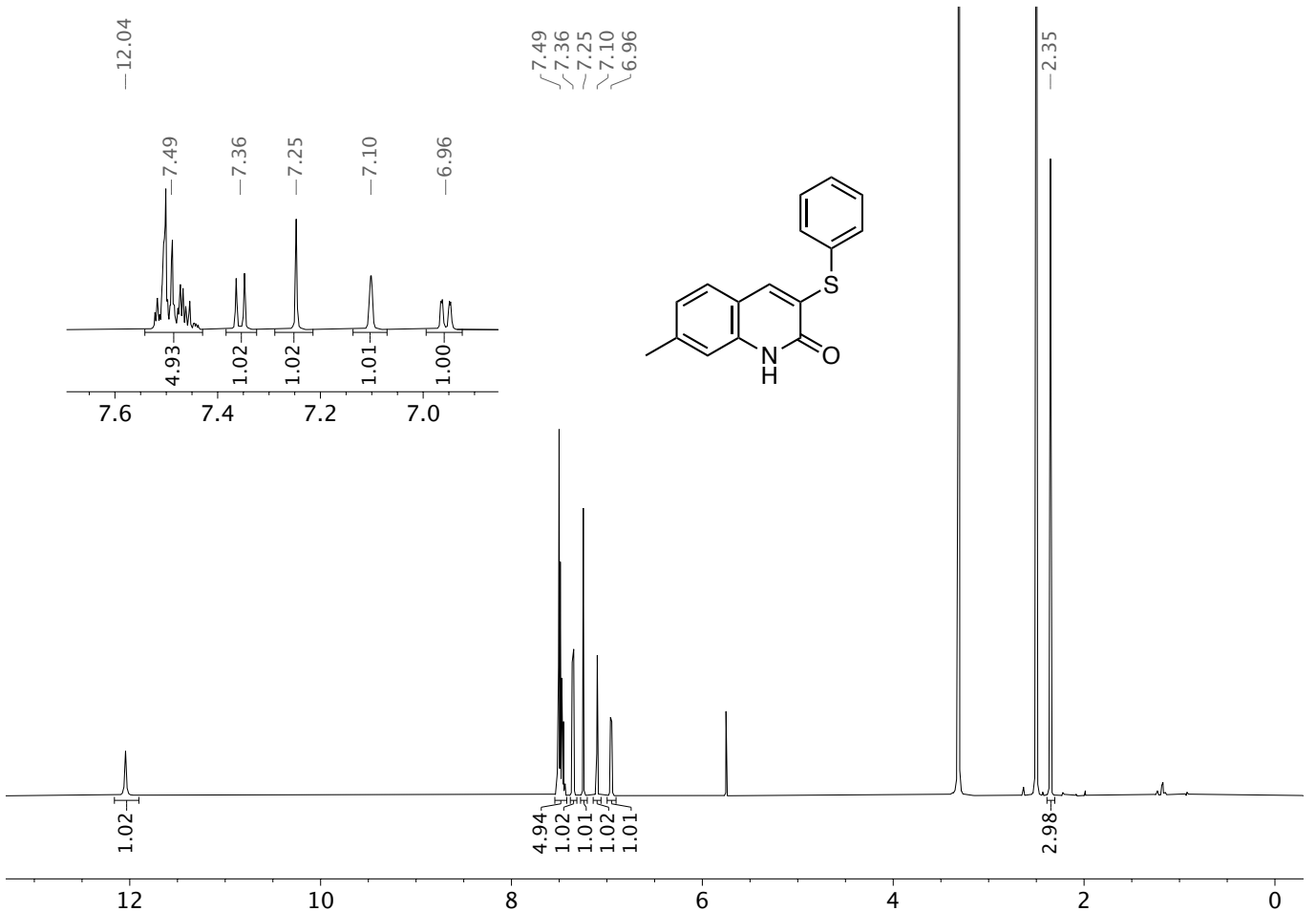

${ }^{13} \mathrm{C}$ NMR (126 MHz, DMSO- $\left.d_{6}\right)$

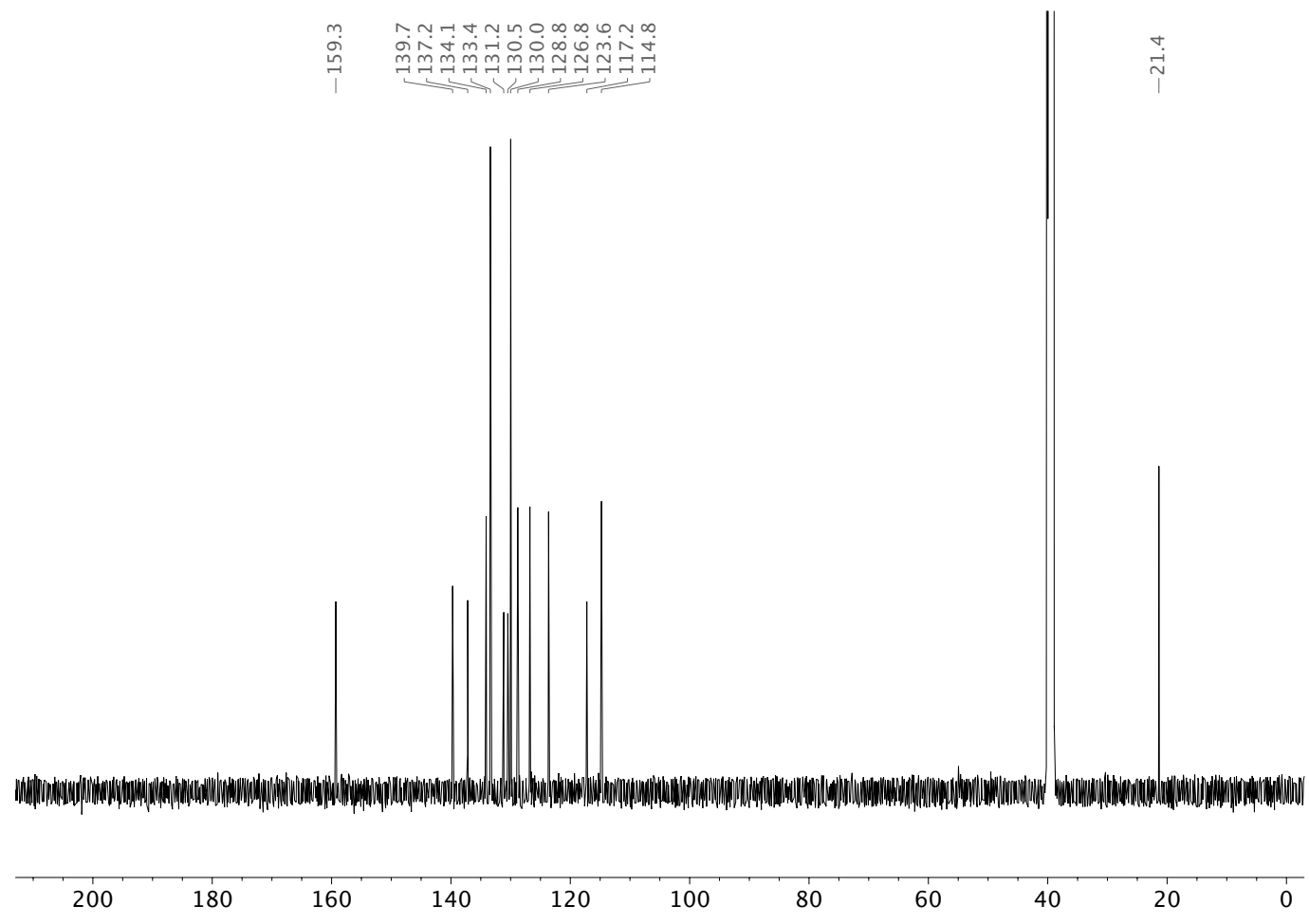


3.1.9. 3-(Naphthalen-2-ylthio)-2-quinolone (7i)

${ }^{1} \mathrm{H}$ NMR (500 MHz, DMSO- $\left.d_{6}\right)$

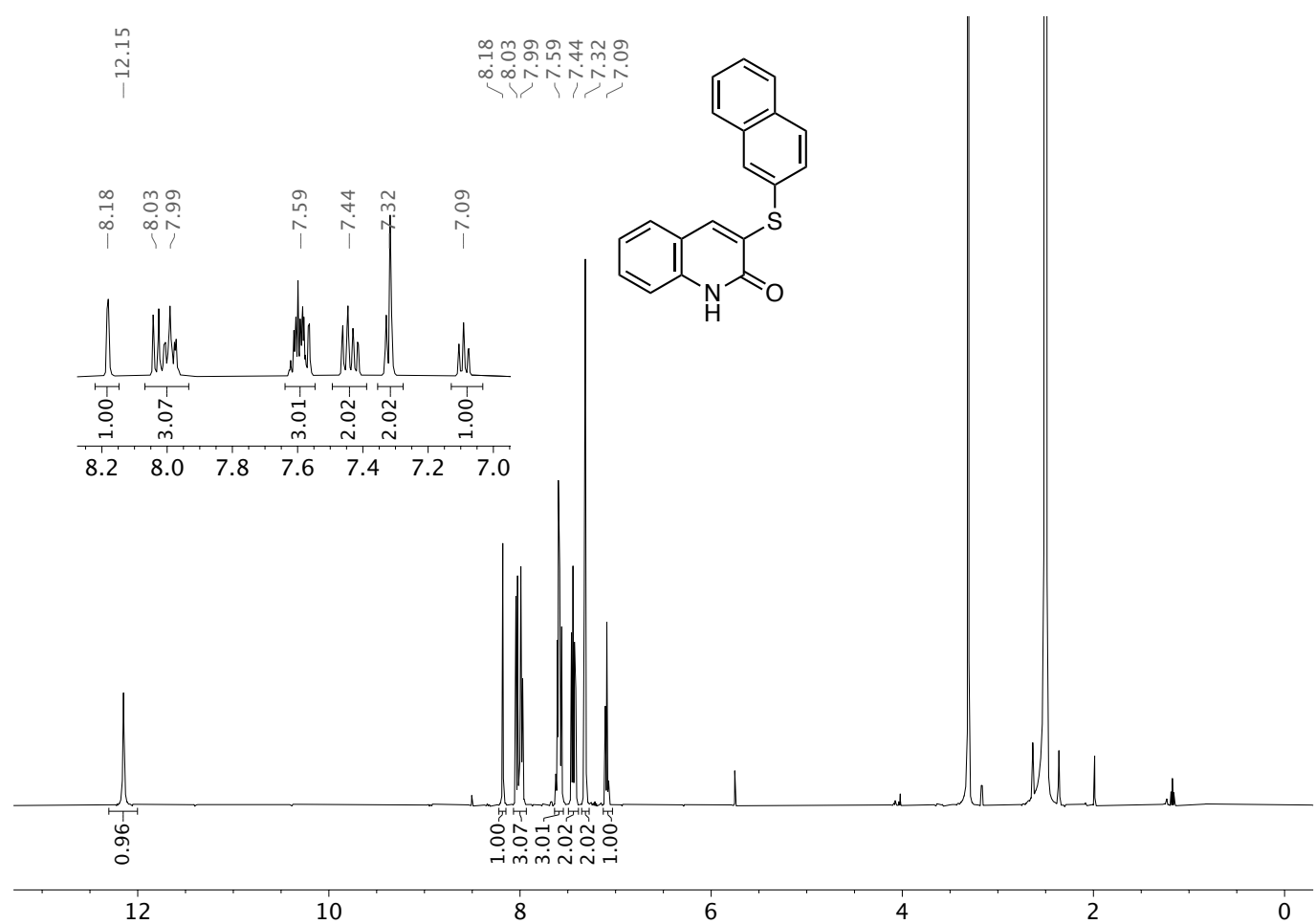

${ }^{13} \mathrm{C}$ NMR (126 MHz, DMSO- $\left.d_{6}\right)$

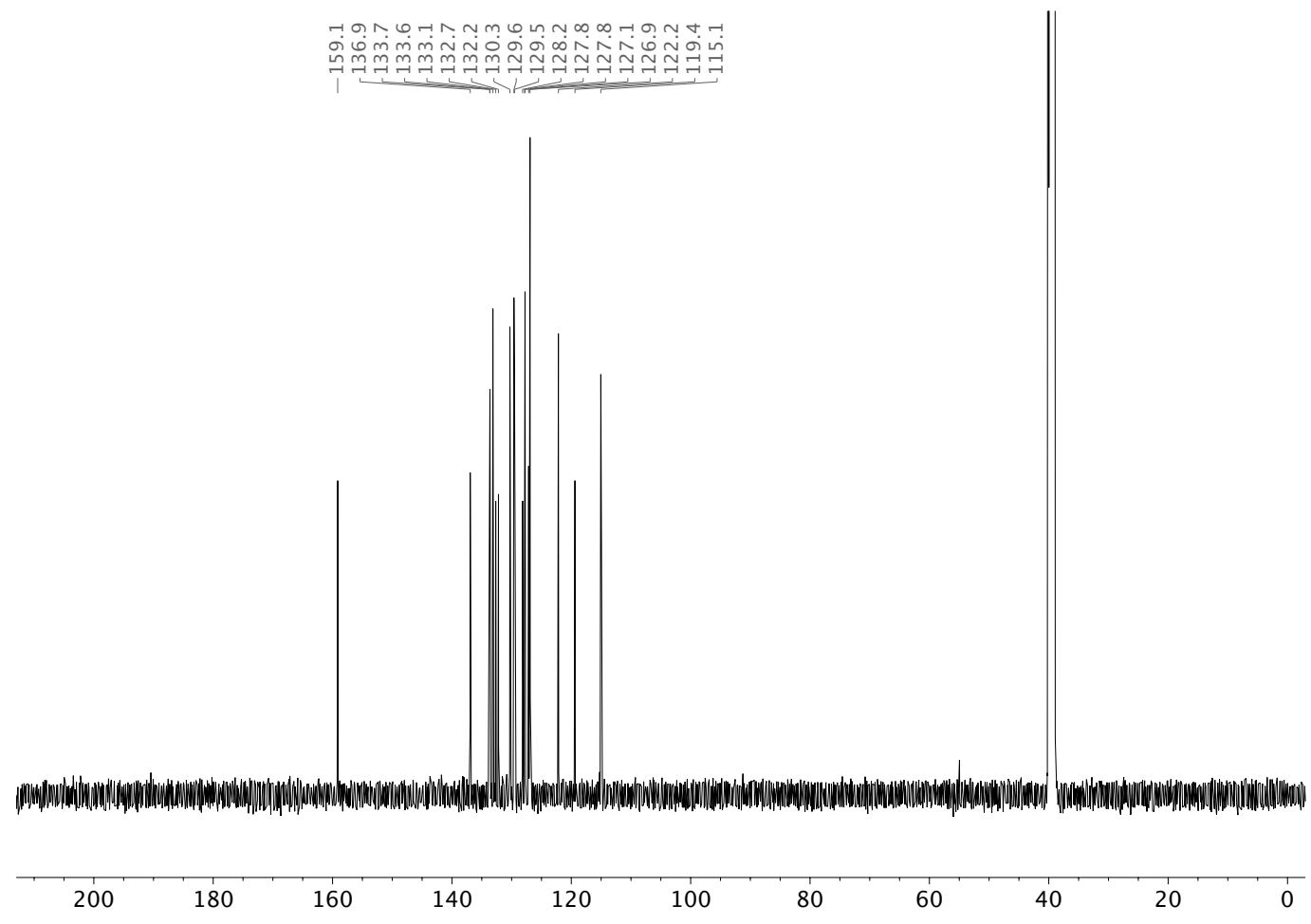


3.1.10. 3-(m-Tolylthio)-2-quinolone (7j)

${ }^{1} \mathrm{H}$ NMR (500 MHz, DMSO- $d_{6}$ )

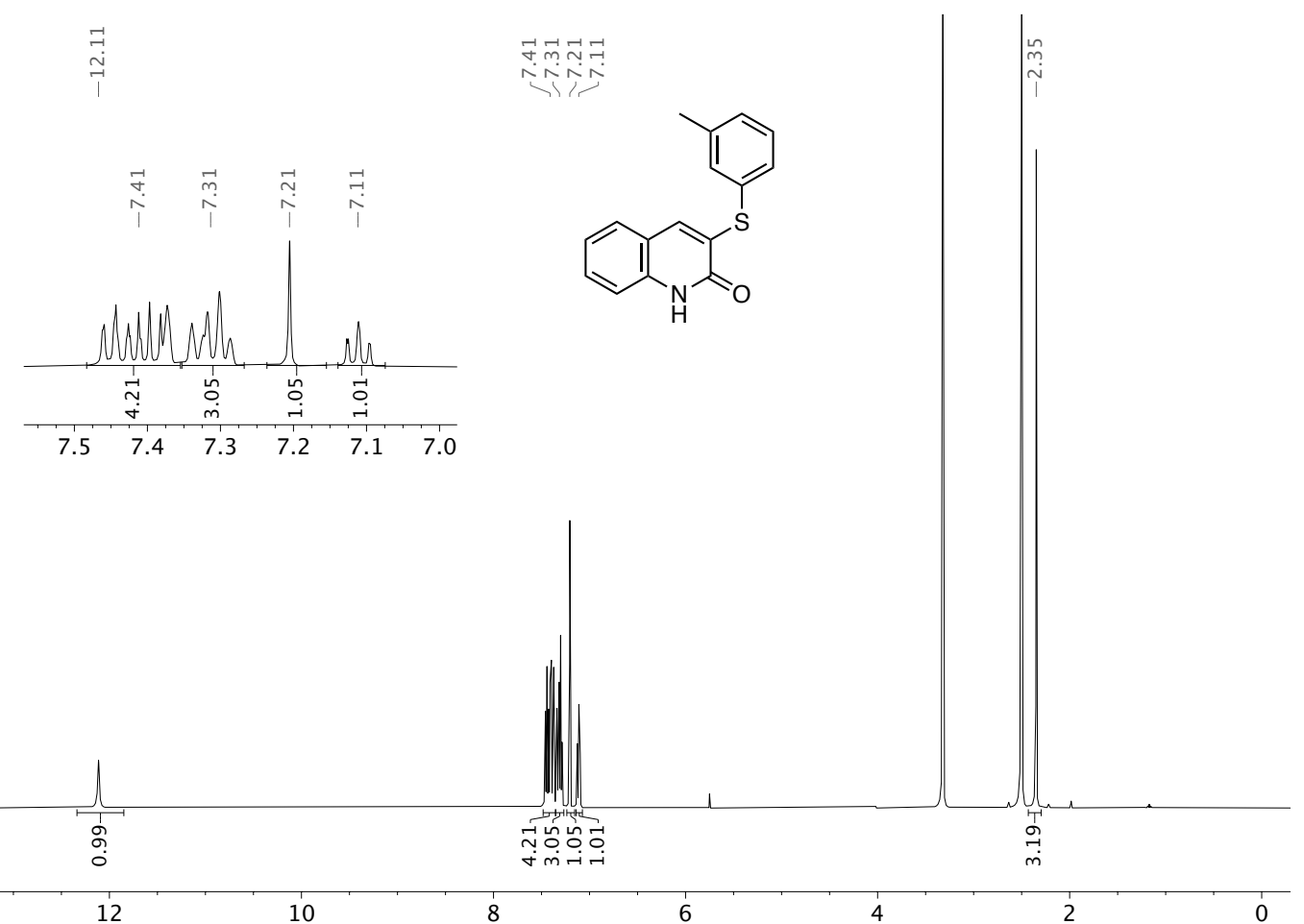

${ }^{13} \mathrm{C}$ NMR (126 MHz, DMSO- $\left.d_{6}\right)$

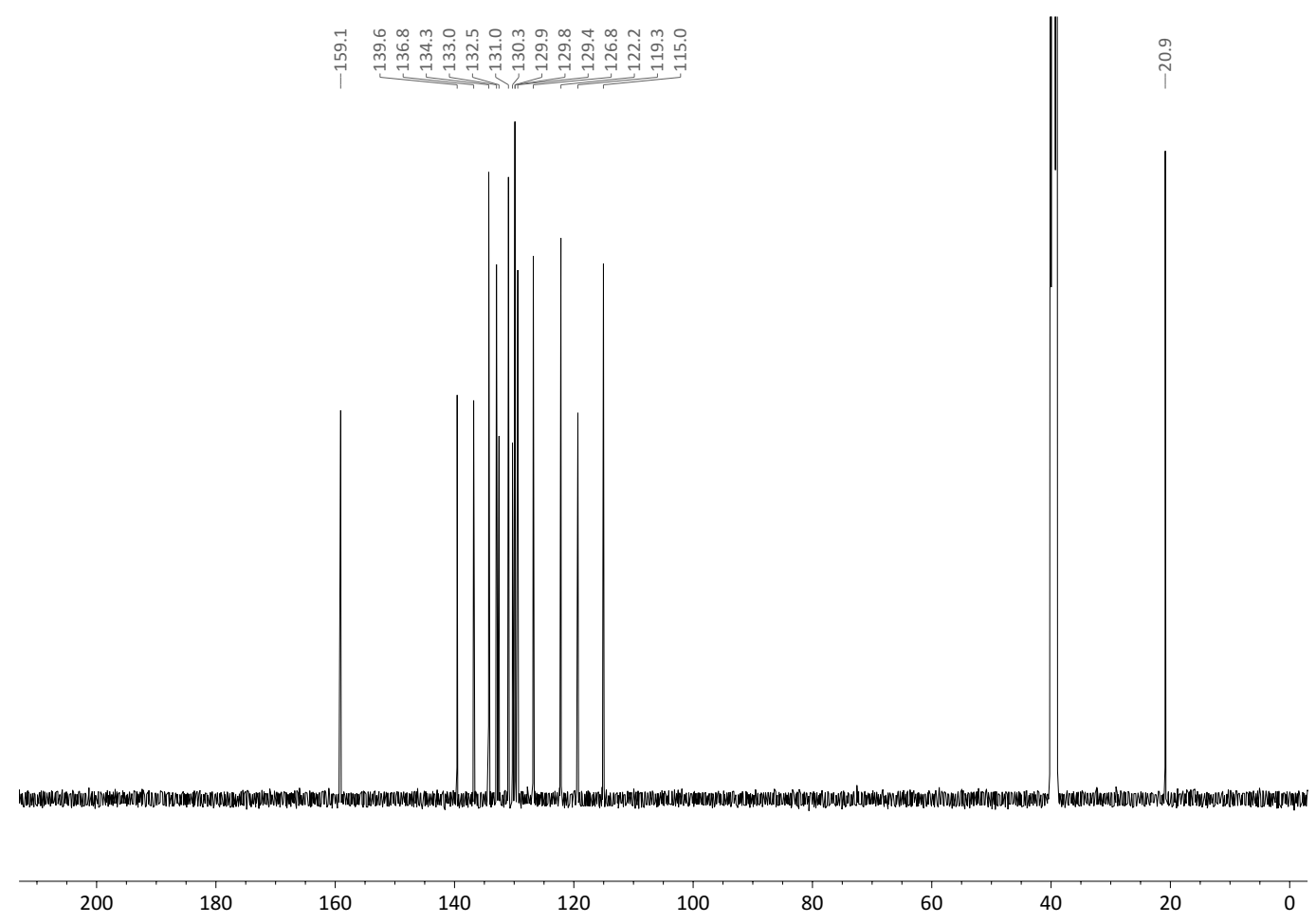


3.1.11. 3-((3-Fluorophenyl)thio)-2-quinolone (7k)

${ }^{1} \mathrm{H}$ NMR (500 MHz, DMSO- $\left.d_{6}\right)$

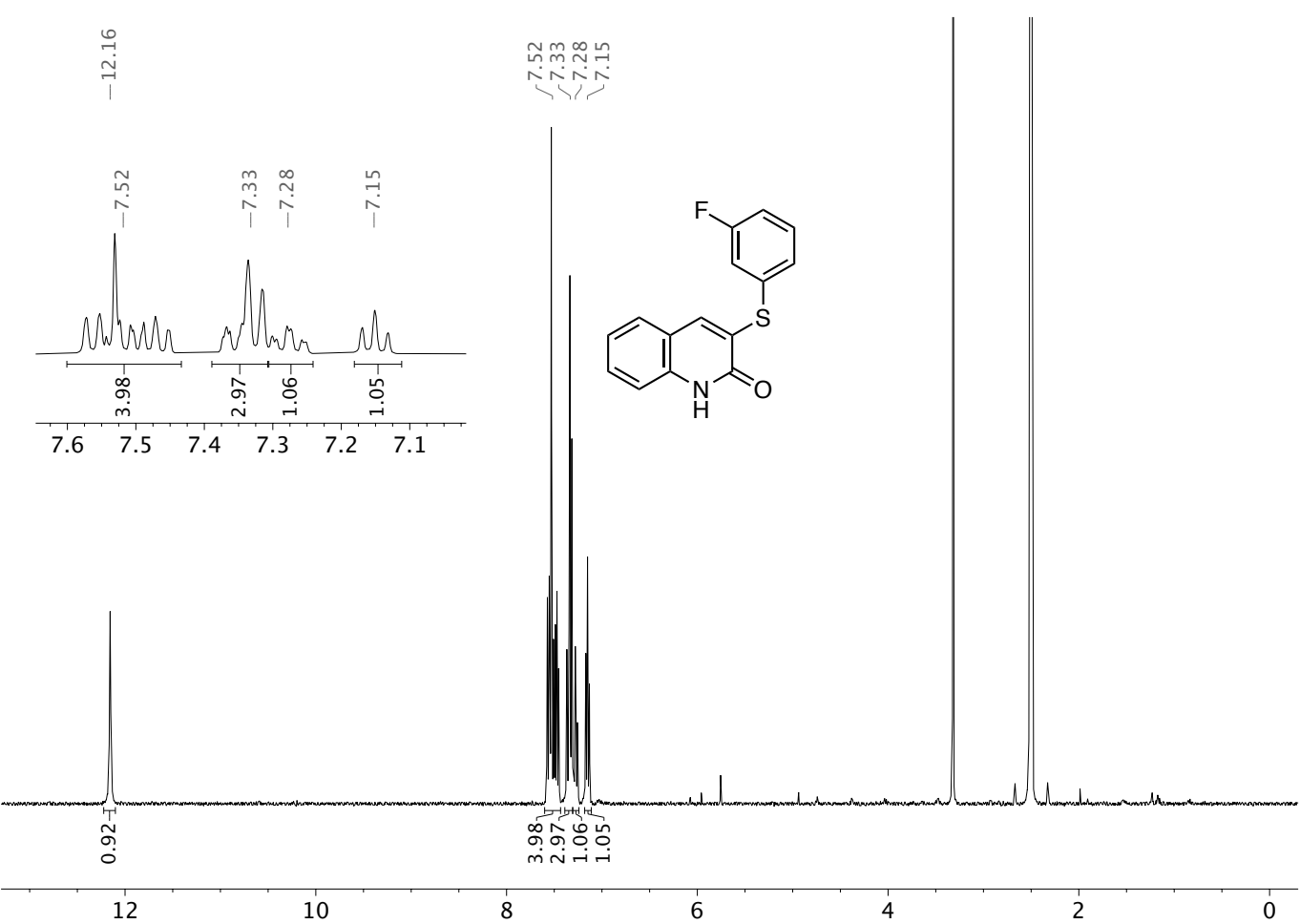

${ }^{13} \mathrm{C}$ NMR $\left(126 \mathrm{MHz}, \mathrm{DMSO}-d_{6}\right)$

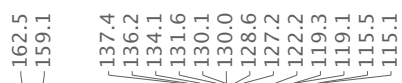

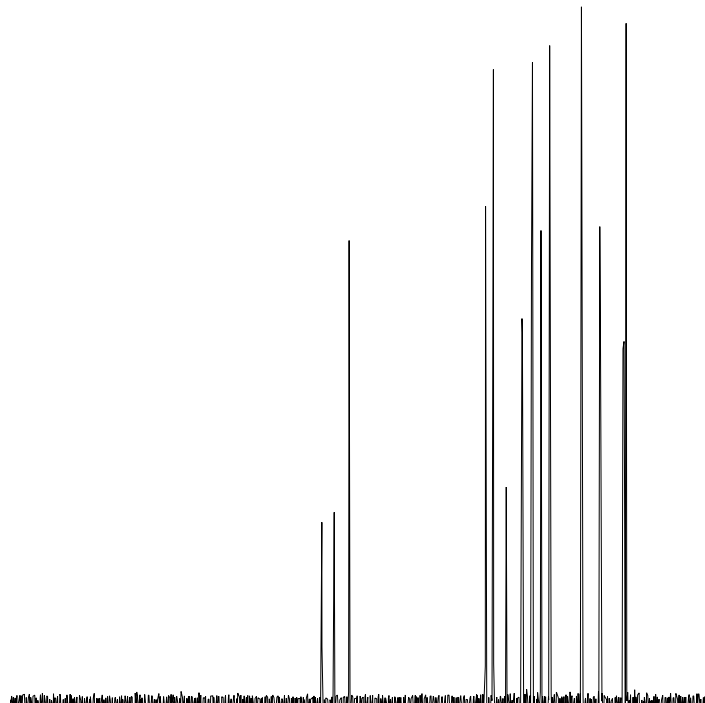

$20 \quad 100$

80

60

40 
${ }^{19}$ F NMR (376 MHz, DMSO- $\left.d_{6}\right)$

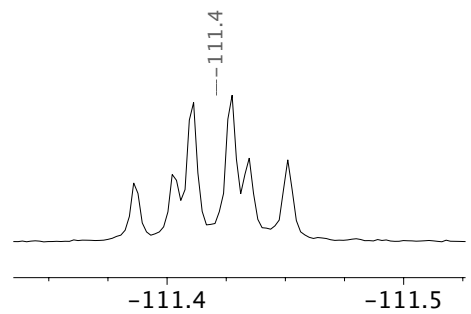

$-50$

$-100$

$-150$

$-200$ 
3.1.12. 3-(o-Tolylthio)-2-quinolone (기)

${ }^{1} \mathrm{H}$ NMR $\left(500 \mathrm{MHz}, \mathrm{DMSO}-d_{6}\right)$

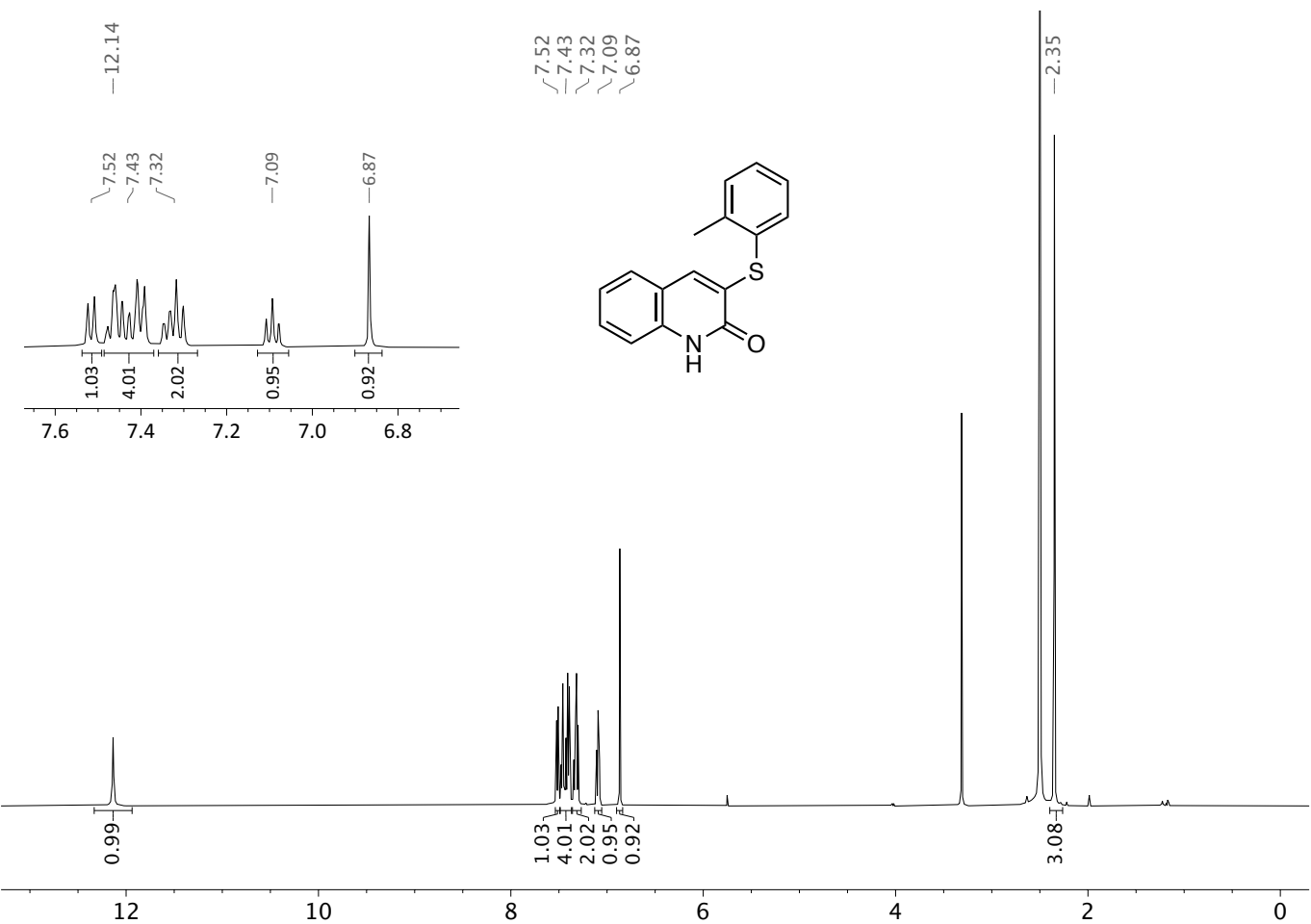

${ }^{13} \mathrm{C}$ NMR $\left(126 \mathrm{MHz}, \mathrm{DMSO}-d_{6}\right)$

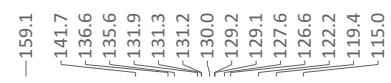

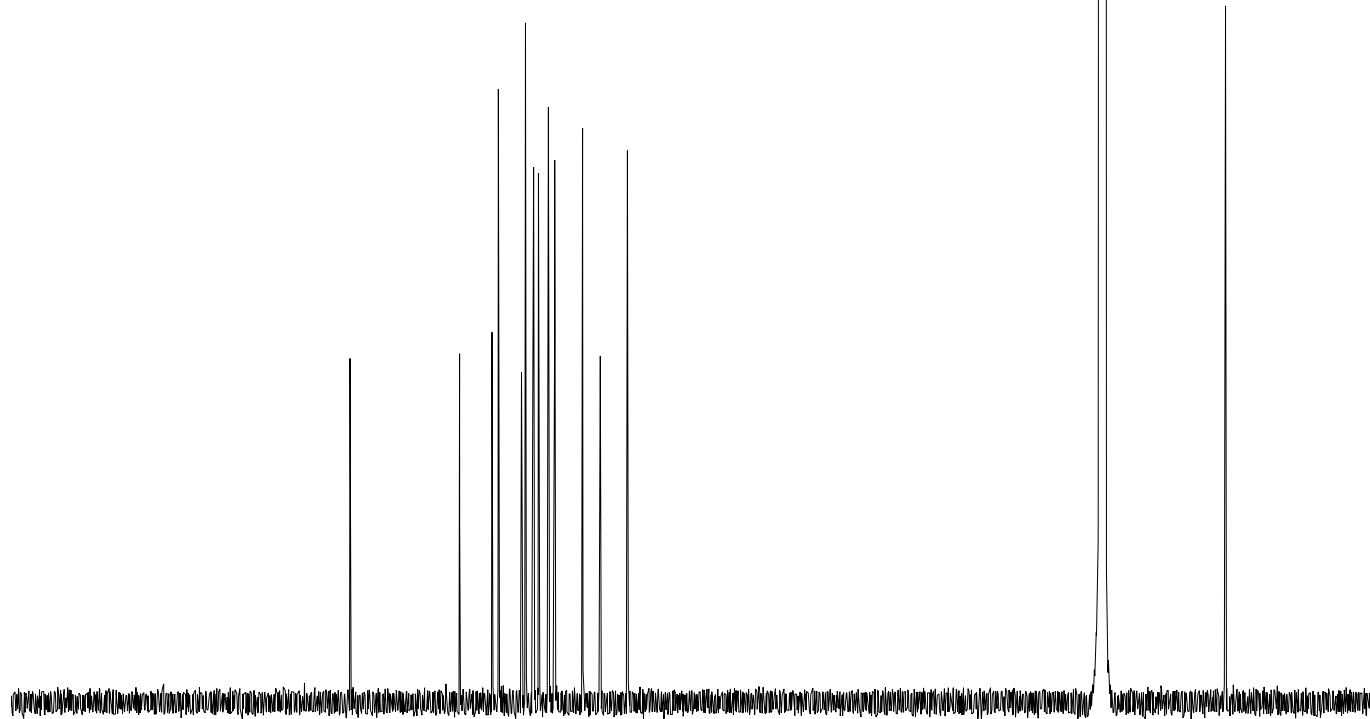

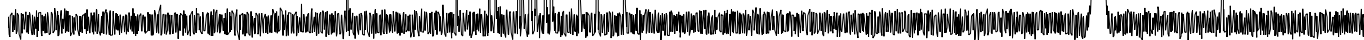

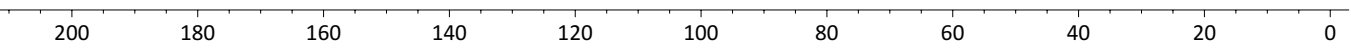


3.1.13. 3-((2-Ethylphenyl)thio)-2-quinolone (7m)

${ }^{1} \mathrm{H}$ NMR (500 MHz, DMSO-d $)$

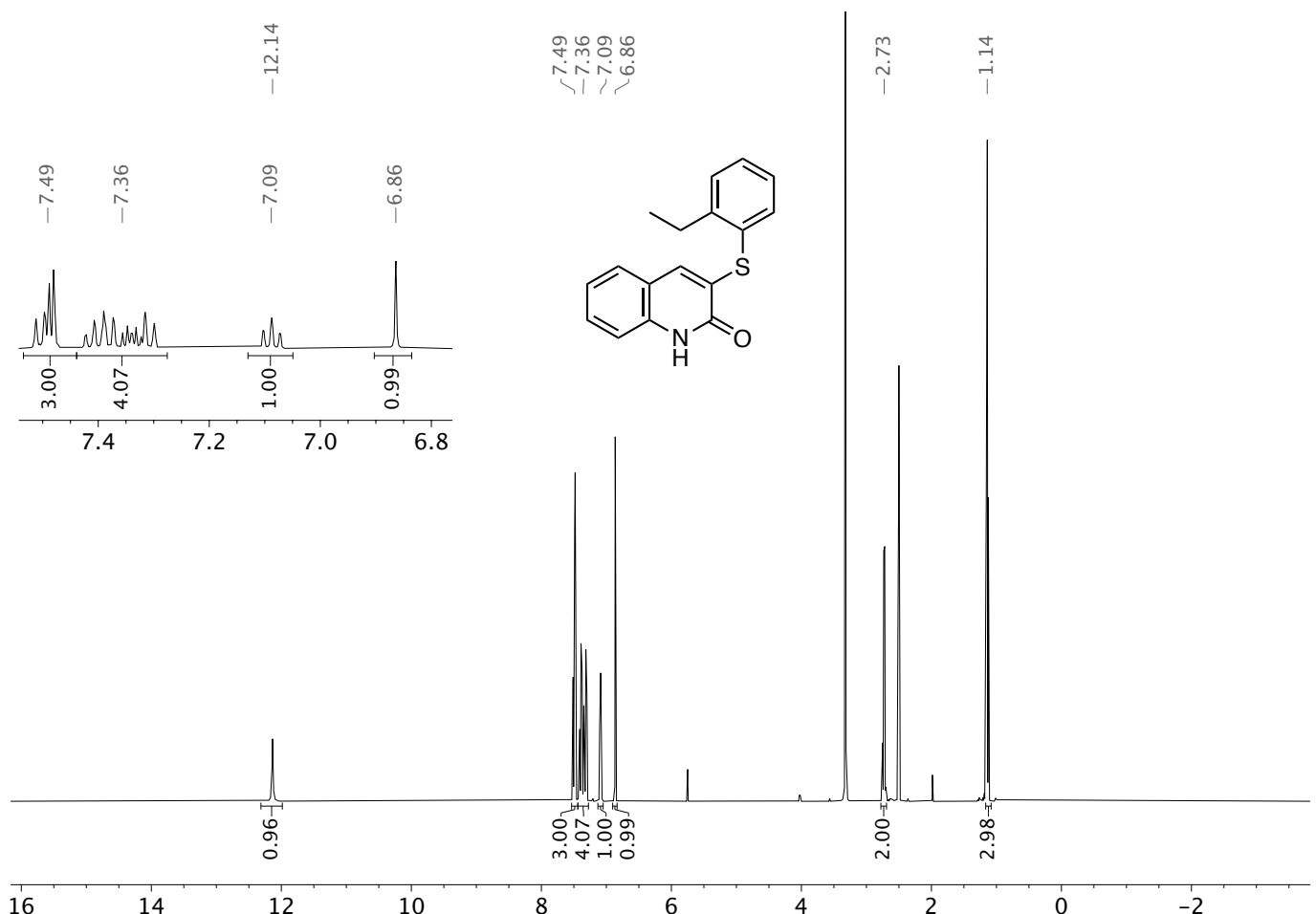

${ }^{13} \mathrm{C}$ NMR (126 MHz, DMSO- $\left.d_{6}\right)$

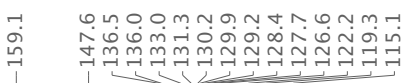

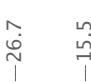

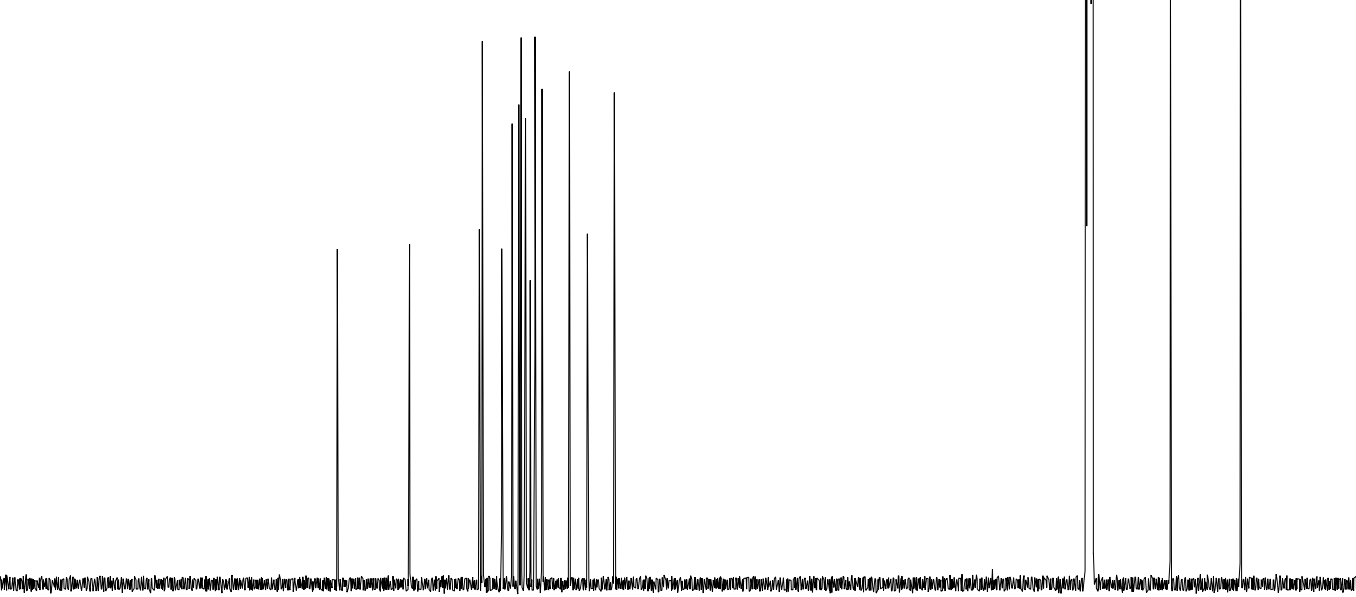

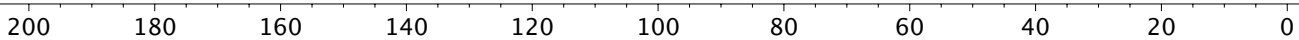


3.1.14. 3-((2-Methoxyphenyl)thio)-2-quinolone (7n)

${ }^{1} \mathrm{H}$ NMR (500 MHz, DMSO- $\left.d_{6}\right)$

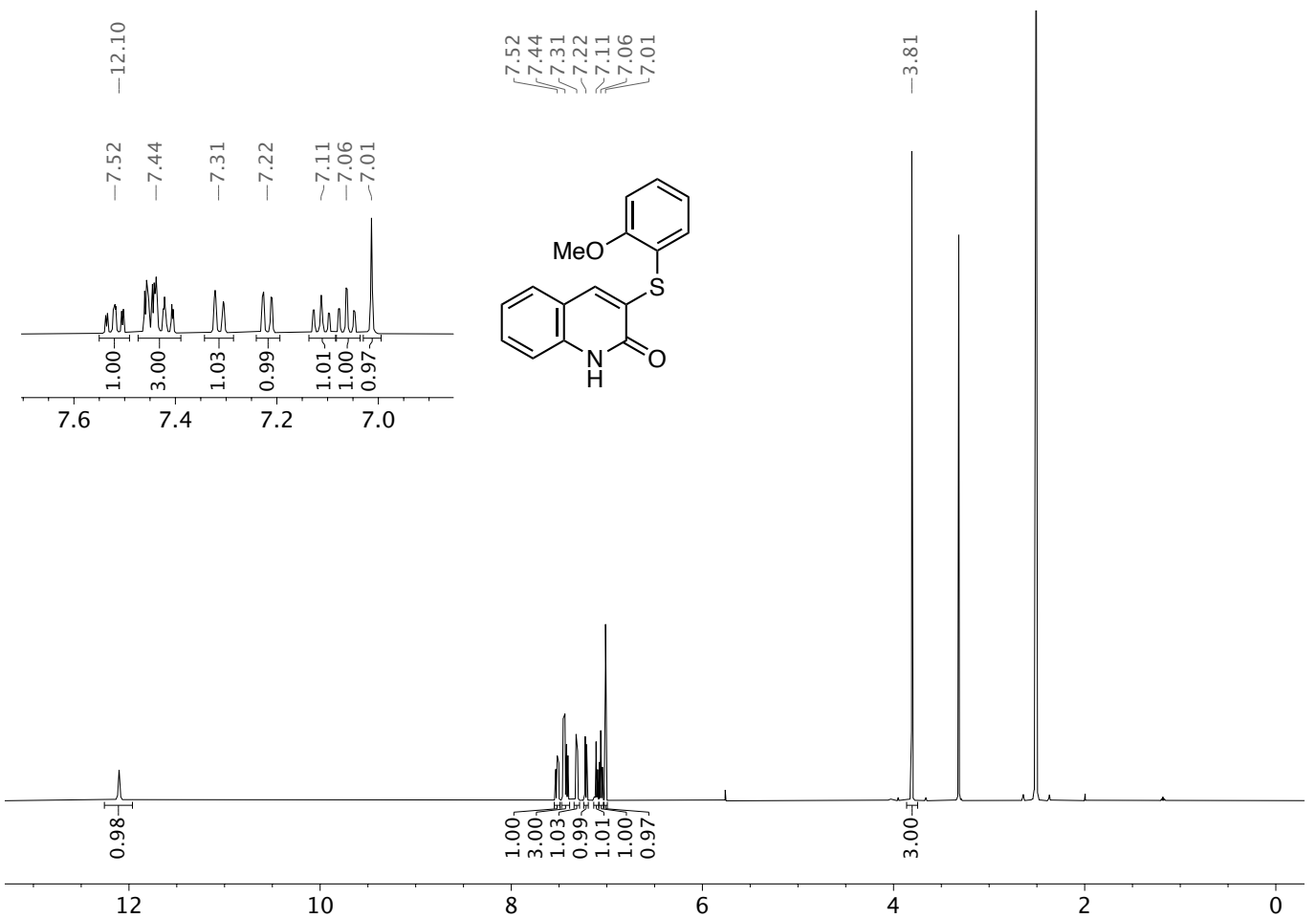

${ }^{13} \mathrm{C}$ NMR (126 MHz, DMSO- $\left.d_{6}\right)$

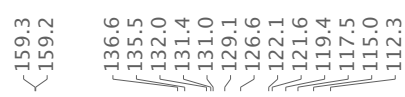

in

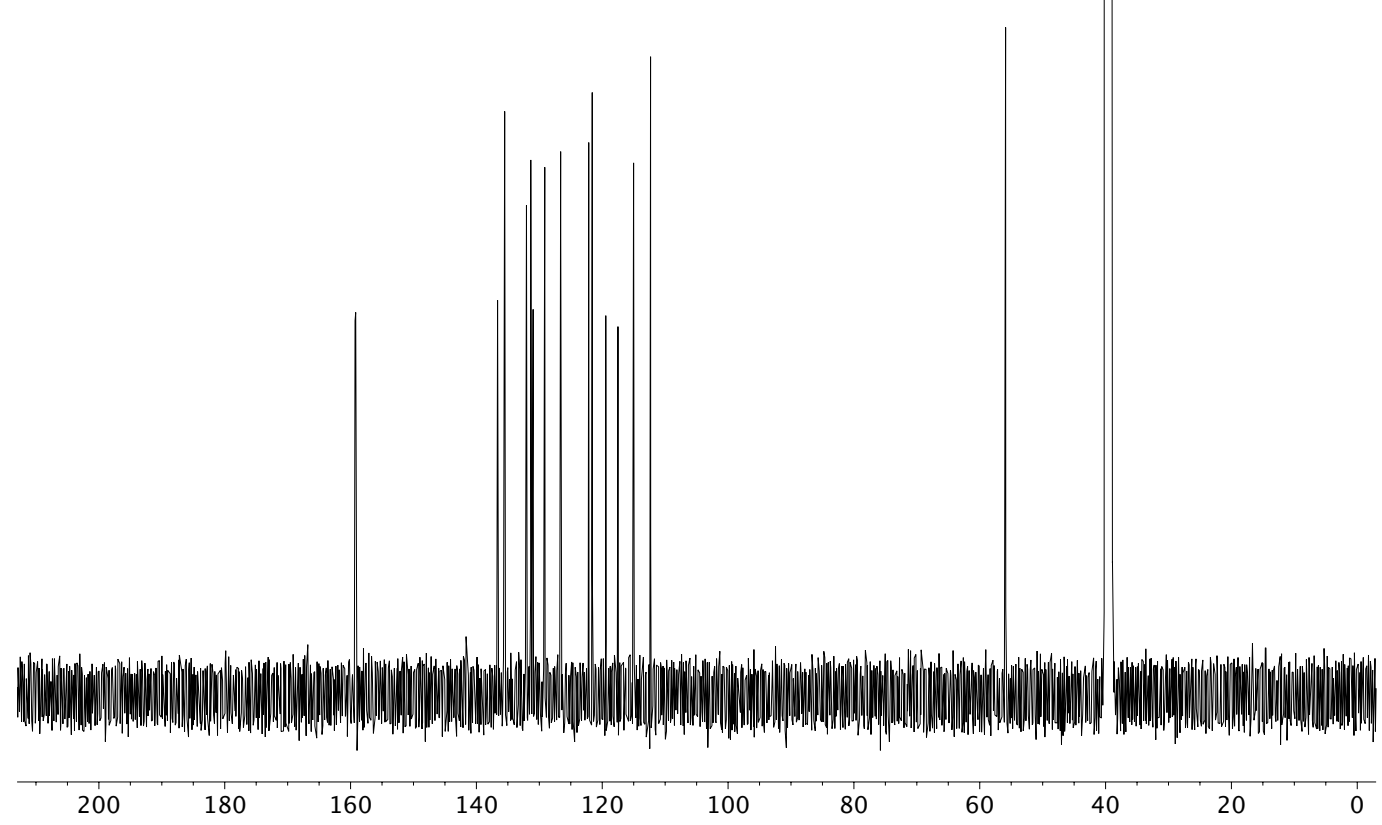


3.1.15. 3-((2,6-Dimethylphenyl)thio)-2-quinolone (7o)

${ }^{1} \mathrm{H}$ NMR $\left(500 \mathrm{MHz}\right.$, DMSO- $\left.d_{6}\right)$

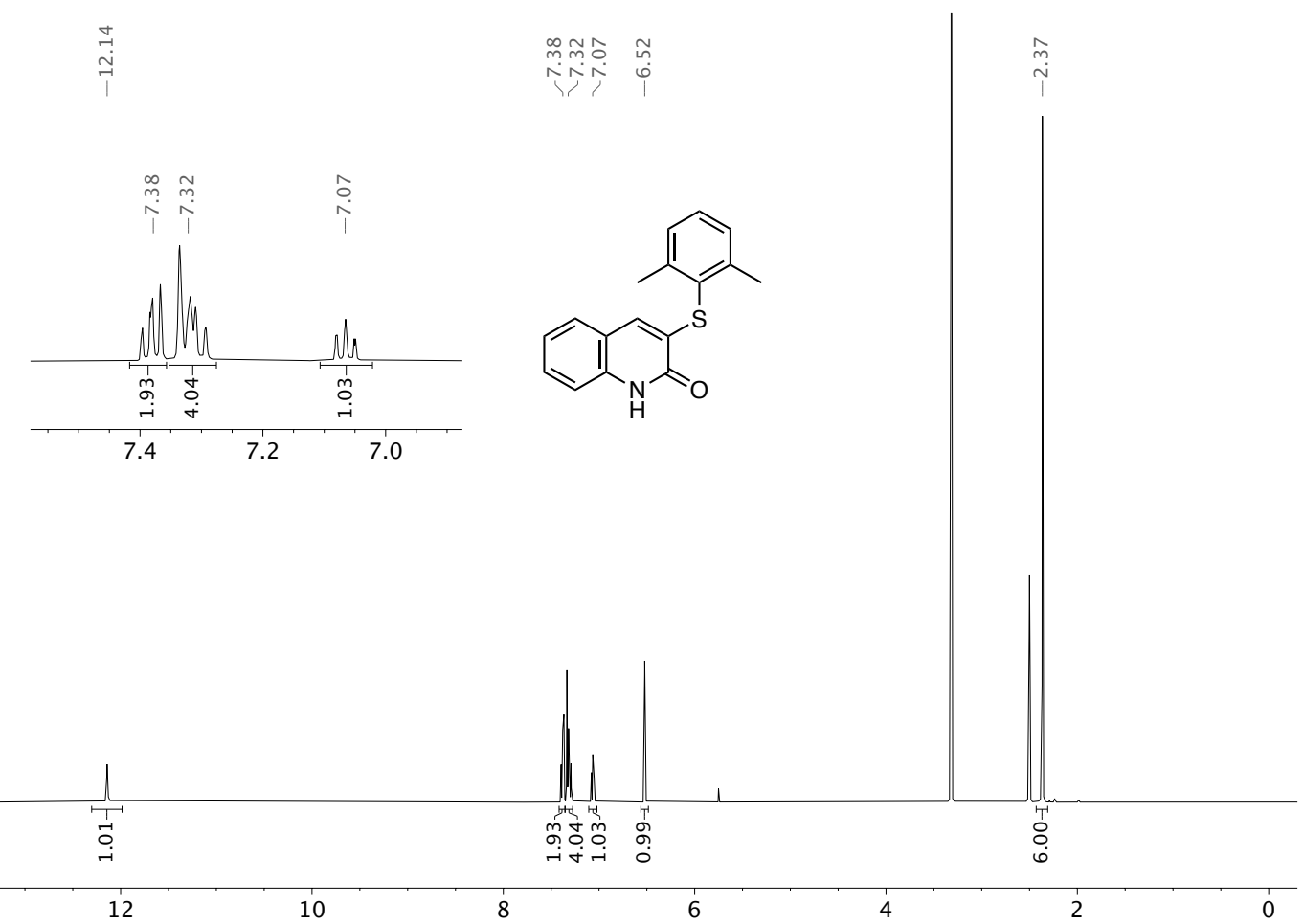

${ }^{13} \mathrm{C}$ NMR $\left(126 \mathrm{MHz}, \mathrm{DMSO}-d_{6}\right)$

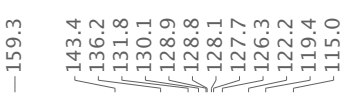

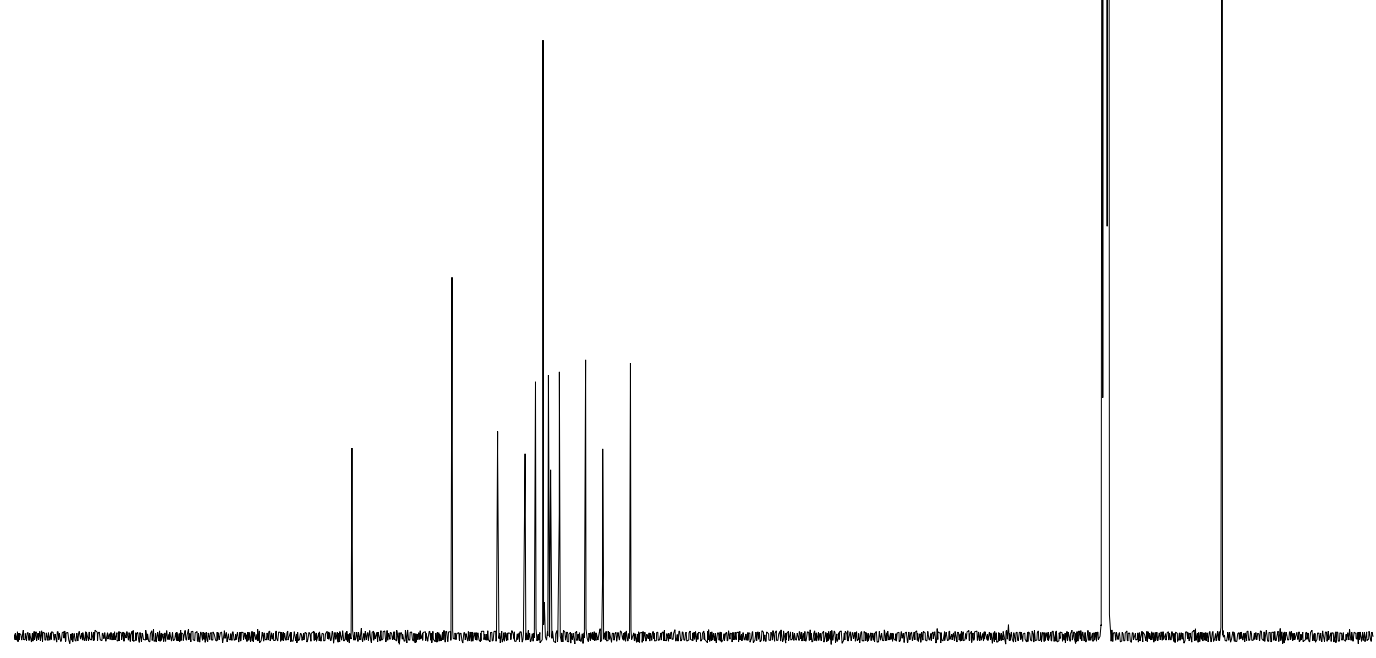

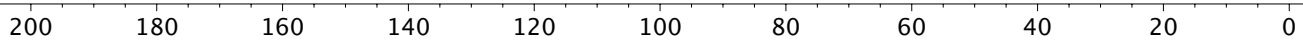


3.1.16. 3-((2,3,5,6-Tetrafluorophenyl)thio)-2-quinolone (7p)

${ }^{1} \mathrm{H} \mathrm{NMR}\left(500 \mathrm{MHz}, \mathrm{CDCl}_{3}\right)$

$$
\stackrel{\infty}{\stackrel{\infty}{\sim}} \underset{\sim}{\rightarrow}
$$

nุํำiñ

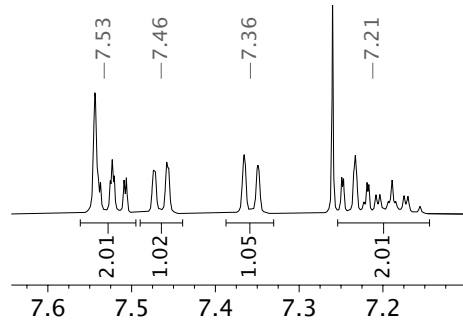<smiles>O=c1[nH]c2ccccc2cc1Sc1c(F)c(F)cc(F)c1F</smiles>

$\begin{array}{lllll}7.6 & 7.5 & 7.4 & 7.3 & 7.2\end{array}$
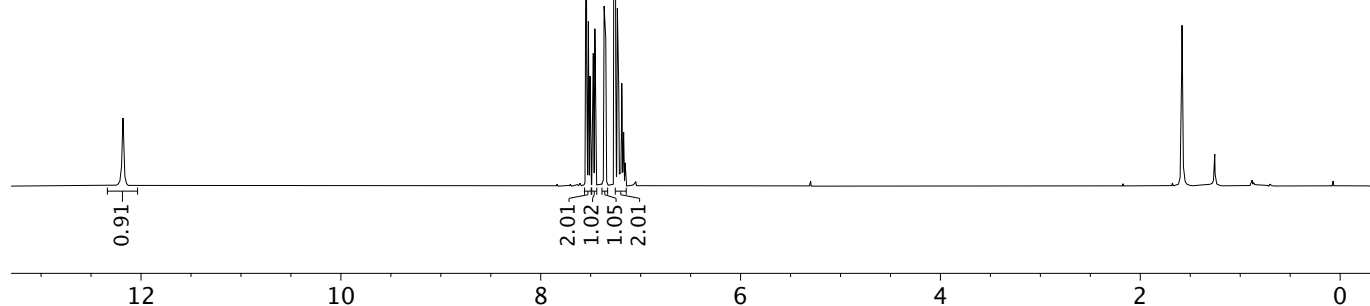

${ }^{13} \mathrm{C} \mathrm{NMR}\left(126 \mathrm{MHz}, \mathrm{CDCl}_{3}\right)$

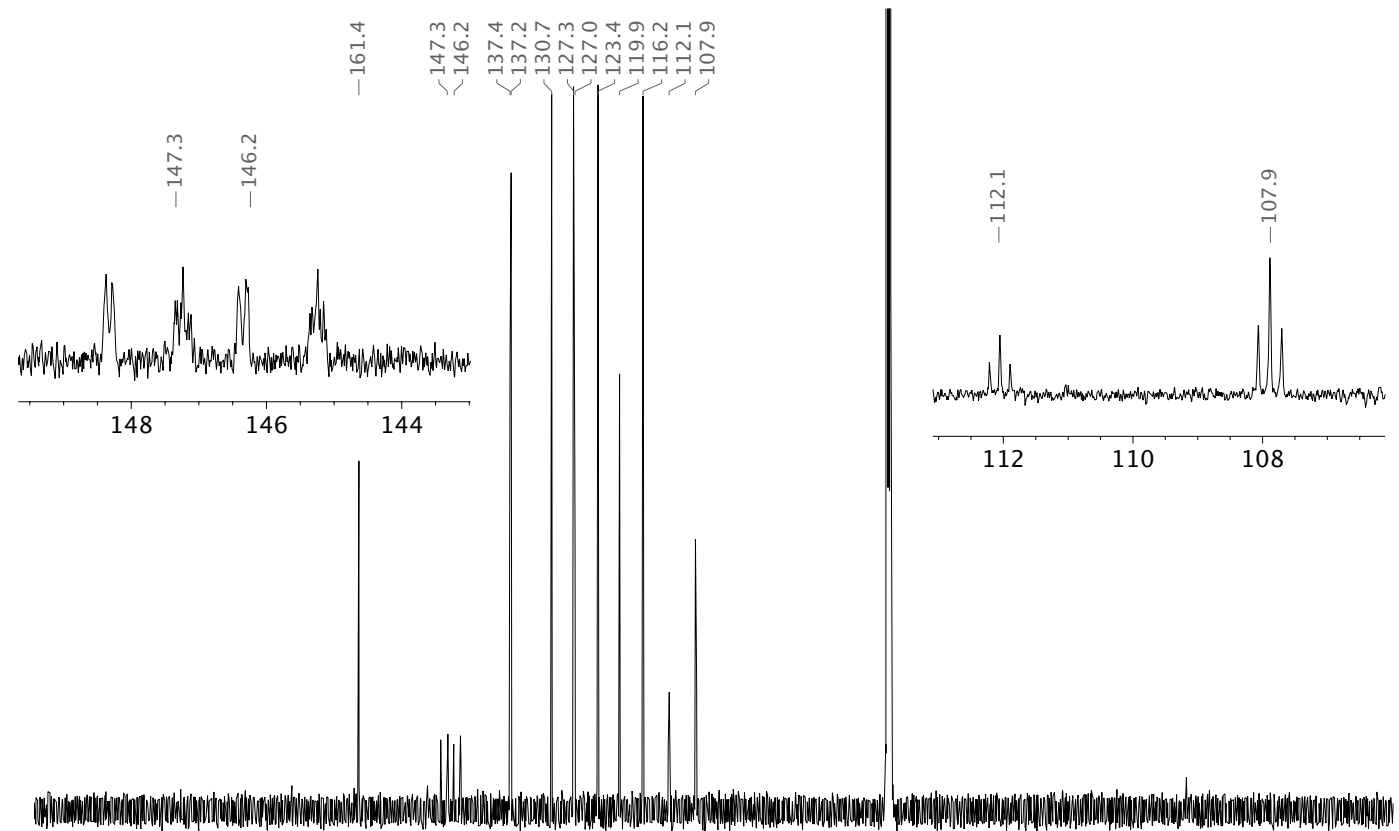

$\begin{array}{lllll}200 & 180 & 160 & 140 & 120\end{array}$ 100 80 60 40 $20 \quad 0$ 
${ }^{19} \mathrm{~F} \mathrm{NMR}\left(376 \mathrm{MHz}, \mathrm{CDCl}_{3}\right.$ )

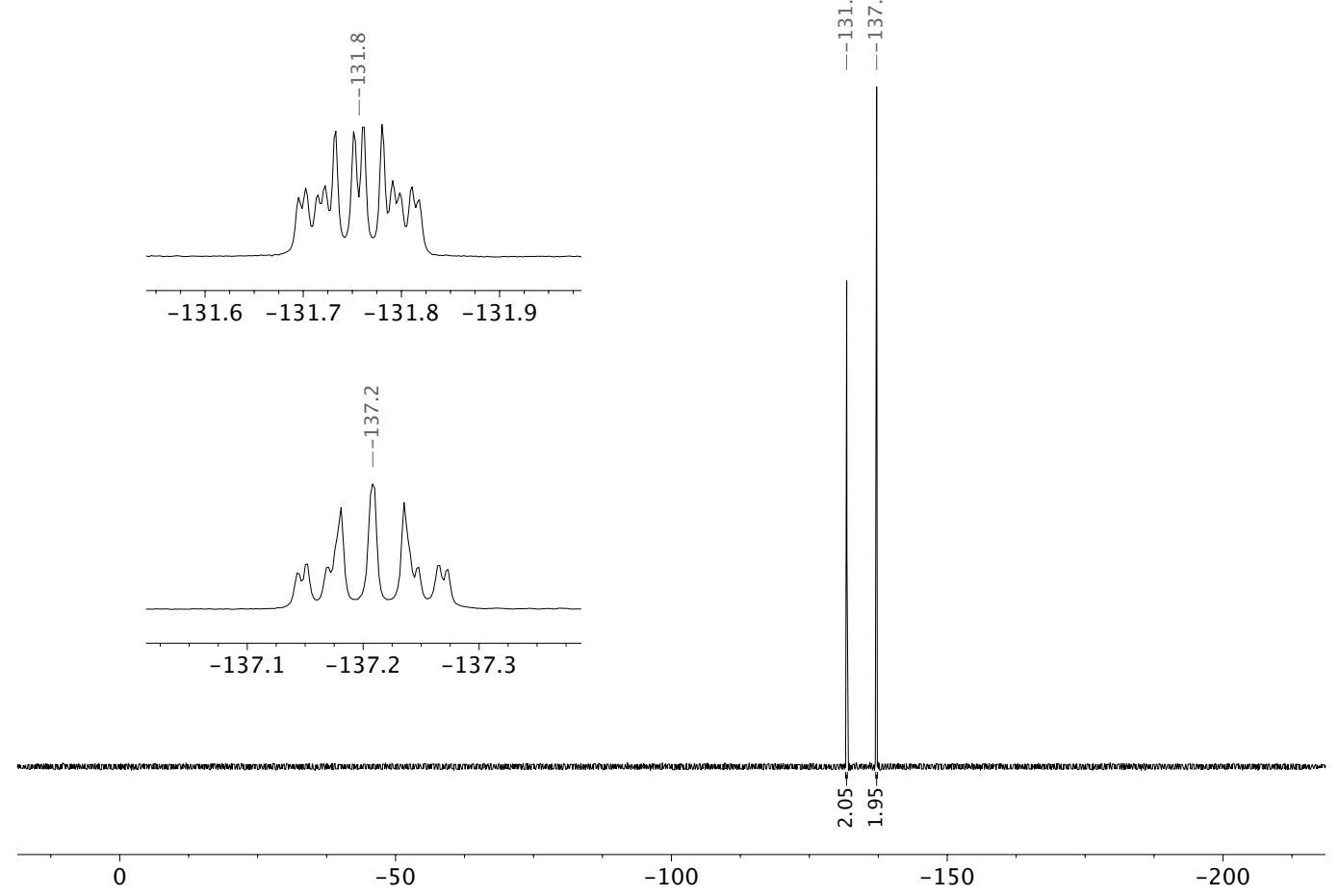


3.1.17. (R)-3-(Phenylsulfinyl)-2-quinolone (8a)

${ }^{1} \mathrm{H}$ NMR (500 MHz, MeOD- $\left.d_{4}\right)$

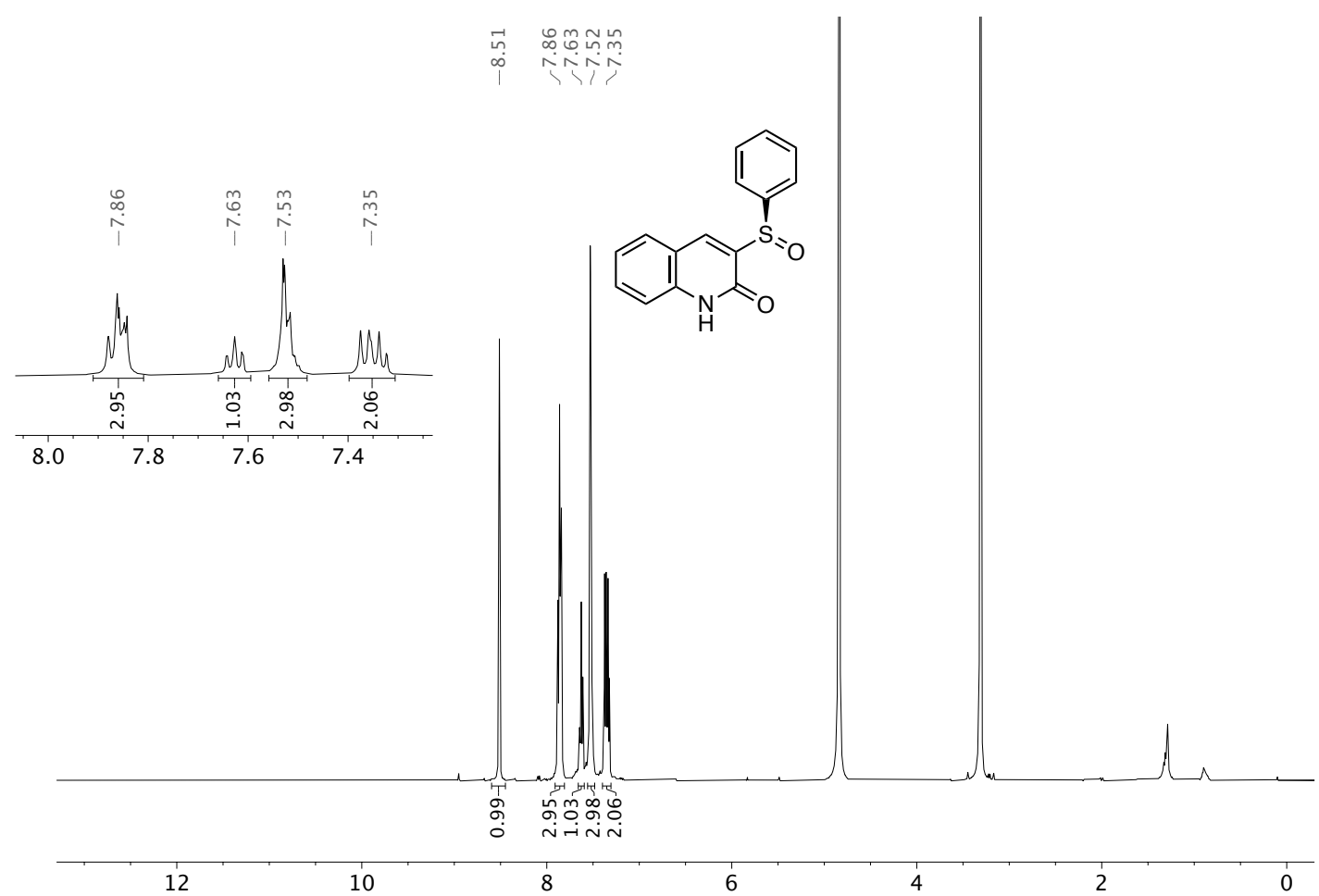

${ }^{13} \mathrm{C}$ NMR (126 MHz, MeOD-d 4 )

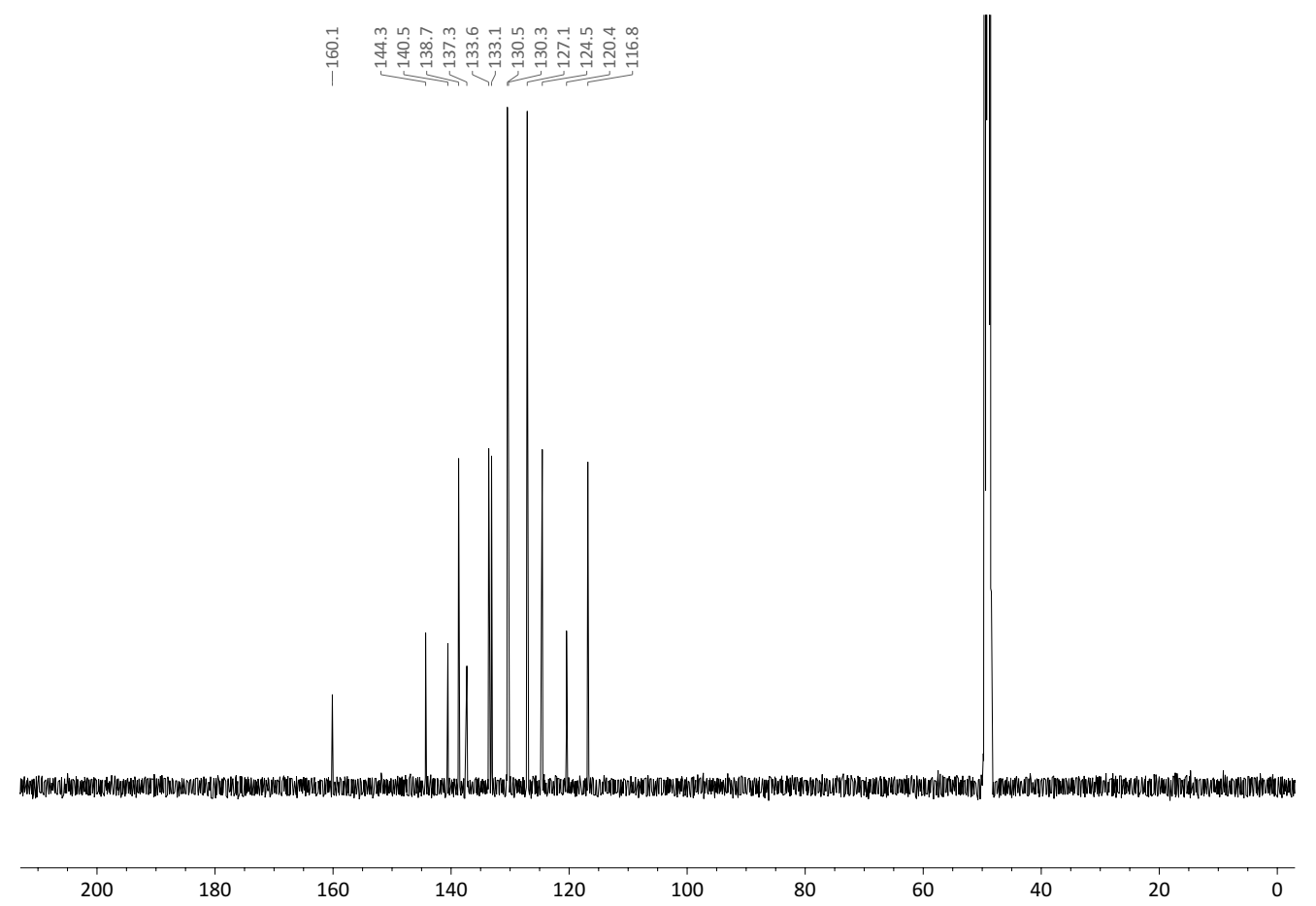


3.1.18. (R)-3-(p-Tolylsulfinyl)-2-quinolone (8b)

${ }^{1} \mathrm{H}$ NMR $\left(500 \mathrm{MHz}, \mathrm{DMSO}-d_{6}\right)$

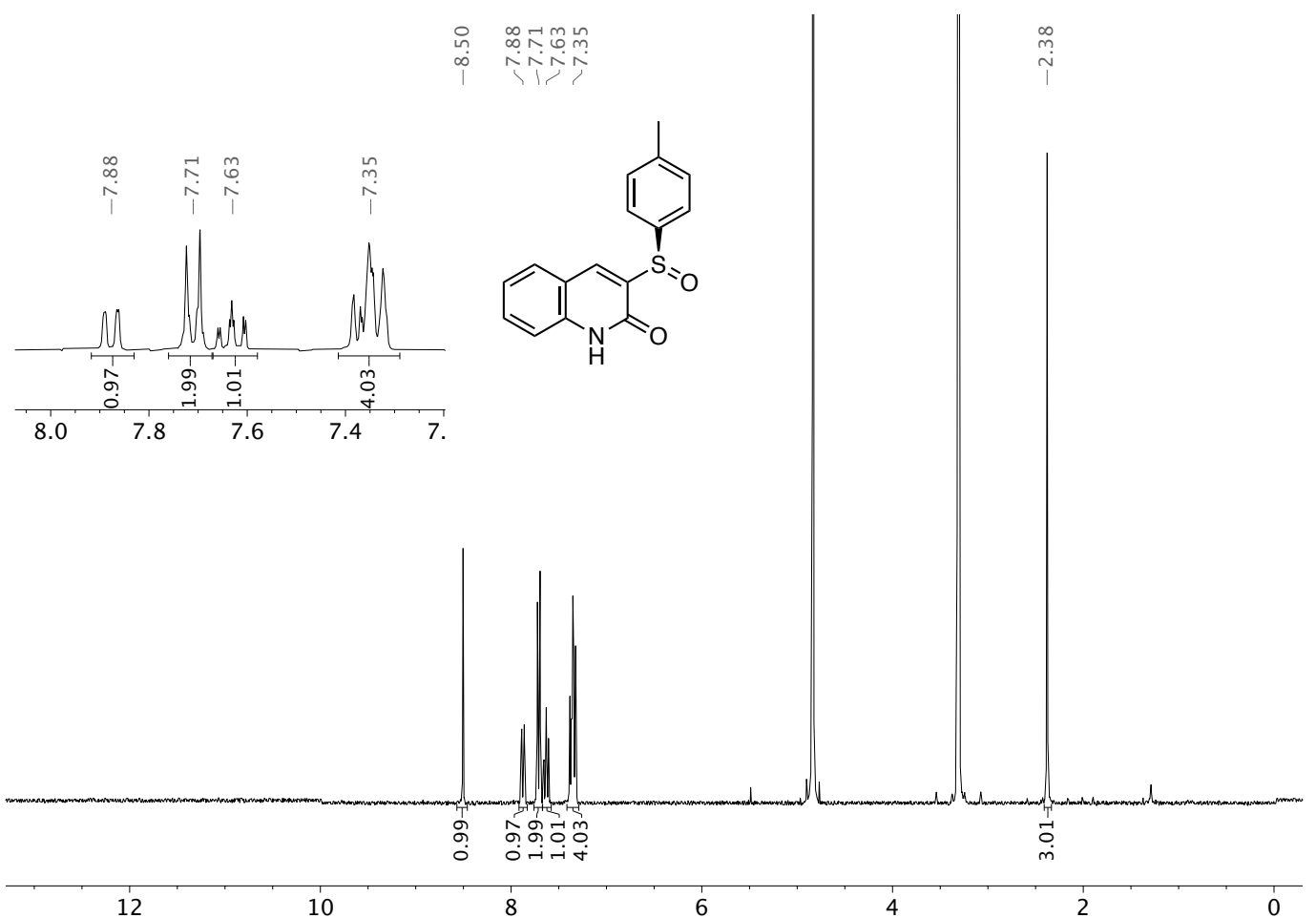

${ }^{13} \mathrm{C}$ NMR (126 MHz, DMSO- $\left.d_{6}\right)$

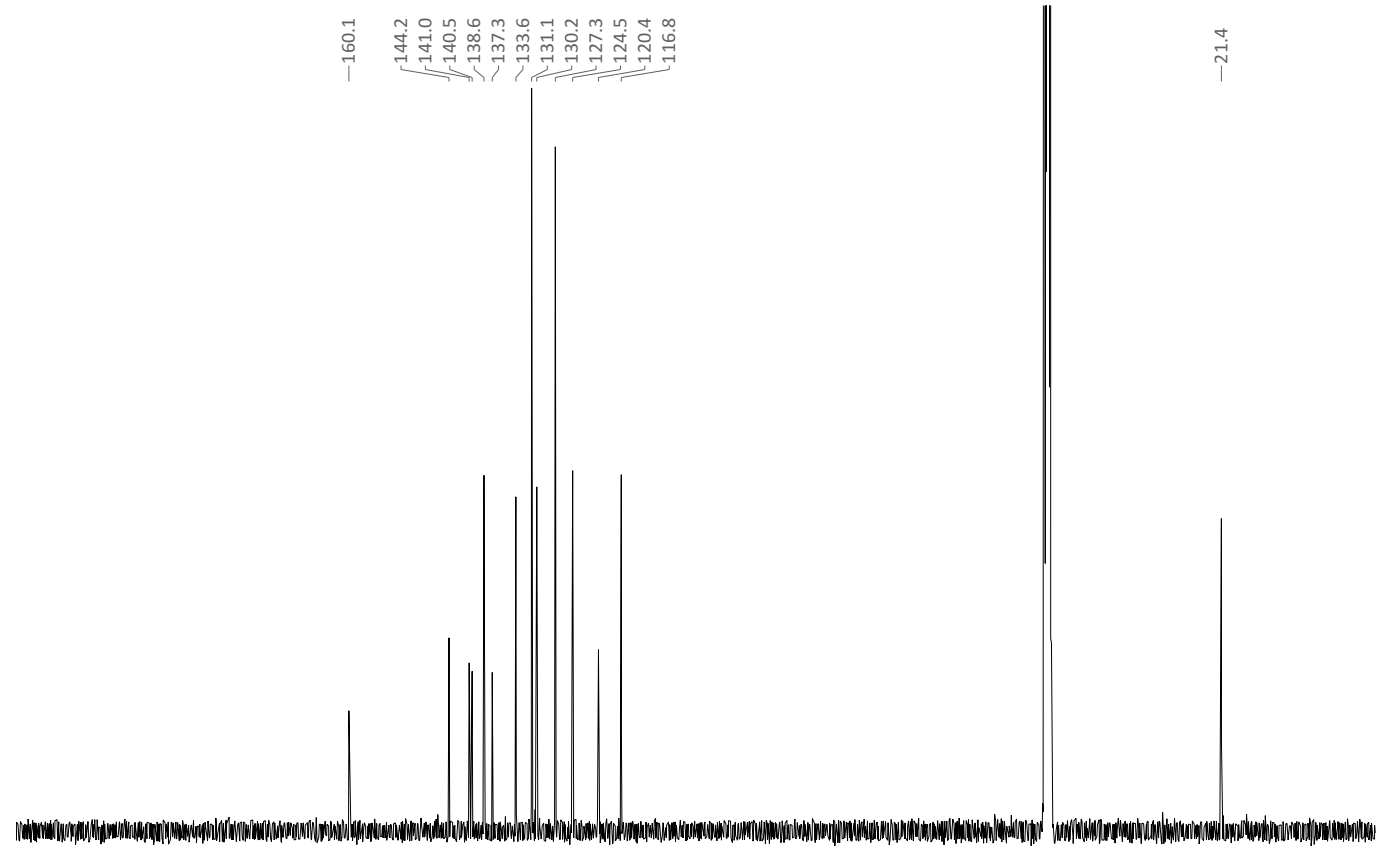

$\begin{array}{lllll}200 & 180 & 160 & 140 & 120\end{array}$

100

80

60

40 T 
3.1.19. (R)-3-((4-Fluorophenyl)sulfinyl)-2-quinolone (8c)

${ }^{1} \mathrm{H}$ NMR $\left(500 \mathrm{MHz}, \mathrm{DMSO}-d_{6}\right)$

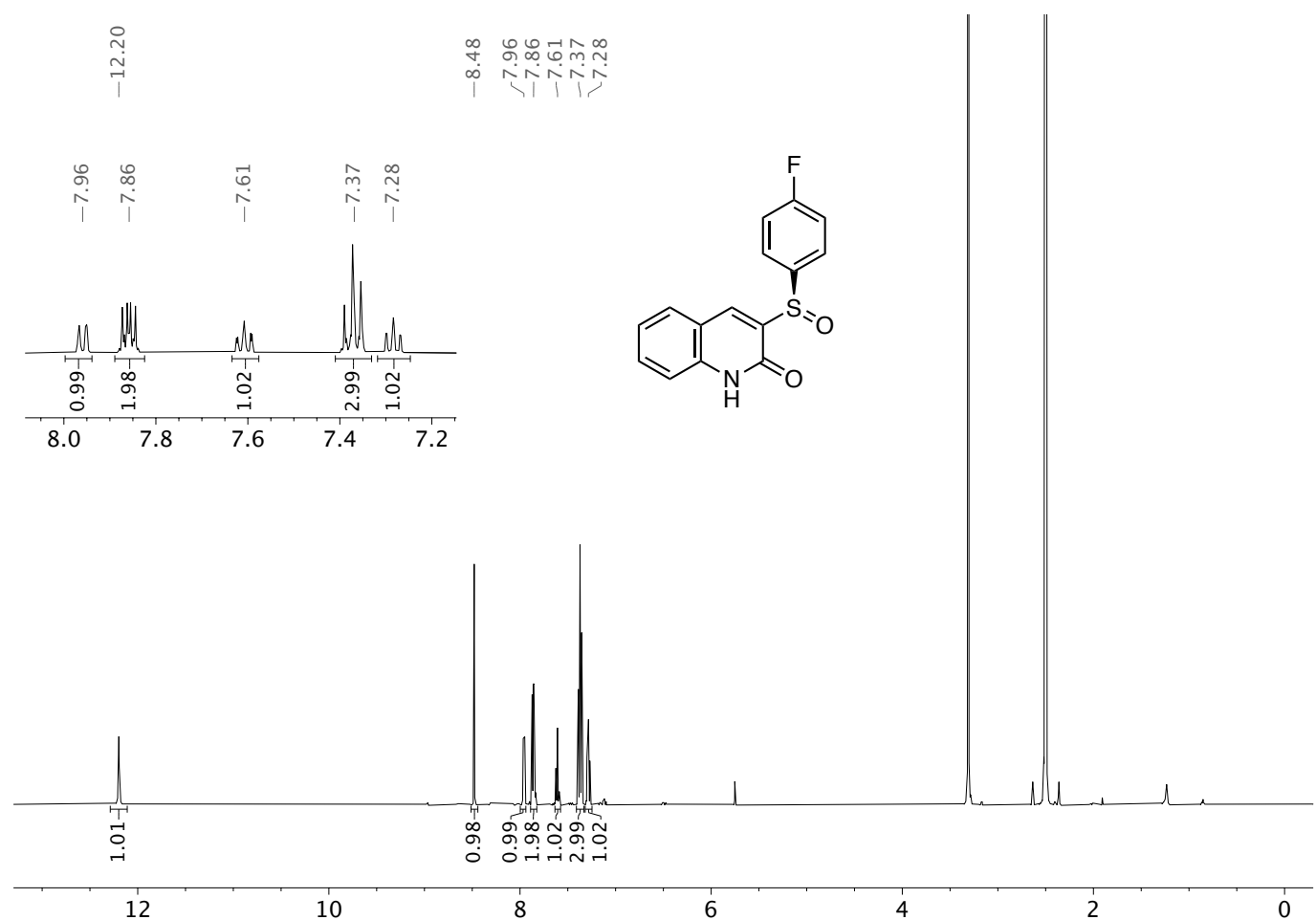

${ }^{13} \mathrm{C}$ NMR $\left(126 \mathrm{MHz}\right.$, DMSO- $\left.d_{6}\right)$

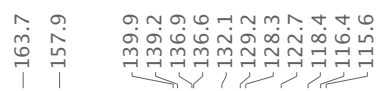

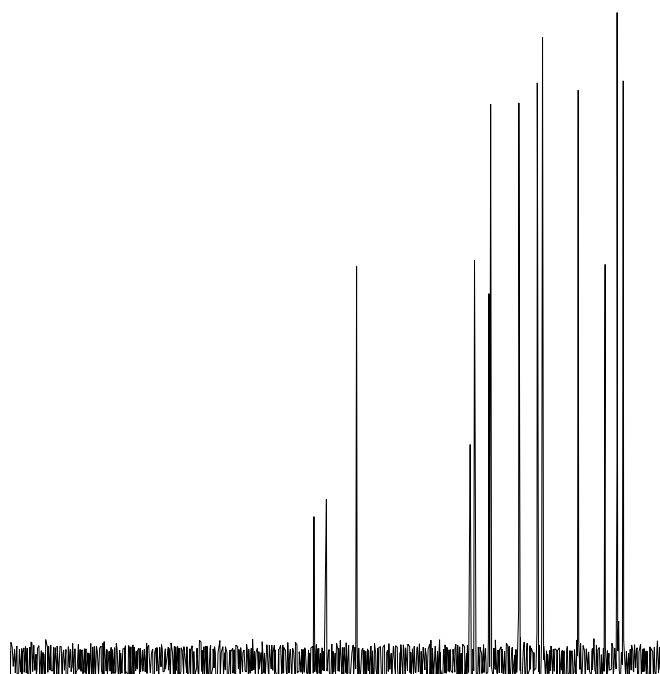

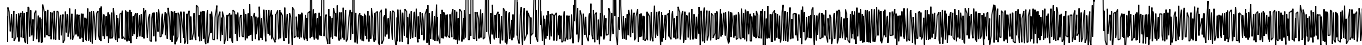

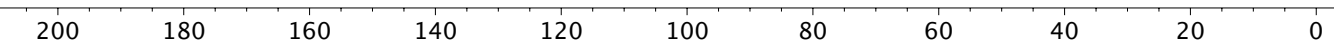


${ }^{19} \mathrm{~F}$ NMR (376 MHz, DMSO- $d_{6}$ )

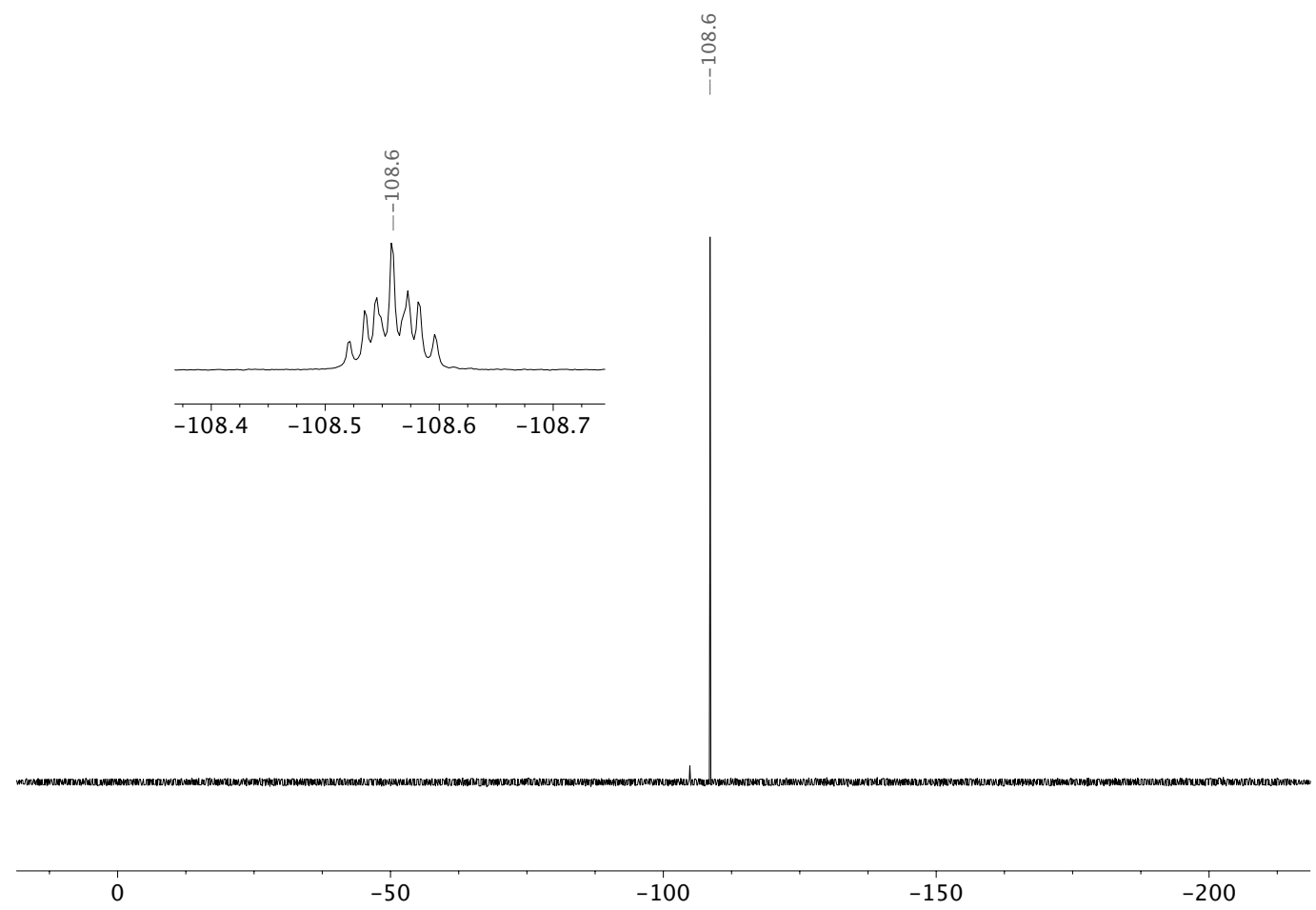


3.1.20. (R)-3-((4-Chlorophenyl)sulfinyl)-2-quinolone (8d)

${ }^{1} \mathrm{H}$ NMR $\left(500 \mathrm{MHz}\right.$, DMSO- $\left.d_{6}\right)$

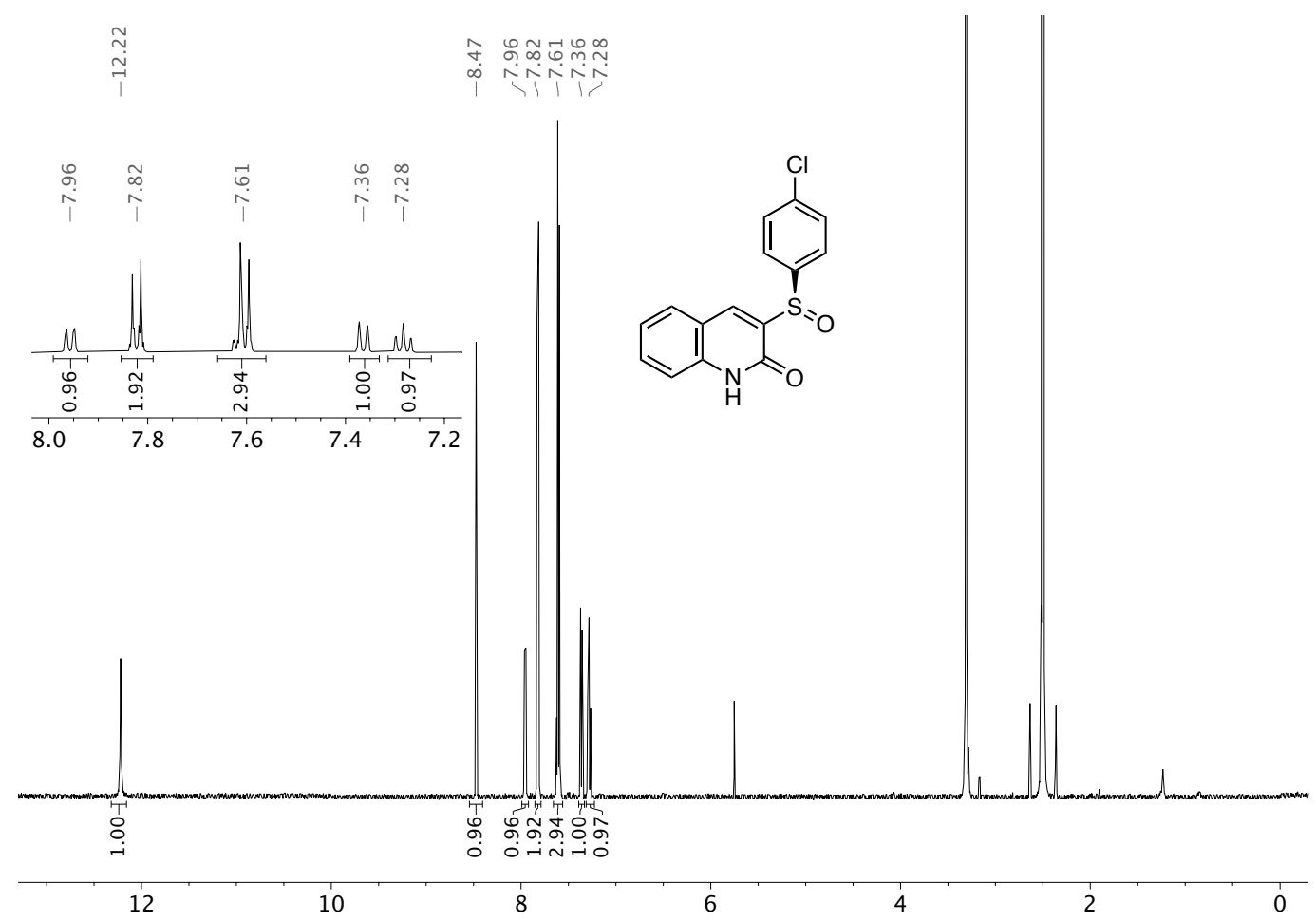

${ }^{13} \mathrm{C}$ NMR $\left(126 \mathrm{MHz}, \mathrm{DMSO}-d_{6}\right)$
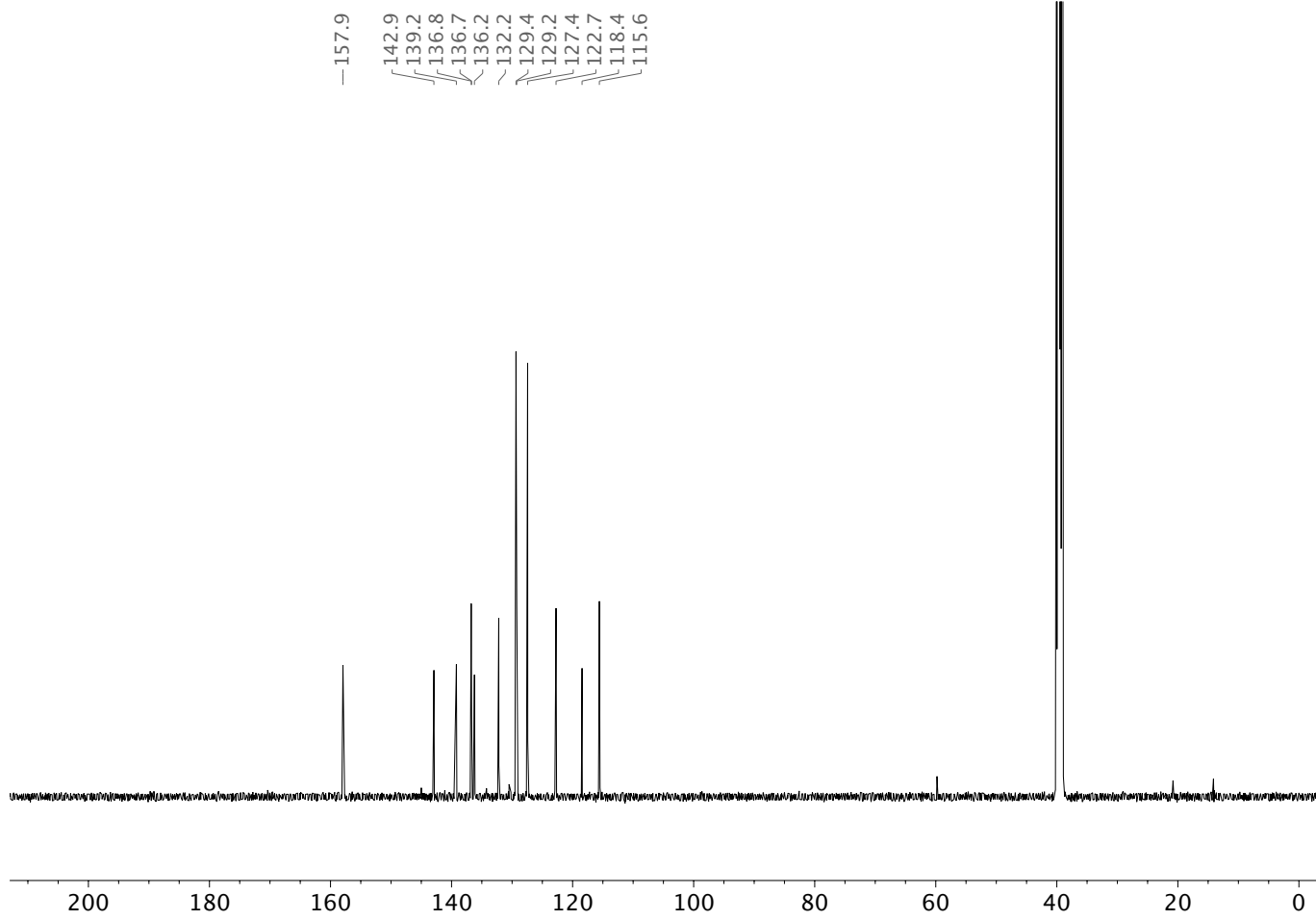
3.1.21. (R)-3-((4-Bromophenyl)sulfinyl)-2-quinolone (8e)

${ }^{1} \mathrm{H}$ NMR $\left(500 \mathrm{MHz}, \mathrm{DMSO}-d_{6}\right)$

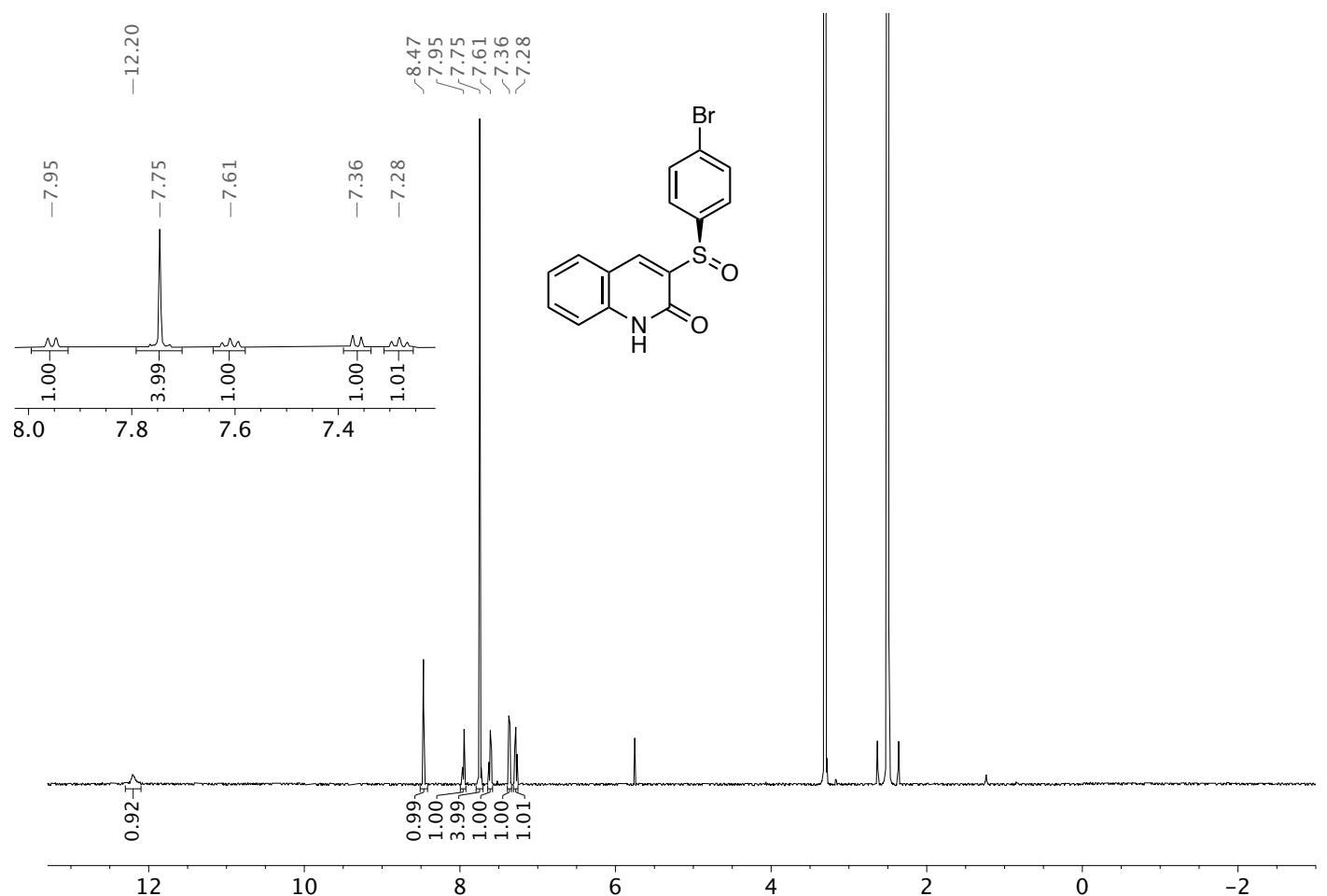

${ }^{13} \mathrm{C}$ NMR $(126 \mathrm{MHz}$, DMSO-d $)$
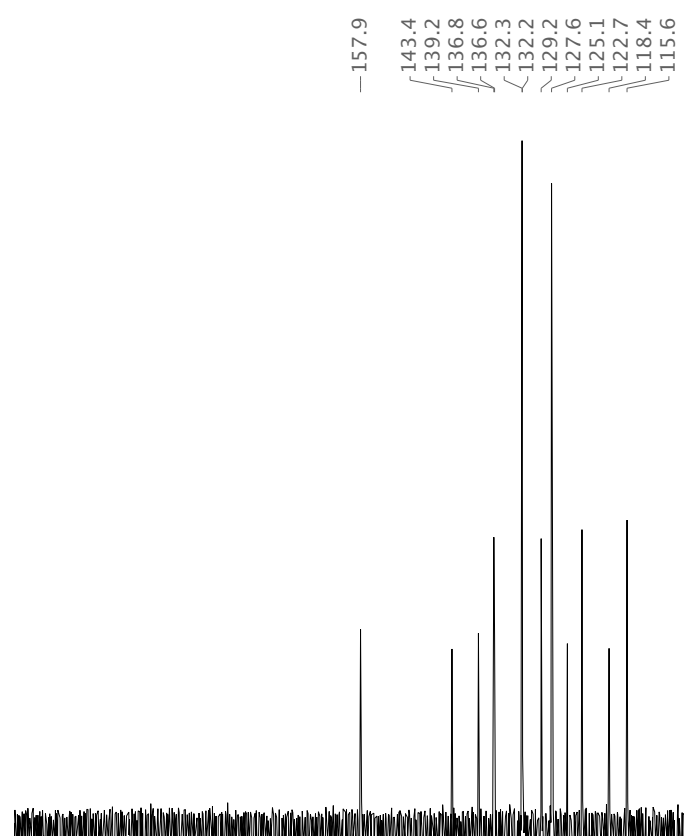

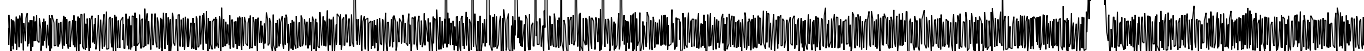


3.1.22. (R)-3-((4-(Trifluoromethyl)phenyl)sulfinyl)-2-quinolone (8f)

${ }^{1} \mathrm{H}$ NMR $\left(500 \mathrm{MHz}, \mathrm{DMSO}-d_{6}\right)$

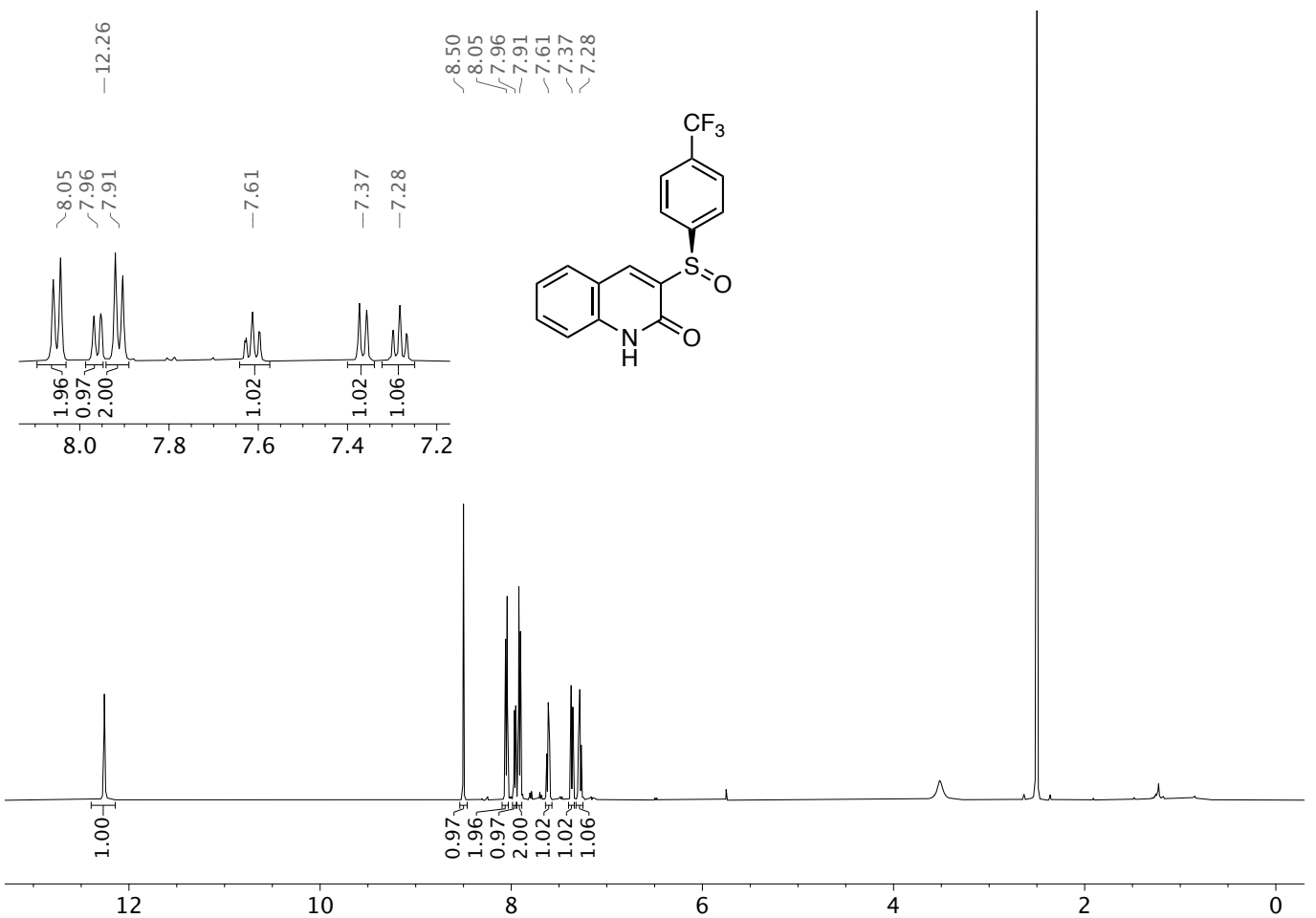

${ }^{13} \mathrm{C}$ NMR $\left(126 \mathrm{MHz}\right.$, DMSO- $\left.d_{6}\right)$

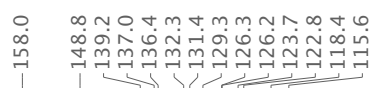

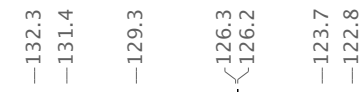
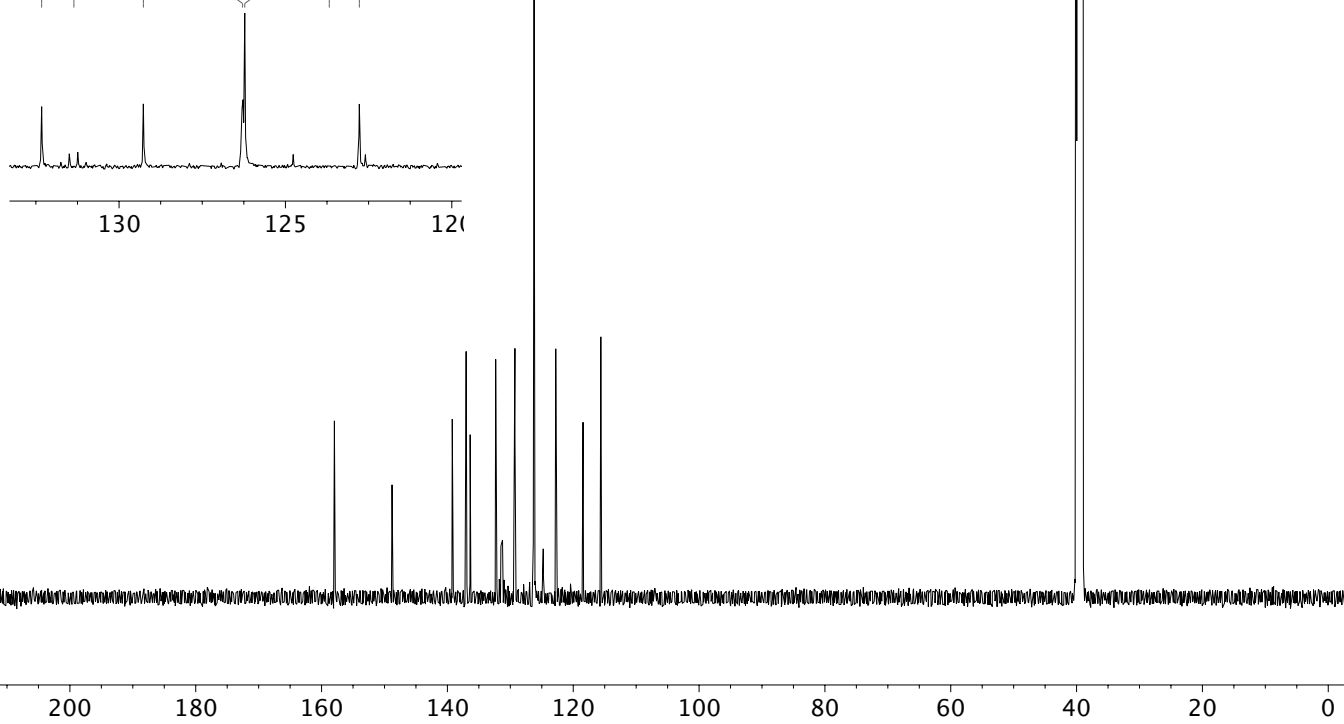
${ }^{19} \mathrm{~F}$ NMR (376 MHz, DMSO- $d_{6}$ )

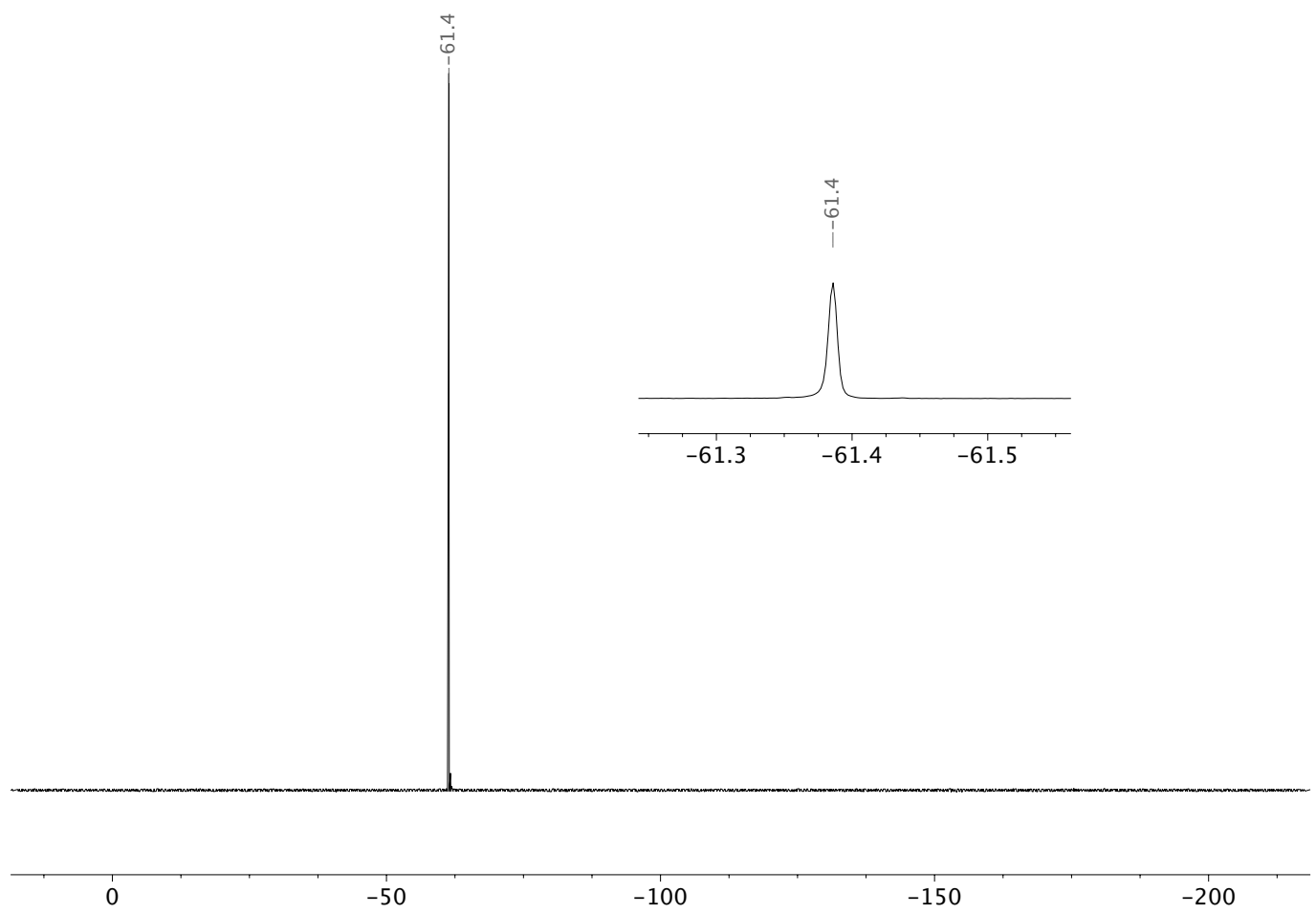


3.1.23. (R)-6-Methyl-3-(phenylsulfinyl)-2-quinolone (8g)

${ }^{1} \mathrm{H}$ NMR $\left(500 \mathrm{MHz}\right.$, DMSO- $\left.d_{6}\right)$

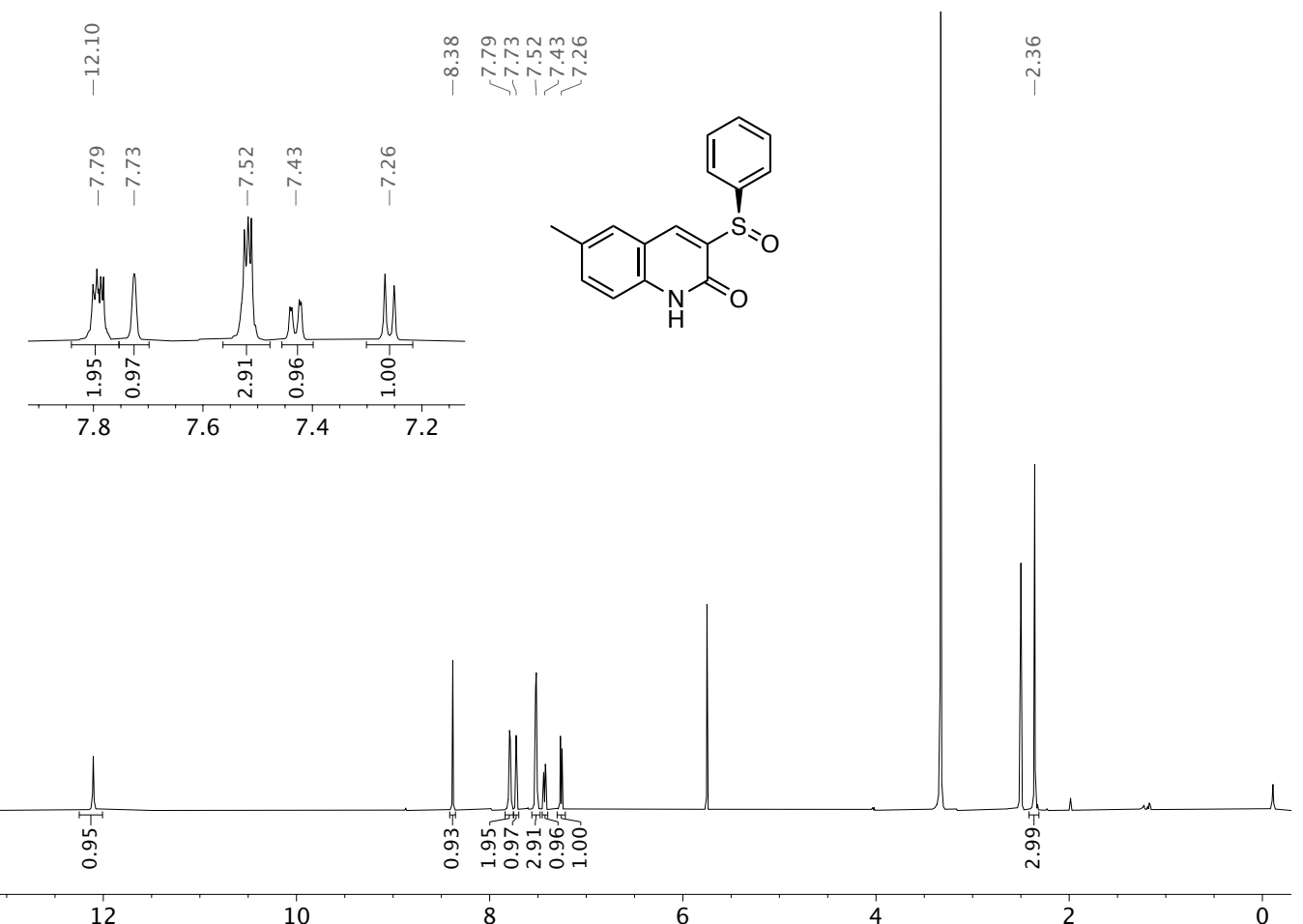

${ }^{13} \mathrm{C}$ NMR $\left(126 \mathrm{MHz}, \mathrm{DMSO}-d_{6}\right)$

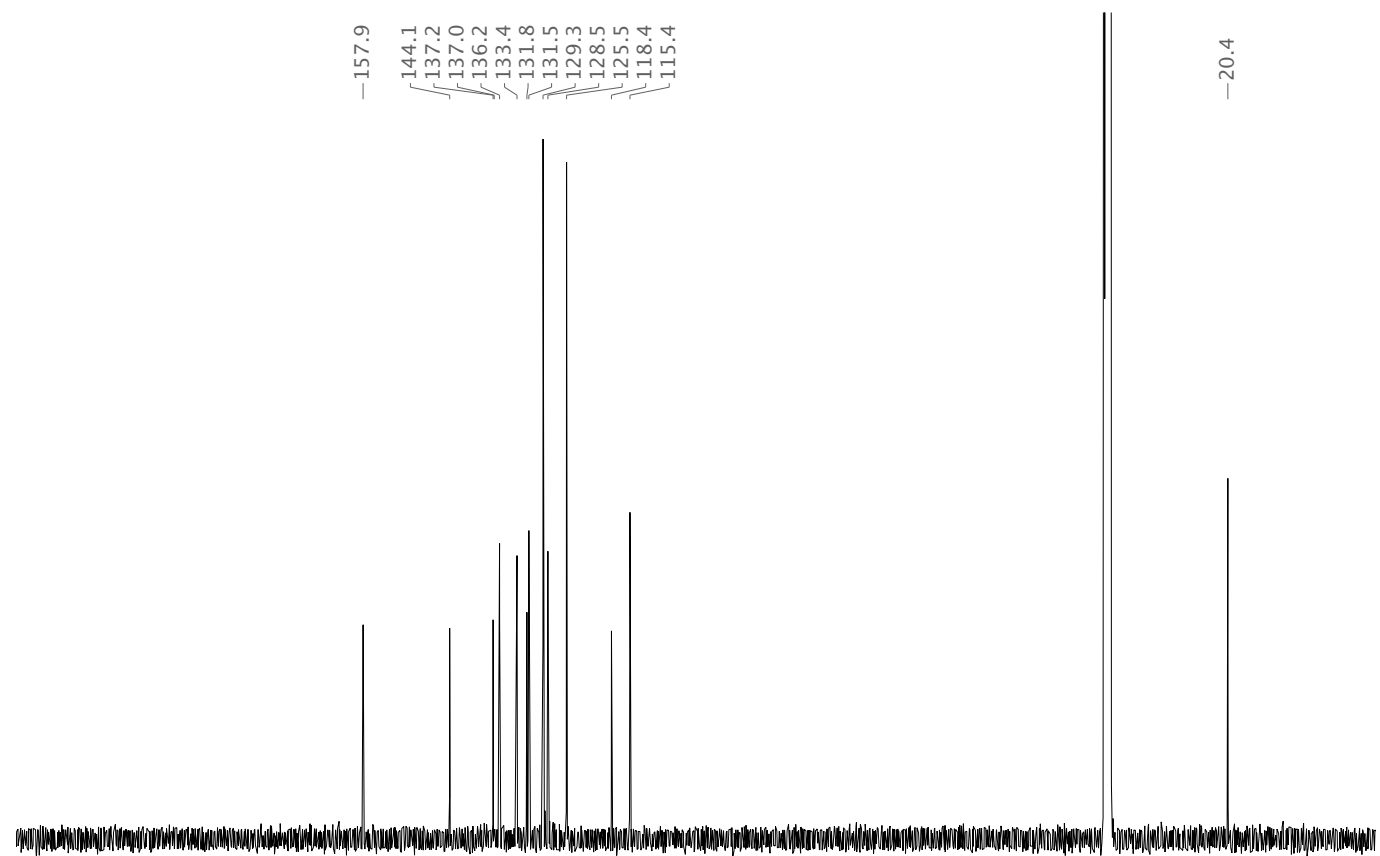

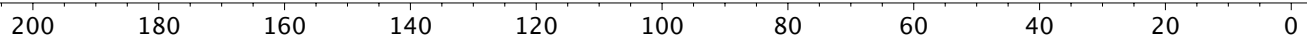


3.1.24. (R)-7-Methyl-3-(phenylsulfinyl)-2-quinolone (8h)

${ }^{1} \mathrm{H}$ NMR $\left(500 \mathrm{MHz}, \mathrm{DMSO}-d_{6}\right)$

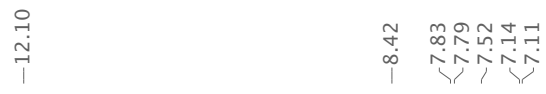

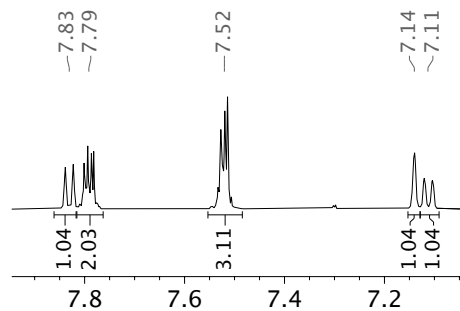<smiles>Cc1ccc2cc(S(=O)(=O)c3ccccc3)c(=O)[nH]c2c1</smiles>

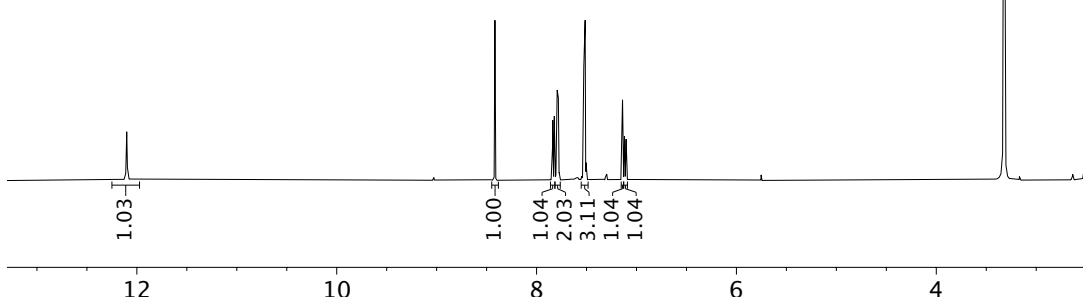

\section{울}

${ }^{13} \mathrm{C}$ NMR $\left(126 \mathrm{MHz}, \mathrm{DMSO}-d_{6}\right)$

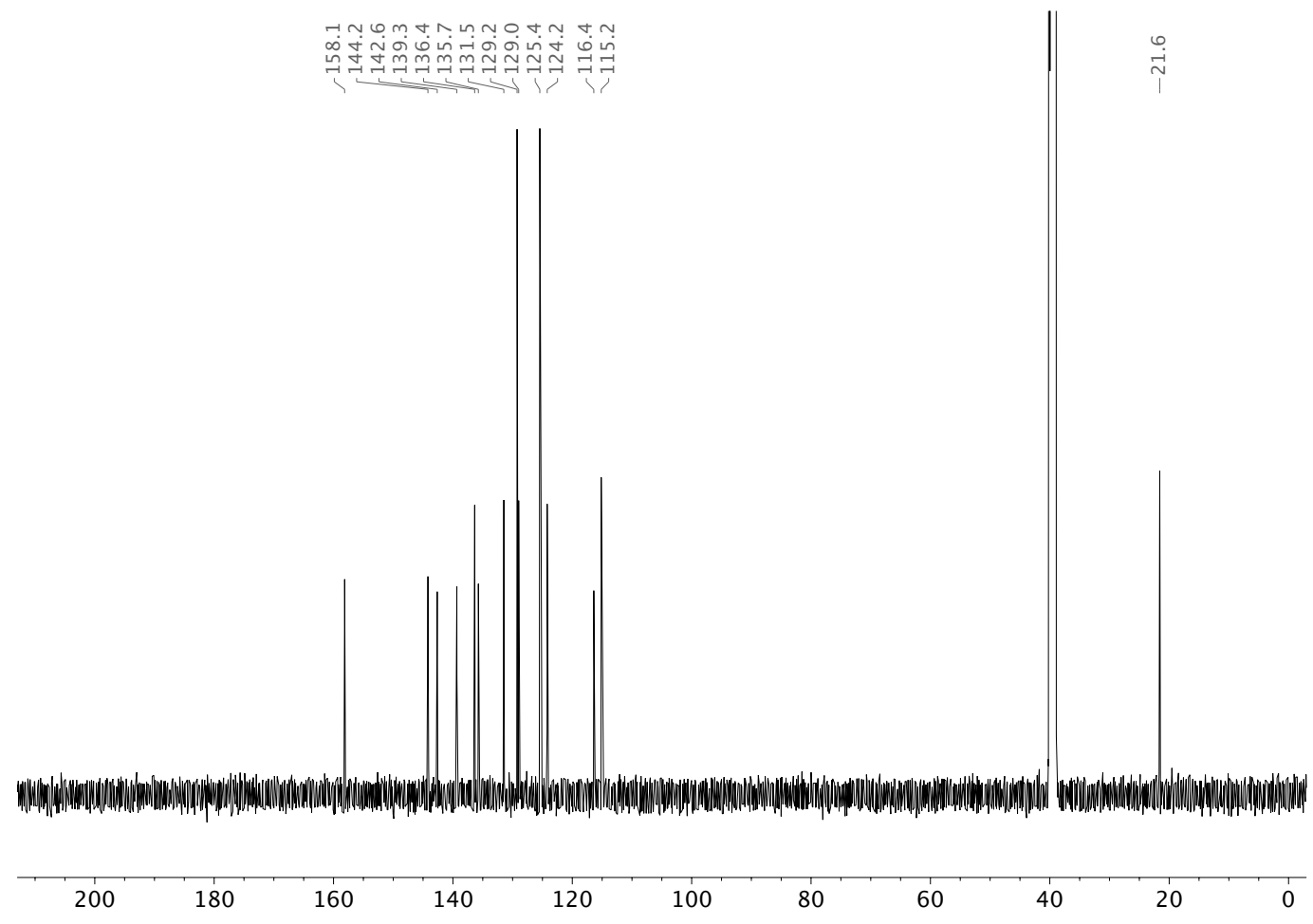


3.1.25. (R)-3-((Naphthalen-2-ylsulfinyl)-2-quinolone (8i)

${ }^{1} \mathrm{H}$ NMR (500 MHz, DMSO- $\left.d_{6}\right)$
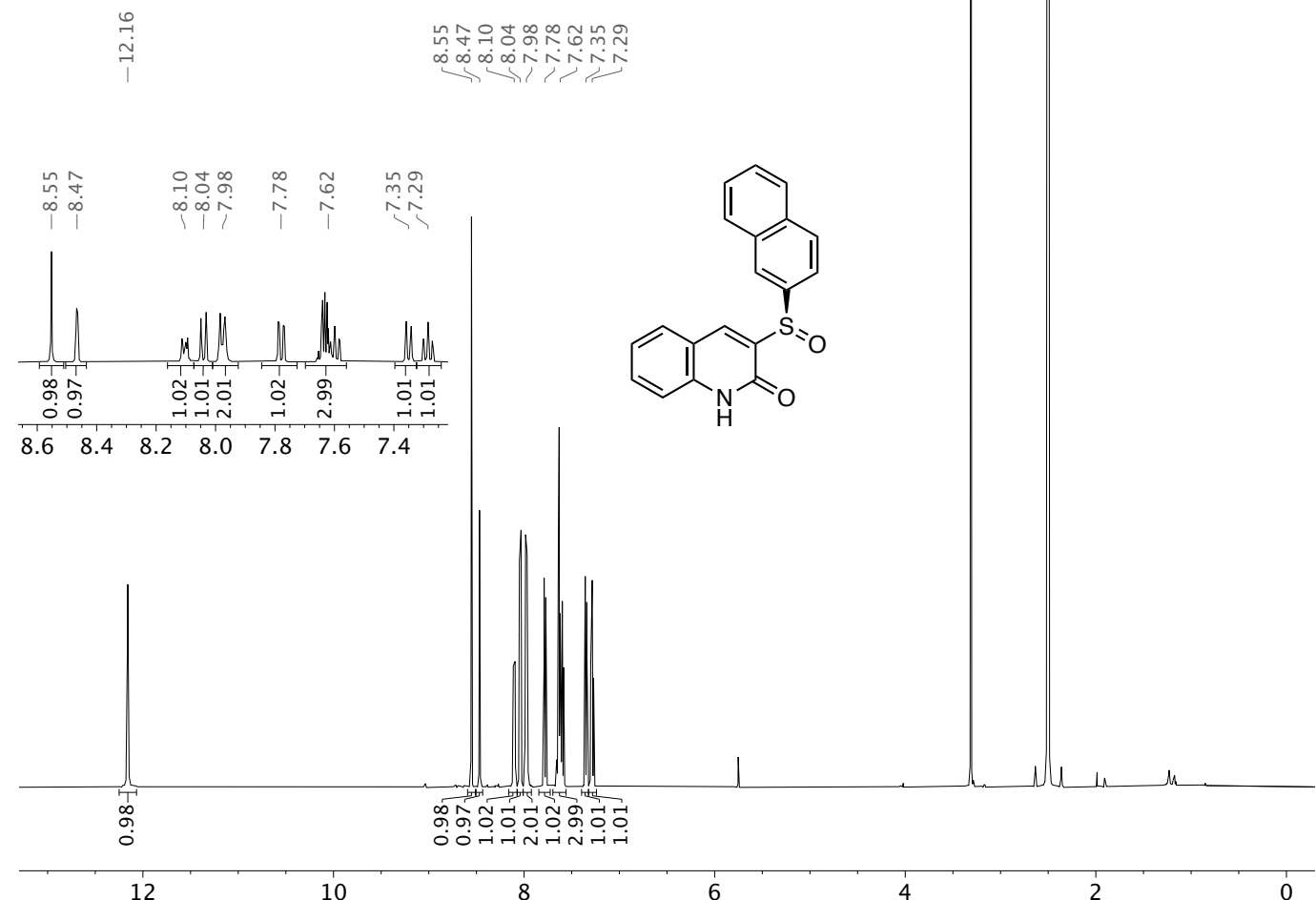

${ }^{13} \mathrm{C}$ NMR (126 MHz, DMSO-d 6 )

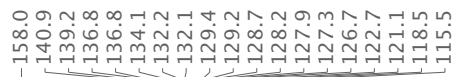

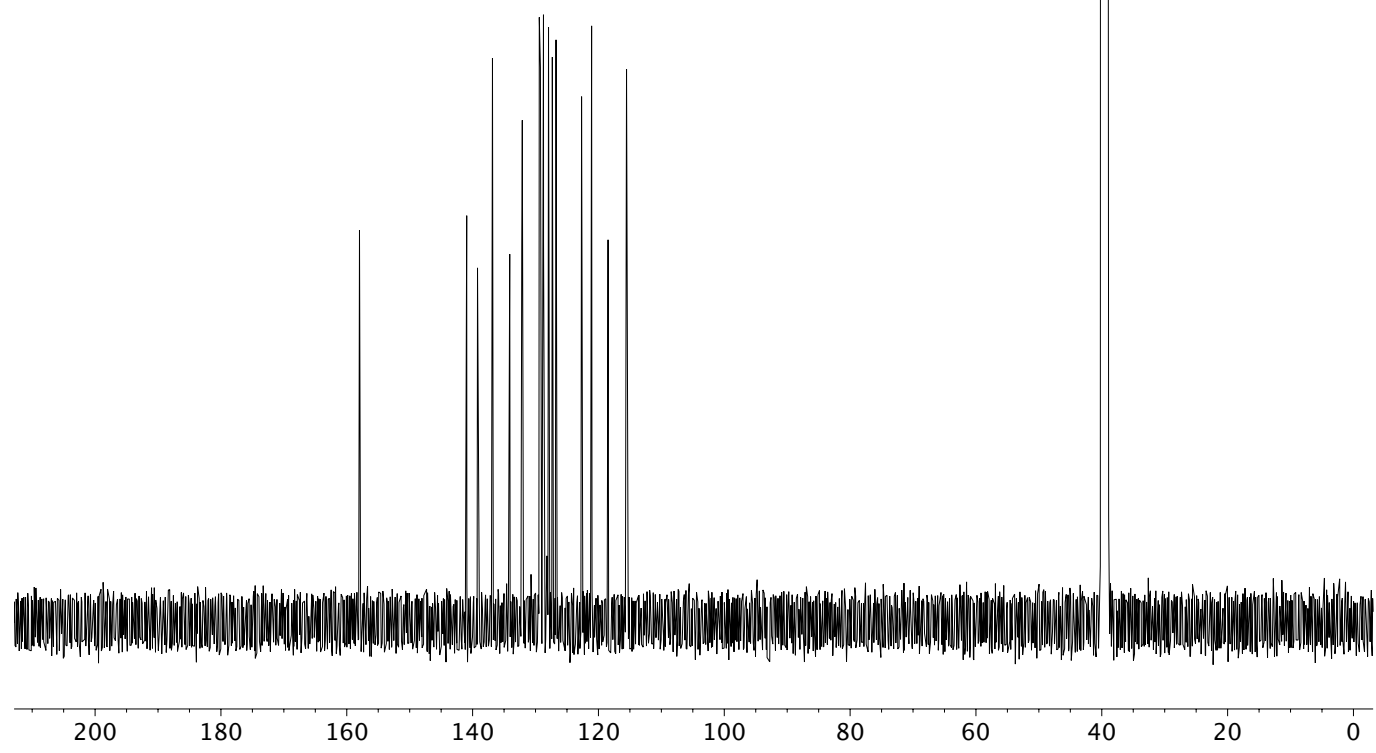


3.1.26. (R)-3-(m-Tolylsulfinyl)-2-quinolone (8j)

${ }^{1} \mathrm{H}$ NMR (500 MHz, DMSO- $\left.d_{6}\right)$

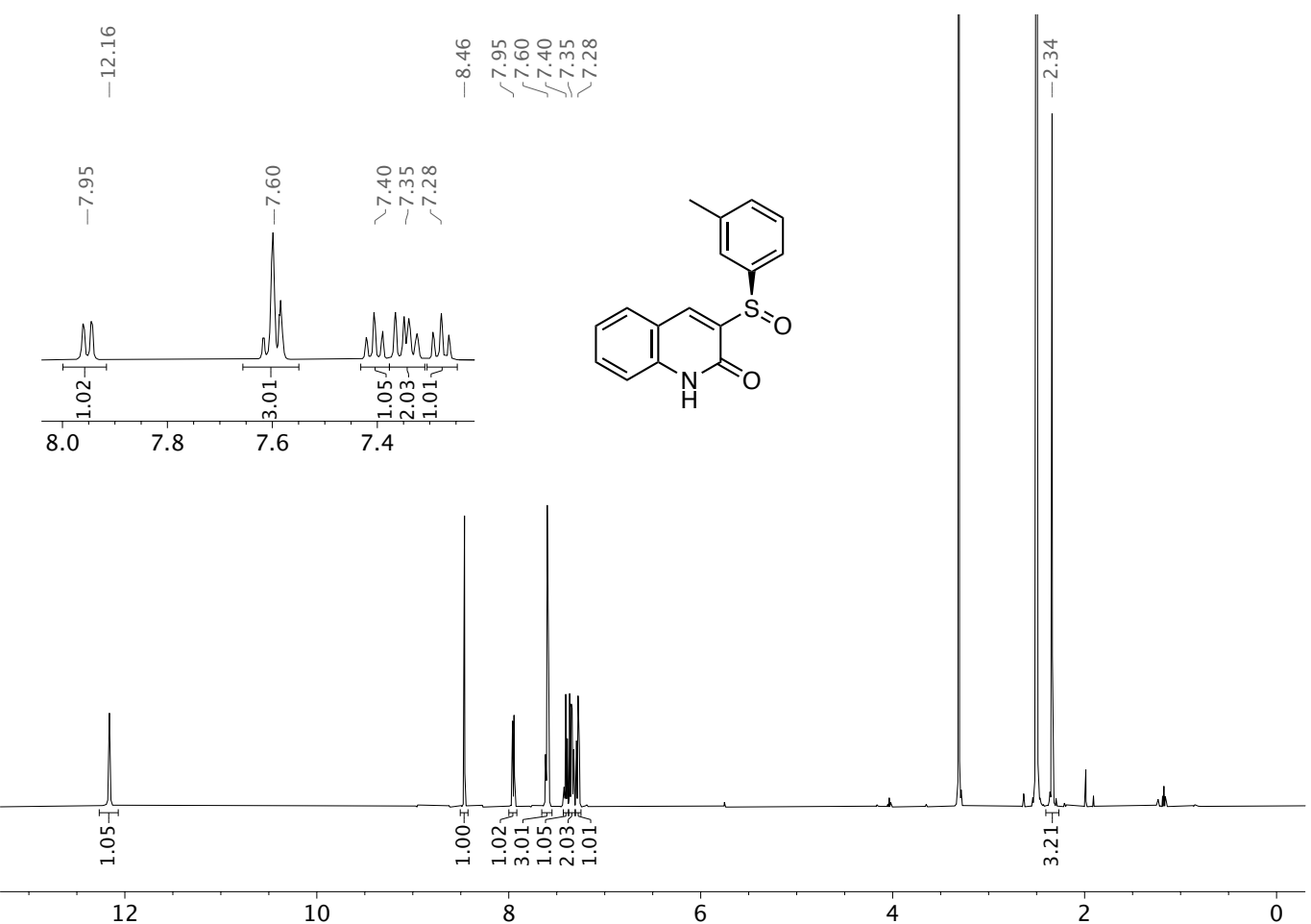

${ }^{13} \mathrm{C}$ NMR (126 MHz, DMSO- $\left.d_{6}\right)$

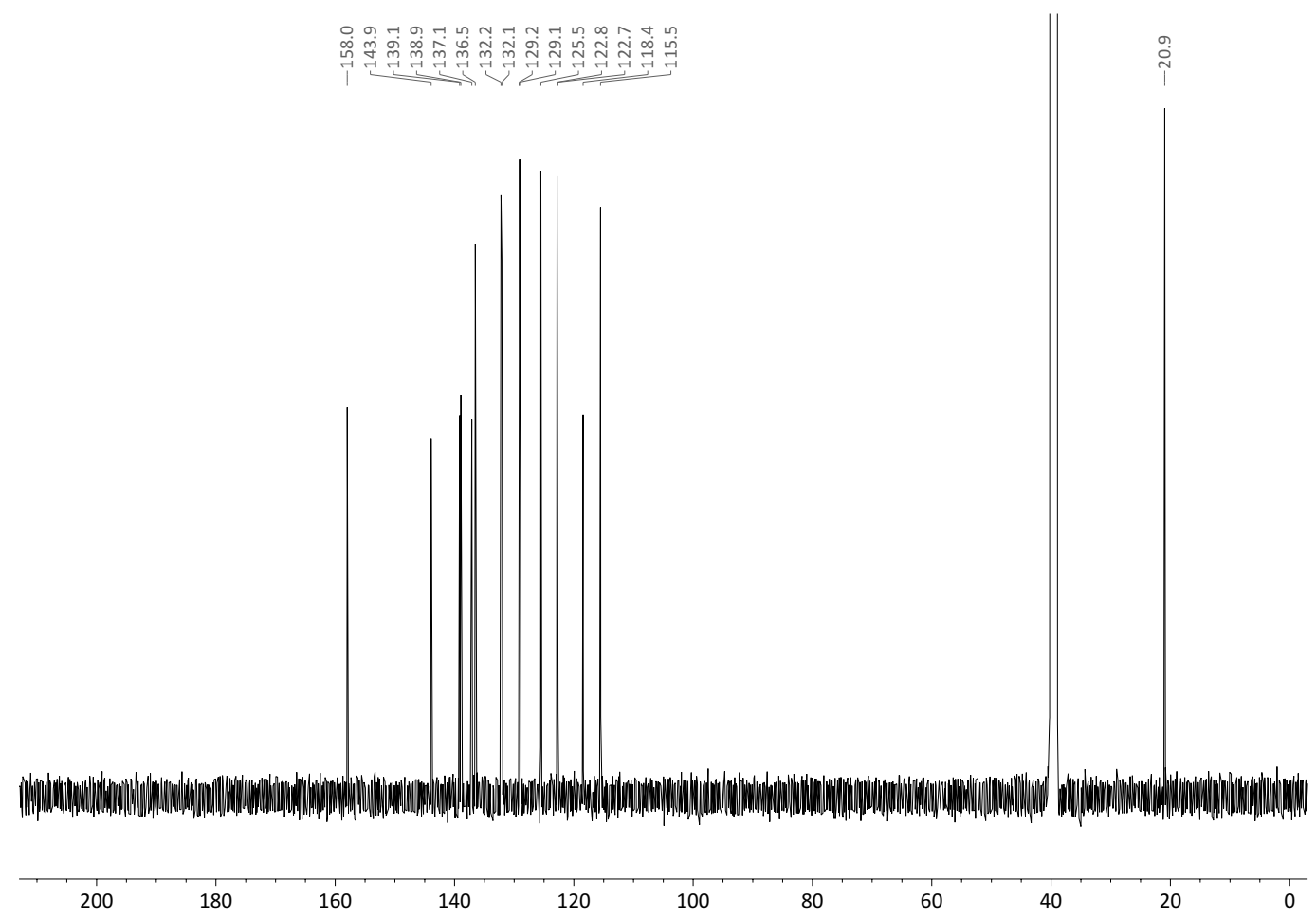


3.1.27. (R)-3-((3-Fluorophenyl)sulfinyl)-2-quinolone (8k)

${ }^{1} \mathrm{H}$ NMR $\left(500 \mathrm{MHz}\right.$, DMSO- $\left.d_{6}\right)$

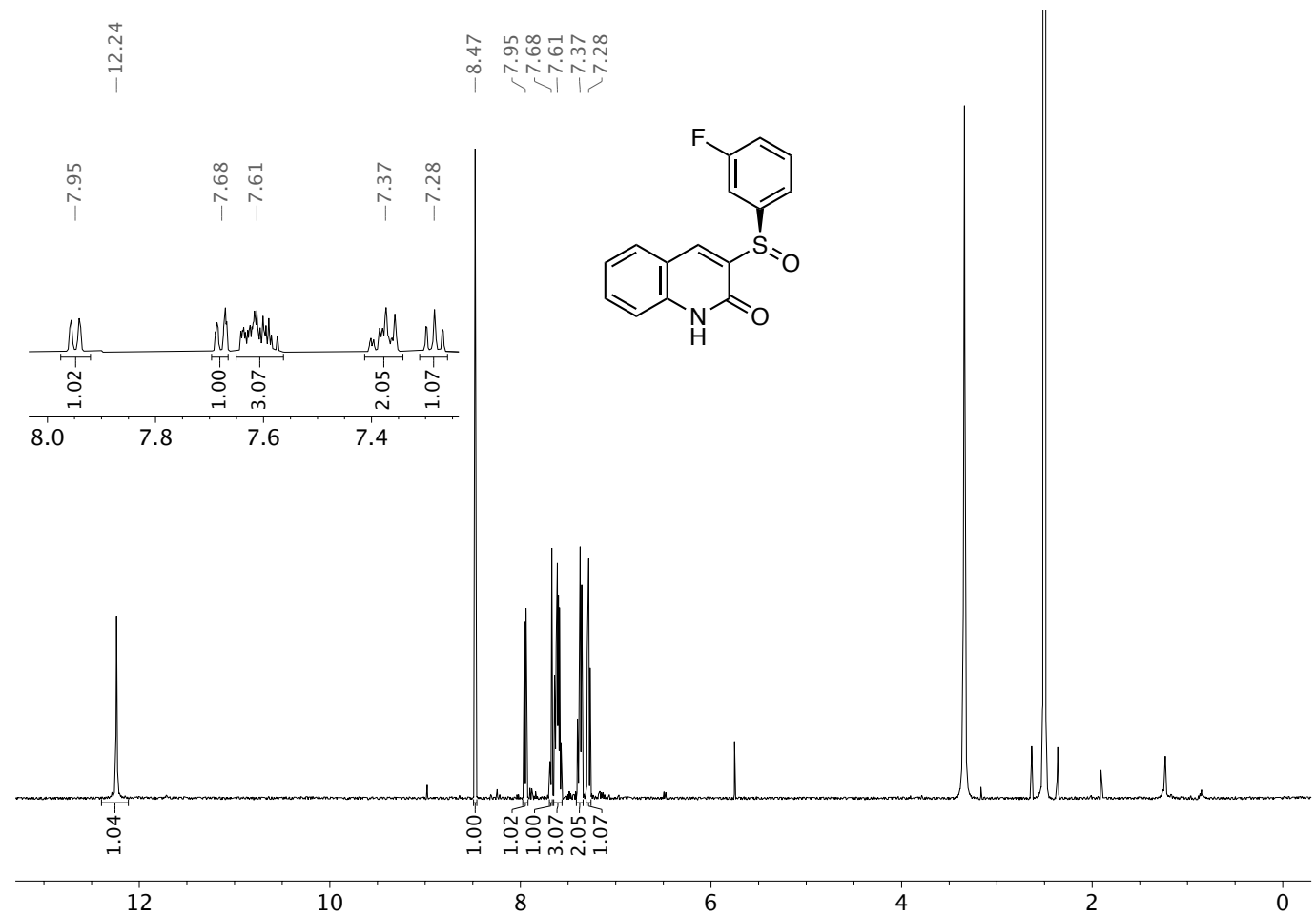

${ }^{13} \mathrm{C}$ NMR $\left(126 \mathrm{MHz}, \mathrm{DMSO}-d_{6}\right)$

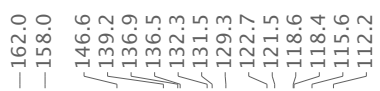

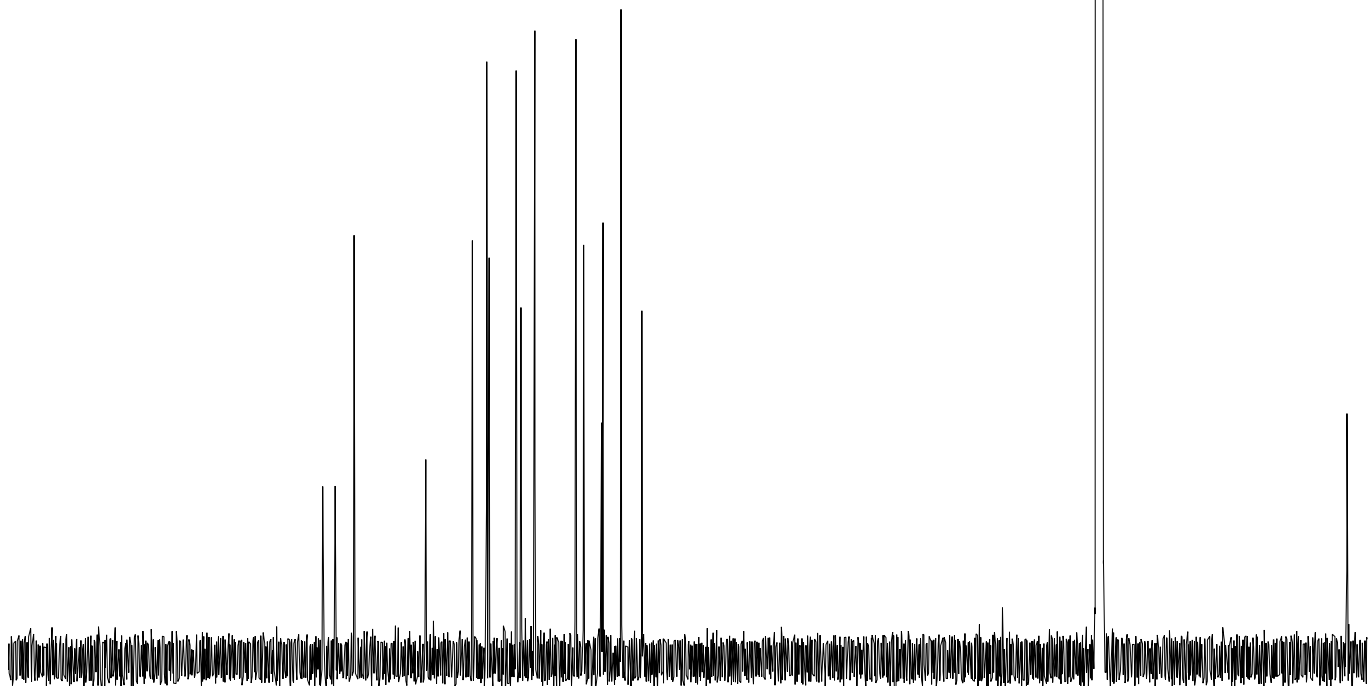

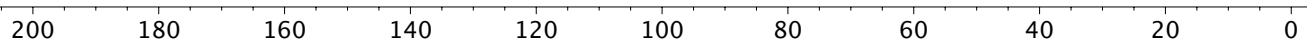


${ }^{19}$ F NMR (376 MHz, DMSO- $\left.d_{6}\right)$

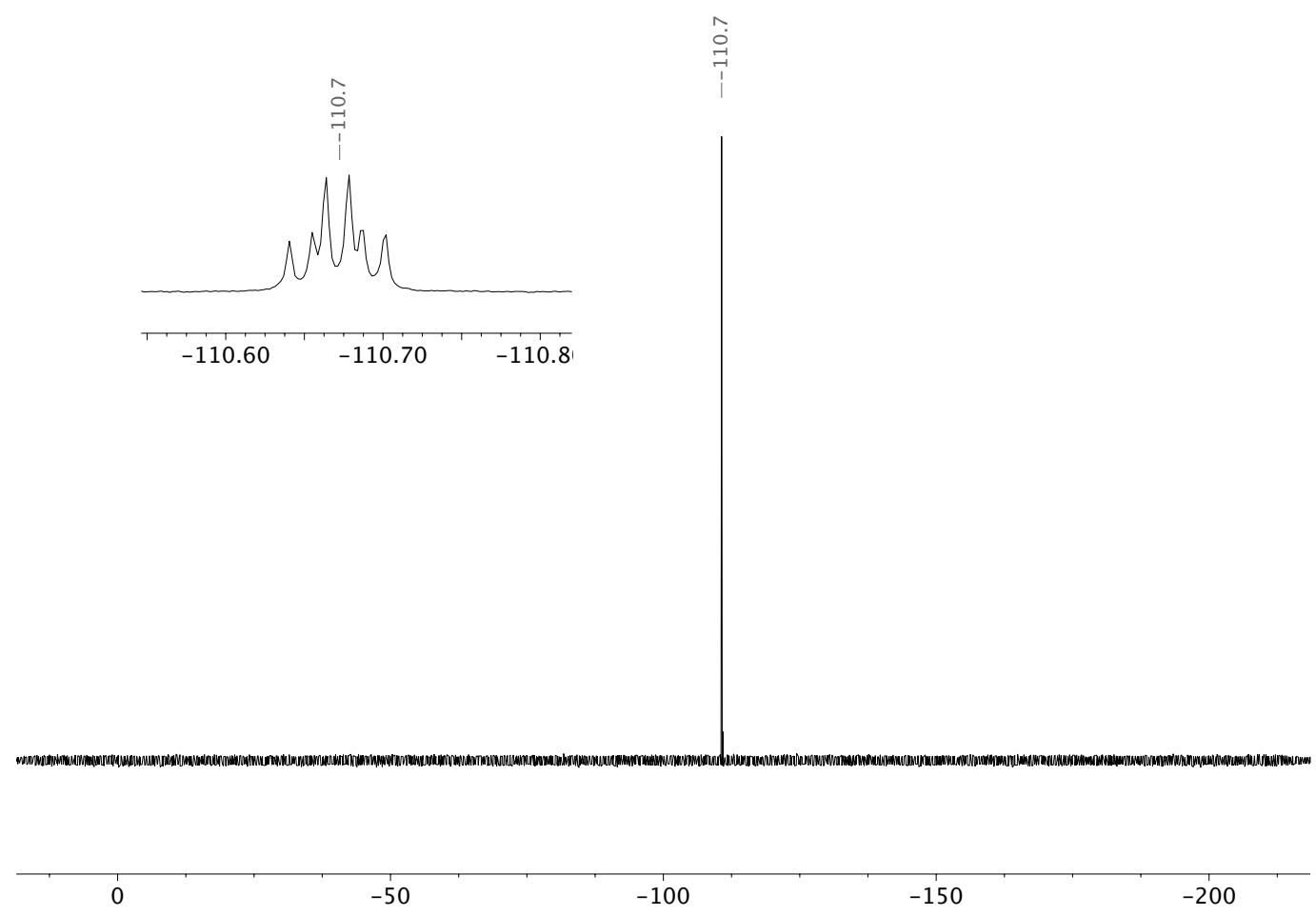


3.1.28. (R)-3-(o-Tolylsulfinyl)-2-quinolone (8I)

${ }^{1} \mathrm{H}$ NMR (500 MHz, DMSO- $\left.d_{6}\right)$

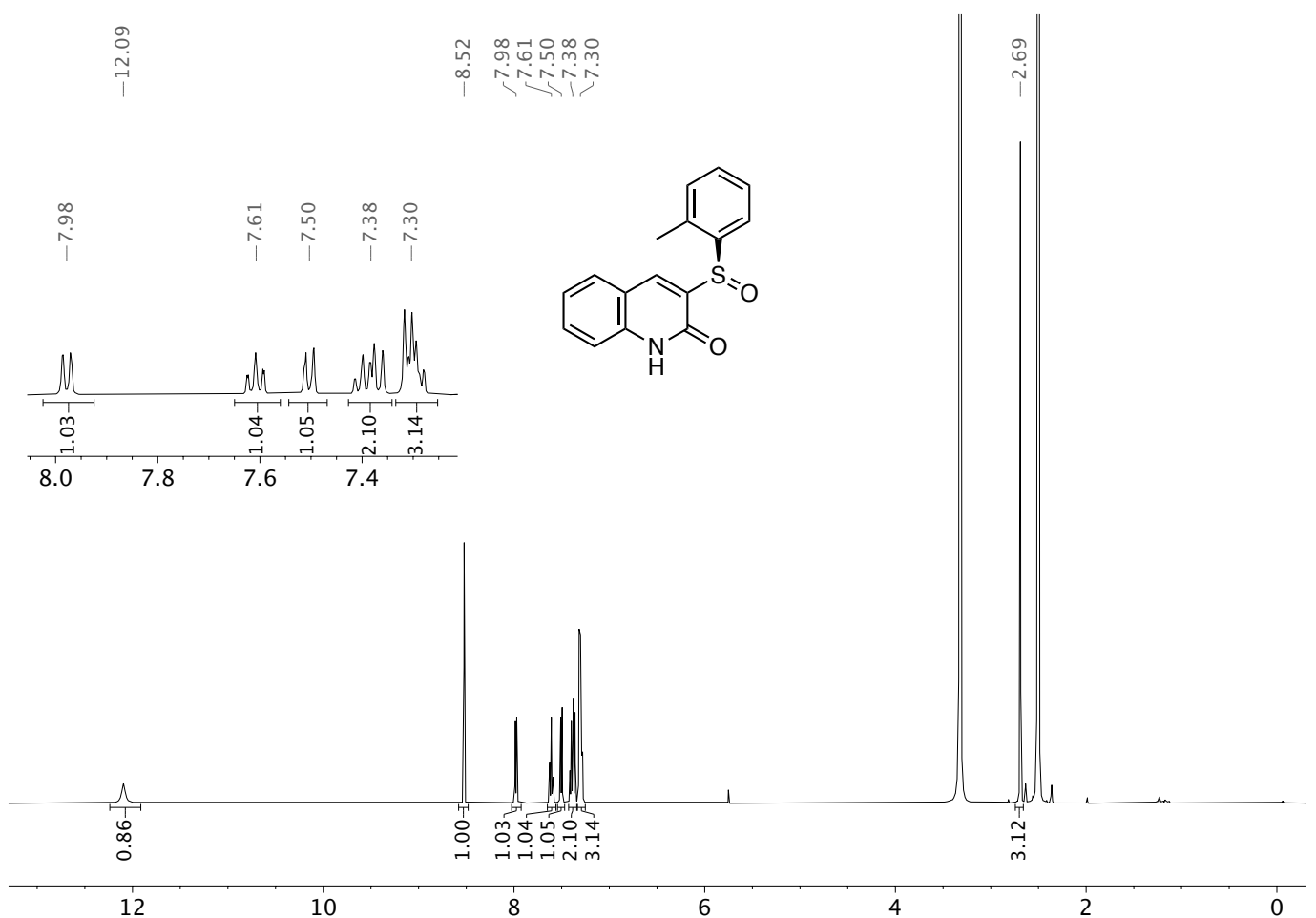

${ }^{13} \mathrm{C}$ NMR (126 MHz, DMSO- $\left.d_{6}\right)$

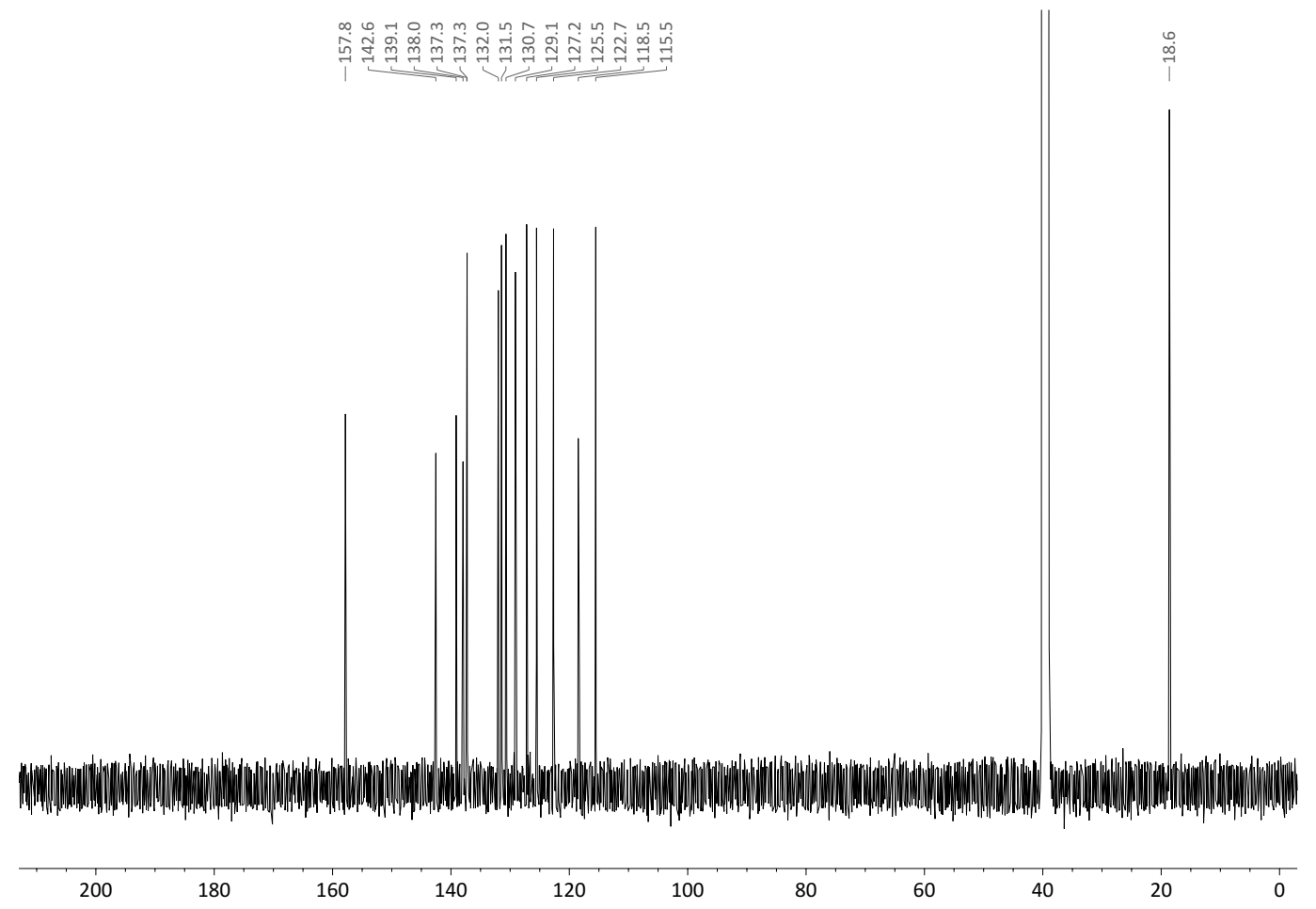


3.1.29. (R)-3-((2-Ethylphenyl)sulfinyl)-2-quinolone (8m)

${ }^{1} \mathrm{H}$ NMR (500 MHz, DMSO- $\left.d_{6}\right)$
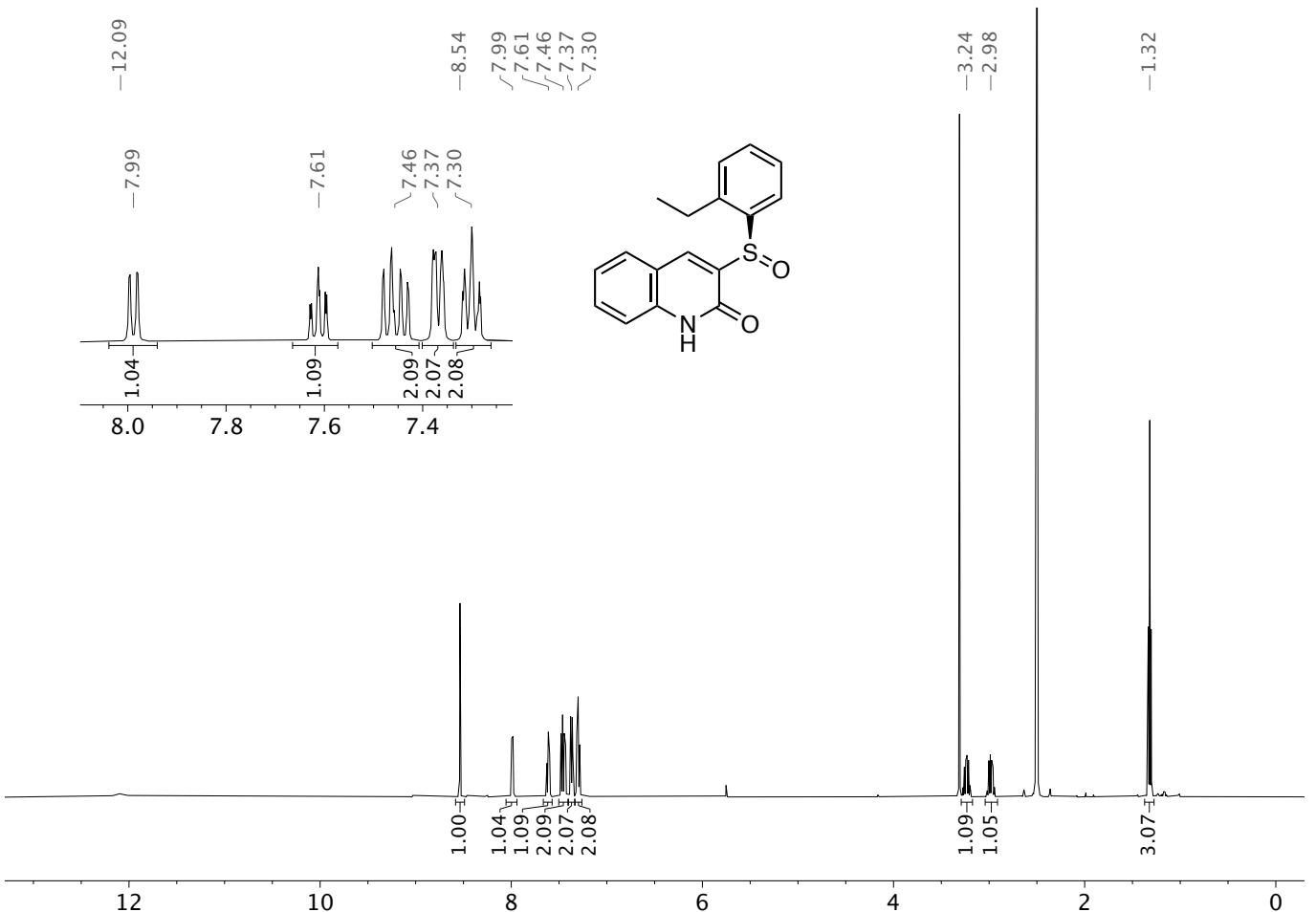

${ }^{13} \mathrm{C}$ NMR $\left(126 \mathrm{MHz}, \mathrm{DMSO}-d_{6}\right)$

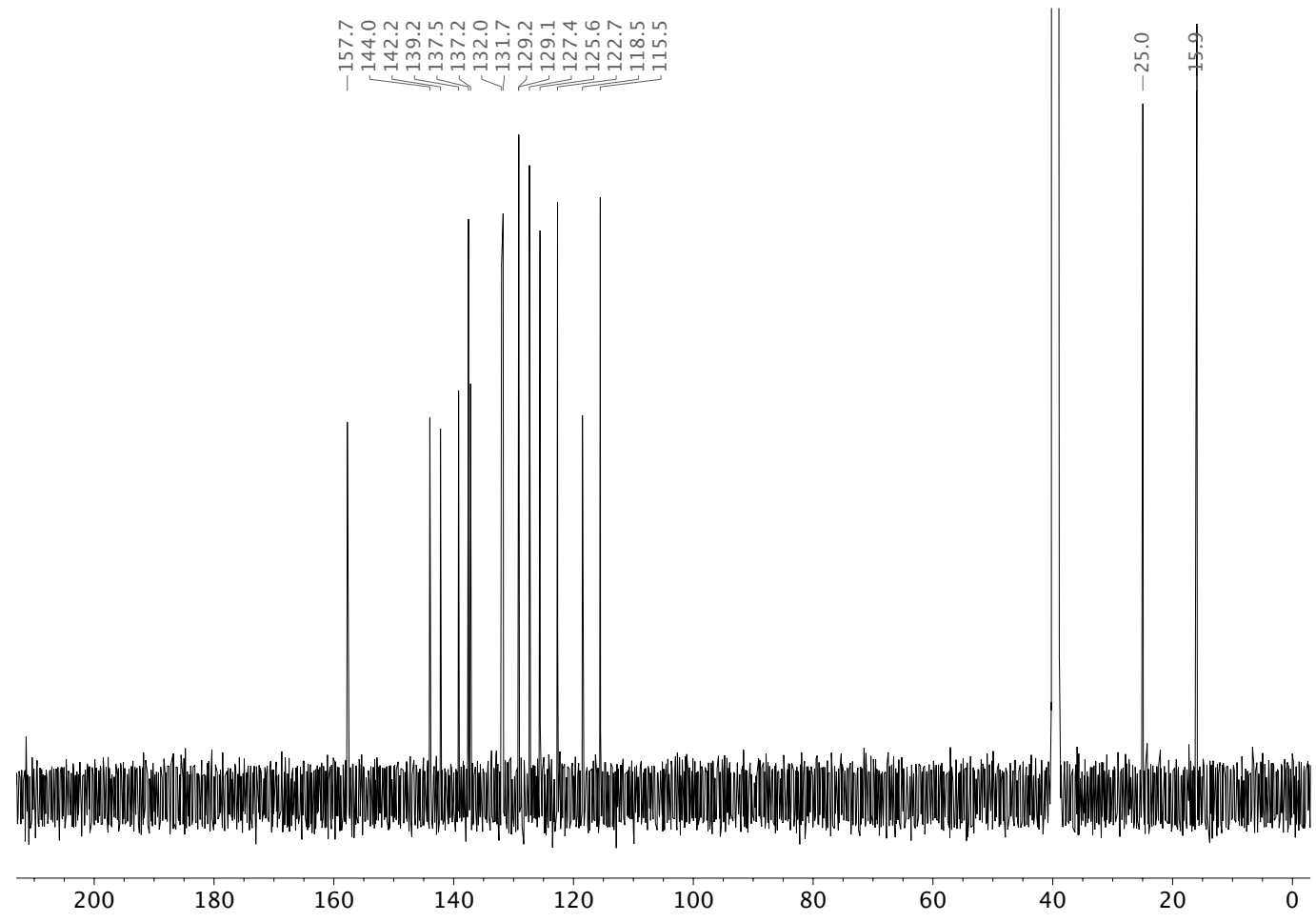


3.1.30. (R)-3-((2-Methoxyphenyl)sulfinyl)-2-quinolone (8n)

${ }^{1} \mathrm{H}$ NMR (500 MHz, DMSO- $d_{6}$ )

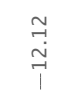

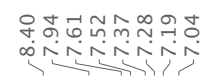

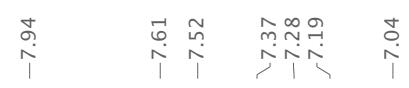

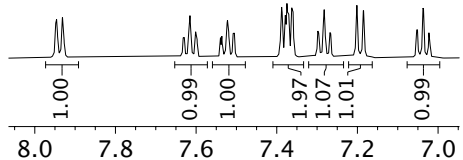<smiles>COc1ccccc1S(=O)c1cc2ccccc2[nH]c1=O</smiles>

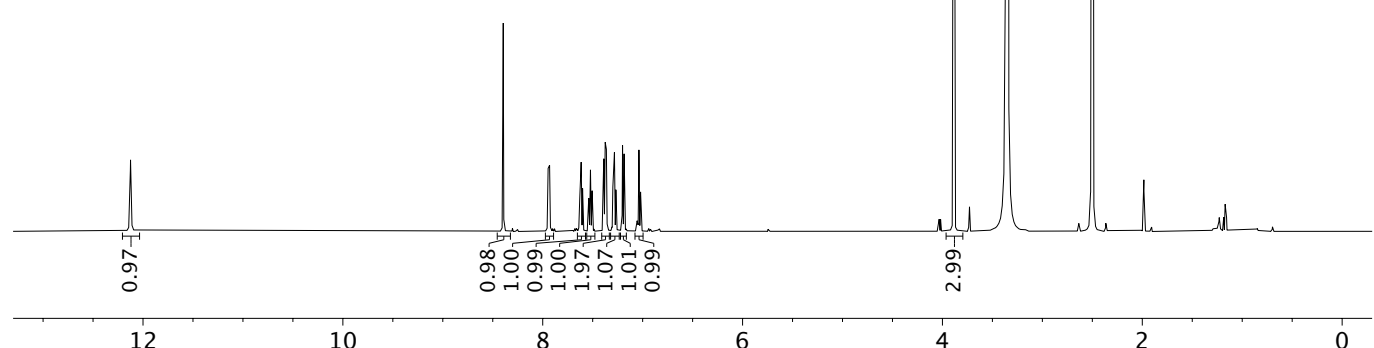

${ }^{13} \mathrm{C}$ NMR $\left(126 \mathrm{MHz}, \mathrm{DMSO}-d_{6}\right)$
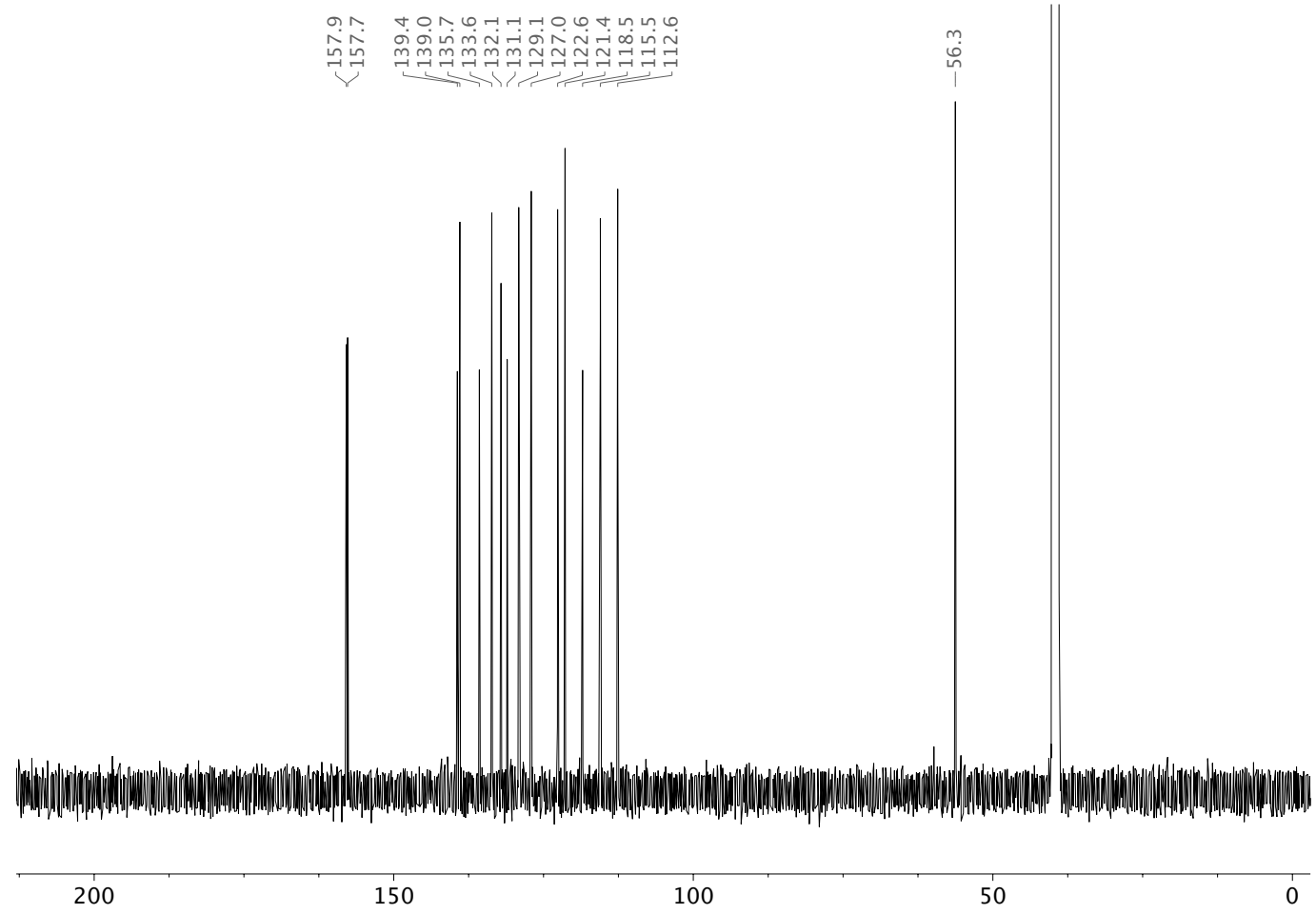
3.1.31. (R)-3-((2,6-Dimethylphenyl)sulfinyl)-2-quinolone (80)

${ }^{1} \mathrm{H}$ NMR $\left(500 \mathrm{MHz}\right.$, DMSO- $\left.d_{6}\right)$

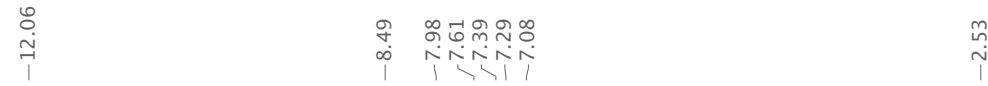

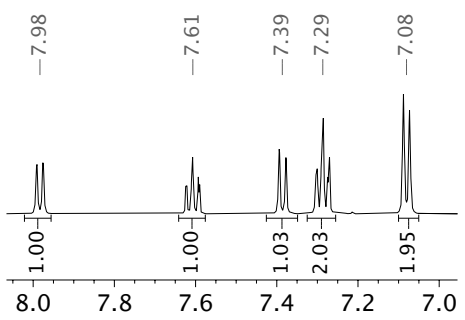<smiles>Cc1cccc(C)c1S(=O)c1cc2ccccc2[nH]c1=O</smiles>

$\tilde{n}$

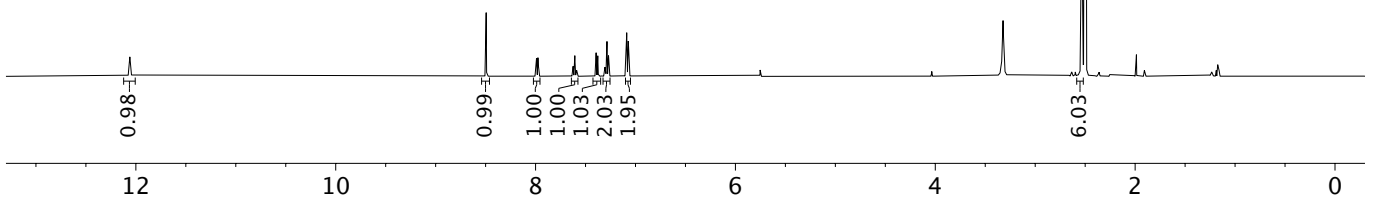

${ }^{13} \mathrm{C}$ NMR (126 MHz, DMSO- $\left.d_{6}\right)$
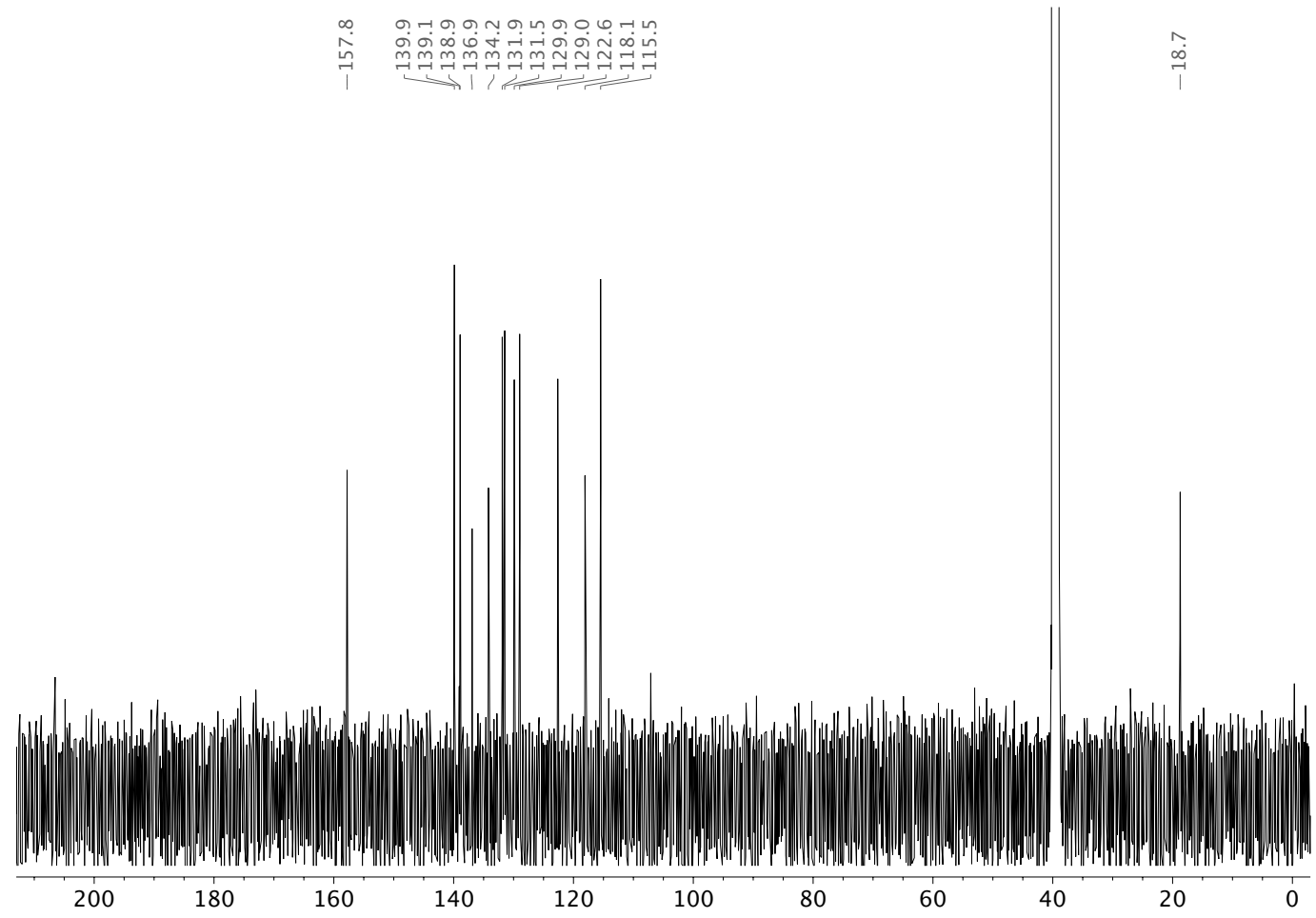
3.1.32. (R)-3-((2,3,5,6-Tetrafluorophenyl)sulfinyl)-2-quinolone (8p)

${ }^{1} \mathrm{H}$ NMR $\left(500 \mathrm{MHz}, \mathrm{DMSO}-d_{6}\right)$

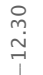

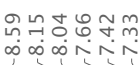<smiles>O=c1[nH]c2ccccc2cc1S(=O)c1c(F)c(F)cc(F)c1F</smiles>

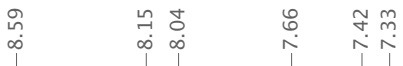

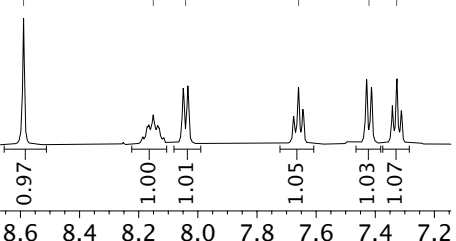

$\begin{array}{lllllllll}8.6 & 8.4 & 8.2 & 8.0 & 7.8 & 7.6 & 7.4 & 7.2\end{array}$
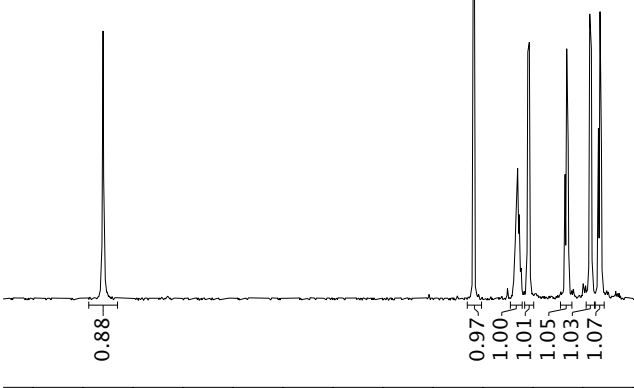

12

10

8

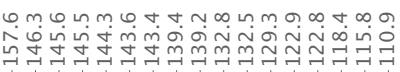

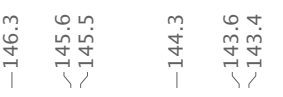

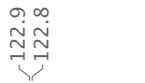
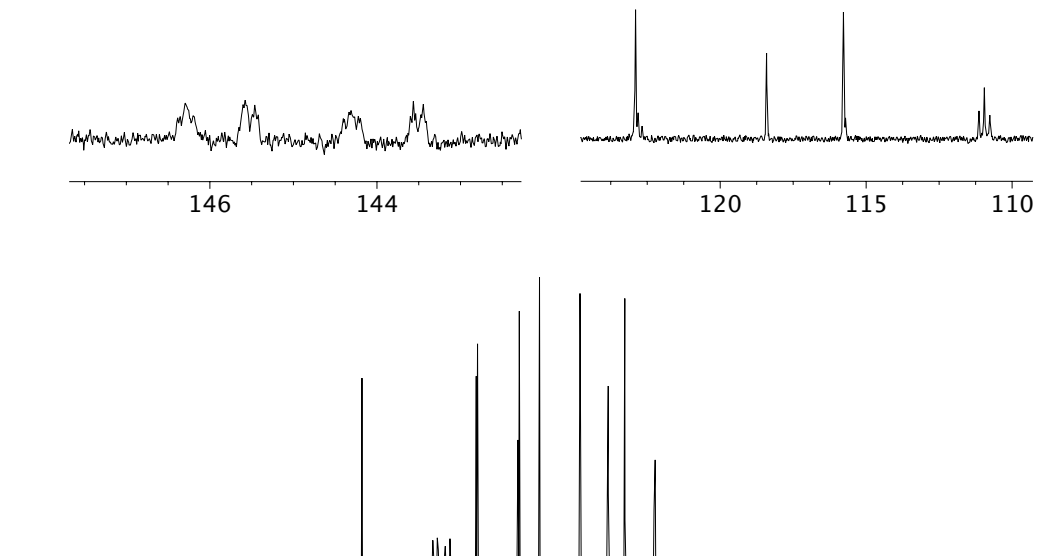

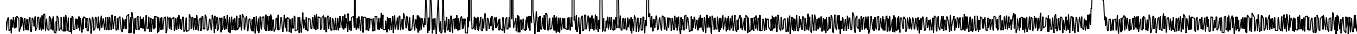

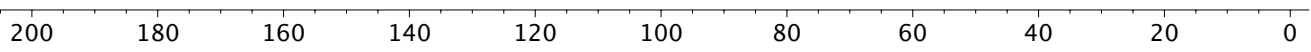


${ }^{19} \mathrm{~F}$ NMR (476 MHz, DMSO- $d_{6}$ )
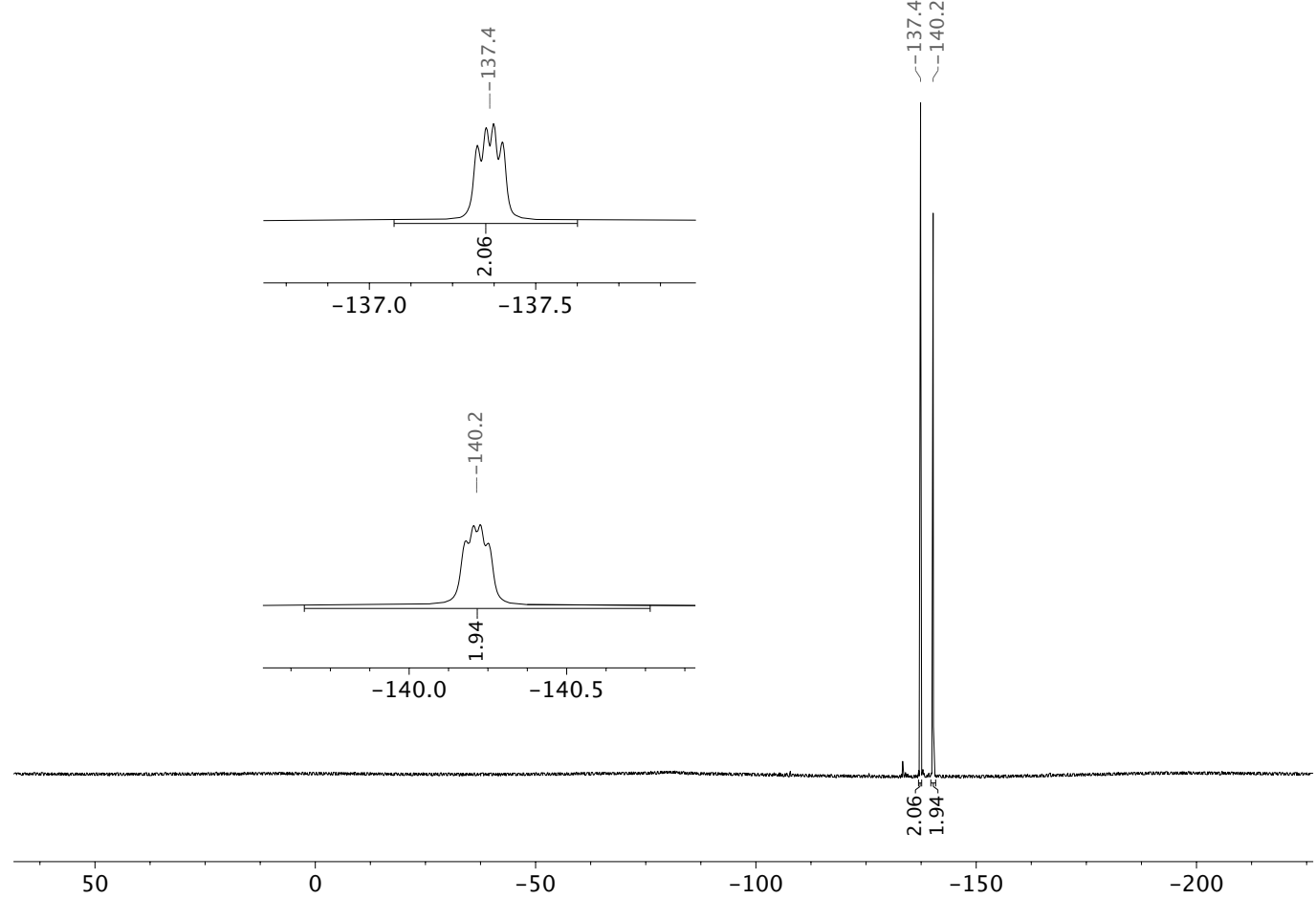
3.1.33. N-Methyl-3-(phenylthio)-2-quinolone (9)

${ }^{1} \mathrm{H}$ NMR $\left(500 \mathrm{MHz}, \mathrm{DMSO}-d_{6}\right)$
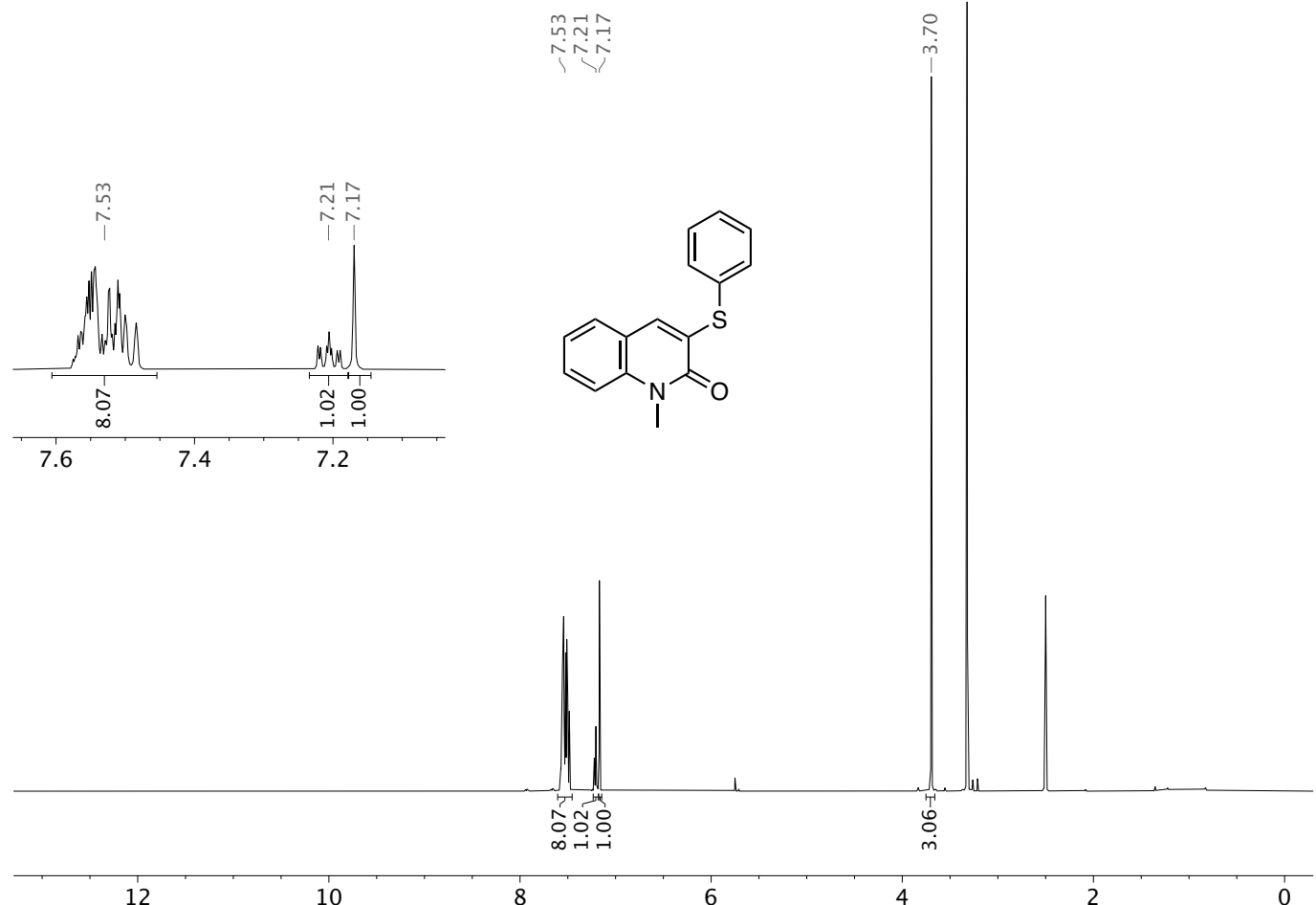

${ }^{13} \mathrm{C}$ NMR (126 MHz, DMSO- $\left.d_{6}\right)$

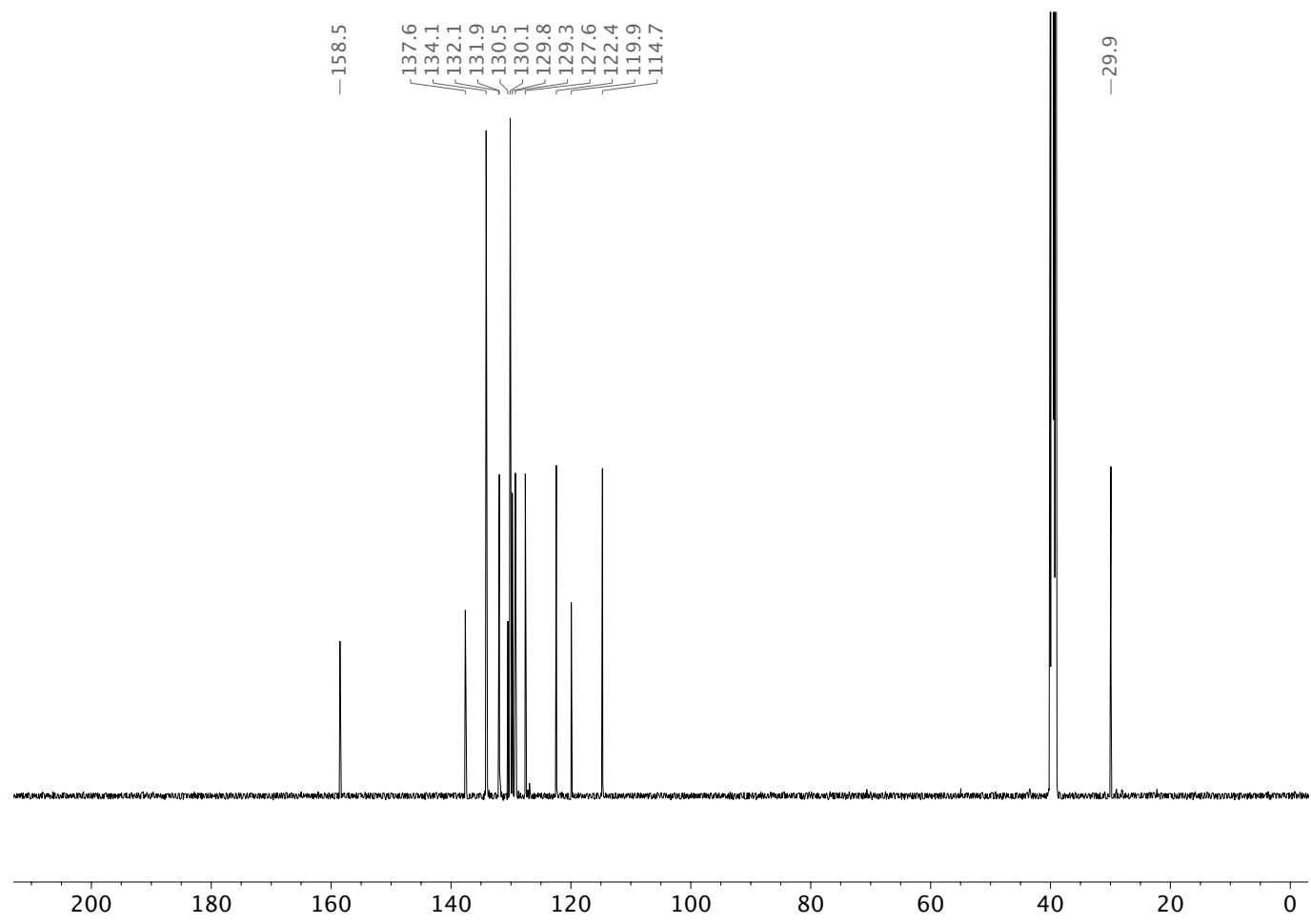


3.1.34. 3-(Phenylthio)-2-coumarin (10)

${ }^{1} \mathrm{H}$ NMR (500 MHz, DMSO- $d_{6}$ )

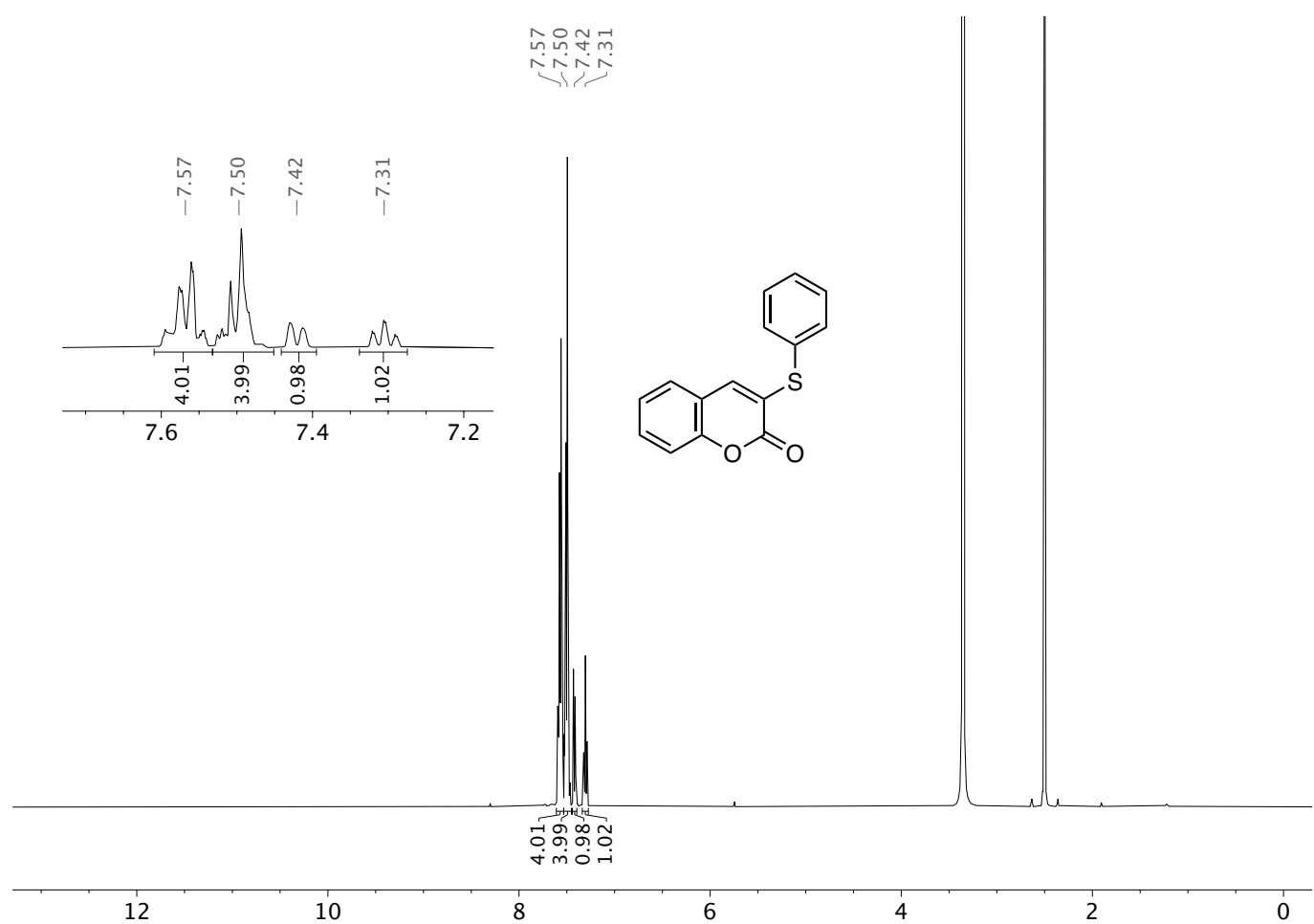

${ }^{13} \mathrm{C}$ NMR (126 MHz, DMSO- $d_{6}$ )

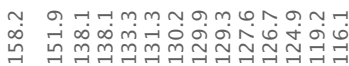

$\overrightarrow{1}+\underbrace{-1-1}$

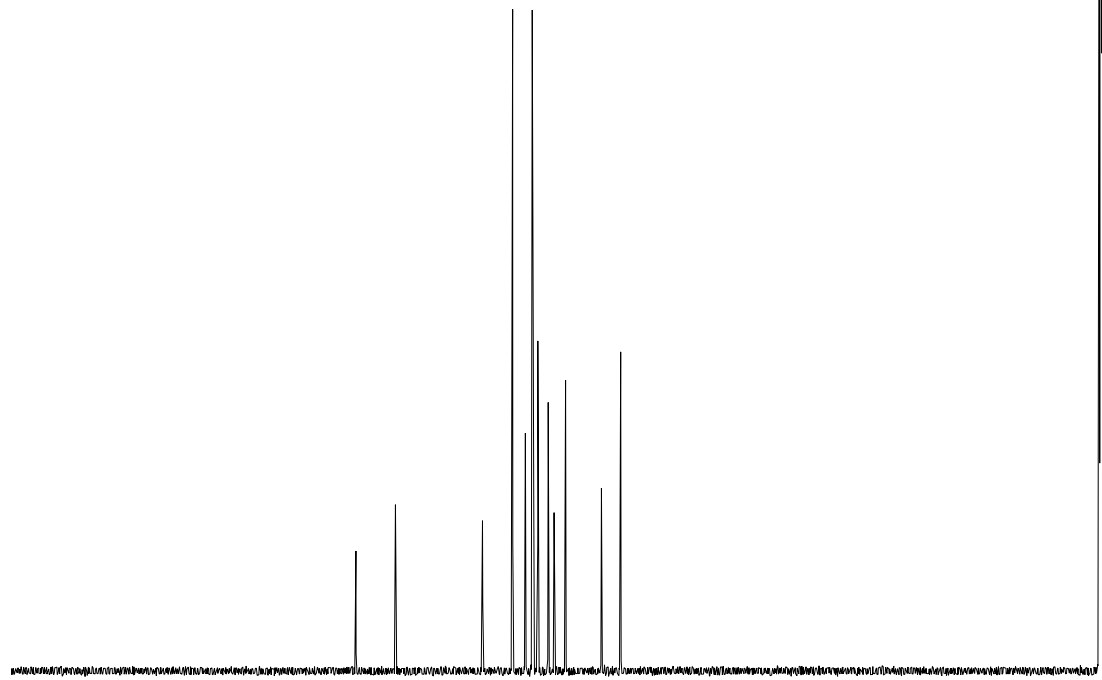

$\begin{array}{llll}200 & 180 & 160 & 140\end{array}$

$120 \quad 100$

80

60

40

20 
3.1.35. N-Methyl-3-(phenylsulfinyl)-2-quinolone (11)

${ }^{1} \mathrm{H}$ NMR (500 MHz, DMSO- $\left.d_{6}\right)$

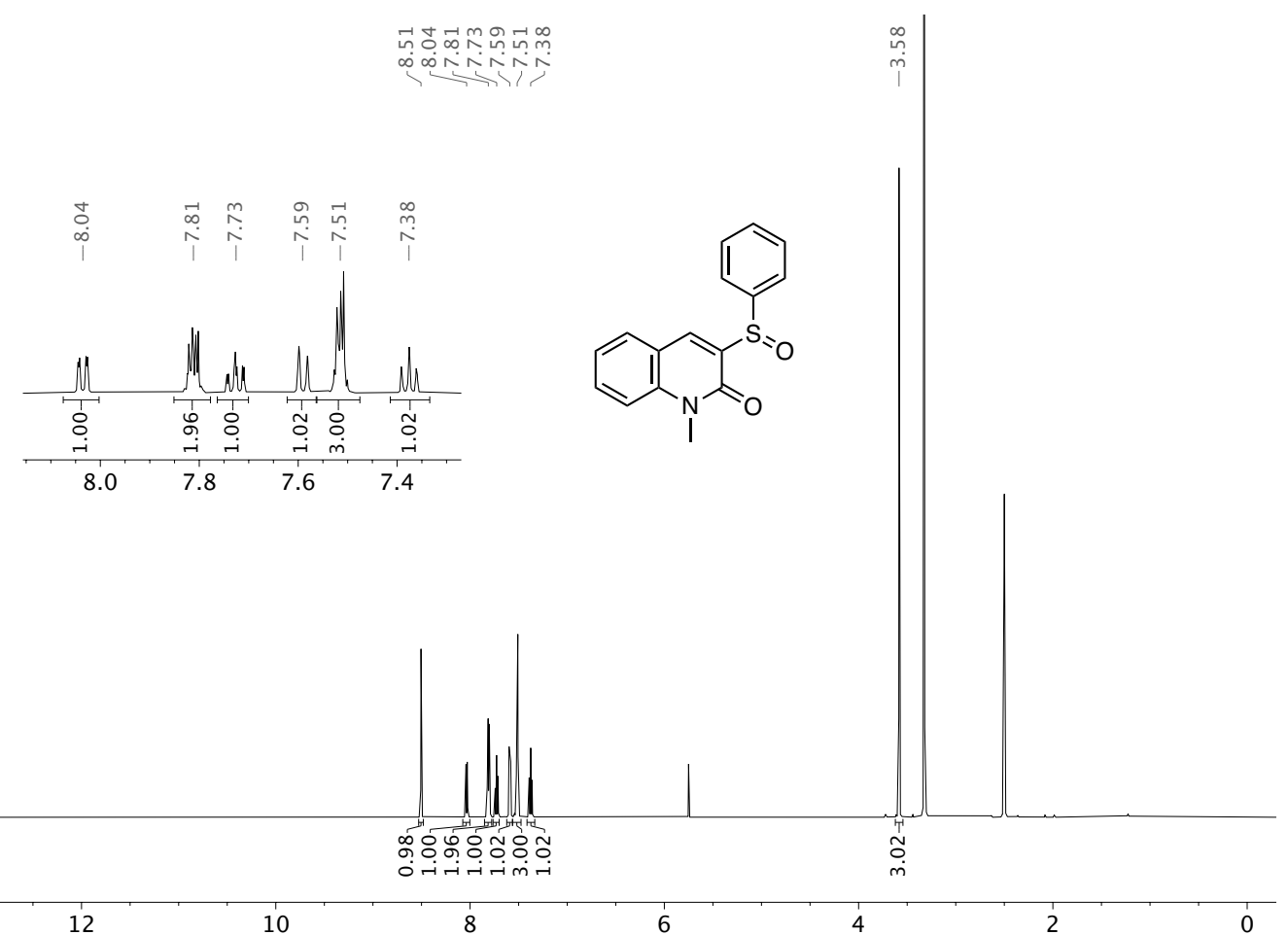

${ }^{13} \mathrm{C}$ NMR (126 MHz, DMSO- $\left.d_{6}\right)$

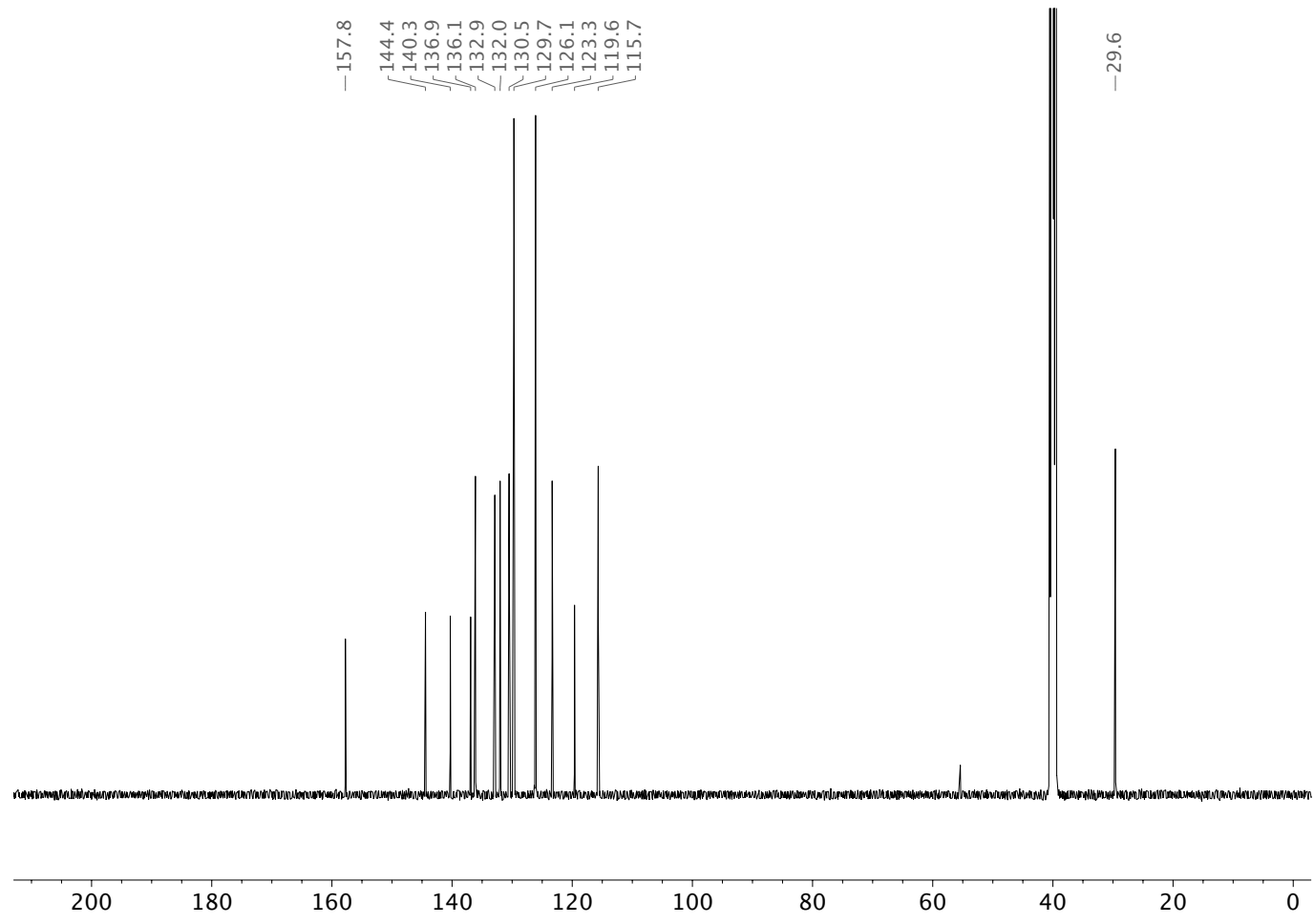


3.1.36. 3-(Phenylsulfinyl)-2-coumarin (12)

${ }^{1} \mathrm{H}$ NMR $\left(500 \mathrm{MHz}\right.$, DMSO- $\left.d_{6}\right)$

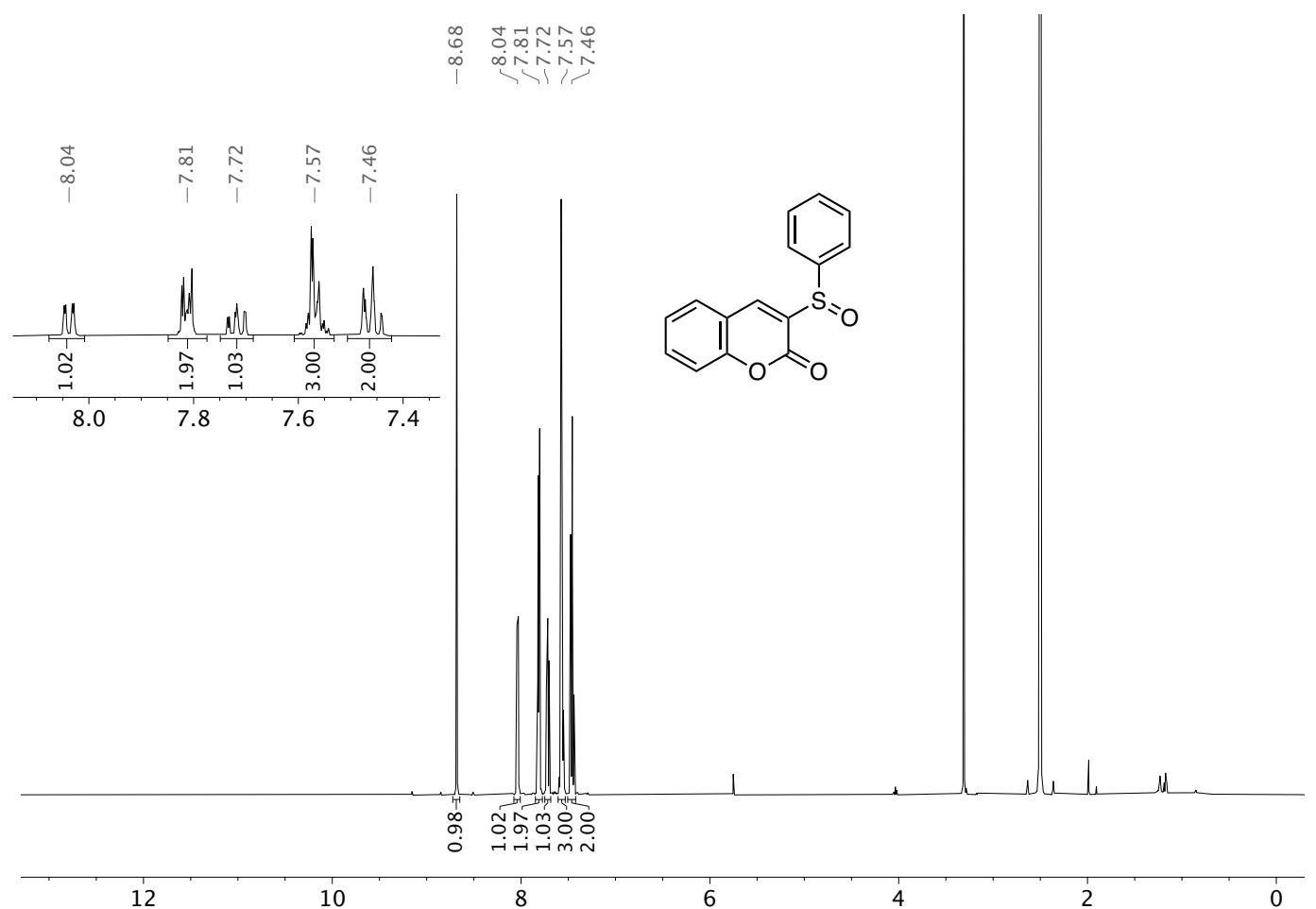

${ }^{13} \mathrm{C}$ NMR $\left(126 \mathrm{MHz}, \mathrm{DMSO}-d_{6}\right)$

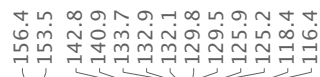

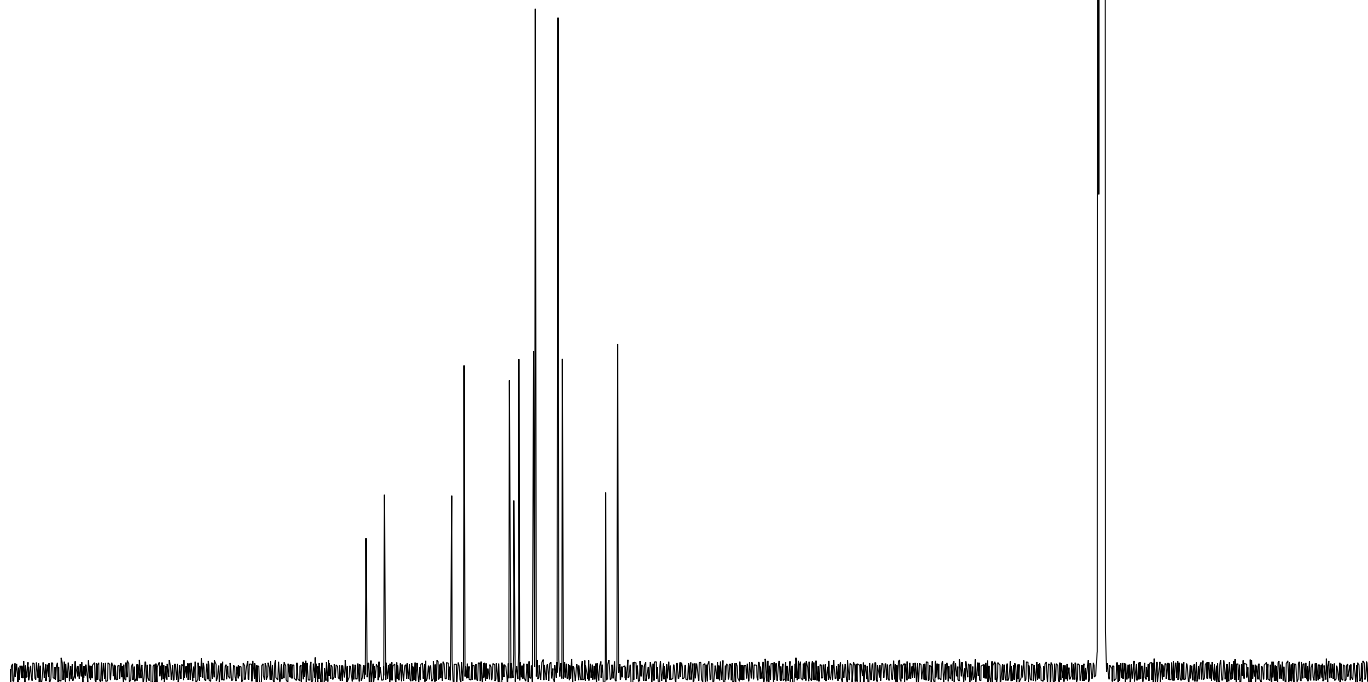

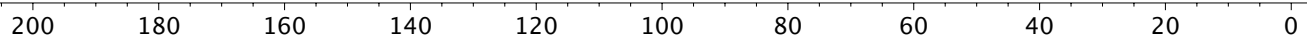


3.1.37. (R)-3-(Phenylsulfonimidoyl)-2-quinolone (15)

${ }^{1} \mathrm{H} \mathrm{NMR}\left(500 \mathrm{MHz}, \mathrm{CDCl}_{3}\right)$

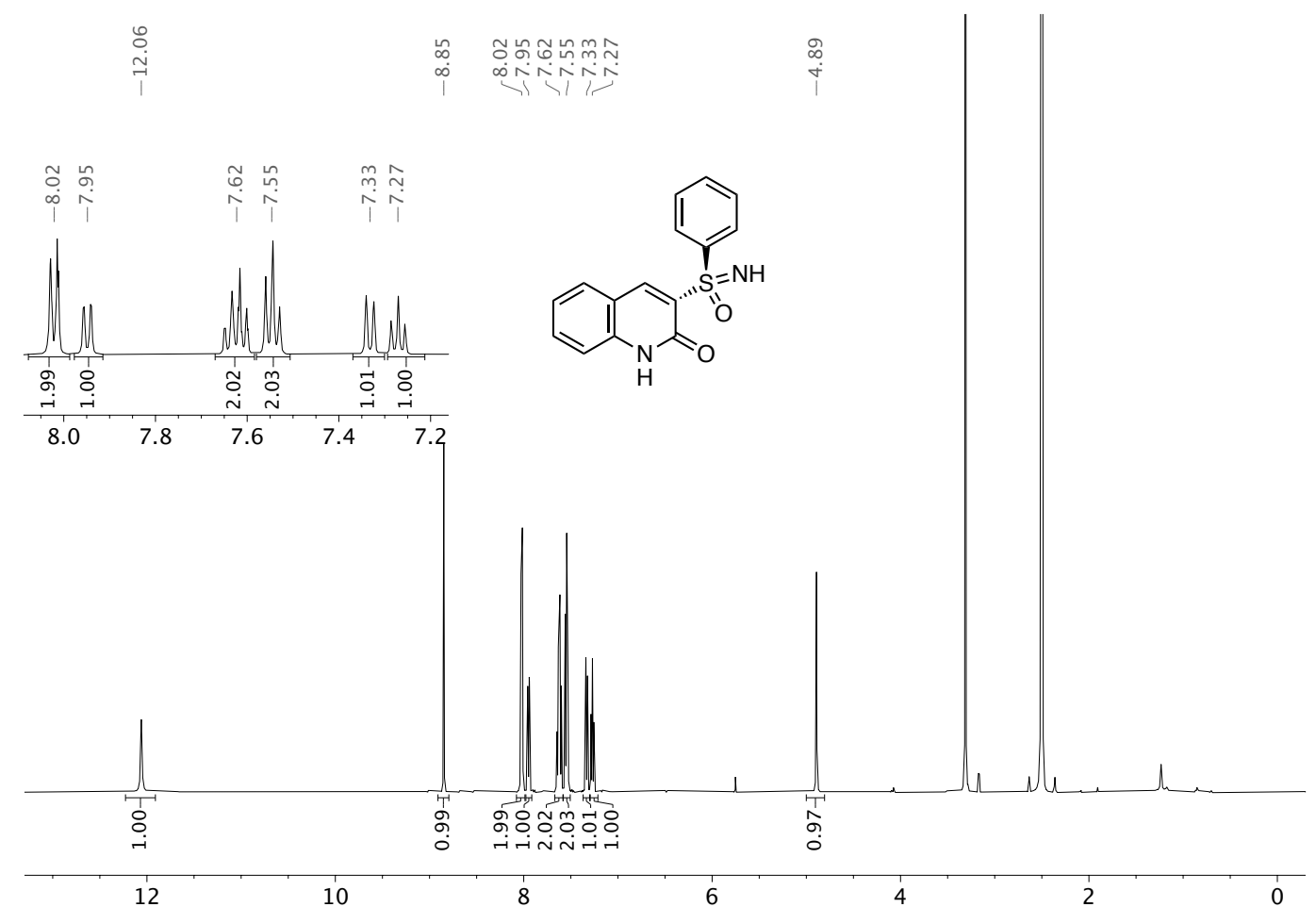

${ }^{13} \mathrm{C} \mathrm{NMR}\left(126 \mathrm{MHz}, \mathrm{CDCl}_{3}\right)$

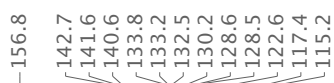

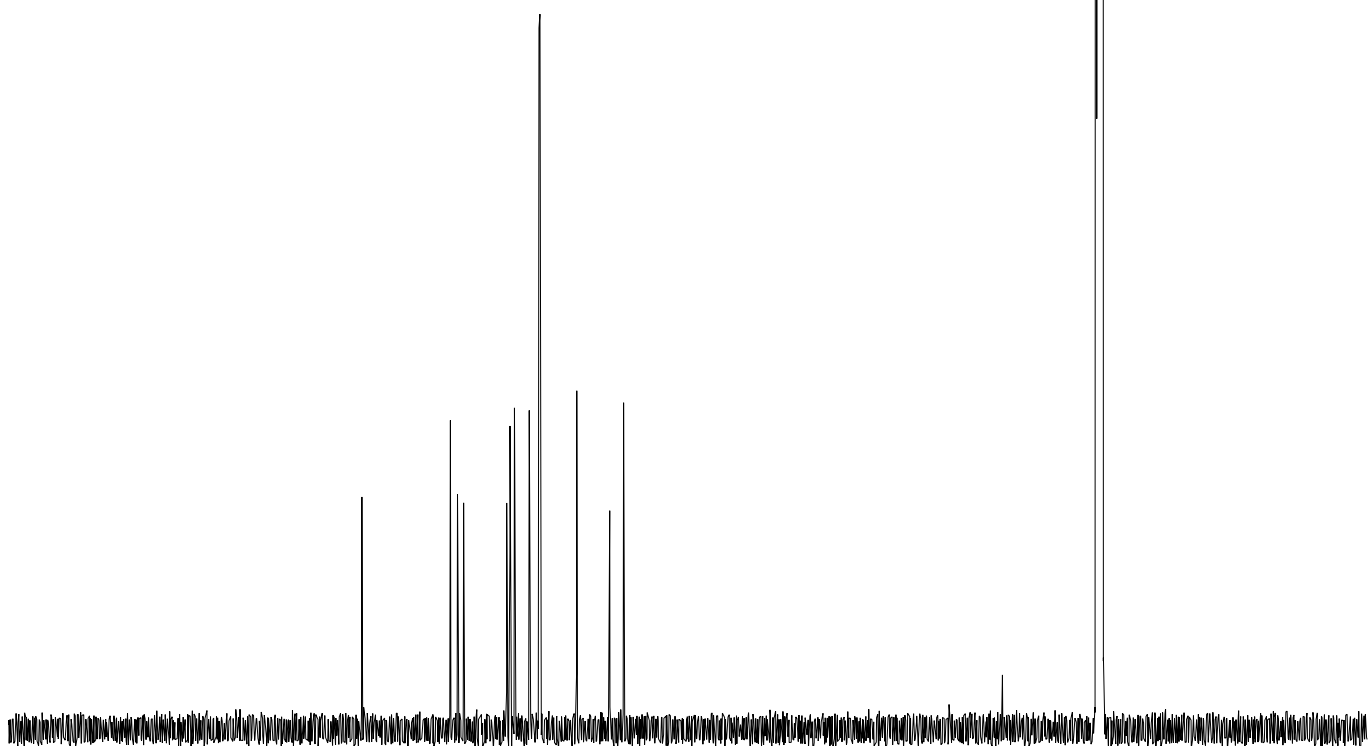

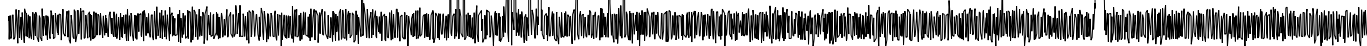

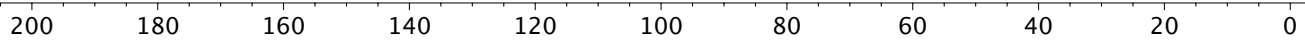


3.1.38. (R)-3-(Phenylsulfinyl)quinolin-2-yl trifluoromethanesulfonate (16)

${ }^{1} \mathrm{H} \mathrm{NMR}\left(500 \mathrm{MHz}, \mathrm{CDCl}_{3}\right)$
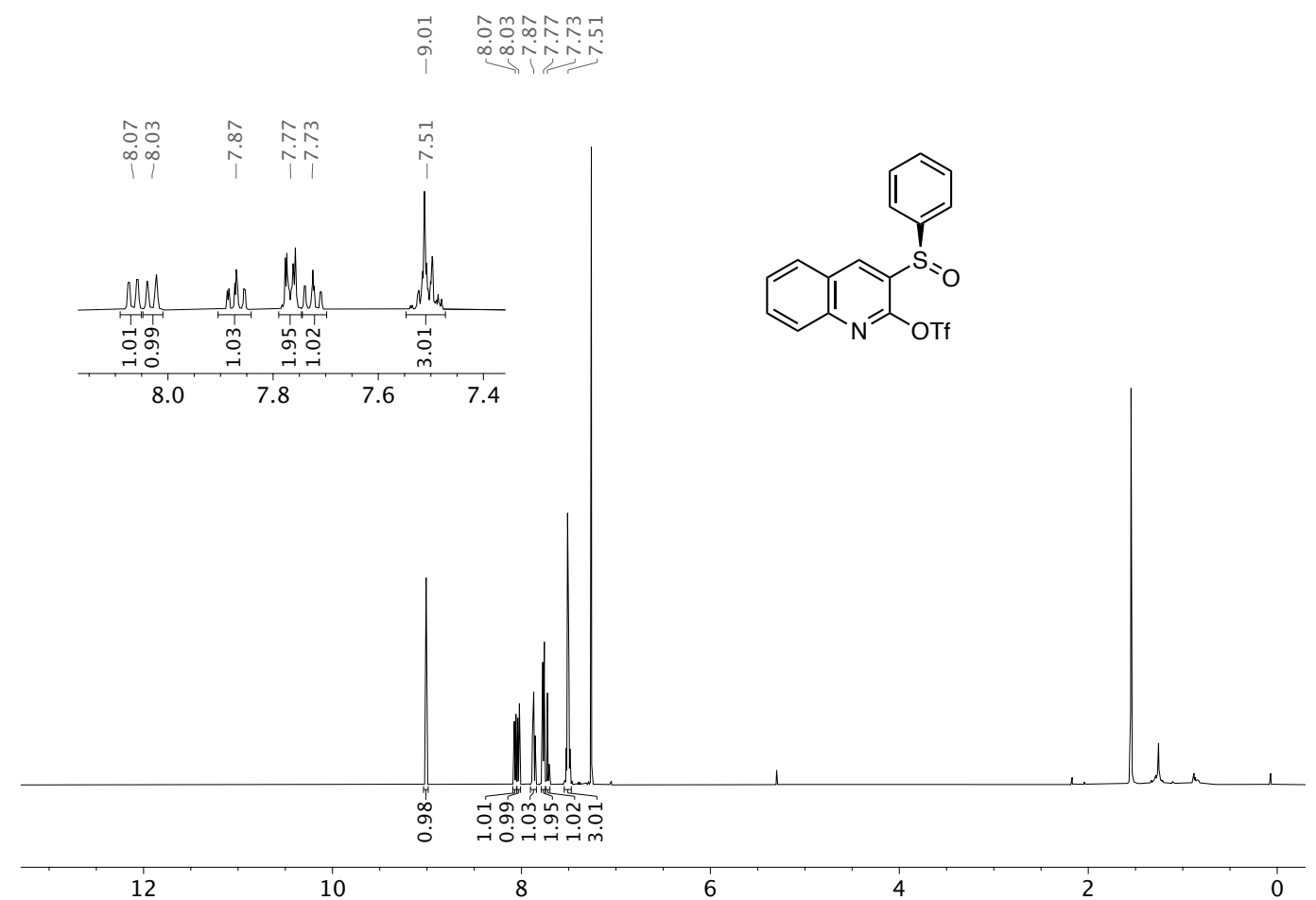

${ }^{13} \mathrm{C} \mathrm{NMR}\left(126 \mathrm{MHz}, \mathrm{CDCl}_{3}\right)$

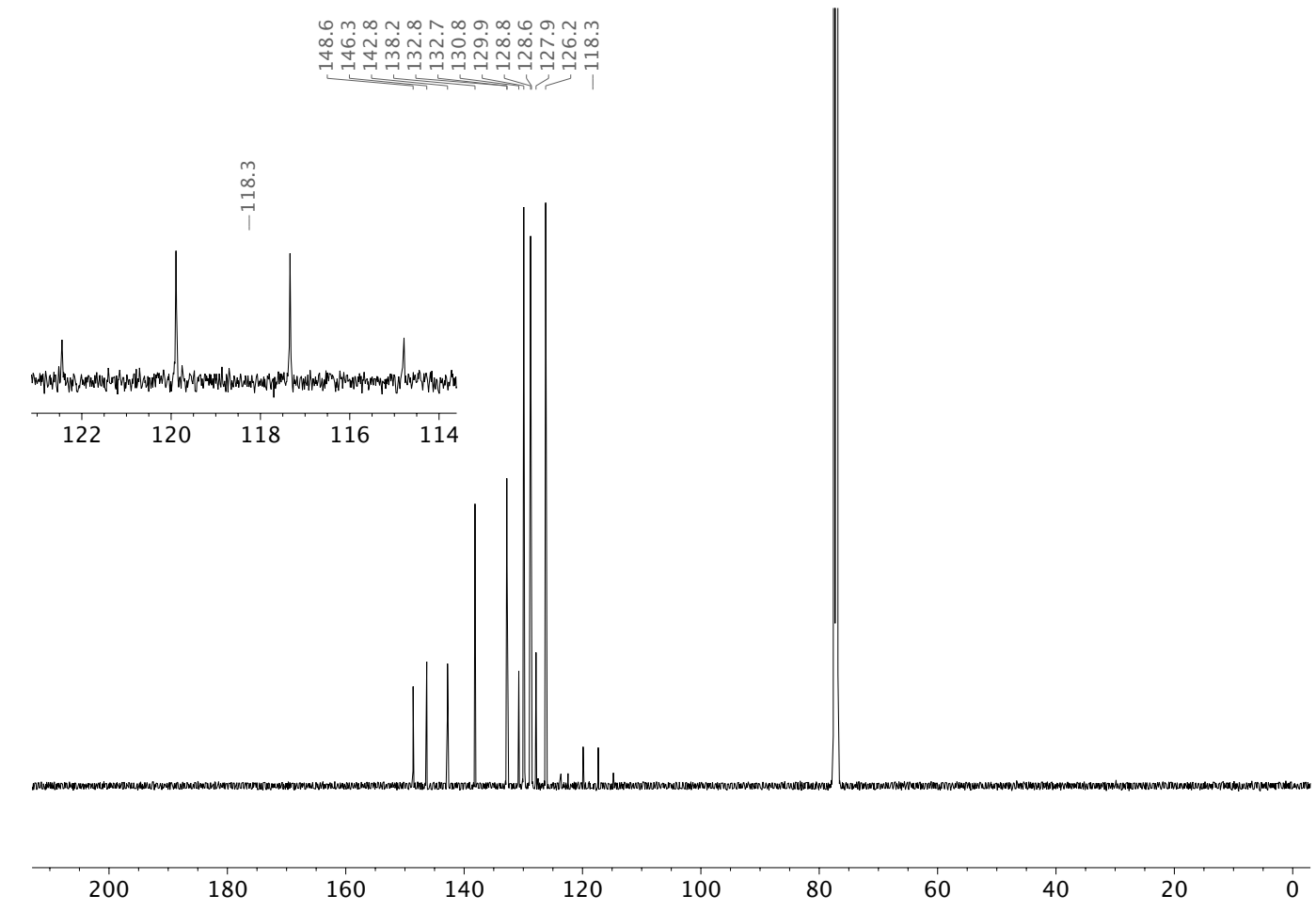


${ }^{19} \mathrm{~F}$ NMR (376 MHz, $\mathrm{CDCl}_{3}$ )

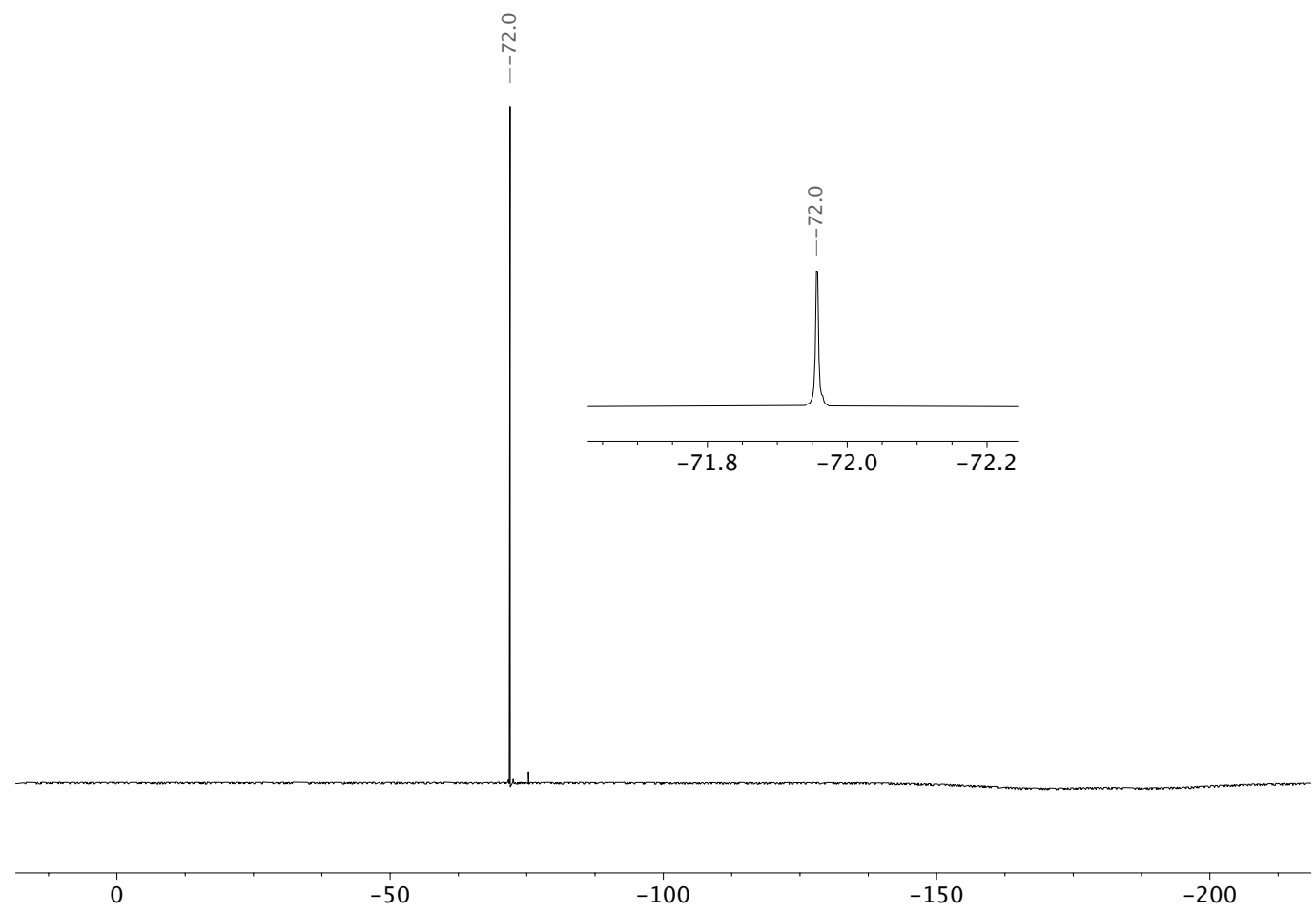


3.1.39. (R)-3-(Phenylsulfinyl)-2-(thiophen-2-yl)quinoline (17)

${ }^{1} \mathrm{H} \mathrm{NMR}\left(500 \mathrm{MHz}, \mathrm{CDCl}_{3}\right)$

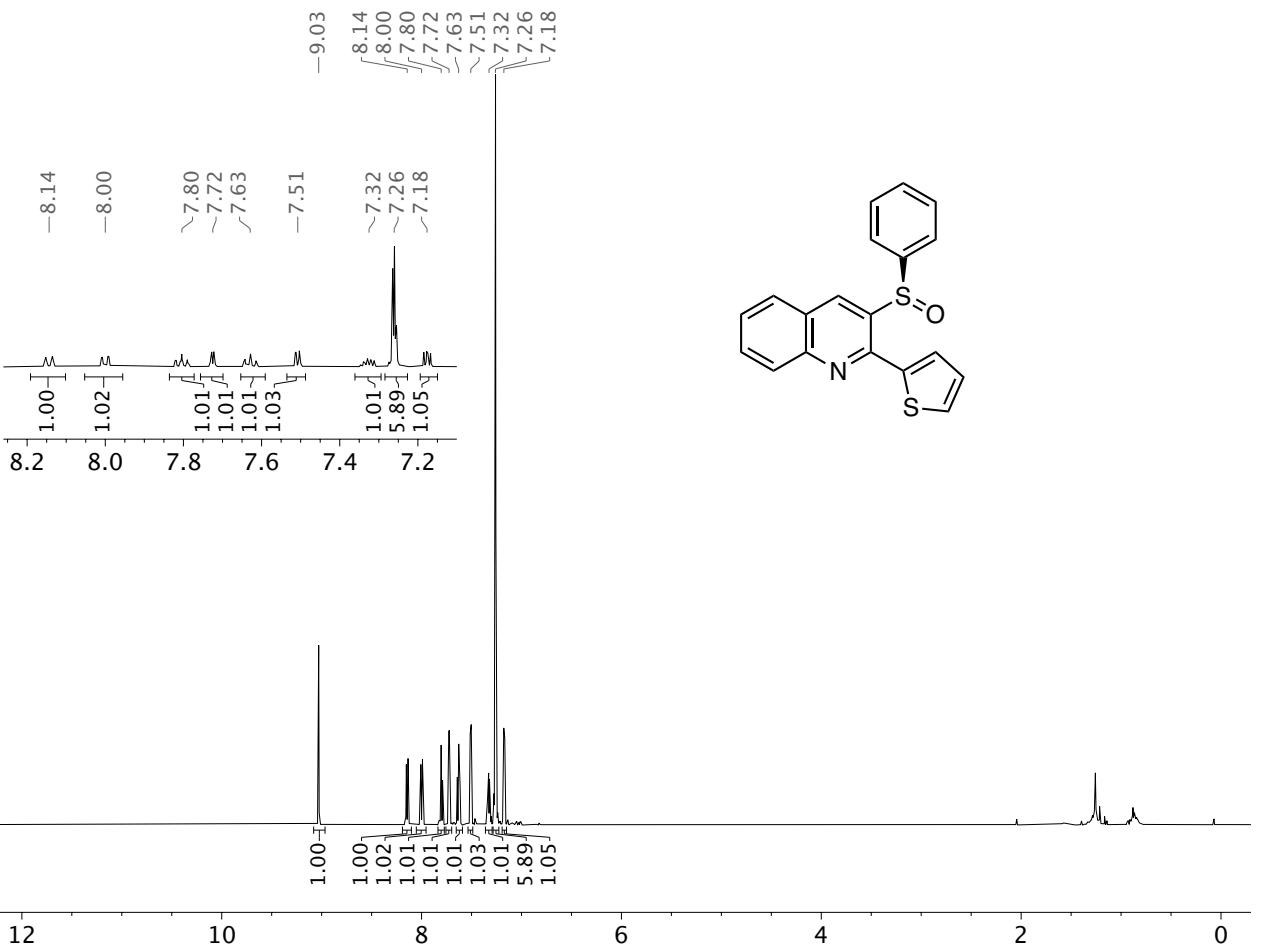

${ }^{13} \mathrm{C} \mathrm{NMR}\left(126 \mathrm{MHz}, \mathrm{CDCl}_{3}\right)$

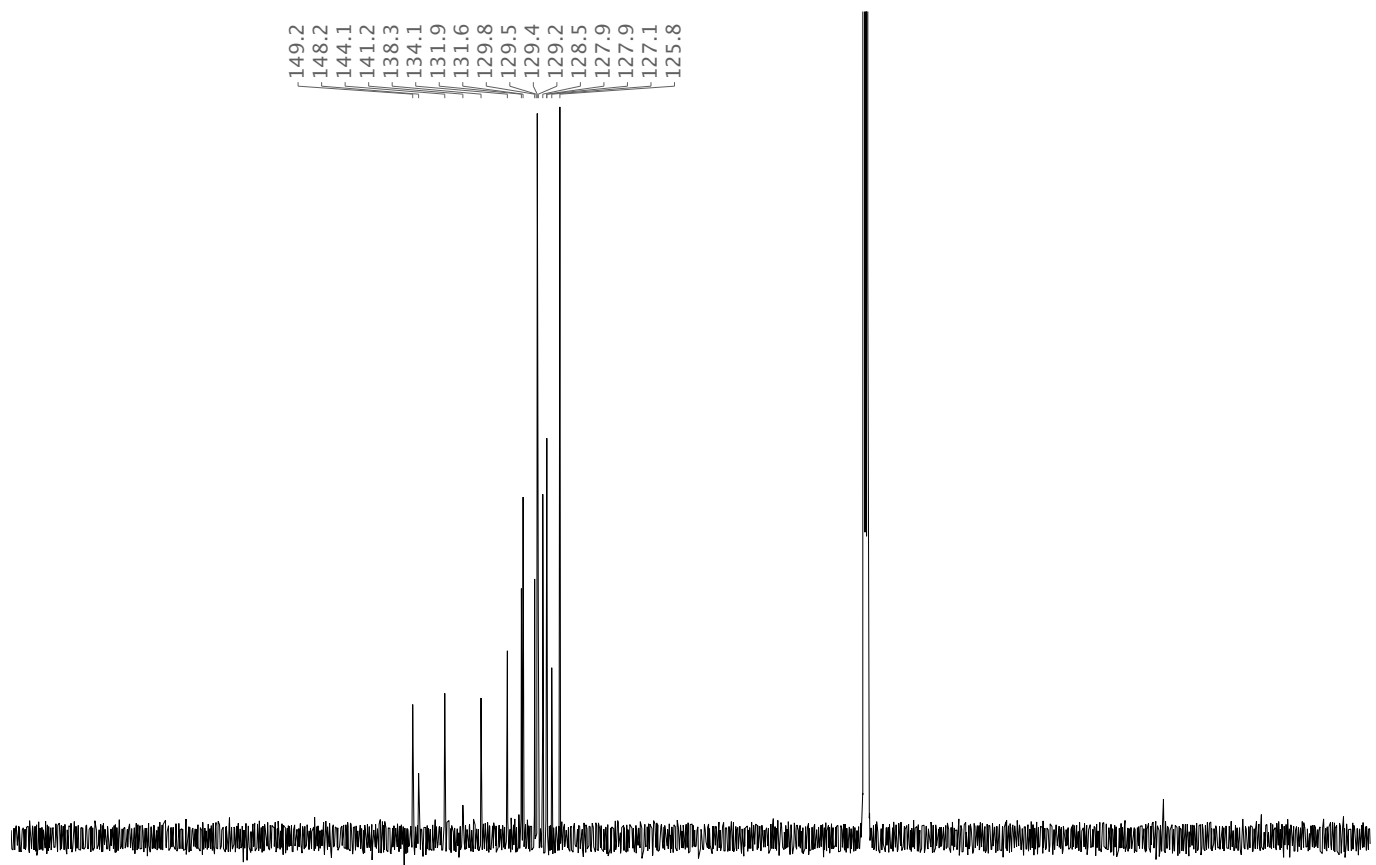

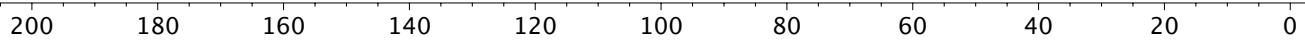


3.1.40. (R)-3-(Phenylsulfinyl)quinoline (18)

${ }^{1} \mathrm{H}$ NMR $\left(500 \mathrm{MHz}, \mathrm{CDCl}_{3}\right)$

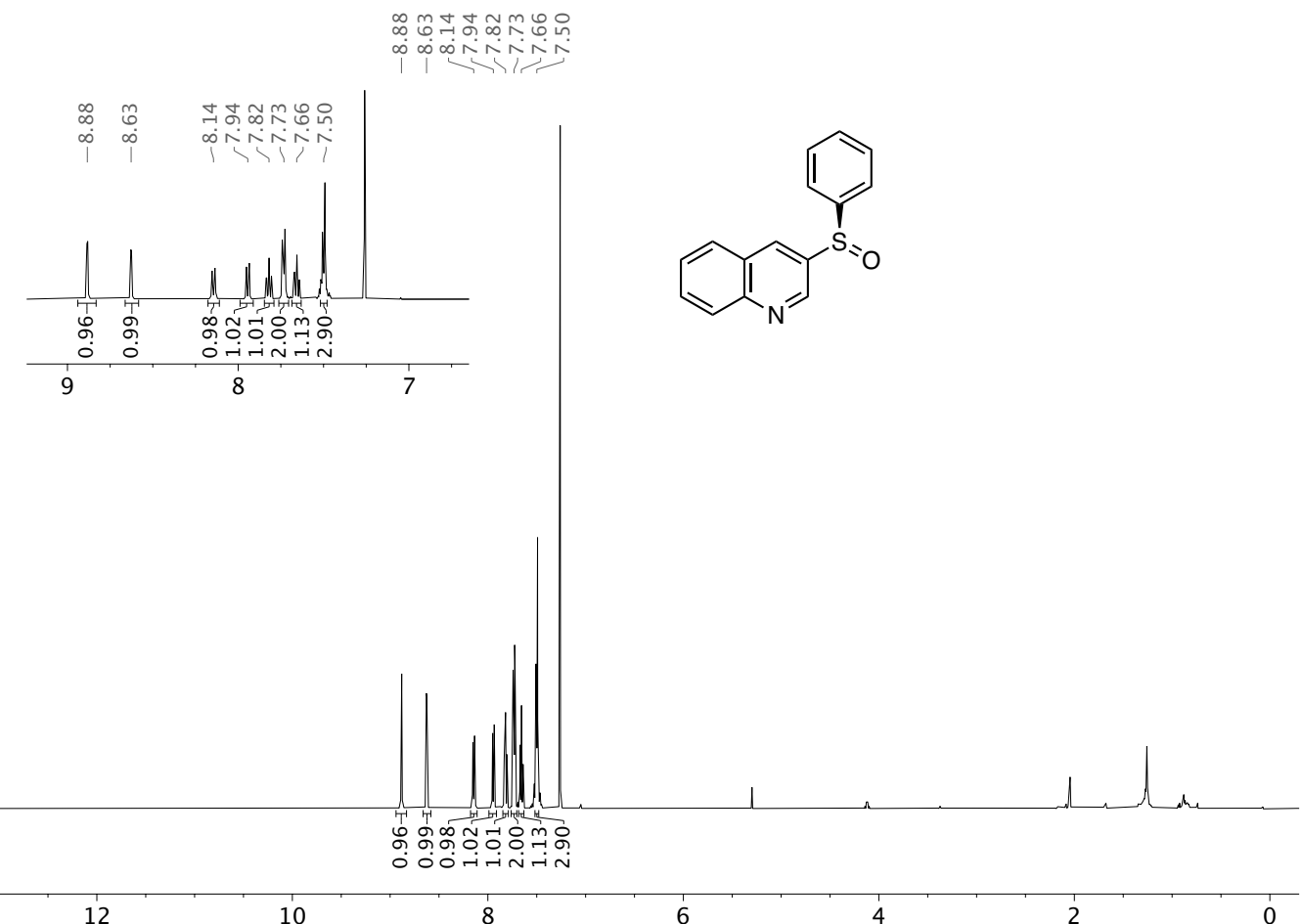

${ }^{13} \mathrm{C}$ NMR $\left(126 \mathrm{MHz}, \mathrm{CDCl}_{3}\right)$

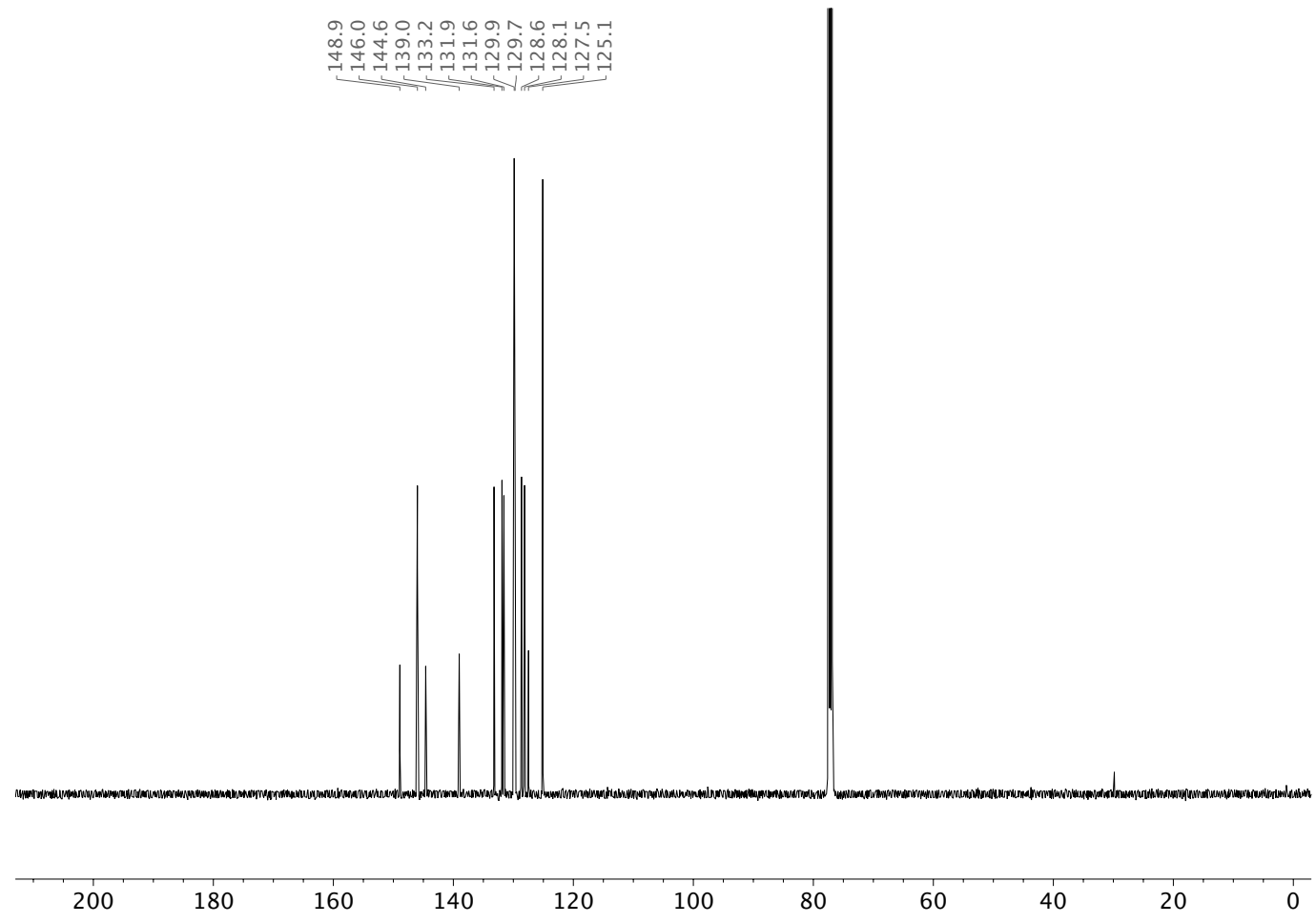


3.1.41. (R)-4-(3-(Phenylsulfinyl)quinolin-2-yl)morpholine (19a)

${ }^{1} \mathrm{H} \mathrm{NMR}\left(500 \mathrm{MHz}, \mathrm{CDCl}_{3}\right)$

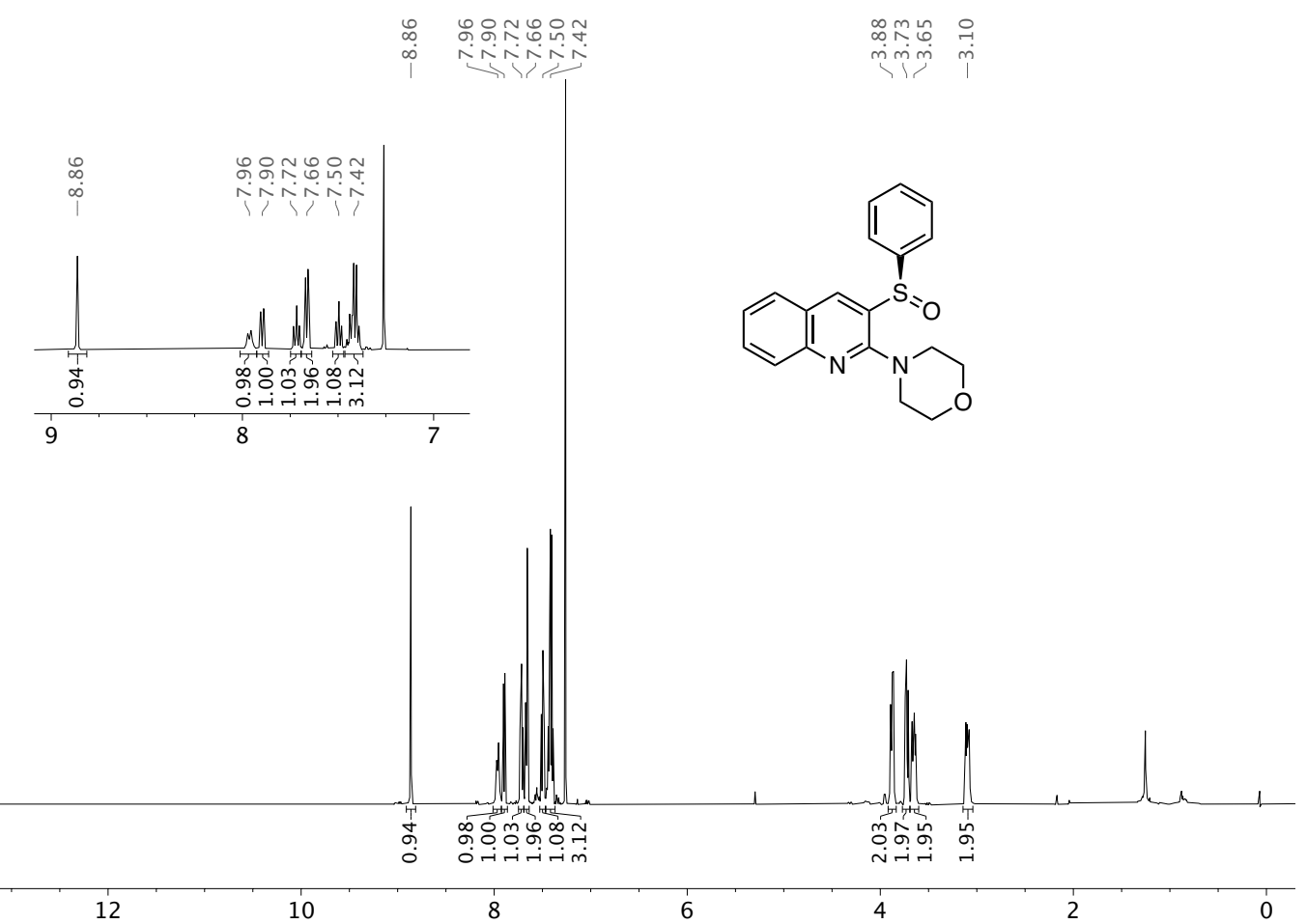

${ }^{13} \mathrm{C} \mathrm{NMR}\left(126 \mathrm{MHz}, \mathrm{CDCl}_{3}\right)$

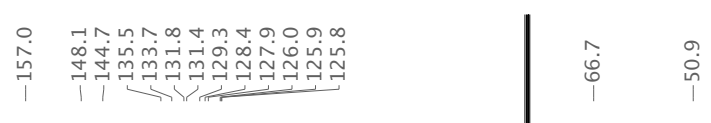

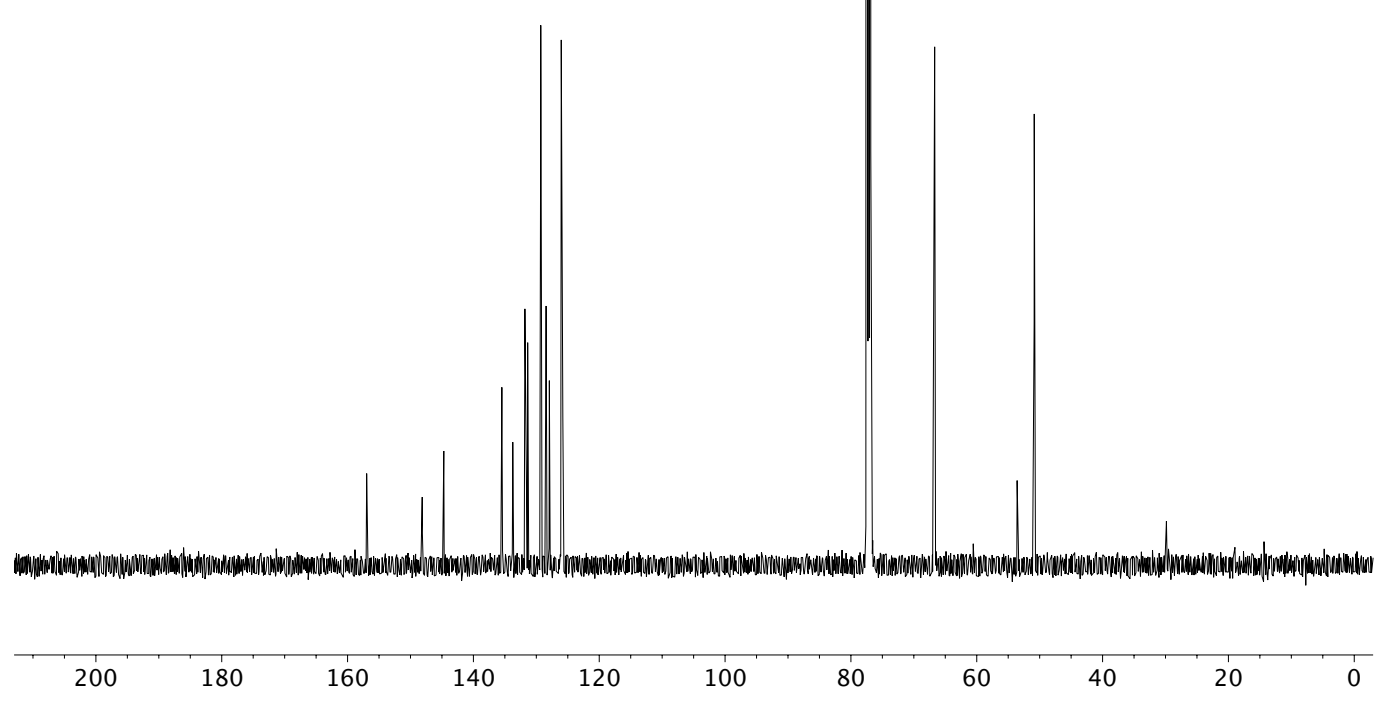


3.1.42. (R)-4-(3-(Phenylsulfinyl)quinolin-2-yl)-N-Boc-piperazine (19b)

${ }^{1} \mathrm{H} \mathrm{NMR}\left(500 \mathrm{MHz}, \mathrm{CDCl}_{3}\right)$

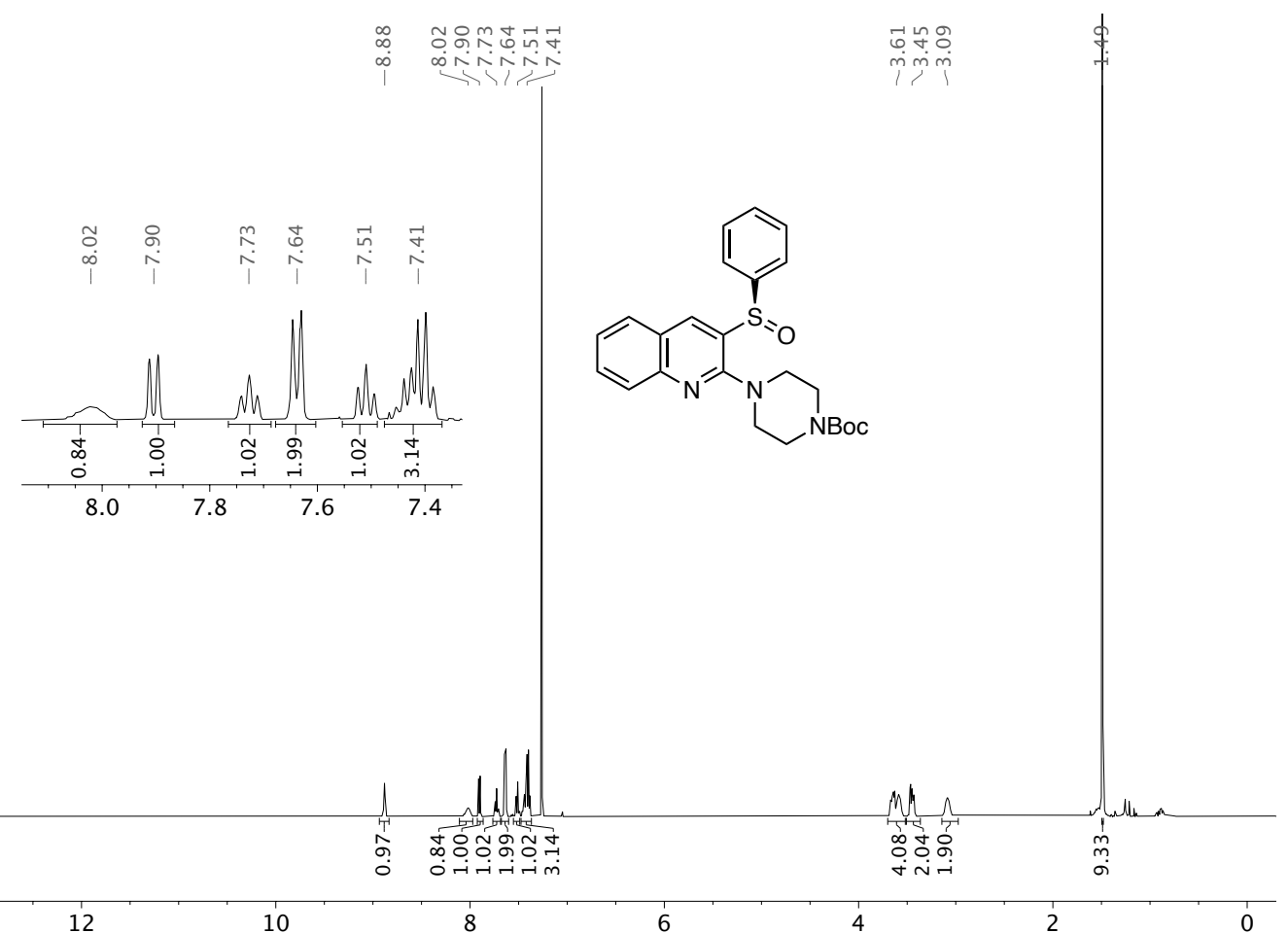

$\left.{ }^{13} \mathrm{C} \mathrm{NMR} \mathrm{(126} \mathrm{MHz,} \mathrm{CDCl}_{3}\right)$

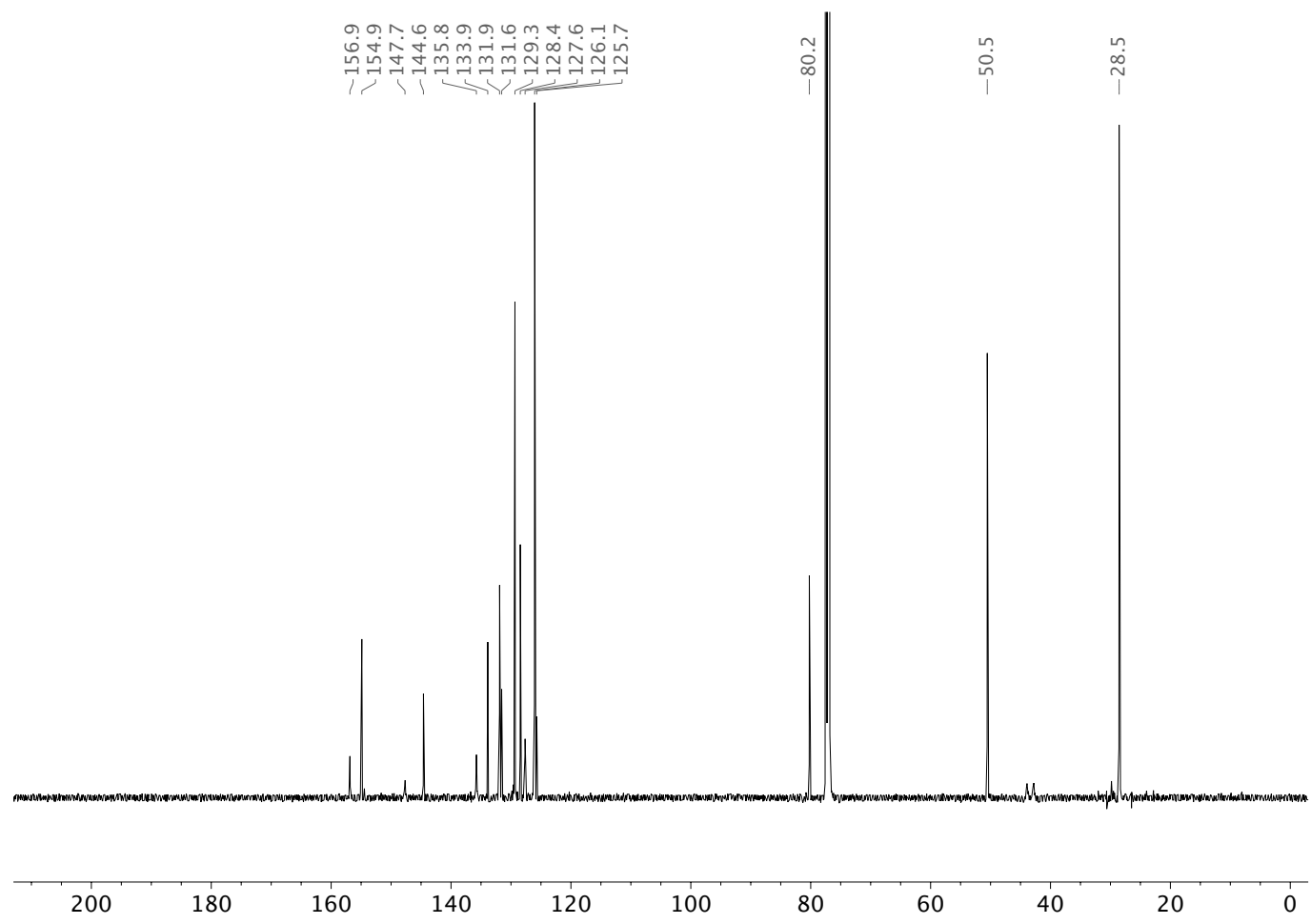




\subsection{HPLC traces}

3.2.1. (R)-3-(Phenylsulfinyl)-2-quinolone (8a)

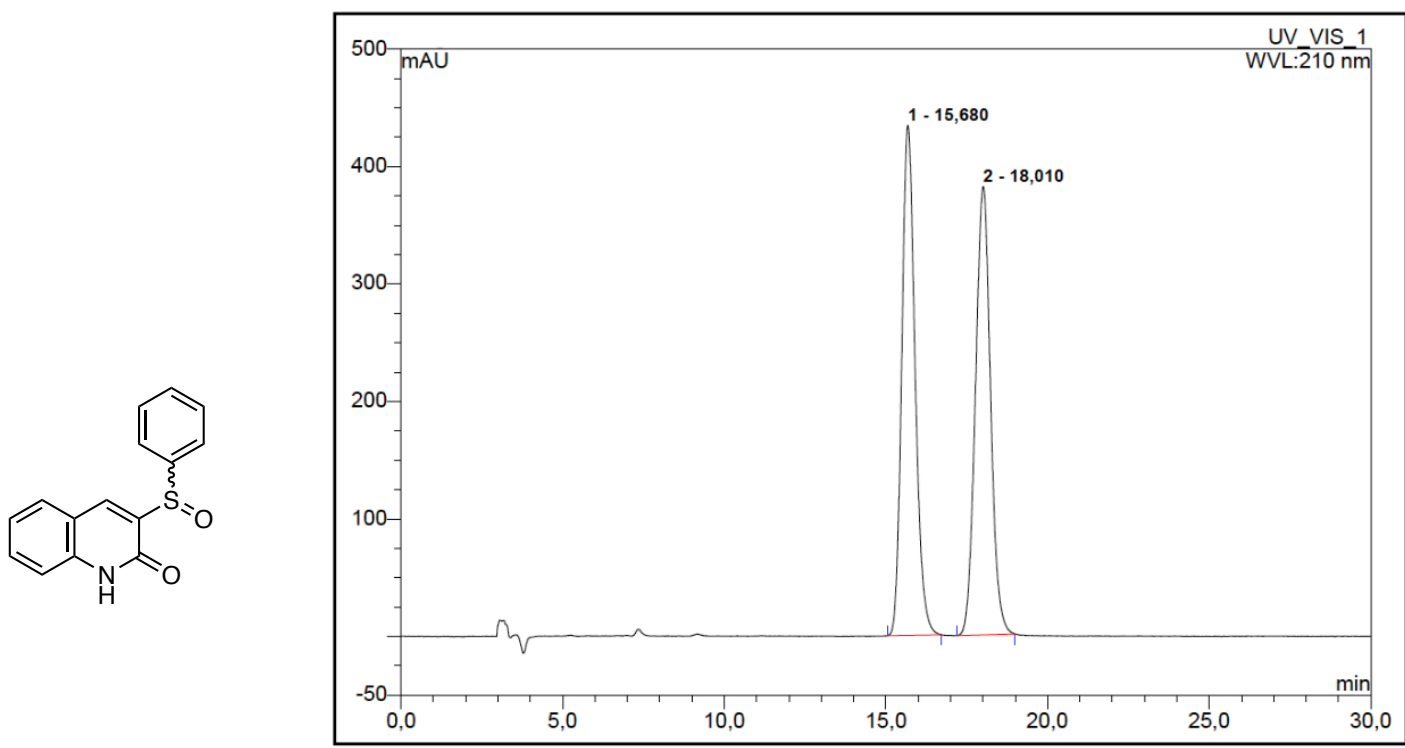

\begin{tabular}{|r|ccccccc|}
\hline No. & $\begin{array}{c}\text { Ret.Time } \\
\text { min }\end{array}$ & Peak Name & $\begin{array}{c}\text { Height } \\
\text { mAU }\end{array}$ & $\begin{array}{c}\text { Area } \\
\text { mAU*min }\end{array}$ & $\begin{array}{c}\text { Rel.Area } \\
\%\end{array}$ & Amount & Type \\
\hline 1 & 15,68 & n.a. & 434,366 & 207,313 & 50,07 & n.a. & BMB \\
2 & 18,01 & n.a. & 381,697 & 206,764 & 49,93 & n.a. & BMB \\
\hline Total: & & & 816,064 & 414,078 & 100,00 & 0,000 & \\
\hline
\end{tabular}<smiles>O=c1[nH]c2ccccc2cc1S(=O)c1ccccc1</smiles>

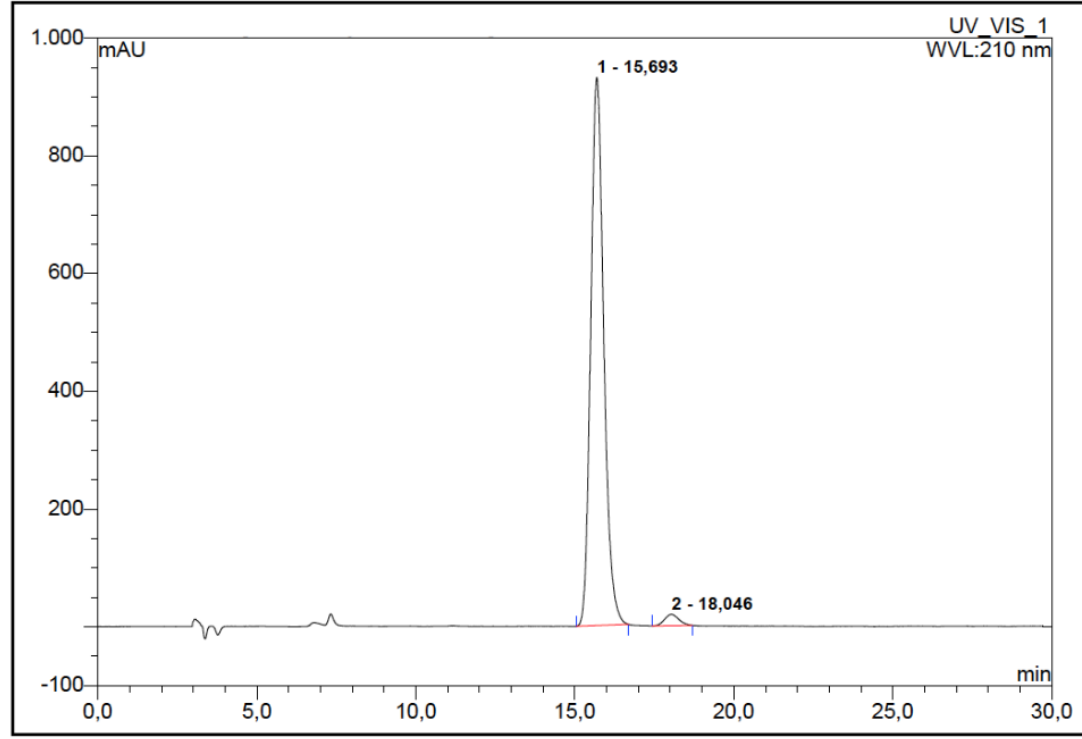

\begin{tabular}{|r|rrrrrrr|}
\hline No. & $\begin{array}{r}\text { Ret.Time } \\
\text { min }\end{array}$ & Peak Name & $\begin{array}{c}\text { Height } \\
\text { mAU }\end{array}$ & $\begin{array}{c}\text { Area } \\
\text { mAU*min }\end{array}$ & $\begin{array}{c}\text { Rel.Area } \\
\%\end{array}$ & Amount & Type \\
\hline 1 & 15,69 & n.a. & 931,109 & 442,280 & 97,82 & n.a. & BMB \\
2 & 18,05 & n.a. & 19,051 & 9,867 & 2,18 & n.a. & BMB \\
\hline Total: & & & 950,161 & 452,147 & 100,00 & 0,000 & \\
\hline
\end{tabular}


Kinetic resolution of $\mathbf{8 a}$

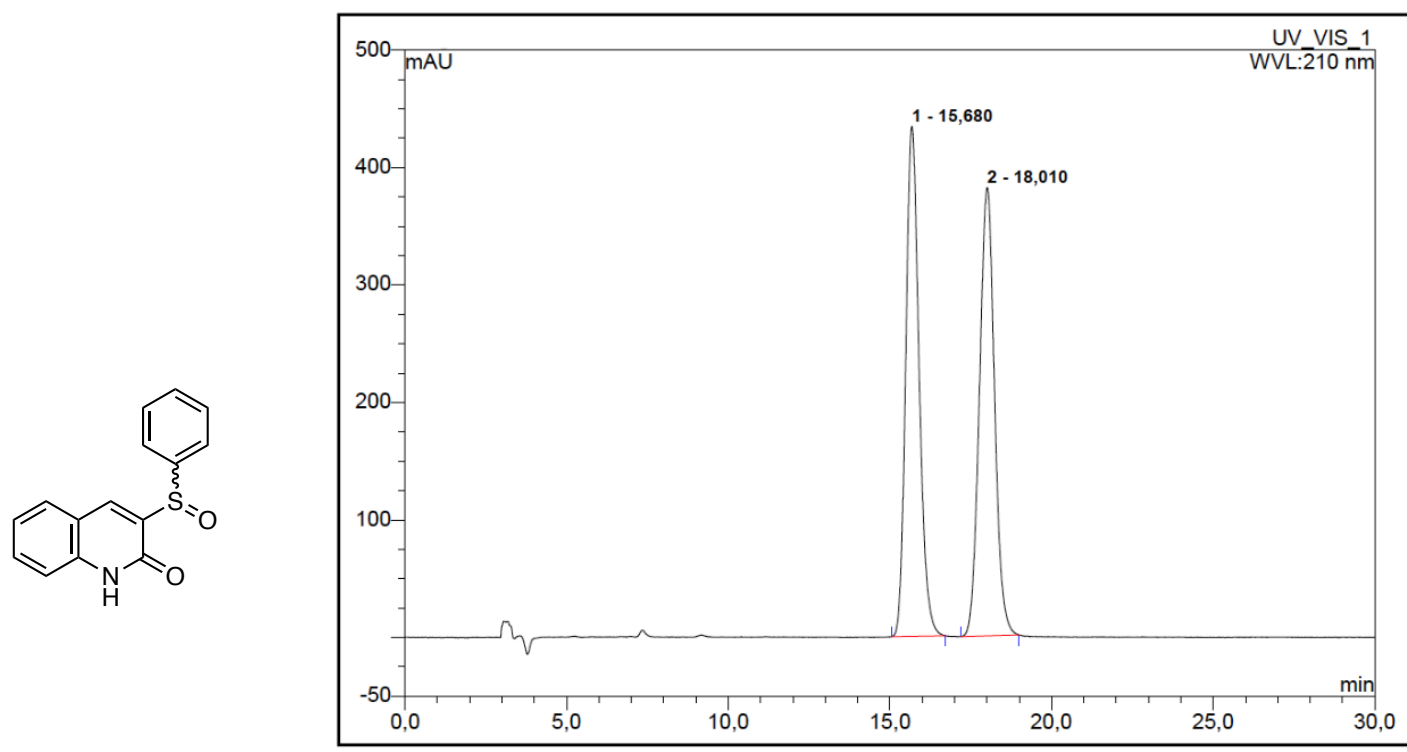

\begin{tabular}{|r|ccccccc|}
\hline No. & $\begin{array}{c}\text { Ret.Time } \\
\text { min }\end{array}$ & Peak Name & $\begin{array}{c}\text { Height } \\
\text { mAU }\end{array}$ & $\begin{array}{c}\text { Area } \\
\text { mAU*min }\end{array}$ & $\begin{array}{c}\text { Rel.Area } \\
\%\end{array}$ & Amount & Type \\
\hline 1 & 15,68 & n.a. & 434,366 & 207,313 & 50,07 & n.a. & BMB \\
2 & 18,01 & n.a. & 381,697 & 206,764 & 49,93 & n.a. & BMB \\
\hline Total: & & & 816,064 & 414,078 & 100,00 & 0,000 & \\
\hline
\end{tabular}

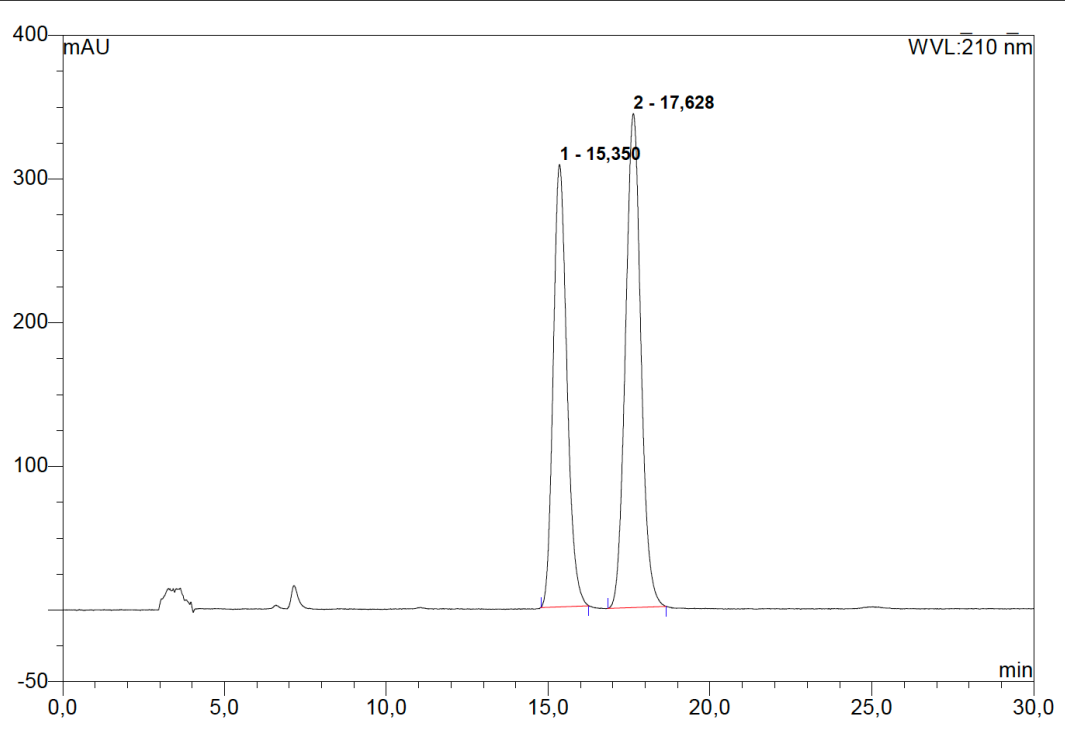

\begin{tabular}{|c|ccccccc|}
\hline No. & $\begin{array}{c}\text { Ret.Time } \\
\text { min }\end{array}$ & Peak Name & $\begin{array}{c}\text { Height } \\
\text { mAU }\end{array}$ & $\begin{array}{c}\text { Area } \\
\text { mAU*min }\end{array}$ & $\begin{array}{c}\text { Rel.Area } \\
\%\end{array}$ & Amount & Type \\
\hline 1 & 15,35 & n.a. & 307,836 & 151,049 & 44,27 & n.a. & BMB \\
2 & 17,63 & n.a. & 343,710 & 190,180 & 55,73 & n.a. & BMB \\
\hline Total: & & & 651,546 & 341,230 & 100,00 & 0,000 & \\
\hline
\end{tabular}



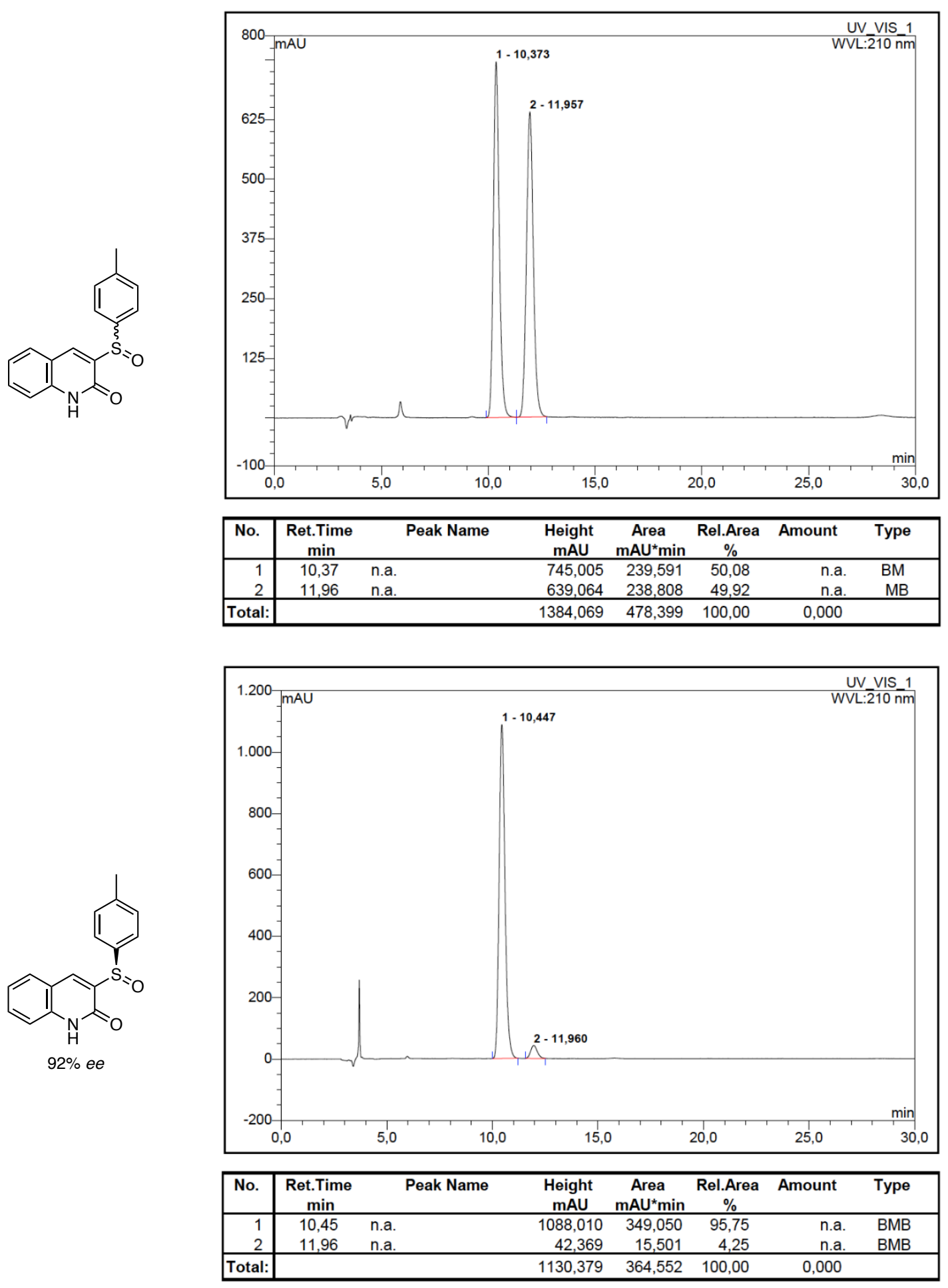

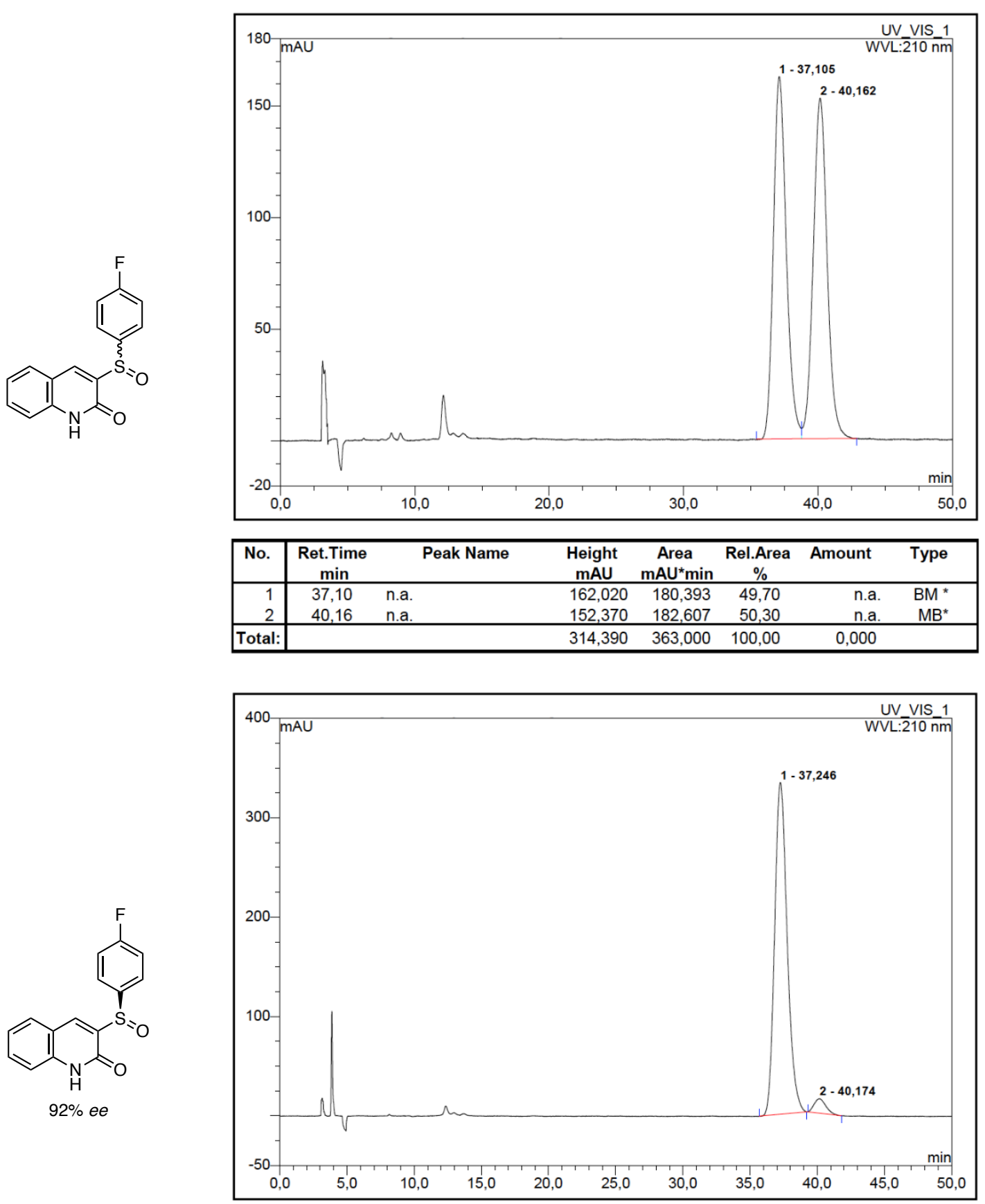

\begin{tabular}{|c|c|c|c|c|c|c|c|}
\hline No. & $\begin{array}{c}\text { Ret.Time } \\
\text { min }\end{array}$ & Peak Name & $\begin{array}{c}\text { Height } \\
\text { mAU }\end{array}$ & $\begin{array}{c}\text { Area } \\
\mathrm{mAU} U^{*} \min \end{array}$ & $\begin{array}{c}\text { Rel.Area } \\
\%\end{array}$ & Amount & Type \\
\hline 1 & 37,25 & n.a. & 333,954 & 361,777 & 96,12 & n.a. & $\mathrm{BMB}^{\star}$ \\
\hline 2 & 40,17 & n.a. & 14,570 & 14,618 & 3,88 & n.a. & $\mathrm{BMB}^{*}$ \\
\hline Total: & & & 348,524 & 376,395 & 100,00 & 0,000 & \\
\hline
\end{tabular}



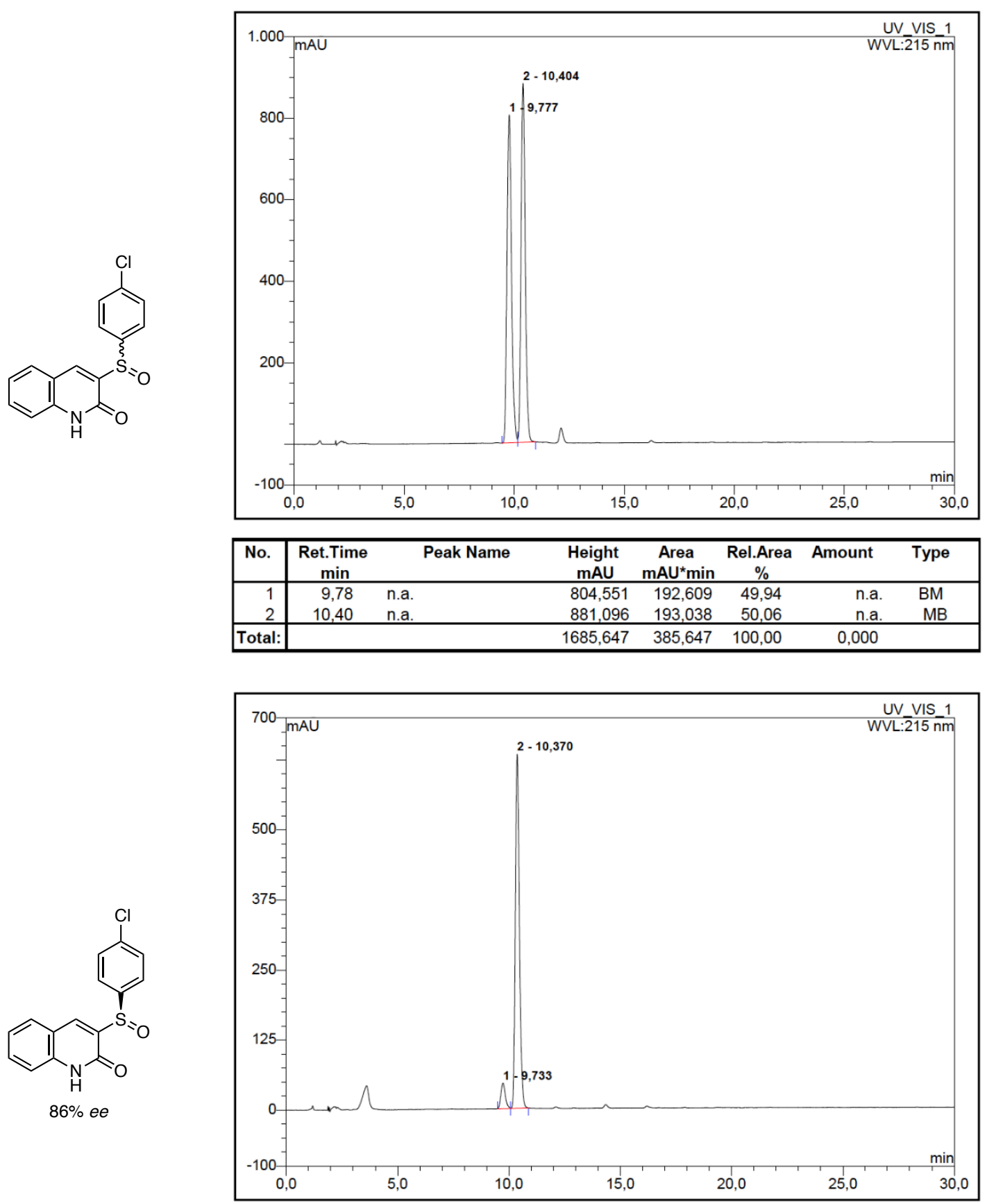

\begin{tabular}{|c|c|c|c|c|c|c|c|}
\hline No. & $\begin{array}{c}\text { Ret.Time } \\
\text { min }\end{array}$ & Peak Name & $\begin{array}{c}\text { Height } \\
\text { mAU }\end{array}$ & $\begin{array}{c}\text { Area } \\
\mathrm{mAU^{* } \operatorname { m i n }}\end{array}$ & $\begin{array}{c}\text { Rel.Area } \\
\%\end{array}$ & Amount & Type \\
\hline 1 & 9,73 & n.a. & 45,326 & 10,484 & 7,21 & n.a. & BM \\
\hline 2 & 10,37 & n.a. & 632,558 & 134,960 & 92,79 & n.a. & $\mathrm{MB}$ \\
\hline Total: & & & 677,883 & 145,445 & 100,00 & 0,000 & \\
\hline
\end{tabular}




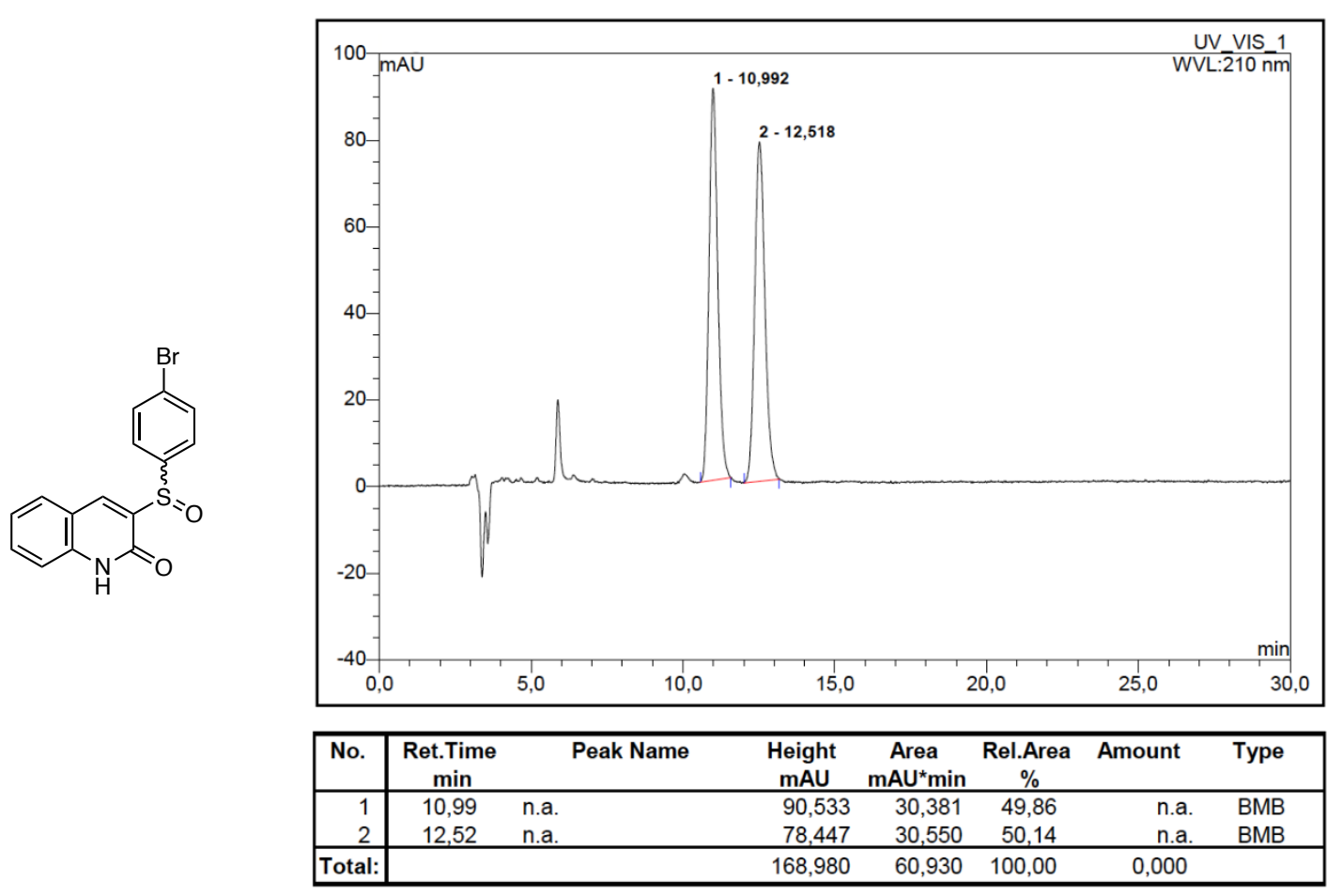<smiles>O=c1[nH]c2ccccc2cc1S(=O)c1ccc(Br)cc1</smiles>

$88 \%$ ee

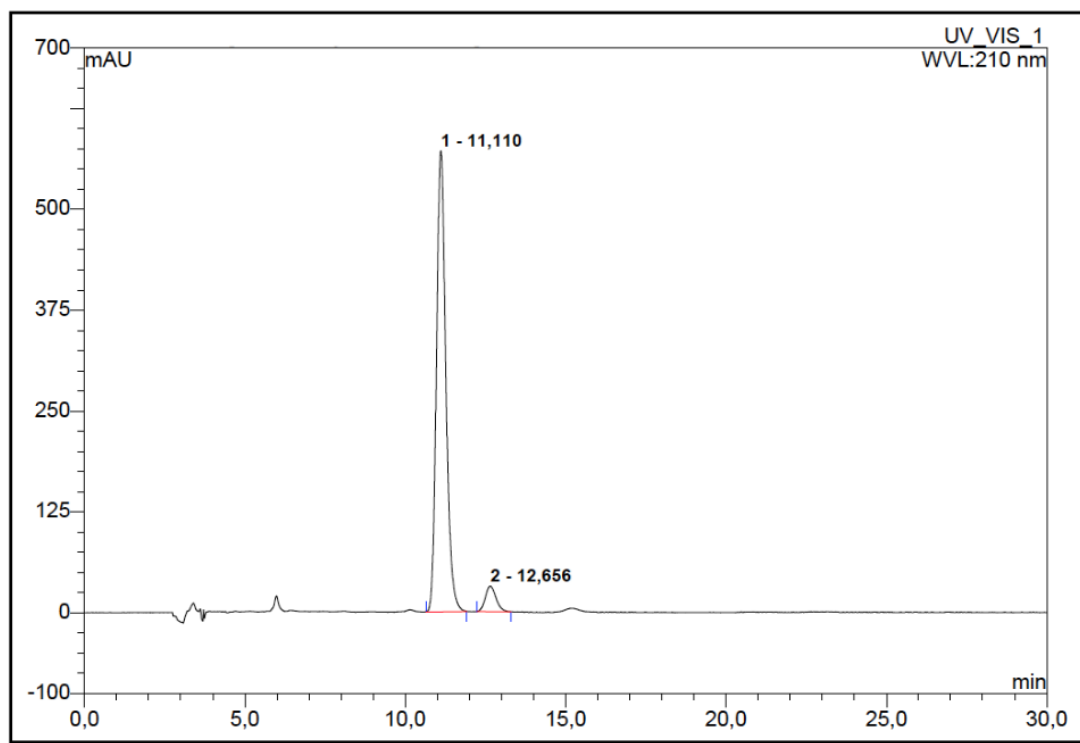

\begin{tabular}{|r|ccrrrrr|}
\hline No. & $\begin{array}{c}\text { Ret.Time } \\
\text { min }\end{array}$ & Peak Name & $\begin{array}{c}\text { Height } \\
\text { mAU }\end{array}$ & $\begin{array}{c}\text { Area } \\
\text { mAU*min }\end{array}$ & $\begin{array}{r}\text { Rel.Area } \\
\%\end{array}$ & Amount & Type \\
\hline 1 & 11,11 & n.a. & 571,415 & 193,930 & 94,15 & n.a. & BMB \\
2 & 12,66 & n.a. & 31,453 & 12,046 & 5,85 & n.a. & BMB $^{*}$ \\
\hline Total: & & & 602,868 & 205,976 & 100,00 & 0,000 & \\
\hline
\end{tabular}



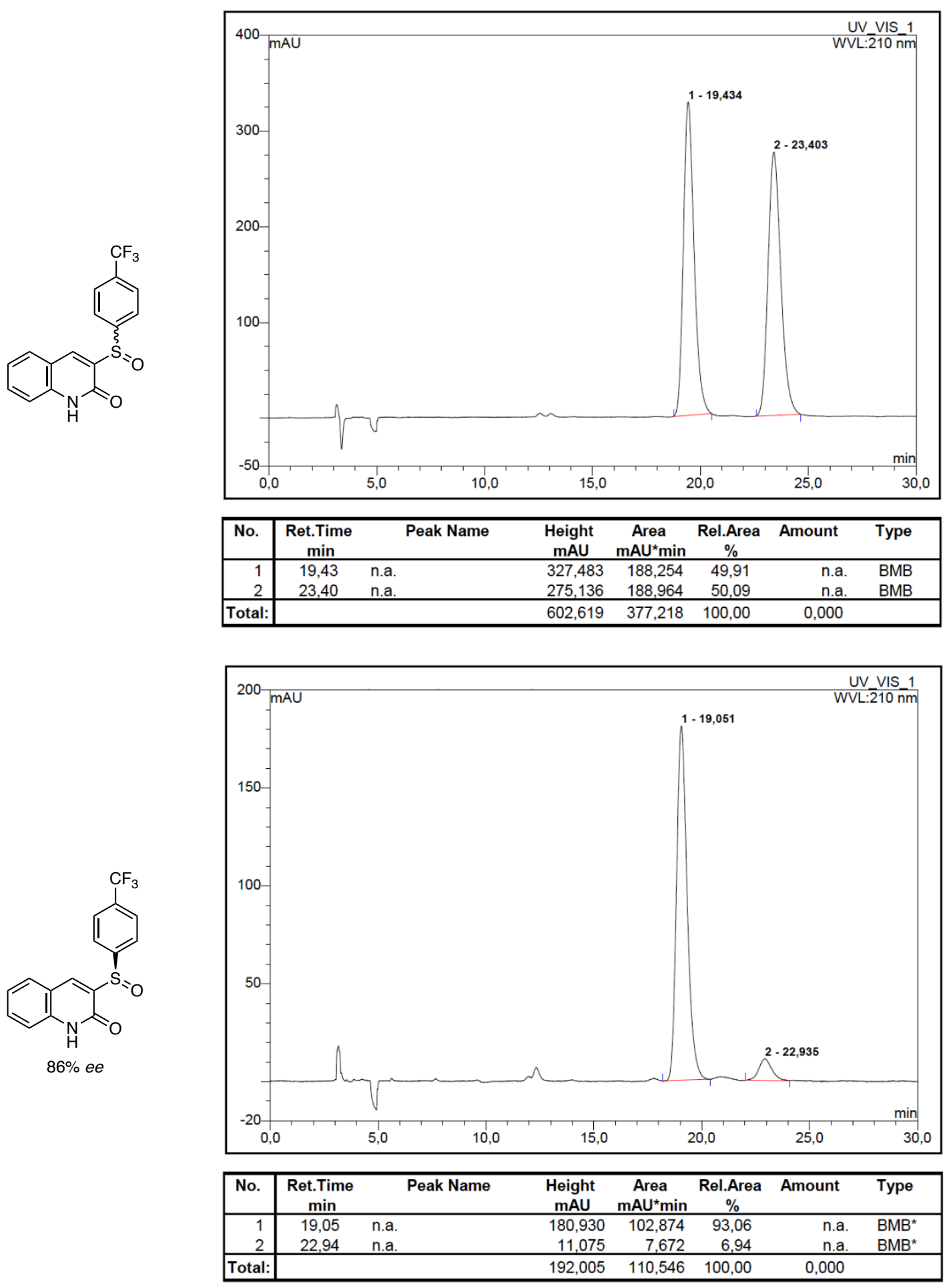

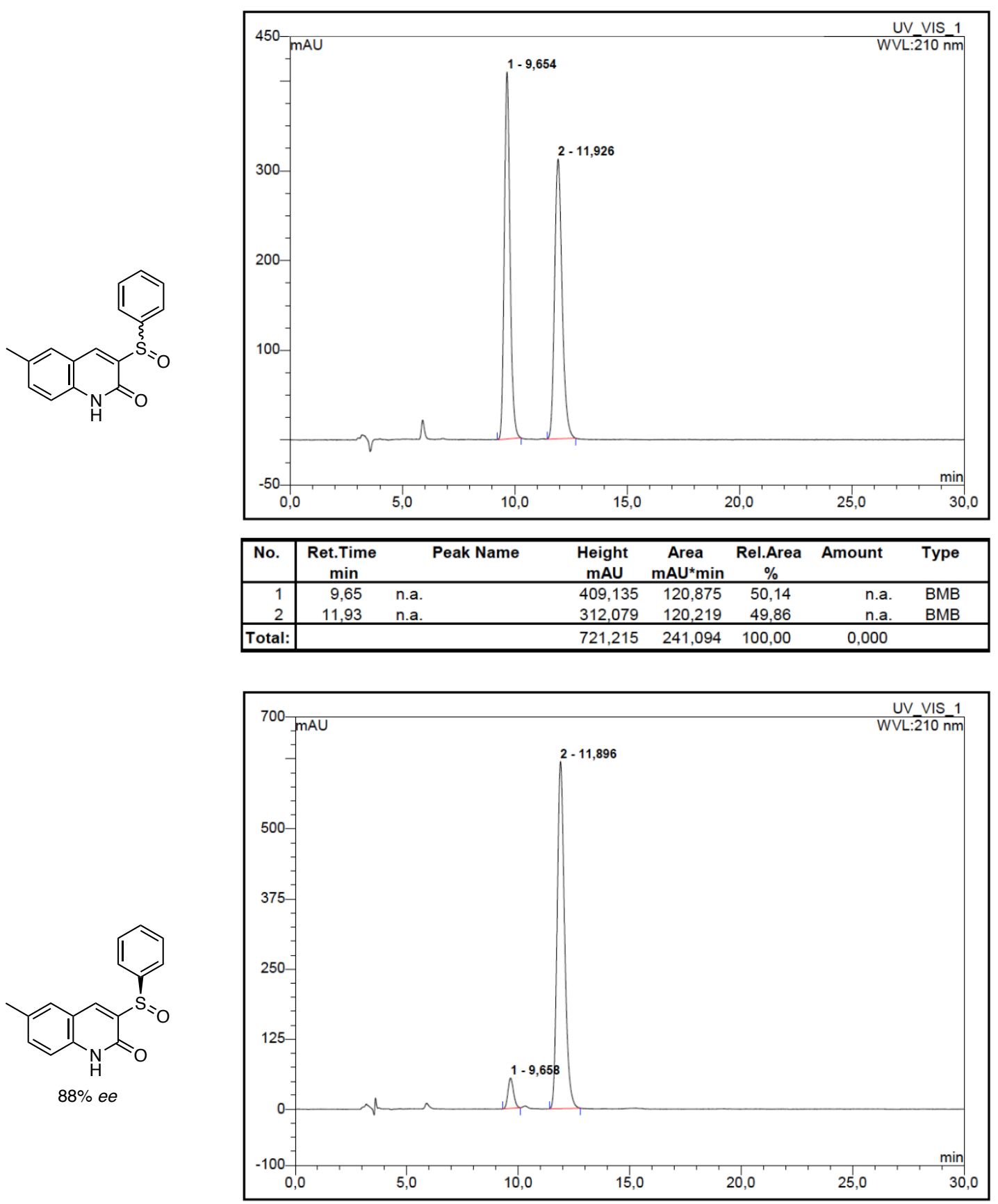

\begin{tabular}{|r|rrrrrrr|}
\hline No. & $\begin{array}{c}\text { Ret.Time } \\
\text { min }\end{array}$ & Peak Name & $\begin{array}{c}\text { Height } \\
\text { mAU }\end{array}$ & $\begin{array}{c}\text { Area } \\
\text { mAU*min }\end{array}$ & $\begin{array}{r}\text { Rel.Area } \\
\%\end{array}$ & Amount & Type \\
\hline 1 & 9,66 & n.a. & 54,146 & 15,628 & 6,16 & n.a. & BMB \\
2 & 11,90 & n.a. & 618,699 & 237,871 & 93,84 & n.a. & BMB \\
\hline Total: & & & 672,845 & 253,500 & 100,00 & 0,000 & \\
\hline
\end{tabular}



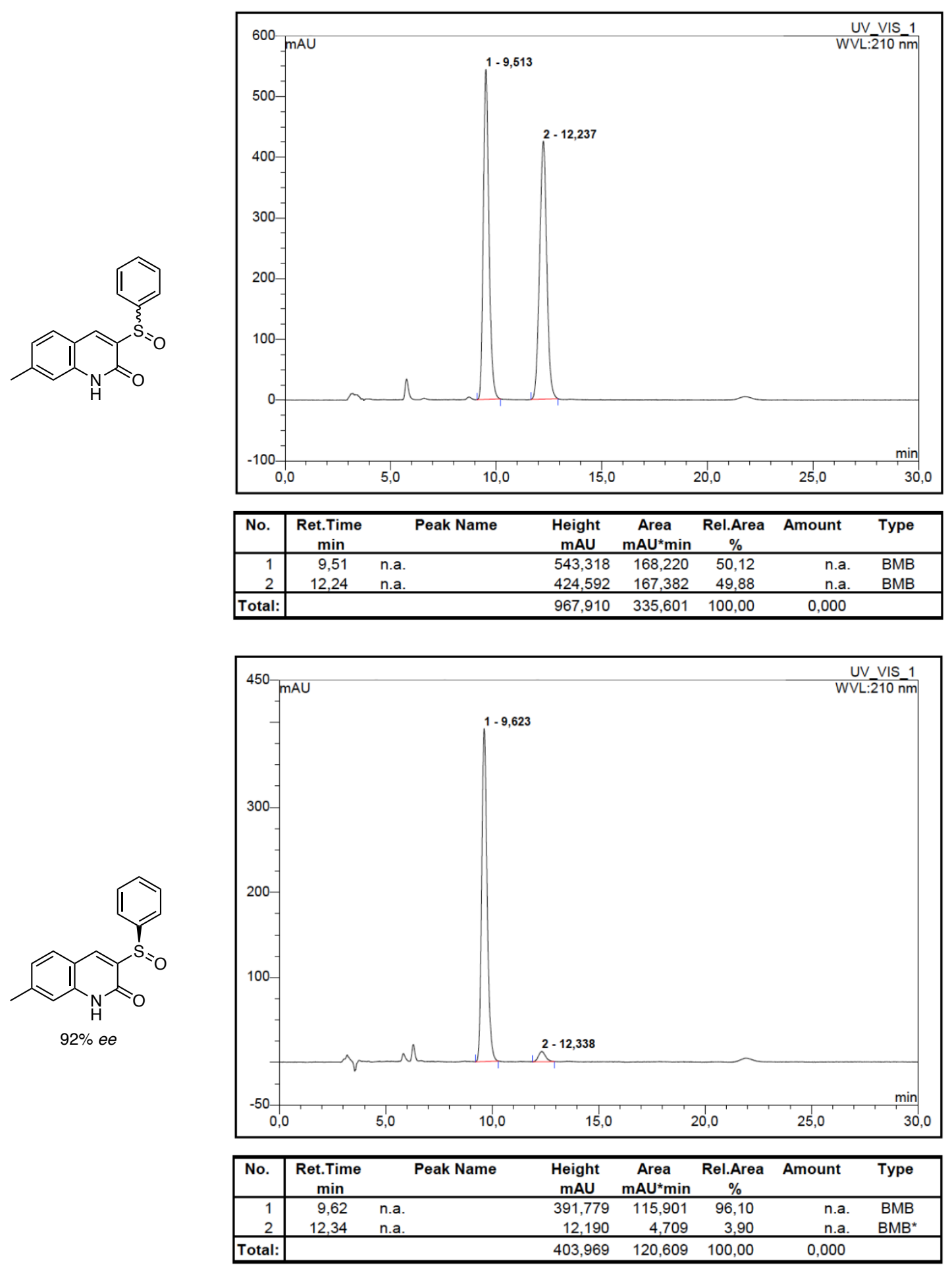

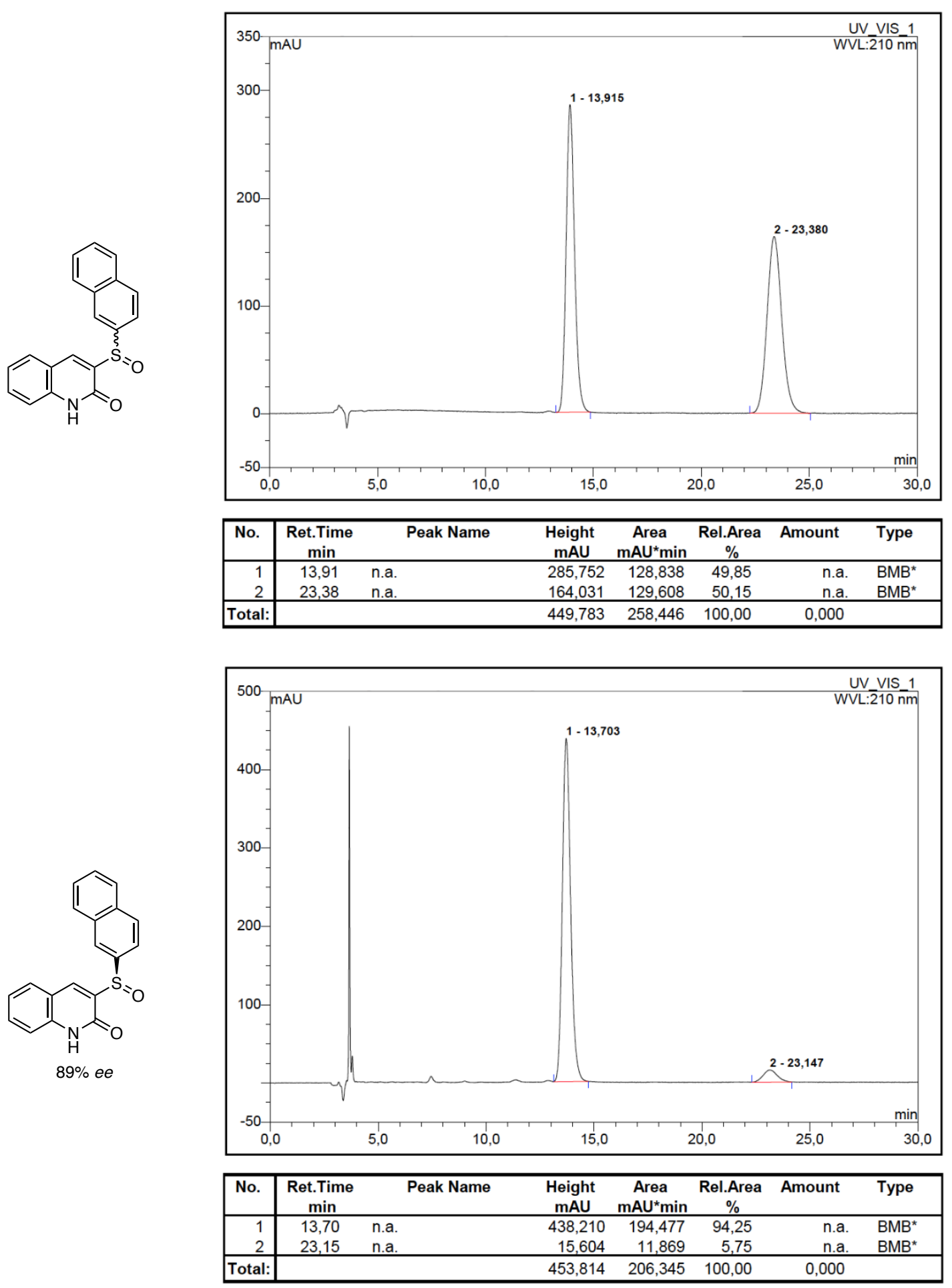

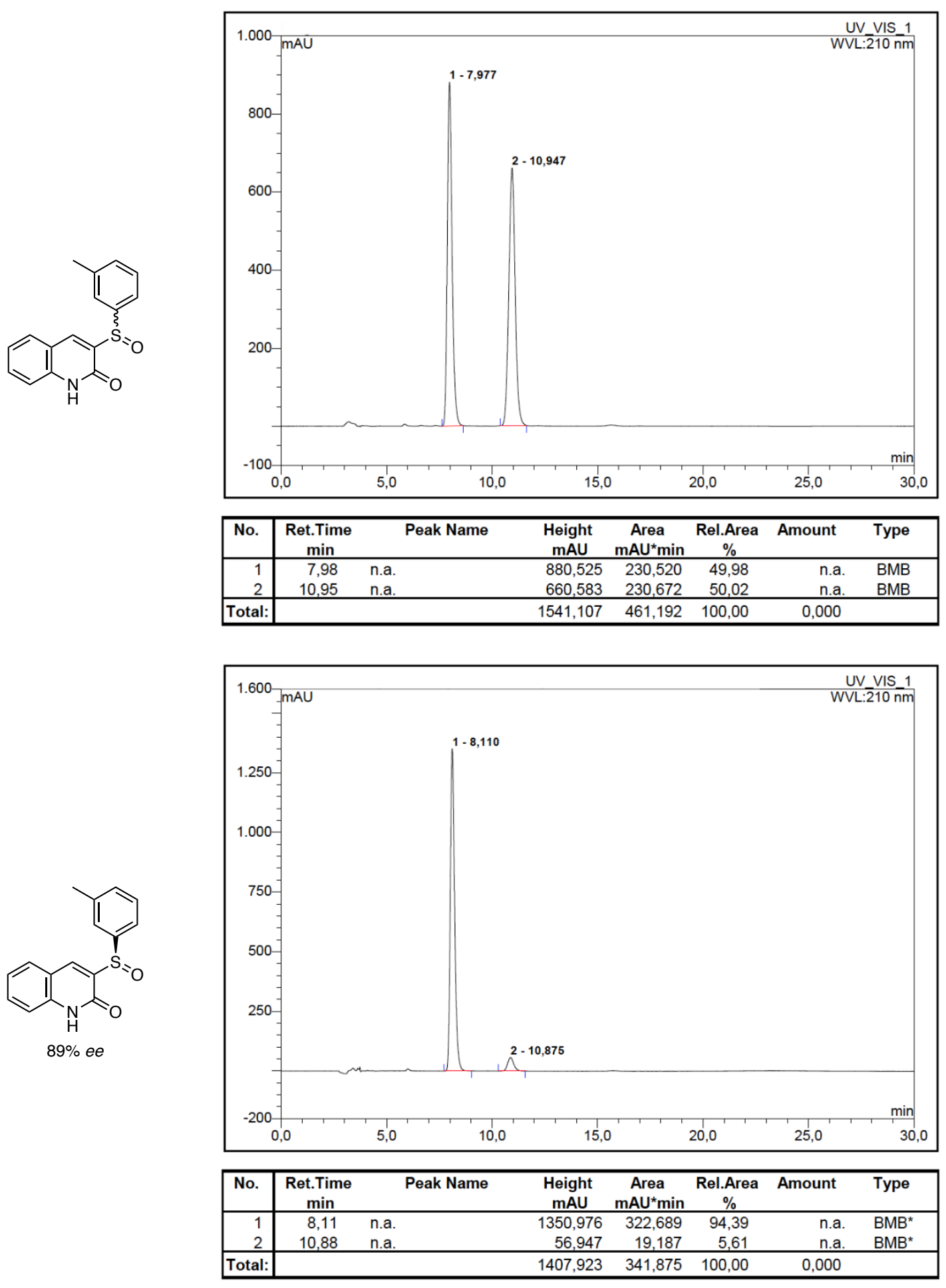

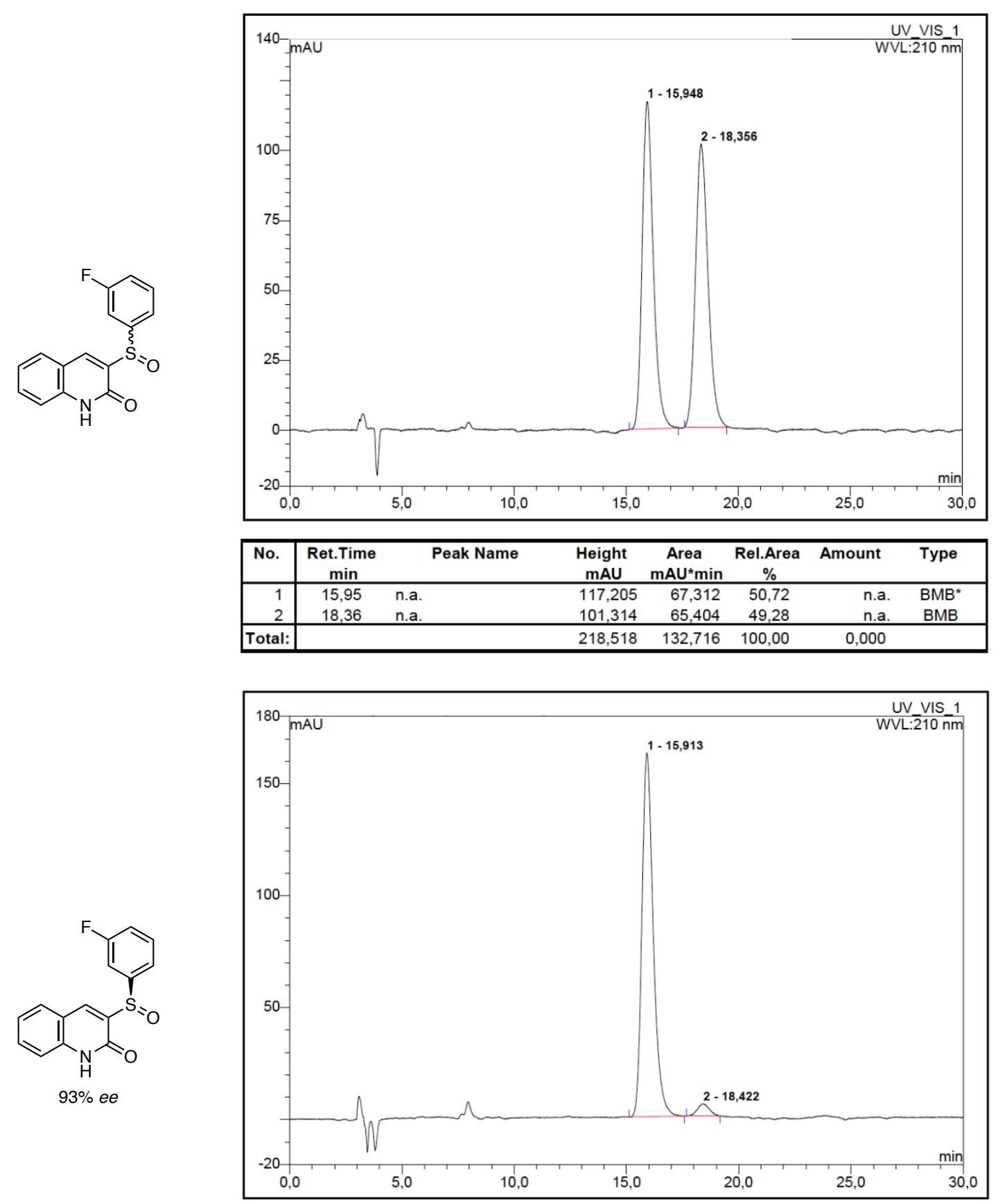

\begin{tabular}{|r|rrrrrrr|}
\hline No. & $\begin{array}{r}\text { Ret.Time } \\
\text { min }\end{array}$ & Peak Name & $\begin{array}{c}\text { Height } \\
\text { mAU }\end{array}$ & $\begin{array}{r}\text { Area } \\
\text { mAU*min }\end{array}$ & $\begin{array}{r}\text { Rel.Area } \\
\%\end{array}$ & Amount & Type \\
\hline 1 & 15,91 & n.a. & 162,338 & 94,559 & 96,55 & n.a. & BMB $^{*}$ \\
2 & 18,42 & n.a. & 5,470 & 3,381 & 3,45 & n.a. & BMB $^{*}$ \\
\hline Total: & & & 167,808 & 97,939 & 100,00 & 0,000 & \\
\hline
\end{tabular}


3.2.12. (R)-3-(o-Tolylsulfinyl)-2-quinolone (81)
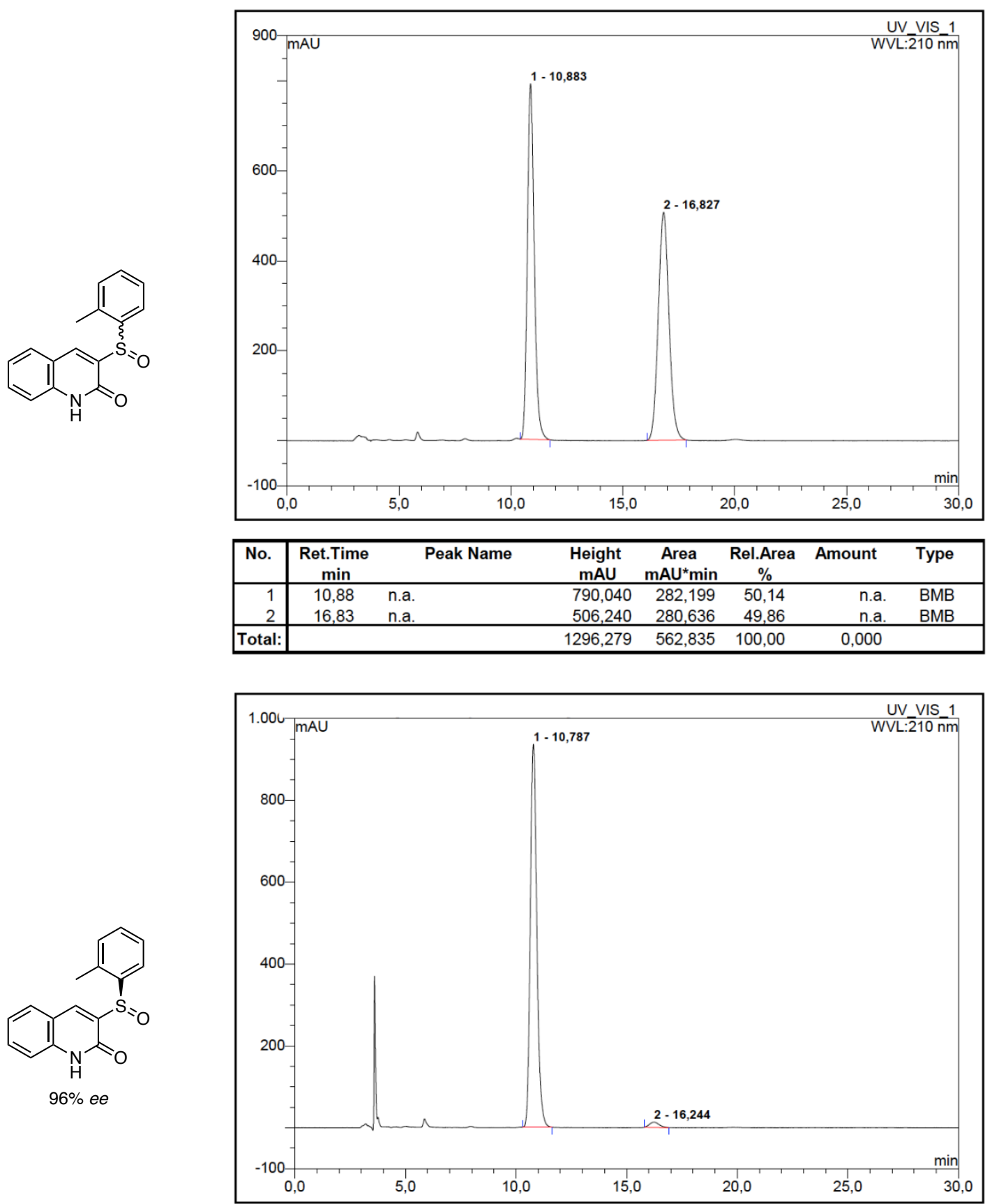

\begin{tabular}{|r|rrrrrrr|}
\hline No. & $\begin{array}{r}\text { Ret.Time } \\
\text { min }\end{array}$ & Peak Name & $\begin{array}{c}\text { Height } \\
\text { mAU }\end{array}$ & $\begin{array}{r}\text { Area } \\
\text { mAU*min }\end{array}$ & $\begin{array}{r}\text { Rel.Area } \\
\%\end{array}$ & Amount & Type \\
& 10,79 & n.a. & 935,953 & 318,834 & 98,10 & n.a. & BMB \\
\hline 1 & 16,24 & n.a. & 12,851 & 6,187 & 1,90 & n.a. & BMB $^{*}$ \\
\hline Total: & & & 948,804 & 325,020 & 100,00 & 0,000 & \\
\hline
\end{tabular}


<smiles>CCc1ccccc1C(=O)c1cc2ccccc2[nH]c1=O</smiles>

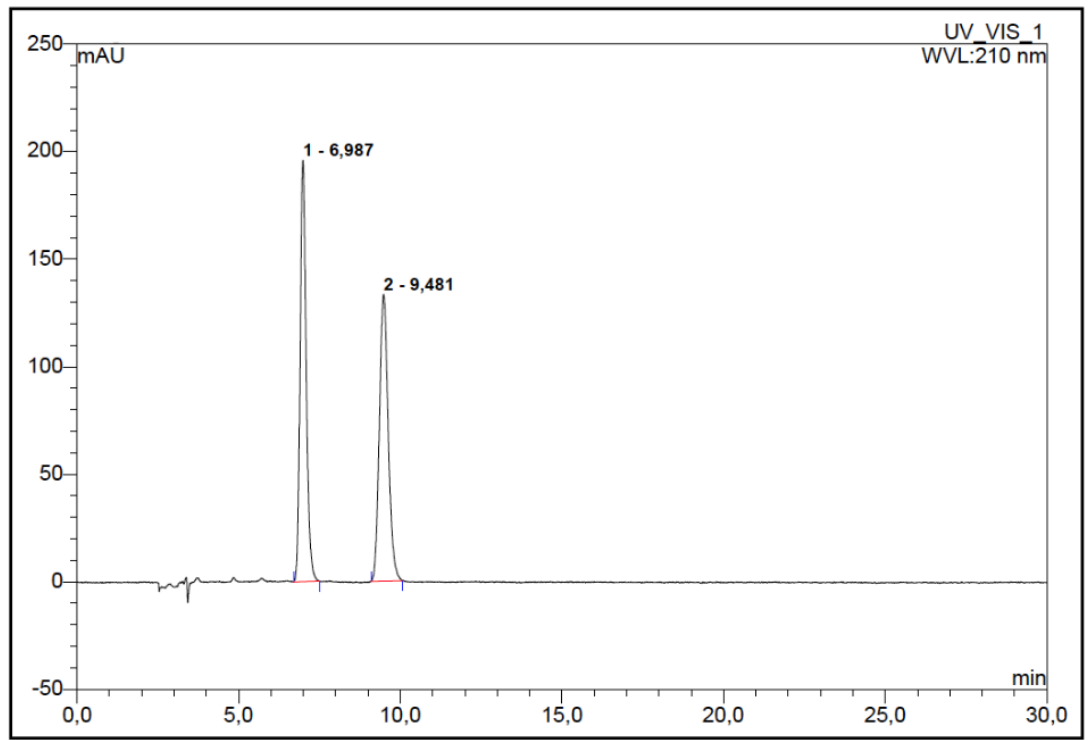

\begin{tabular}{|r|ccrrrrr|}
\hline No. & $\begin{array}{c}\text { Ret.Time } \\
\text { min }\end{array}$ & Peak Name & $\begin{array}{c}\text { Height } \\
\text { mAU }\end{array}$ & $\begin{array}{c}\text { Area } \\
\text { mAU*min }\end{array}$ & $\begin{array}{r}\text { Rel.Area } \\
\%\end{array}$ & Amount & Type \\
\hline 1 & 6,99 & n.a. & 195,917 & 43,131 & 50,39 & n.a. & BMB \\
2 & 9,48 & n.a. & 133,278 & 42,466 & 49,61 & n.a. & BMB \\
\hline Total: & & & 329,195 & 85,597 & 100,00 & 0,000 & \\
\hline
\end{tabular}<smiles>CCc1ccccc1S(=O)(=O)c1cc2ccccc2[nH]c1=O</smiles>

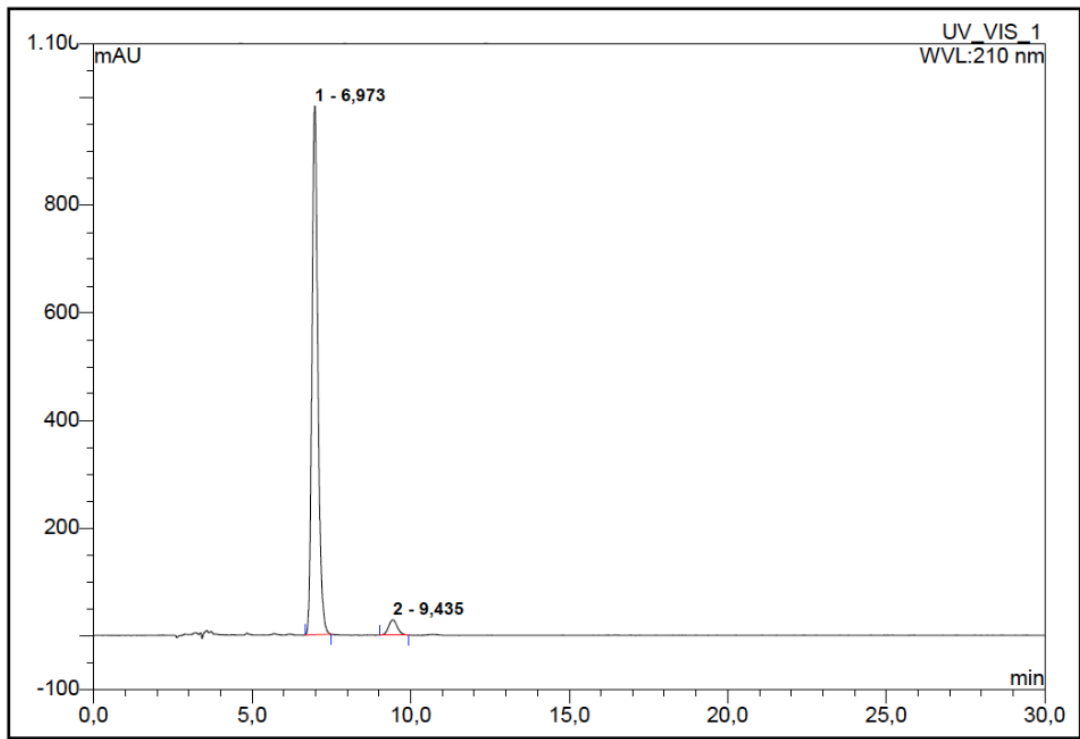

\begin{tabular}{|c|c|c|c|c|c|c|c|}
\hline No. & $\begin{array}{c}\text { Ret.Time } \\
\text { min }\end{array}$ & Peak Name & $\begin{array}{c}\text { Height } \\
\text { mAU }\end{array}$ & $\begin{array}{c}\text { Area } \\
\text { mAU*min }\end{array}$ & $\begin{array}{c}\text { Rel.Area } \\
\%\end{array}$ & Amount & Type \\
\hline 1 & 6,97 & n.a. & 983,624 & 216,127 & 96,00 & n.a. & BMB \\
\hline 2 & 9,44 & n.a. & 28,545 & 8,999 & 4,00 & n.a. & $\mathrm{BMB}^{*}$ \\
\hline Total: & & & 1012,169 & 225,127 & 100,00 & 0,000 & \\
\hline
\end{tabular}



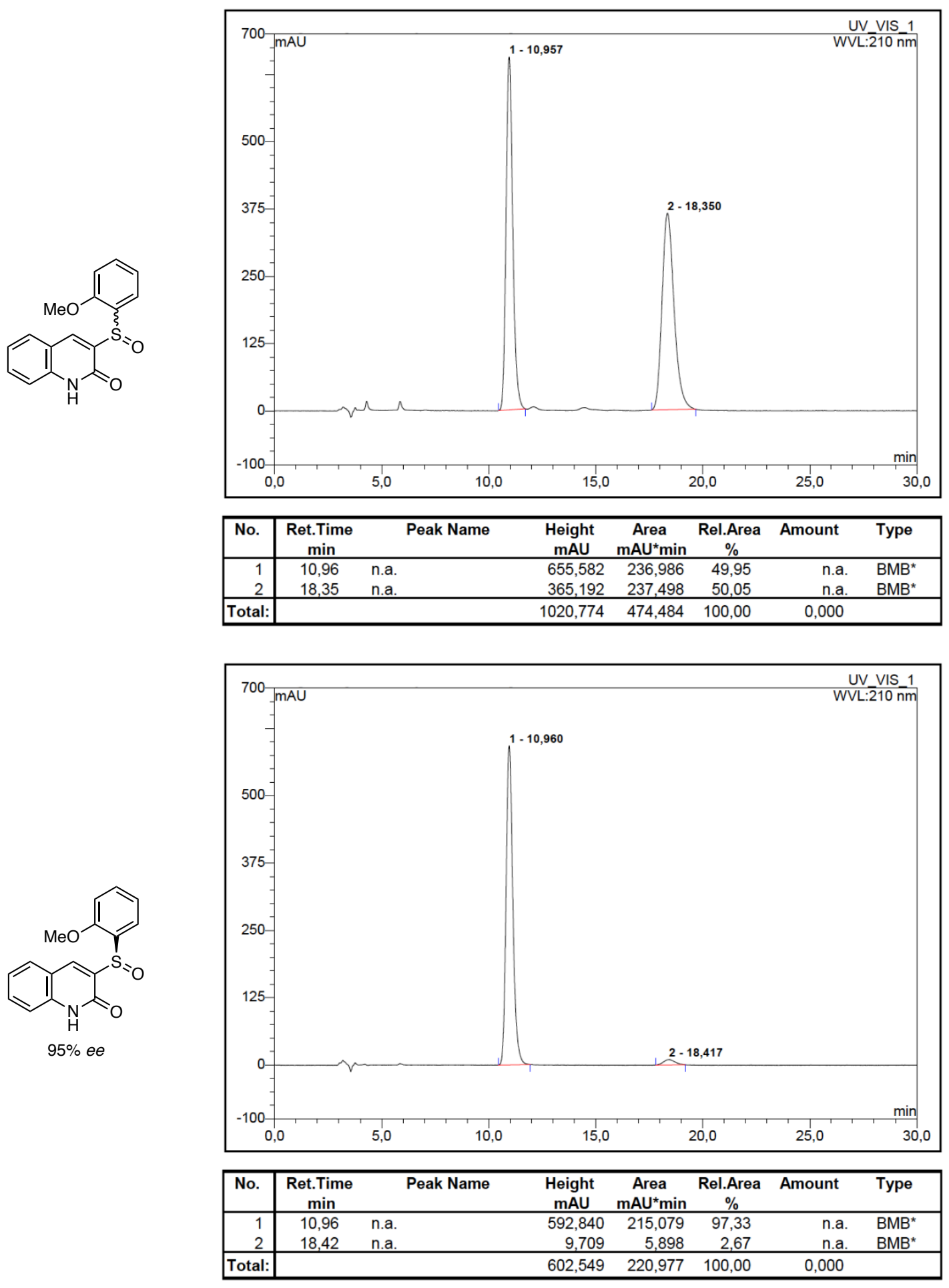
3.2.15. (R)-3-((2,6-Dimethylphenyl)sulfinyl)-2-quinolone (80)<smiles>Cc1cccc(C)c1S(=O)c1cc2ccccc2[nH]c1=O</smiles>

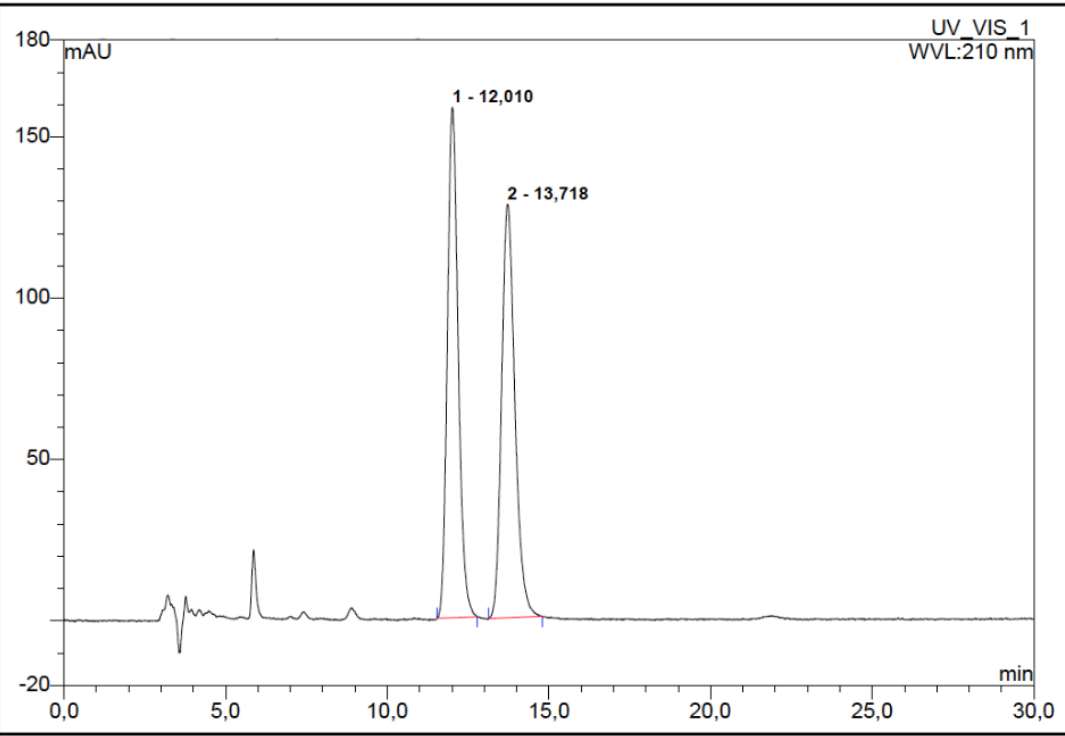

\begin{tabular}{|r|ccrrrrr|}
\hline No. & $\begin{array}{c}\text { Ret.Time } \\
\text { min }\end{array}$ & Peak Name & $\begin{array}{c}\text { Height } \\
\text { mAU }\end{array}$ & $\begin{array}{r}\text { Area } \\
\text { mAU*min }\end{array}$ & $\begin{array}{r}\text { Rel.Area } \\
\%\end{array}$ & Amount & Type \\
\hline 1 & 12,01 & n.a. & 158,217 & 61,453 & 50,19 & n.a. & BMB $^{*}$ \\
2 & 13,72 & n.a. & 128,181 & 60,988 & 49,81 & n.a. & BMB $^{\star}$ \\
\hline Total: & & & 286,398 & 122,442 & 100,00 & 0,000 & \\
\hline
\end{tabular}<smiles>Cc1cccc(C)c1S(=O)c1cc2ccccc2[nH]c1=O</smiles>

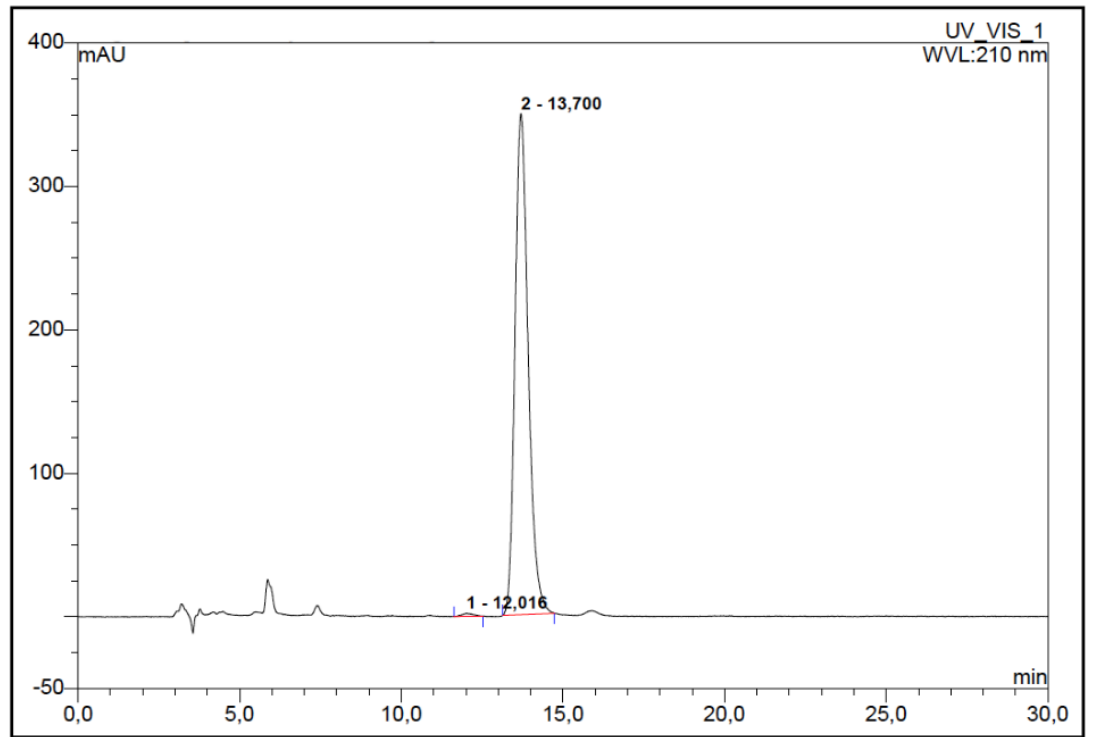

\begin{tabular}{|r|ccrrrrr|}
\hline No. & $\begin{array}{c}\text { Ret.Time } \\
\text { min }\end{array}$ & Peak Name & $\begin{array}{c}\text { Height } \\
\text { mAU }\end{array}$ & $\begin{array}{r}\text { Area } \\
\text { mAU*min }\end{array}$ & $\begin{array}{r}\text { Rel.Area } \\
\%\end{array}$ & Amount & Type \\
\hline 1 & 12,02 & n.a. & 2,177 & 0,808 & 0,49 & n.a. & BMB $^{*}$ \\
2 & 13,70 & n.a. & 349,364 & 165,457 & 99,51 & n.a. & BMB $^{*}$ \\
\hline Total: & & & 351,541 & 166,265 & 100,00 & 0,000 & \\
\hline
\end{tabular}


3.2.16. (R)-3-((2,3,5,6-Tetrafluorophenyl)sulfinyl)-2-quinolone (8p)
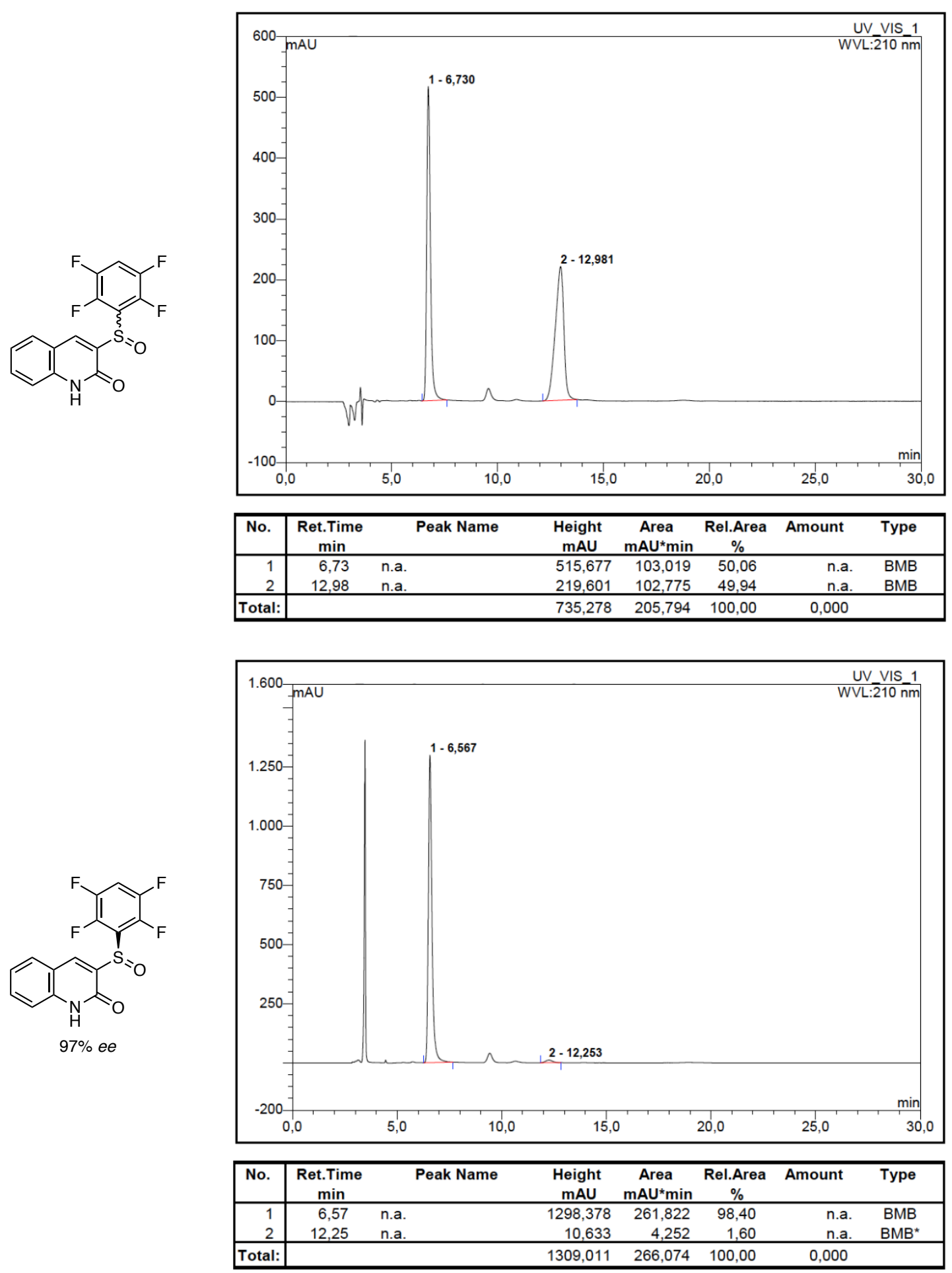
<smiles>Cn1c(=O)c(S(=O)c2ccccc2)cc2ccccc21</smiles>

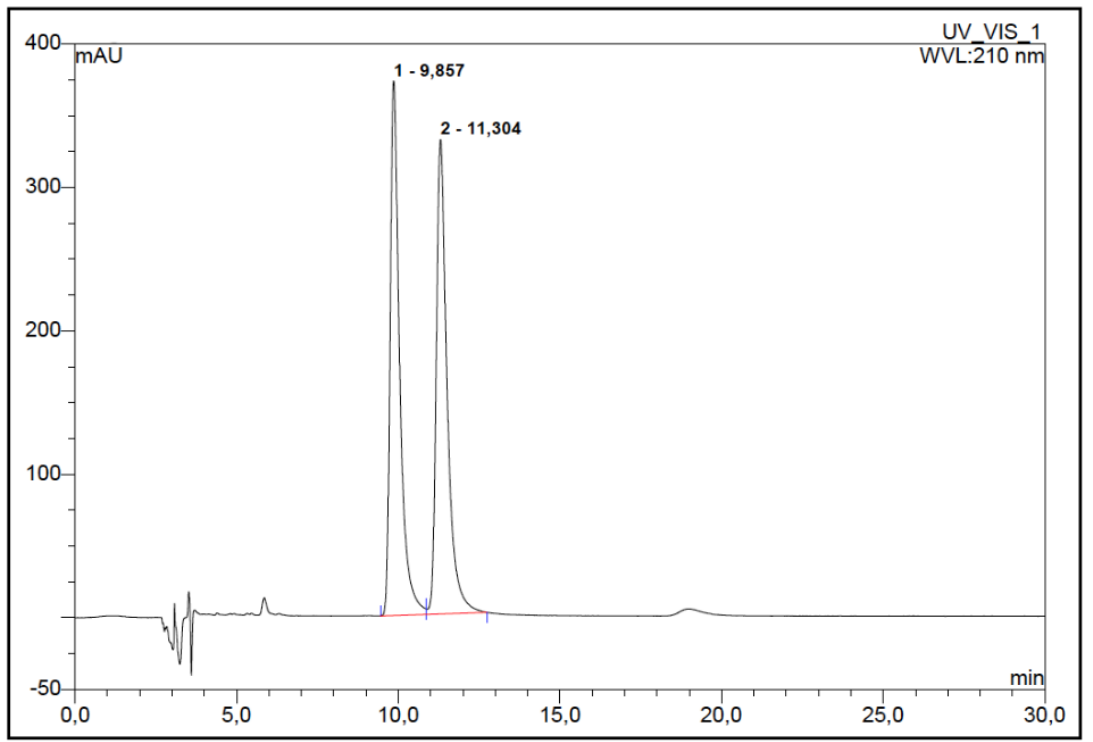

\begin{tabular}{|r|cccrccc|}
\hline No. & $\begin{array}{c}\text { Ret.Time } \\
\text { min }\end{array}$ & Peak Name & $\begin{array}{c}\text { Height } \\
\text { mAU }\end{array}$ & $\begin{array}{r}\text { Area } \\
\text { mAU*min }\end{array}$ & $\begin{array}{c}\text { Rel.Area } \\
\%\end{array}$ & Amount & Type \\
\hline 1 & 9,86 & n.a. & 372,862 & 127,845 & 49,77 & n.a. & BM \\
2 & 11,30 & n.a. & 330,909 & 129,014 & 50,23 & n.a. & MB \\
\hline Total: & & & 703,772 & 256,859 & 100,00 & 0,000 & \\
\hline
\end{tabular}<smiles>O=c1c(S(=O)c2ccccc2)cc2ccccc2n([O-])c1=O</smiles>

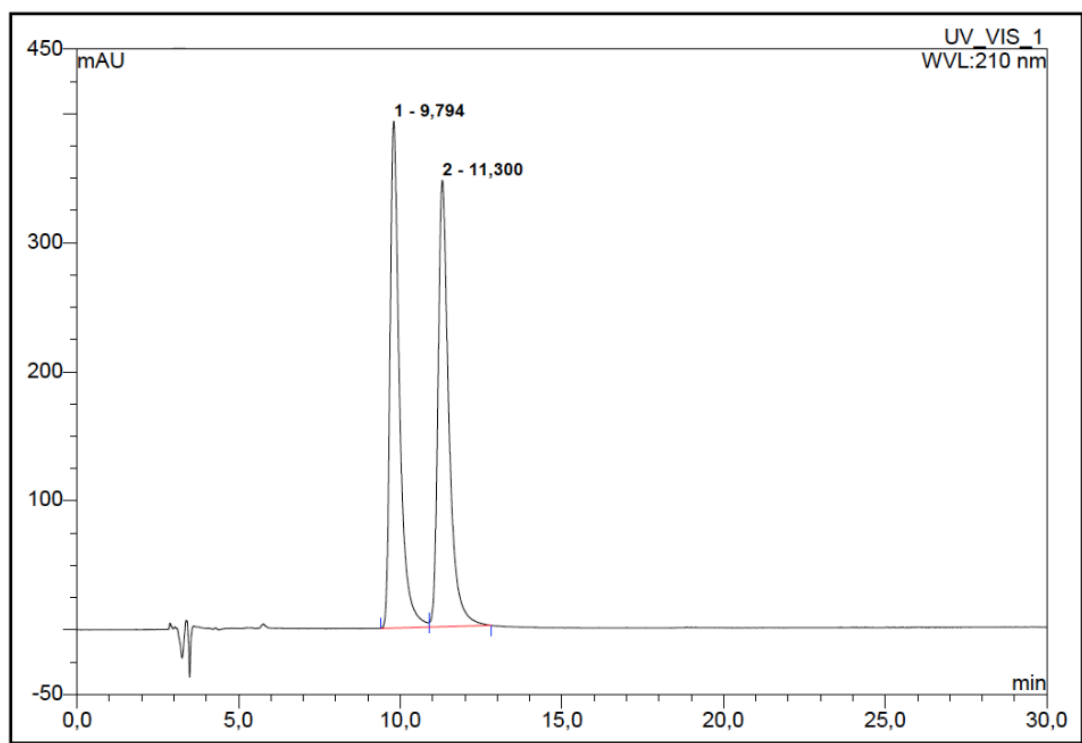

\begin{tabular}{|c|c|c|c|c|c|c|c|}
\hline No. & $\begin{array}{c}\text { Ret.Time } \\
\text { min }\end{array}$ & Peak Name & $\begin{array}{c}\text { Height } \\
\text { mAU }\end{array}$ & $\begin{array}{c}\text { Area } \\
\mathrm{mAU}{ }^{*} \min \end{array}$ & $\begin{array}{c}\text { Rel.Area } \\
\%\end{array}$ & Amount & Type \\
\hline 1 & 9,79 & n.a. & 392,747 & 134,266 & 49,82 & n.a. & $\mathrm{BM}$ \\
\hline 2 & 11,30 & n.a. & 345,956 & 135,254 & 50,18 & n.a. & $\mathrm{MB}$ \\
\hline Total: & & & 738,703 & 269,520 & 100,00 & 0,000 & \\
\hline
\end{tabular}



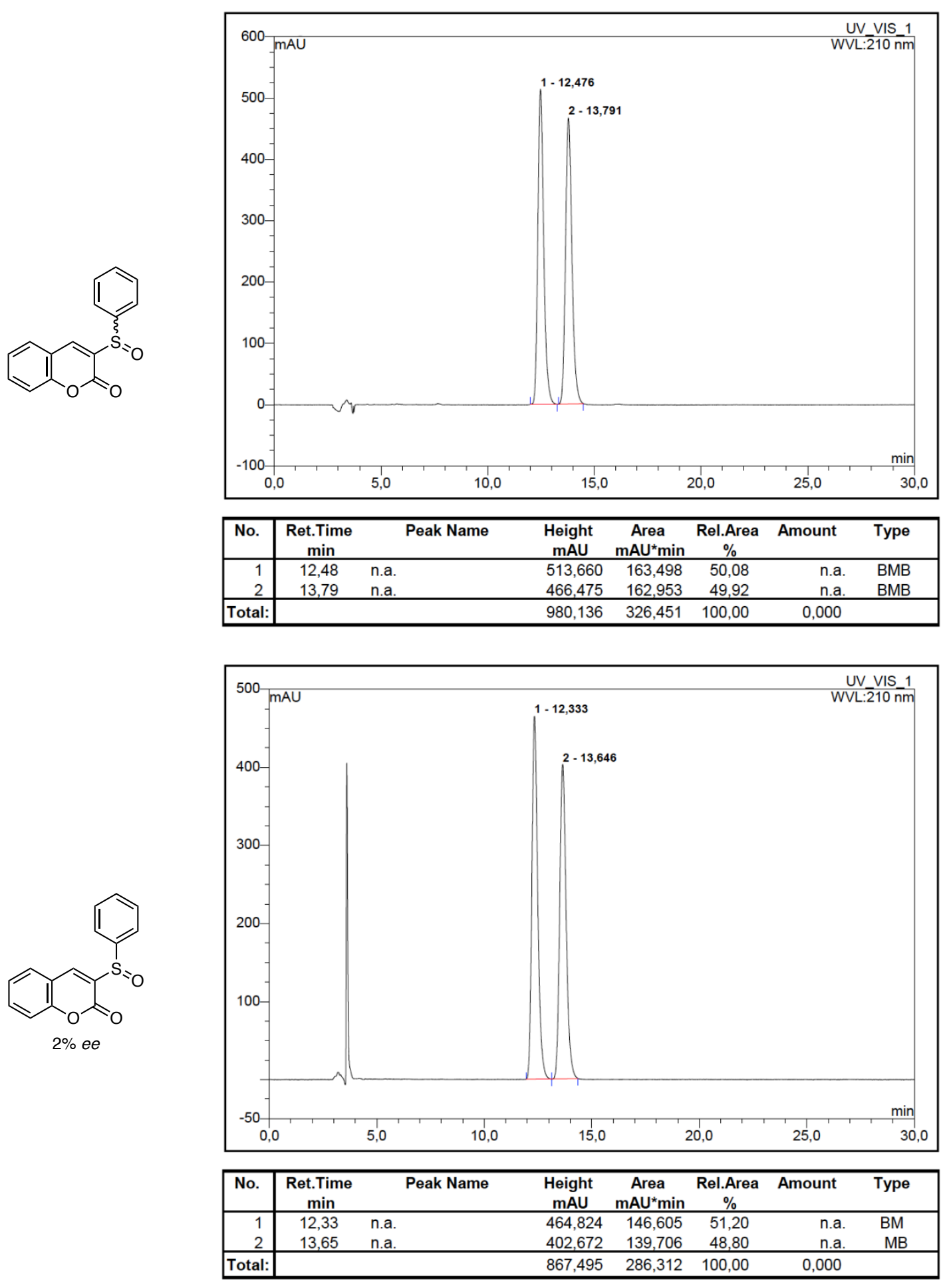

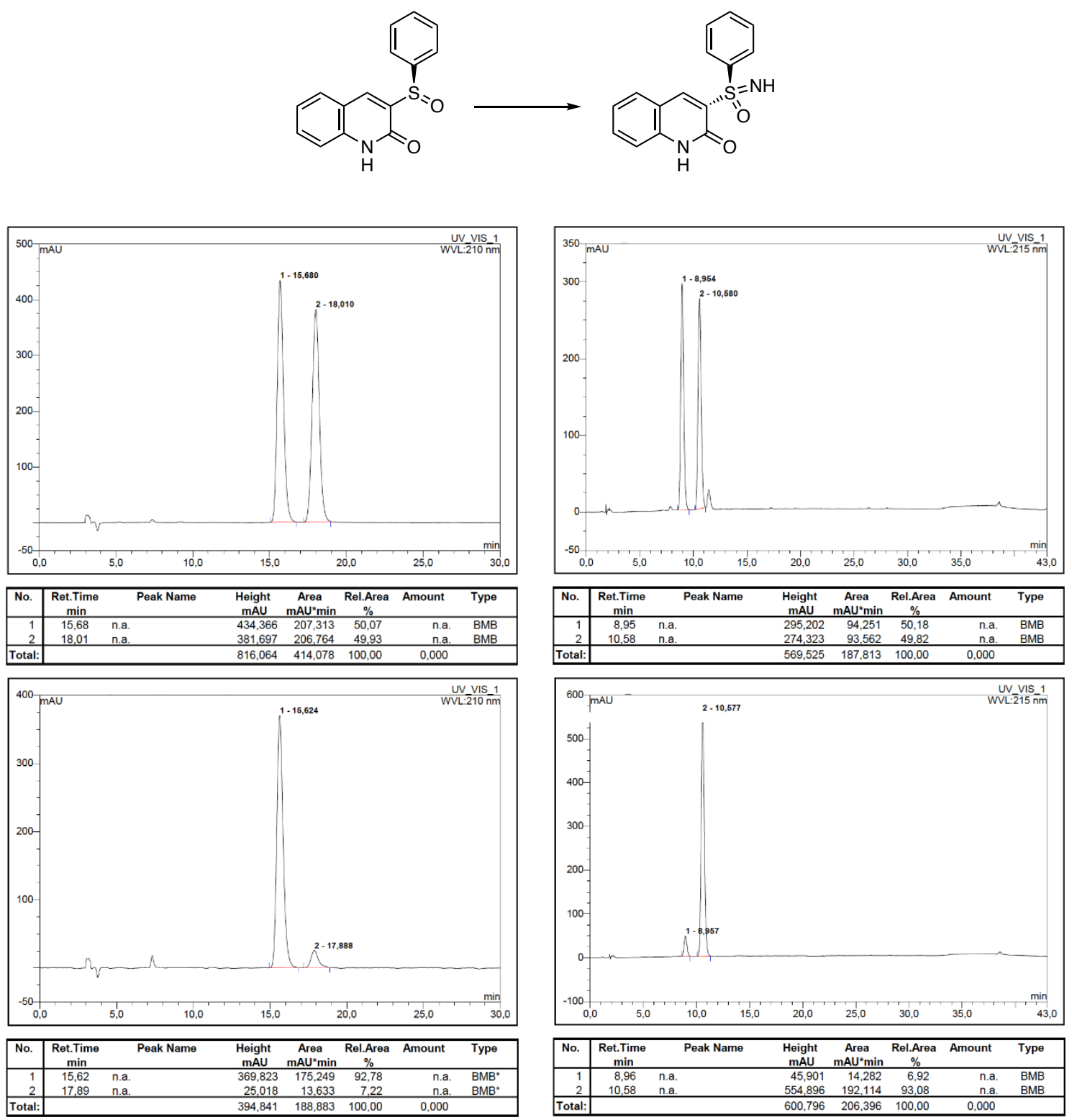

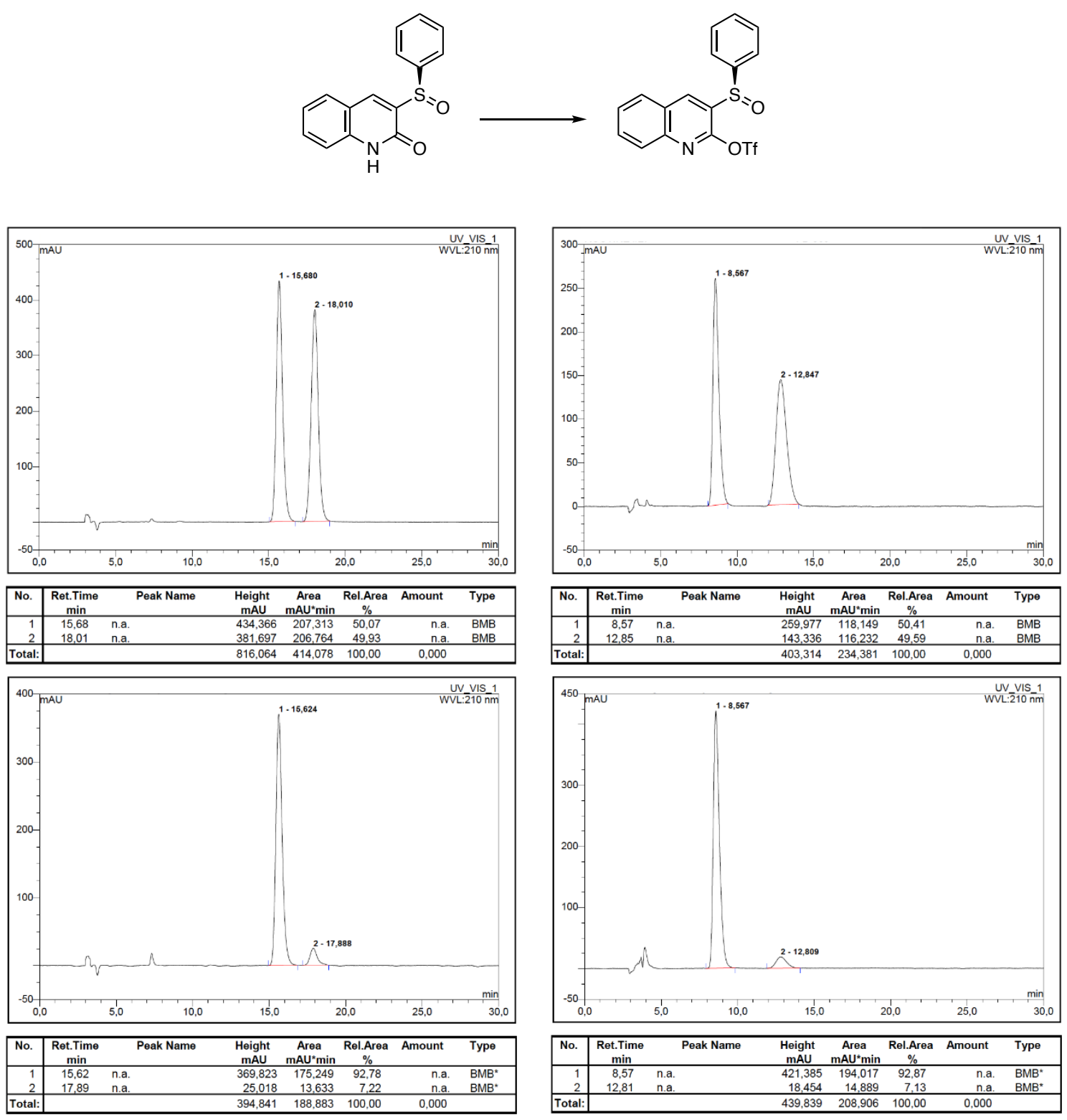

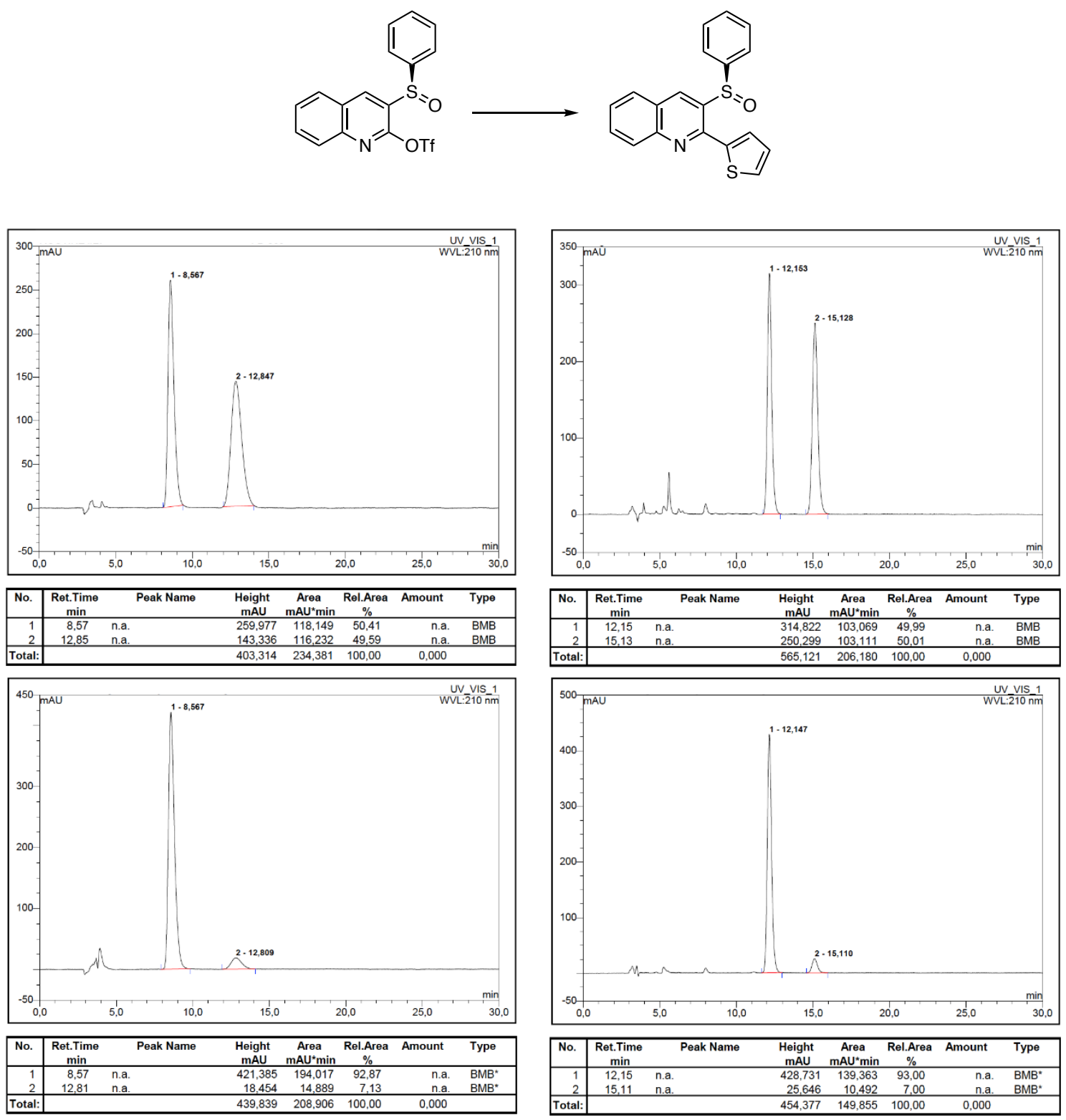

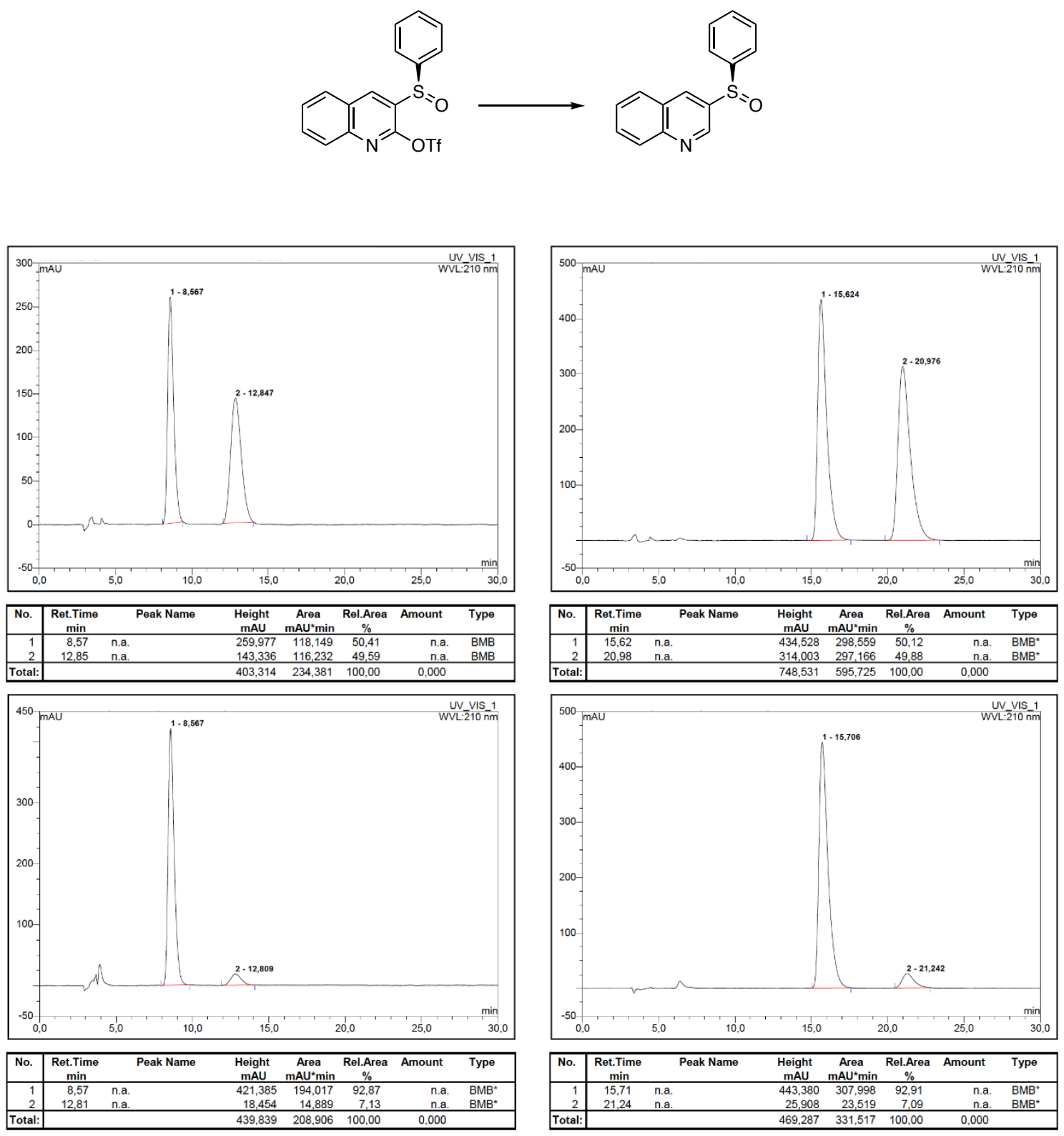

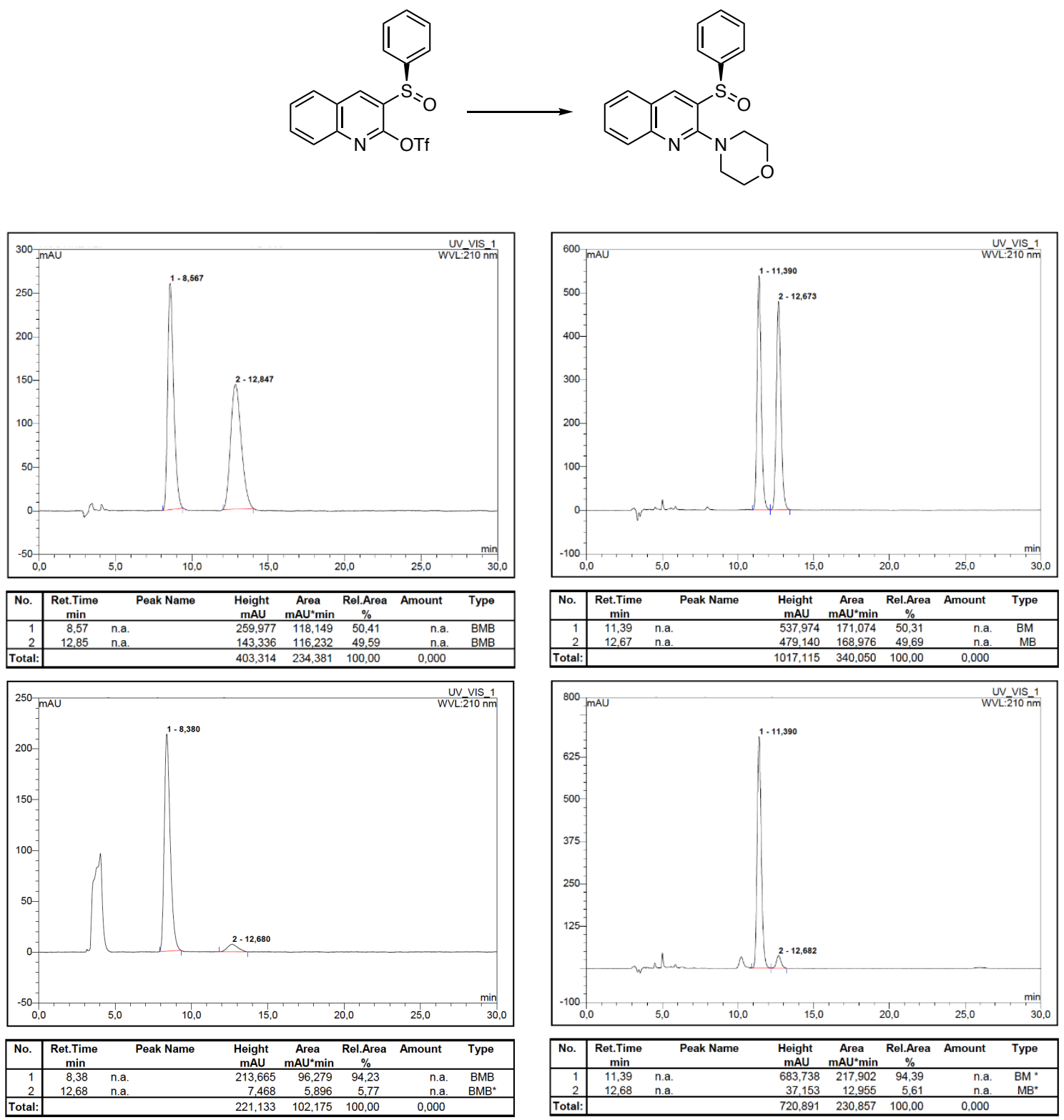

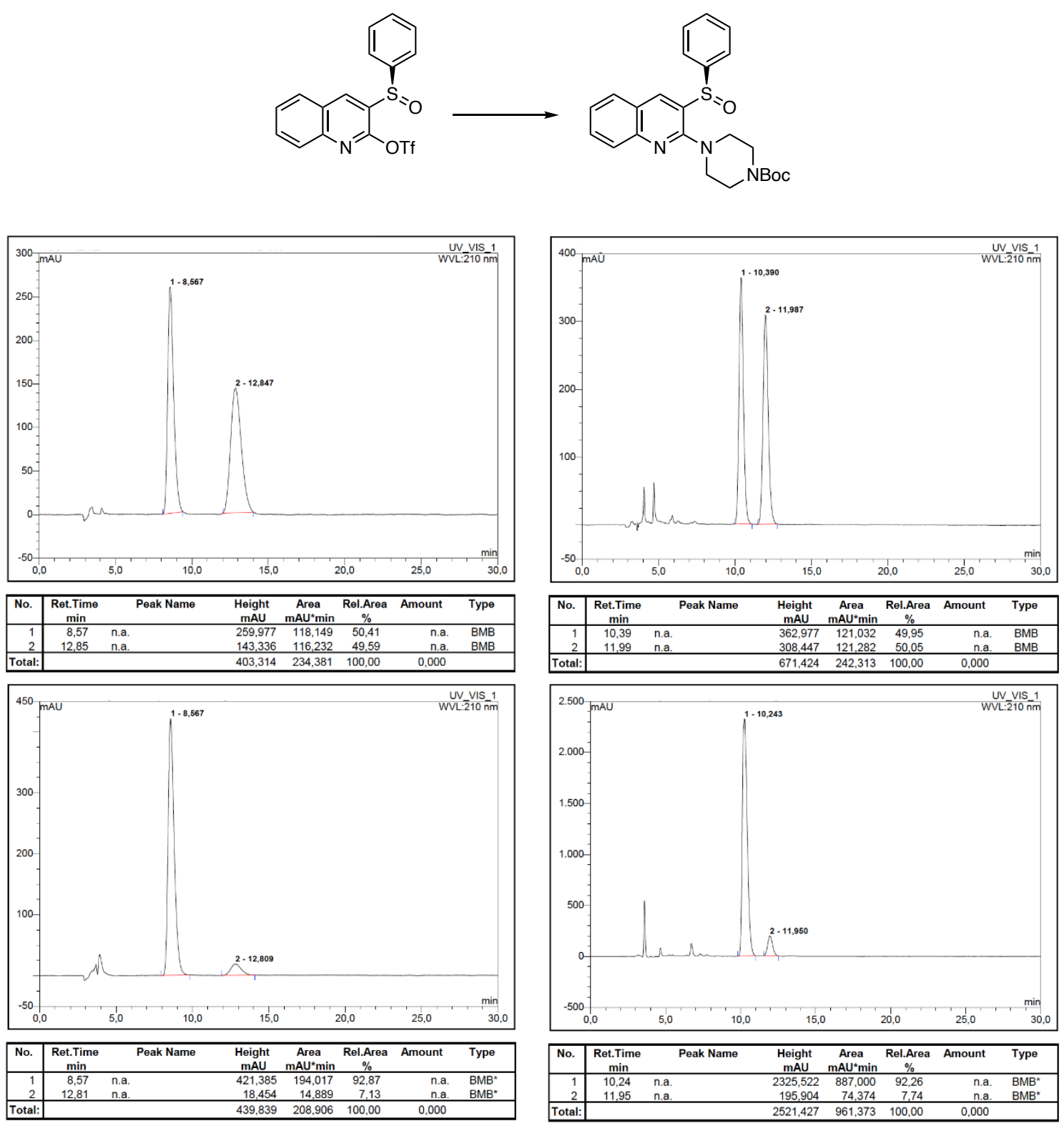


\section{ECD spectroscopic analysis}

\subsection{Absolute configuration of compound 8I via ECD spectroscopy}

Experimental UV and CD spectra were recorded on an Applied Photophysics ChiraScan spectrometer for a $4.7 \times 10^{-5} \mathrm{M}$ solution of $8 \mathrm{I}$ in DMSO ( $1 \mathrm{~cm}$ path length, 5 scans). Geometry optimizations and UV and ECD spectra calculations at B3PW91/6-31+G(3df,2pd)/IEFPCM(DMSO) ${ }^{13}$ level of theory considered two conformers of 8 , which possess a computed energy difference of $\Delta \mathrm{E}_{\text {elec }}=1.27 \mathrm{kcal} / \mathrm{mol}$. Comparison of experimental and computed spectra allows an unambiguous assignment of an $(R)$-configuration at the sulfur atom.
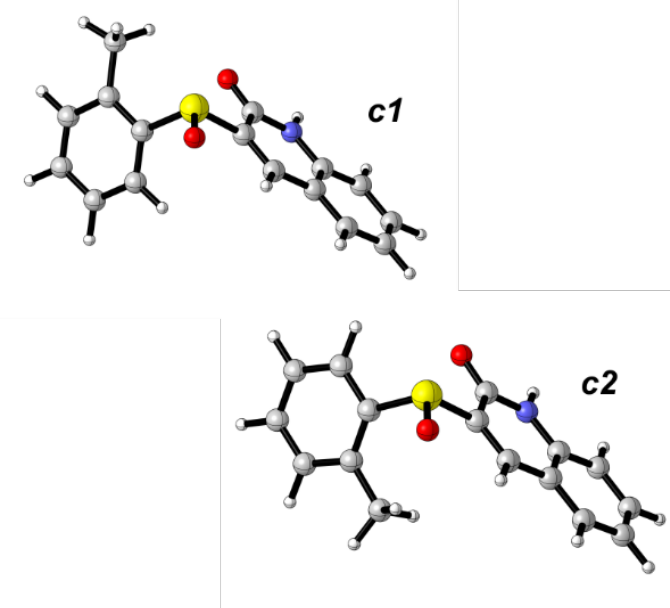

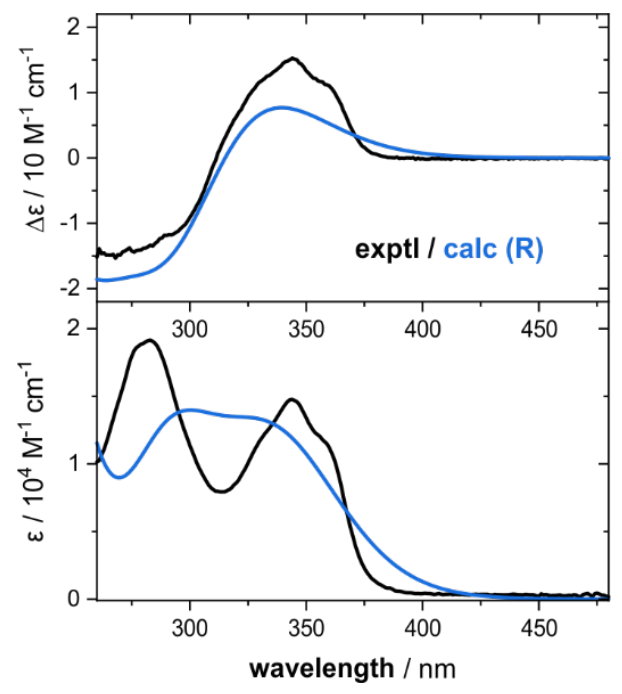

Figure S1: The two conformations of $\mathbf{8} \mathbf{1}$ considered for the spectra calculations and the comparison of experimental and computed UV and CD spectra.

\subsection{Cartesian coordinates of $8 \mid-c 1$ and $-c 2$}

conformer $c 1$

$\begin{array}{llll}\text { N } & -1.76573100 & 1.64854900 & 0.30821300 \\ \text { C } & -0.51954100 & 1.39472700 & -0.21469600 \\ \text { C } & -0.35739900 & 0.04858600 & -0.73902300 \\ \text { C } & -1.36785300 & -0.85375300 & -0.74807000 \\ \text { C } & -2.64582000 & -0.52647000 & -0.19641200 \\ \text { C } & -3.72351300 & -1.43150000 & -0.16937400 \\ \text { C } & -4.93672400 & -1.06241500 & 0.37756200 \\ \text { C } & -5.09725500 & 0.22688900 & 0.90904600 \\ \text { C } & -4.05666900 & 1.13866000 & 0.89535000 \\ \text { C } & -2.82356400 & 0.76706500 & 0.34312100 \\ \text { O } & 0.36282400 & 2.25500600 & -0.22476800 \\ \text { S } & 1.20344900 & -0.34159100 & -1.51996300 \\ \text { C } & 2.24661900 & -0.38120900 & -0.05094100 \\ \text { C } & 1.97185200 & -1.33501000 & 0.92796600\end{array}$

conformer $c 2$

$\begin{array}{cccc}\text { N } & -1.75947500 & 1.74618100 & 0.05404300 \\ \text { C } & -0.51535500 & 1.47113600 & -0.46616100 \\ \text { C } & -0.30482700 & 0.06879400 & -0.79337000 \\ \text { C } & -1.28427100 & -0.85821800 & -0.65939900 \\ \text { C } & -2.56253800 & -0.50643700 & -0.12592100 \\ \text { C } & -3.60238900 & -1.43853700 & 0.05196300 \\ \text { C } & -4.81603400 & -1.04360800 & 0.57926200 \\ \text { C } & -5.01473800 & 0.29860900 & 0.93984000 \\ \text { C } & -4.01212700 & 1.23768500 & 0.77509800 \\ \text { C } & -2.77921100 & 0.84053300 & 0.24041300 \\ \text { O } & 0.31981800 & 2.36115900 & -0.63205900 \\ \text { S } & 1.24042500 & -0.36424300 & -1.58714700 \\ \text { C } & 2.40684900 & -0.11456100 & -0.24075100 \\ \text { C } & 3.36513600 & 0.86283900 & -0.51334900\end{array}$




\begin{tabular}{|c|c|c|c|c|c|c|c|}
\hline C & 2.80756000 & -1.45370200 & 2.03068600 & C & 4.37654300 & 1.12931100 & 0.40250300 \\
\hline C & 3.91422400 & -0.61296100 & 2.14084400 & C & 4.42949600 & 0.39652000 & 1.58387900 \\
\hline $\mathrm{C}$ & 4.18063300 & 0.32994700 & 1.15355600 & C & 3.47865300 & -0.58797800 & 1.84046400 \\
\hline C & 3.35816600 & 0.46982600 & 0.02895700 & C & 2.44199000 & -0.87017500 & 0.94528700 \\
\hline C & 3.67633000 & 1.49939200 & -1.01942600 & C & 1.43586800 & -1.93214100 & 1.28590900 \\
\hline O & 1.06358500 & -1.75458400 & -1.99973100 & 0 & 1.14365800 & -1.82626100 & -1.89709300 \\
\hline $\mathrm{H}$ & -1.89478800 & 2.57884100 & 0.68470100 & $\mathrm{H}$ & -1.92079800 & 2.71629200 & 0.29208100 \\
\hline $\mathrm{H}$ & -1.19840700 & -1.83408900 & -1.18313400 & $\mathrm{H}$ & -1.08812500 & -1.88225300 & -0.96223000 \\
\hline $\mathrm{H}$ & -3.58190800 & -2.42274800 & -0.58496200 & $\mathrm{H}$ & -3.43104900 & -2.47088100 & -0.23126100 \\
\hline $\mathrm{H}$ & -5.76263500 & -1.76259700 & 0.39700900 & $\mathrm{H}$ & -5.61294100 & -1.76415900 & 0.71519400 \\
\hline $\mathrm{H}$ & -6.04947900 & 0.51711500 & 1.33729400 & $\mathrm{H}$ & -5.96714000 & 0.60852000 & 1.35369000 \\
\hline $\mathrm{H}$ & -4.18699700 & 2.13314400 & 1.30608700 & $\mathrm{H}$ & -4.17184000 & 2.27269800 & 1.05438200 \\
\hline $\mathrm{H}$ & 1.11129500 & -1.98550600 & 0.81908500 & $\mathrm{H}$ & 3.31195500 & 1.41277100 & -1.44603300 \\
\hline $\mathrm{H}$ & 2.59737000 & -2.19174000 & 2.79562400 & $\mathrm{H}$ & 5.11690900 & 1.89087100 & 0.18925700 \\
\hline $\mathrm{H}$ & 4.57401900 & -0.69386700 & 2.99714100 & $\mathrm{H}$ & 5.21603200 & 0.58302400 & 2.30613900 \\
\hline $\mathrm{H}$ & 5.04787900 & 0.97447700 & 1.24841300 & $\mathrm{H}$ & 3.53651800 & -1.15902900 & 2.76119400 \\
\hline $\mathrm{H}$ & 4.60307500 & 2.01814400 & -0.77254600 & $\mathrm{H}$ & 1.81234000 & -2.56474000 & 2.09055100 \\
\hline $\mathrm{H}$ & 3.79675800 & 1.04513800 & -2.00622800 & $\mathrm{H}$ & 0.49892100 & -1.48438700 & 1.62914400 \\
\hline $\mathrm{H}$ & 2.87519100 & 2.23750700 & -1.09543600 & $\mathrm{H}$ & 1.20266600 & -2.55592200 & 0.42315700 \\
\hline
\end{tabular}




\section{Abbreviations}

\begin{tabular}{|c|c|}
\hline$A c$ & acetyl \\
\hline aq. & aqueous \\
\hline Boc & tert-butoxycarbonyl \\
\hline $\mathrm{br}$ & broad \\
\hline $\mathrm{Bu}$ & butyl \\
\hline $\mathrm{Bz}$ & benzoyl \\
\hline $\mathrm{C}$ & Celsius \\
\hline calc. & calculated \\
\hline conv. & conversion \\
\hline CPBA & chloroperbenzoic acid \\
\hline$\delta$ & chemical shift \\
\hline $\mathrm{dba}$ & dibenzylideneacetone \\
\hline DCE & dichloroethane \\
\hline DIPEA & $\mathrm{N}, \mathrm{N}$-diisopropylethylamine \\
\hline DMF & $\mathrm{N}, \mathrm{N}$-dimethylformamide \\
\hline DMSO & dimethylsulfoxide \\
\hline ECD & electronic circular dichroism \\
\hline$e e$ & enantiomeric excess \\
\hline ESI & electrospray ionization \\
\hline Et & ethyl \\
\hline equiv & equivalents \\
\hline FCC & flash column chromatography \\
\hline FTIR & fourier transformed infrared spectroscopy \\
\hline g & gram \\
\hline $\mathrm{h}$ & hour(s) \\
\hline HFIP & hexafluoroisopropanol \\
\hline HPLC & high performance liquid chromatography \\
\hline $\mathrm{HR}$ & high resolution \\
\hline $\mathrm{Hz}$ & hertz \\
\hline$i$ & iso \\
\hline IR & infrared \\
\hline J & coupling constant \\
\hline $\mathrm{L}$ & liter \\
\hline$\mu$ & micro \\
\hline $\mathrm{m}$ & milli, meter, multiplet \\
\hline$m$ & meta \\
\hline M & molar \\
\hline $\mathrm{M}$ & metal \\
\hline m.p. & melting point \\
\hline $\mathrm{Me}$ & methyl \\
\hline $\min$ & minute(s) \\
\hline MS & mass spectrometry \\
\hline NMR & nuclear magnetic resonance \\
\hline 0 & ortho \\
\hline$p$ & para \\
\hline $\mathrm{Ph}$ & phenyl \\
\hline phen & 1,10-phenanthroline \\
\hline ppm & parts per million \\
\hline
\end{tabular}




$\begin{array}{ll}\text { Pr } & \text { propyl } \\ \mathrm{q} & \text { quartet } \\ R_{\mathrm{f}} & \text { retardation factor } \\ \mathrm{S} & \text { singlet } \\ \text { sat } & \text { saturated } \\ \text { solv. } & \text { solvent } \\ \mathrm{t} & \text { triplet, time } \\ t & \text { tert } \\ \mathrm{T} & \text { temperature } \\ \mathrm{t}_{\mathrm{R}} & \text { retention time } \\ \text { Tf } & \text { trifluoromethanesulfonyl } \\ \text { THF } & \text { tetrahydrofuran } \\ \text { TLC } & \text { thin layer chromatography } \\ \text { TMEDA } & N, N, N^{\prime}, N^{\prime} \text {-tetramethylenediamine } \\ \text { UV } & \text { ultra-violet } \\ \text { virt } & \text { virtual } \\ \text { Xantphos } & 4,5 \text {-Bis(diphenylphosphino)-9,9-dimethylxanthene }\end{array}$




\section{References}

(1) Saltzmann, H.; Sharefkin, J. G., lodosobenzene. Org. Synth. 1963, 43, 60.

(2) (a) Fackler, P.; Berthold, C.; Voss, F.; Bach, T., Hydrogen-Bond-Mediated Enantio- and Regioselectivity in a Ru-Catalyzed Epoxidation Reaction. J. Am. Chem. Soc. 2010, 132, 15911-15913; (b) Frost, J. R.; Huber, S. M.; Breitenlechner, S.; Bannwarth, C.; Bach, T., Enantiotopos-Selective C-H Oxygenation Catalyzed by a Supramolecular Ruthenium Complex. Angew. Chem. Int. Ed. 2015, 54, 691-695; (c) Burg, F.; Gicquel, M.; Breitenlechner, S.; Pöthig, A.; Bach, T., Site- and Enantioselective C-H Oxygenation Catalyzed by a Chiral Manganese Porphyrin Complex with a Remote Binding Site. Angew. Chem. Int. Ed. 2018, 57, 2953-2957.

(3) Tröster, A.; Alonso, R.; Bauer, A.; Bach, T., Enantioselective Intermolecular [2 + 2] Photocycloaddition Reactions of 2(1H)-Quinolones Induced by Visible Light Irradiation. J. Am. Chem. Soc. 2016, 138, 7808-7811.

(4) Itoh, T.; Mase, T., A General Palladium-Catalyzed Coupling of Aryl Bromides/Triflates and Thiols. Org. Lett. 2004, 6, 4587-4590.

(5) Rubino, M. T.; Agamennone, M.; Campestre, C.; Campiglia, P.; Cremasco, V.; Faccio, R.; Laghezza, A.; Loiodice, F.; Maggi, D.; Panza, E.; Rossello, A.; Tortorella, P., Biphenyl Sulfonylamino Methyl Bisphosphonic Acids as Inhibitors of Matrix Metalloproteinases and Bone Resorption. ChemMedChem 2011, 6, 1258-1268.

(6) Sabol, M. R.; Owen, J. M.; Erickson, W. R., A Novel and Efficient Synthesis of 2,3-Dichloroquinoline. Synthetic Commun. 2000, 30, 427-432.

(7) Peng, J.-B.; Chen, B.; Qi, X.; Ying, J.; Wu, X.-F., Palladium-catalyzed synthesis of quinolin-2(1H)-ones: the unexpected reactivity of azodicarboxylate. Org. Biomol. Chem. 2018, 16, 1632-1635.

(8) Mashraqui, S. H.; Vashi, D.; Mistry, H. D., Efficient Synthesis of 3-Substituted Coumarins. Synthetic Commun. 2004, 34, 3129-3134.

(9) Burg, F.; Breitenlechner, S.; Jandl, C.; Bach, T., Enantioselective oxygenation of exocyclic methylene groups by a manganese porphyrin catalyst with a chiral recognition site. Chemical Science 2020, 11, 2121-2129.

(10) Ahn, B. H.; Lee, I. Y.; Lim, H. N., Step-economical synthesis of 3-amido-2-quinolones by dendritic copper powder-mediated one-pot reaction. Org. Biomol. Chem. 2018, 16, 7851-7860.

(11) Liu, J.; Wu, K.; Shen, T.; Liang, Y.; Zou, M.; Zhu, Y.; Li, X.; Li, X.; Jiao, N., Fe-Catalyzed Amination of (Hetero)Arenes with a Redox-Active Aminating Reagent under Mild Conditions. Chem. Eur J. 2017, 23, 563-567.

(12) Cacchi, S.; Carangio, A.; Fabrizi, G.; Moro, L.; Pace, P., A Convenient Synthesis of Nitrogen-Containing Heterocycles Bearing Amino Substituents from Heteroaryl Triflates. Synlett 1997, 12, 1400-1402.

(13) Frisch, M. J.; Trucks, G. W.; Schlegel, H. B.; Scuseria, G. E.; Robb, M. A.; Cheeseman, J. R.; Scalmani, G.; Barone, V.; Mennucci, B.; Petersson, G. A.; Nakatsuji, H.; Caricato, M.; Li, X.; Hratchian, H. P.; Izmaylov, A. F.; Bloino, J.; Zheng, G.; Sonnenberg, J. L.; Hada, M.; Ehara, M.; Toyota, K.; Fukuda, R.; Hasegawa, J.; Ishida, M.; Nakajima, T.; Honda, Y.; Kitao, O.; Nakai, H.; Vreven, T.; Montgomery, J. J. A.; Peralta, J. E.; Ogliaro, F.; Bearpark, M.; Heyd, J. J.; Brothers, E.; Kudin, K. N.; Staroverov, V. N.; T. Keith, R. K.; Normand, J.; Raghavachari, K.; Rendell, A.; Burant, J. C.; Iyengar, S. S.; Tomasi, J.; Cossi, M.; Rega, N.; Millam, J. M.; Klene, M.; Knox, J. E.; Cross, J. B.; Bakken, V.; Adamo, C.; Jaramillo, J.; Gomperts, R.; Stratmann, R. E.; Yazyev, O.; Austin, A. J.; Cammi, R.; Pomelli, C.; Ochterski, J. W.; Martin, R. L.; Morokuma, K.; Zakrzewski, V. G.; Voth, G. A.; Salvador, P.; Dannenberg, J. J.; Dapprich, S.; Daniels, A. D.; Farkas, O.; Foresman, J. B.; Ortiz, J. V.; Cioslowski, J.; Fox, D. J., Gaussian 09, Rev E.01 2013, Wallingford CT, USA. 